GUSTAVO SIEBERT

CARACTERIZAÇÃO DO DESEMPENHO TRIBOLÓGICO DE FERROS FUNDIDOS UTILIZADOS NA FABRICAÇÃO DE BLOCOS DE MOTORES DE COMBUSTÃO INTERNA 
GUSTAVO SIEBERT

\section{CARACTERIZAÇÃO DO DESEMPENHO TRIBOLÓGICO DE FERROS FUNDIDOS UTILIZADOS NA FABRICAÇÃO DE BLOCOS DE MOTORES DE COMBUSTÃO INTERNA}

Tese apresentada à Escola Politécnica da Universidade de São Paulo para obtenção do título de Doutor em Ciências

Área de Concentração: Engenharia Mecânica de Projeto e Fabricação

Orientador: Prof. Dr. Amilton Sinatora 
Autorizo a reproduçāo e divulgação total ou parcial deste trabalho, por qualquer meio convencional ou eletrônico, para fins de estudo e pesquisa, desde que citada a fonte.

Este exemplar foi revisado e corrigido em relaçâo à versăo original, sob responsabilidade única do autor e com a anuência de seu orientador.

Såo Paulo, 02 de Jutho de 2021

Assinatura do autor:

Assinatura do orientador:

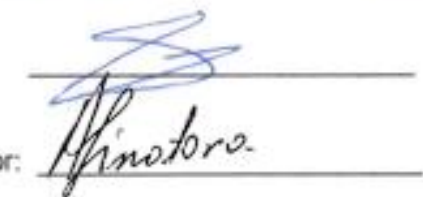

\section{Siebert, Gustavo}

CARACTERIZAČÃO DO DESEMPENHO TRIBOLÓGICO DE FERROS

FUNDIDOS UTILIZADOS NA FABRICAÇÃO DE BLOCOS DE MOTORES DE

COMBUSTÃO INTERNA / G. Siebert -- versão corr. -- São Paulo, 2021.

$153 \mathrm{p}$.

Tese (Doutorado) - Escola Politécnica da Universidade de Såo Paulo. Departamento de Engenharia Mecânica.

1.Grafita 2.Tribofilme 3.Triboteste 4.Ferro fundido cinzento 5.Ferro fundido vermicular I.Universidade de Săo Paulo. Escola Politécnica.

Departamento de Engenharia Mecânica II.t. 


\section{AGRADECIMENTOS}

Dedico este trabalho, principalmente aos meus pais, Antonio e Irani, à minha esposa, Camila e a minha filha Ceci. Meus pais me deram tudo que eu precisei para trilhar o caminho que eu escolhi. A minha esposa está sempre ao meu lado, me tornando mais forte para continuar neste caminho e a minha filha que faz com que eu queira ser sempre uma pessoa melhor.

Agradeço também aos meus irmãos, Carlos Henrique e Manuela. Buscar merecer o orgulho deles me faz superar todos os desafios que se apresentam.

Dedico um agradecimento especial ao Prof. Dr. Wilson Luiz Guesser, que infelizmente nos deixou antes da conclusão deste trabalho, por toda a sua contribuição para a geração de conhecimento sobre ferros fundidos e por ser mentor e idealizador deste doutorado. A sua falta sempre será sentida na comunidade científica e ainda mais na Tupy, empresa para a qual dedicou praticamente uma vida de trabalho.

Agradeço ao Prof. Dr. Amilton Sinatora por orientar este trabalho e me dar a oportunidade do seu convívio durante este período. Eu aproveitei ao máximo cada minuto de conversa e me tornei muito melhor com todo o conhecimento adquirido.

À Tupy pela oportunidade que me foi dada e os recursos que foram investidos neste trabalho. Agradeço à Luiz Carlos Guedes que criou, junto com o Guesser, o grupo de pesquisadores do qual fiz parte e que continha este trabalho de doutorado.

Aos demais integrantes do grupo de pesquisa, Rafael, Felipe e Renato, pela companhia e apoio nesta jornada. Aos professores do LFS, Izabel, Roberto, Tanaka, Rodrigo e Francisco. À todos os pesquisadores que passaram pelo LFS durante o período do meu doutorado, em especial à Marcos Ara, Franco, Sebastian, Juan, Paulo, Gustavo Tressia, Alexander Zuleta, André Zuin, Ana Júlia, Iramar e Pablo que mantiveram o ambiente com um elevado nível de conhecimento e cultura, além de ajudar sempre que precisei.

Ao incansável Prof. Tiago Cousseau que sempre esteve muito próximo deste trabalho e que com certeza terá uma carreira brilhante pela frente. À todos os técnicos do LFS, Rodnei, Carlos, Cássio, Rafael, Rafael Nobre e Fábio, com quem tive o imenso prazer de trabalhar. Todos fazem um trabalho de qualidade inquestionável e são sempre solícitos. 
Ao técnico do laboratório de metalografia da Tupy, Geraldo Luiz, pela valiosa ajuda na fabricação das amostras.

Por último, agradeço às minhas duas avós. Elas, infelizmente, não estarão presentes quando eu me tornar doutor. Mas, tenho certeza que estão muito orgulhosas e olhando por mim de onde estão. 


\section{RESUMO}

\section{SIEBERT, G. Caracterização do desempenho tribológico de ferros fundidos} utilizados na fabricação de motores de combustão interna. Tese (Doutorado), Escola Politécnica, Universidade de São Paulo, São Paulo, 2021.

Este trabalho se propõe, principalmente, a avaliar as diferenças de desempenho tribológico entre ferro fundido cinzento e ferro fundido vermicular em tribotestes que simulam o ponto morto superior de um motor de combustão interna e determinar qual deles tem o melhor desempenho tribológico. Para isto, foram utilizados um ferro fundido cinzento (FC) classe ASTM 25 e um ferro fundido vermicular (FV) classe ISO GJV 450. As amostras utilizadas nos tribotestes foram retiradas de blocos de motores e possuem a superfície gerada por brunimento de platô. Estas amostras foram submetidas a ensaios em tribômetro (SRV-4) que simularam o ponto morto superior de um motor de combustão interna em condição de abundância de óleo (amostras submersas) e de quantidade limitada de óleo (ensaios com apenas uma gota). Foram utilizadas técnicas de interferometria ótica, microscopia eletrônica de varredura, espectroscopia Raman e microdureza Vickers para caracterizar as superfícies das amostras antes e depois dos ensaios com o objetivo de determinar as diferenças entre os materiais e descrever alguns dos fenômenos tribológicos que envolvem o sistema anel/cilindro. Os resultados mostraram que quando as amostras são ensaiadas completamente submersas em óleo, fazendo com o que o tribossistema tenha uma oferta de aditivos praticamente ilimitada, a influência do tipo de ferro fundido no desempenho do tribossistema é indetectável pelos métodos utilizados neste trabalho. Isto ocorre porque o tribofilme gerado a partir dos aditivos do óleo é que determina o desempenho do tribossistema e não foram detectadas diferenças entre o tribofilme gerado na trilha de desgaste das amostras de FC e FV. Em ambas as amostras foi formado um filme de ZDDP (dialquilditiofosfato de zinco) recoberto com $\mathrm{MoS}_{2}$, que é resultado da ativação do MoDTC (Dialquiditiocarbamato de Molibdênio). Quando as amostras foram avaliadas com apenas uma gota de óleo, aumentando a severidade do ensaio para avaliar a resistência ao "scuffing" do tribossistema, as amostras de ferro fundido cinzento não suportaram o ensaio de uma hora enquanto as amostras de ferro fundido vermicular chegaram até o final do 
ensaio, mostrando que o segundo possui maior resistência ao "scuffing" que o primeiro. O comportamento do coeficiente de atrito foi bastante diferente do observado nos ensaios realizados com a amostra submersa em óleo e não houve ativação do MoDTC (dialquilditiocarbamato de molibdênio) nos ensaios com apenas uma gota de óleo, mostrando que a quantidade de óleo tem influência na formação do tribofilme. A grafita teve papel fundamental nesta condição de ensaio com apenas uma gota de óleo. Ela atuou antes que os aditivos do óleo reagissem com a superfície e formassem um tribofilme e quando a quantidade de aditivos foi pequena ela foi a grande responsável pela resistência ao scuffing do tribossistema. A grafita vermicular, devido a sua morfologia e a forma como é extrudada para a superfície, proporciona um tribofilme com maior capacidade de carga e durabilidade do que o gerado pela grafita lamelar. Por isto, o ferro fundido vermicular apresenta maior resistência ao scuffing do que o cinzento e pode ser considerado como tendo maior potencial para aplicação e motores de combustão interna, principalmente naqueles que possuem pressão de combustão elevada.

Palavras-chave: ferro fundido cinzento, ferro fundido vermicular, tribofilme, MoDTC, grafita, triboteste. 


\begin{abstract}
SIEBERT, G. Tribological performance characterization of cast irons used in cylinder blocks of internal combustion engines. Thesis (Doctorate), Escola Politécnica, Universidade de São Paulo, São Paulo, 2020.
\end{abstract}

This work aims to study the performance differences between gray cast iron and compacted graphite iron when submitted to tribotests that simulate the top dead center of an internal combustion engine and to define which one has the best tribological performance. To execute this study a gray cast iron (FC), class ASTM 25, and a compacted graphite iron (FV), class ISO GJV 450, were used. The samples used for the tribotests were cut from cylinder blocks and their surfaces are plateau honed. These samples were tested in tribometer (SRV-4) that simulates the top dead center of an internal combustion engine in lubrication conditions of fully flooded (samples submerged in oil) and starvation (only one drop of oil on the surface). The samples were characterized using laser interferometry, scanning electron microscopy (SEM), Raman spectroscopy and Vickers microhardness tests before and after the tribotest to define the differences between the cast irons and describe some tribological phenomena of the cylinder/ring tribosystem. The results revealed that tribofilm, formed from the oil additives, rules the tribological behavior of the tribosystem when the samples were tested fully flooded and the tribofilm formed on the gray cast iron is the same of the one formed on compacted graphite iron samples. As a result, the type of the cast iron has no influence on the tribological performance in this condition. The tribofilm of both type of samples is constituted of a ZDDP (Zinc Dialkyl Dithiophosphate) film covered by MoS2, which is the result of MoDTC (molybdenum dithiocarbamate) activation. On the other hand, when the samples were tested with only one drop of oil to evaluate its resistance to scuffing, the gray cast iron didn't withstand the test of one hour, but the compacted graphite iron samples achieved the end of the test with no scuffing occurrence. It means that compacted graphite iron has better scuffing resistance than gray cast iron in the tested conditions. The friction coefficient behavior was also different between the tests fully flooded and those with only one drop of oil, mostly because in the second condition there wasn't MoDTC activation. It shows that the amount of oil has great 
influence in the tribofilm formation from oil additives. The graphite has great importance in a starvation condition of lubrication condition, being the main responsible for scuffing resistance. The compacted graphite, due to its morphology and extrusion behavior, provides a tribofilm with greater load capacity and durability than the tribofilm provided by lamellar graphite. Consequently, the compacted graphite iron has greater scuffing resistance than the gray cast iron and can be considered a better choice for cylinder blocks of internal combustion engines, especially for those with high combustion pressure.

Key words: gray cast iron, compacted graphite iron, tribofilm, MoDTC, graphite, tribotest. 


\section{LISTA DE FIGURAS}

Figura 1 - Estimativa de como a energia obtida do combustível é dissipada em cada sistema para manter um carro rodando a uma velocidade de $60 \mathrm{~km} / \mathrm{h}$ [3] .

Figura 2 - Efeito da velocidade do veículo na contribuição de cada subsistema no total de atrito dissipado em um motor de combustão interna [1] ..........................

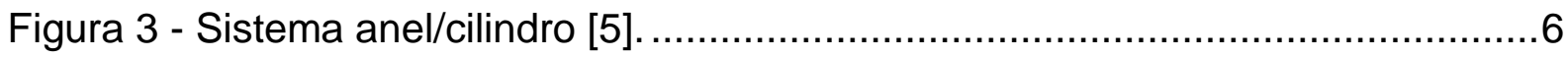

Figura 4 - Superfície típica de um cilindro gerado através do brunimento de platô [86].

Figura 5 - Curva de Stribeck mostrando os regimes de lubrificação experimentados pelo sistema anel/cilindro e outros sistemas tribológicos do

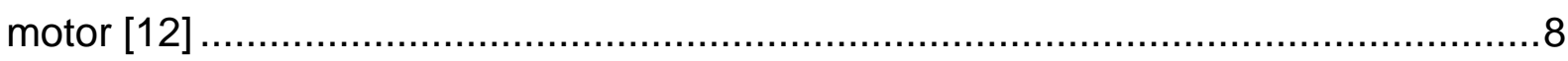

Figura 6 - Classificação dos aditivos segundo a sua atuação [13] ........................10

Figura 7 - Molécula de ZDDP e seus radicais. .......................................................11

Figura 8 - Diagrama esquemático da estrutura e da composição do tribofilme

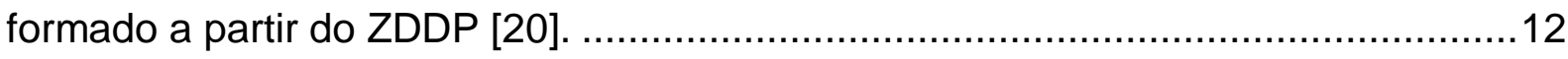

Figura 9 - Exemplos de modificadores de atrito orgânicos.....................................15

Figura 10 - representação gráfica do mecanismo de lubrificação por monocamada do ácido carboxílico [16].

Figura 11 - Comportamento do atrito nas primeiras 10 rotações em um teste de baixa velocidade na configuração esfera sobre disco. Soluções em hexadecano

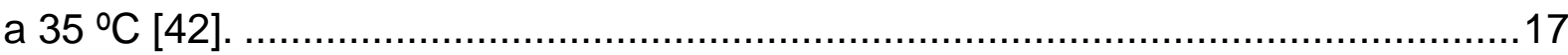

Figura 12 - Molécula de dialquilditiocarbamato de molibdênio [50] .........................18

Figura 13 - Redução do atrito por dois MoDTCs diferentes [31, 51] ......................19

Figura 14 - Etapas para decomposição do MoDTC em MoS 2 [52] a) transferência de elétrons das ligações químicas Mo-S. b) formação de radicais livres. c) recombinação dos radicais promovendo a formação do dissulfeto de tiuram, enquanto o outro radical se decompõe em MoS2 e MoO2.

Figura 15 - Mecanismo de formação do $\mathrm{MoS}_{2}$ a partir do MoDTC proposto por Khaemba et al. [70].

Figura 16 - Processo de geração da superfície nascente durante o deslizamento [55]. 
Figura 17 - Formação de filme espesso a partir de ácidos graxos, também chamado por Stachowiak de camada de sabão [16].

Figura 18 - Comparação da atividade superficial do alumínio e do níquel para componentes orgânicos. 1 - benzeno, 2 - etanol, 3 - n-butil éter, 4 - sec-butil éter, 5 - acetone, 6 - sulfeto de etila [55].

Figura 19 - Composição química da trilha de desgaste de um ferro fundido rico em fósforo, com steadita na sua microestrutura. $\mathrm{Na}$ figura (a) uma foto de microscopia ótica de uma região com carbonetos e steadita (regiões mais claras). Figura (b) é uma imagem de MEV indicando os pontos onde foram registrados os espectros de EDS. O espectro 1 foi registrado fora da área da steadita e mostra uma região rica em elementos presentes nos aditivos de óleo ( $\mathrm{Zn}, \mathrm{P}, \mathrm{S}$ e $\mathrm{Ca}$ ). O espectro 2 foi registrado em cima do carboneto e não detectado nenhum elemento do aditivo neste ponto. $O$ espectro 3 foi colhido na região da esteadita e também não detectou a presença de elementos dos aditivos.

Figura 20 - Energia dissipadas por ciclo em um ensaio esfera contra plano para a ativação do ZDDP em superfícies fresadas (Sup.2) e retificadas (Sup.4) [71].

Figura 21 - Curvas de atrito de ensaios esfera contra disco lubrificados com óleo totalmente formulado 5W30. Gráfico A apresenta os ensaios com discos lisos $(\mathrm{Sa}=0,05)$ e o gráfico $\mathrm{B}$ os ensaios com discos rugosos $(\mathrm{Sa}=0,28)[26] \ldots \ldots .29$ Figura 22 - Classificação dos diferentes tipos de tribotestes de acordo com a norma DIN 50322 (1979) [72]...

Figura 23 - Mecanismo de lubrificação sólida. As lamelas da grafita cisalham umas sobre as outras sob força de atrito. $O$ baixo coeficiente de atrito aparece ao longo do plano basal sob tensões de cisalhamento [86].

Figura 24 - Espectro Raman da grafita [adaptado de 7]

Figura 25 - a) grafita lamelar [90], b) grafita nodular [90], c) grafita vermicular [91]

Figura 26 - Estrutura cristalográfica da grafita [92]

Figura 27 - Imagem obtida usando um MEV de uma de uma vermicular com ataque profundo de um Ferro fundido com $0,013 \%$ de magnésio. As setas indicam agregados com diferentes orientações formando uma grafita vermicular [89]. 
Figura 28 - Extrusão da grafita de uma amostra de ferro fundido cinzento devido a carga aplicada por uma indentação próxima ao veio [96]

Figura 29 - Resistência ao desgaste de ferros fundidos nodulares e cinzentos medidas usando um ensaio de pino sobre disco à seco usando dois níveis de carga e variando a velocidade [102].

Figura 30 - Seção transversal de uma amostra de ferro fundido cinzento testado em um regime de desgaste moderado mostrando a região onde uma porção de material foi arrancada por influência da grafita. [97]

Figura 31 - Imagem ilustrativa da posição de retirada das amostras.

Figura 32 - Dimensões das amostras para ensaios em tribômetro usadas neste trabalho.

Figura 33 - Microestrutura das amostras de FC. Ataque realizado com nital 3\%.....54 Figura 34 - Microestrutura das amostras de FV. Ataque realizado com nital 3\%.....55 Figura 35 - Tratamentos feitos na imagem antes da retirada dos perfis utilizados para o cálculo dos parâmetros de Greenwood e Williamson.

Figura 36 - Interface do programa Summits usado para extrair os parâmetros de Greenwood e Williamson de um perfil de rugosidade [109].

Figura 37 - À esquerda uma imagem de uma parte da trilha de desgaste feita com 3 medições no sentido transversal ao risco por uma medição no sentido do risco e à direita uma montagem com 11 medições 3 por 1 reconstruindo completamente a trilha de desgaste.

Figura 38 - Perfil médio de uma trilha de desgaste $(A)$ e área da trilha de desgaste medida através do perfil médio (B).

Figura 39 - Configuração do teste de anel contra cilindro executado na SRV-4, mostrando a aplicação da carga, direção do deslizamento e área de contato conforme que esta configuração gera.

Figura 40 - Amostra submersa em óleo à esquerda e amostra com apenas uma gota de nas uma gota de óleo à direita.

Figura 41 - Microdureza (HV 0,01) dos microsconstituintes das matrizes do FV e FV.

Figura 42 - Espectros Raman de uma grafita nodular, uma lamelar e uma vermicular. 
Figura 43 - Dureza da superfície das amostras FC e FV fora da trilha de desgaste.

Figura 44 - Dureza da superfície das amostras FC e FV dentro da trilha de desgaste.

Figura 45 - Imagem de MEV da superfície de uma amostra de FC com a identificação das regiões de fenda e platô.

Figura 46 - Deformação da matriz do FC sobre grafitas que afloram a superfície formando as fendas.

Figura 47 - Espectros Raman registrados nas fendas das amostras de FC (tons de azul) e FV (tons de vermelho).

Figura 48 - Espectros Raman registrados nos platôs das amostras de FC (tons de azul) e FV (tons de vermelho).

Figura 49 - Espectros registrados dentro da trilha de desgaste da amostra de FC (tons de azul) e FV (tons de vermelho)

Figura 50 - Espectros registrados fora da trilha de desgaste da amostra de FC (tons de azul) e FV (tons de vermelho)

Figura 51 - Superfícies das amostras FC (à esquerda) e FV (à direita) antes dos tribotestes.

Figura 52 - Superfícies das amostras de FC (à esquerda) e FV (à direita) dentro da trilha de desgaste após o triboteste.

Figura 53 - Superfície da amostra Vs2 após o triboteste. Os círculos vermelhos indicam crateras, possivelmente geradas pelo mecanismo de desgaste de fadiga de contato.

Figura 54 - Imagens do centro da trilha de desgaste das amostras de FC (à esquerda) e FV (à direita) geradas por interferometria ótica.

Figura 55 - Gráficos com os valores médios de $Z_{s}, \beta_{s}$ e $\eta$ e seus respectivos desvios padrão antes dos tribotestes.

Figura 56 - Gráficos com os valores médios de Zs, $\beta$ s e $\eta$ e seus respectivos desvios padrão depois dos triboteste e dentro da trilha de desgaste.

Figura 57 - Coeficiente de atrito registrado pela SRV para as amostras de ferro fundido cinzento (curvas azuis) Cs1, Cs2 e Cs3 e para as amostras de ferro fundido vermicular (curvas vermelhas) Vs1, Vs2 e Vs3. 
Figura 58 - Coeficiente de atrito registrado pela SRV para as amostras de ferro fundido cinzento (curvas azuis) Cs1, Cs2 e Cs3 e para as amostras de ferro fundido vermicular (curvas vermelhas) Vs1, Vs2 e Vs3. Ampliado nos primeiros 600 segundos de ensaio.

Figura 59 - À esquerda, superfície próxima ao ponto morto superior do cilindro após um ensaio de durabilidade [12]. À direita a superfície da amostra Cs1 após o ensaios em tribômetro.

Figura 60 - Tempo de ativação versus desgaste.

Figura 61 - Dureza da superfície das amostras FC e FV fora da trilha de desgaste.

Figura 62 - Dureza da superfície das amostras FC e FV dentro da trilha de desgaste.

Figura 63 - Espectros Raman registrados nas fendas das amostras de FC (tons de azul) e FV (tons de vermelho).

Figura 64 - Espectros Raman registrados nos platôs das amostras de FC (tons de azul) e FV (tons de vermelho).

Figura 65 - Espectros registrados dentro da trilha de desgaste da amostra de FC (tons de azul) e FV (tons de vermelho).

Figura 66 - Diferença de intensidade da banda G do espectro da grafita para as amostras de FC (azul) e FV (vermelho) após os tribotestes.

Figura 67 - Superfícies das amostras FC (à esquerda) e FV (à direita) antes dos tribotestes.

Figura 68 - Superfícies das amostras de FC (à esquerda) e FV (à direita) dentro da trilha de desgaste após o triboteste.

Figura 69 - Superfícies das amostras de FC (à esquerda) e FV (à direita) dentro da trilha de desgaste após o triboteste com as crateras identificadas em vermelho.

Figura 70 - Imagens do centro da trilha de desgaste das amostras de FC (à esquerda) e FV (à direita) geradas por interferometria ótica.

Figura 71 - Coeficiente de atrito registrado pela SRV para as amostras de ferro fundido cinzento (curvas azuis) $\mathrm{Cg} 1$ e $\mathrm{Cg} 2$ e para as amostras de ferro fundido vermicular (curvas vermelhas) $\mathrm{Vg} 1 \mathrm{e} \mathrm{Vg} 2$. 
Figura 72 - Dureza da superfície das amostras FC e FV fora da trilha de desgaste.

Figura 73 - Dureza da superfície das amostras FC e FV dentro da trilha de desgaste.

Figura 74 - Espectros Raman registrados nas fendas das amostras de FC (tons de azul) e FV (tons de vermelho).

Figura 75 - Espectros Raman registrados nos platôs das amostras de FC (tons de azul) e FV (tons de vermelho).

Figura 76 - Espectros registrados dentro da trilha de desgaste das amostras de FC (azul) e FV (vermelho) dos ensaios interrompidos com 5 minutos.

Figura 77 - Espectros registrados nas trilhas de desgaste das amostras de FC e FV testadas por 6 minutos com apenas uma gota de óleo.

Figura 78 - Regiões onde foram registrados os espectros das amostras de FC e FV testadas com apenas uma gota de óleo por 6 minutos.

Figura 79 - Superfícies das amostras FC (à esquerda) e FV (à direita) antes dos tribotestes.

Figura 80 - Superfícies das trilhas de desgaste das amostras de FC (acima) e da amostra de FV (abaixo) que foram submetidas ao ensaio com duração de 5 minutos

Figura 81 - Superfícies das amostras de FC (à esquerda) e FV (à direita) dentro da trilha de desgaste após o triboteste.

Figura 82 - Imagens do centro da trilha de desgaste da amostra de FC (acima) e FV (abaixo) geradas por interferometria ótica.

Figura 83 - Imagens do centro da trilha de desgaste das amostras de FC (acima) e FV (abaixo) geradas por interferometria ótica.

Figura 84 - Coeficiente de atrito registrado pela SRV para a amostra de ferro fundido cinzento (curva azul) Ci5 e para a amostra de ferro fundido vermicular (curva vermelha) Vi5.

Figura 85 - Coeficiente de atrito registrado pela SRV para a amostra de ferro fundido cinzento (curva azul) Ci6 e para as amostras de ferro fundido vermicular (curva vermelha) Vi6.

Figura 86 - Gráfico de coeficiente de atrito registrado pela SRV com destaque para o período de "acomodação" das superfícies. 
Figura 87 - Curvas de atrito de todos os ensaios executados neste trabalho no intervalo entre 50 e 200 segundos.

Figura 88 - Grafita de ferro fundido cinzento [90]

Figura 89 - Representação do crescimento da grafita vermicular preferencialmente na direção $c$ [78].

Figura 90 - Dispositivo para alinhamento do anel com a amostra de cilindro.

Figura 91 - Amostra de cilindro fixada no porta-amostra.

Figura 92 - Porta-anel e seus elementos.

Figura 93 - Contato conforme, indicando que o alinhamento entre o anel e a amostra é adequado para a execução do ensaio.

Figura 94 - À esquerda um alinhamento incorreto com o anel excessivamente fechado e à direita um exemplo de anel excessivamente aberto.

Figura 95 - Amostra submetida ao triboteste com o alinhamento entre anel e amostra de cilindro adequado. 


\section{LISTA DE TABELAS}

Tabela 1 - Faixas usuais composição dos óleos de motores de combustão interna [13]

Tabela 2 - Fatores importantes que devem ser considerados no delineamento de um triboteste [adaptado de 74].

Tabela 3 - Fatores que podem afetar o atrito dependendo das condições de contato [74].....

Tabela 4 - Oito filmes que afetam o atrito [76].

Tabela 5 - Resistência à tração dos ferros fundidos cinzentos segundo a norma ASTM A 48 [85].

Tabela 6 - Propriedades físicas e mecânicas determinadas pela norma ISO 16112 para ferros fundidos vermiculares.

Tabela 7 - Propriedades dos ferros fundidos vermiculares em função da nodularidade [79]

Tabela 8 - Propriedades dos ferros fundidos vermiculares comparadas com as dos cinzentos [87]

Tabela 9 - Nomenclatura das amostras e análises a que foram submetidas.

Tabela 10 - Propriedades mecânicas obtidas por ensaio de tração dos dois tipos de amostras testados.

Tabela 11 - Características da matriz e das grafitas das amostras de FC.

Tabela 12 - Características da matriz e das grafitas das amostras de FV.

Tabela 13 - Parâmetros de ensaio do triboteste.

Tabela 14 - Microdureza dos microconstituintes das matrizes do FV e do FC.

Tabela 15 - Microdureza da superfície e da trilha de desgaste das amostras de

FC e FV usadas nos ensaios com a amostra submersa em óleo.

Tabela 16 - Quantidades (percentual atômico) de carbono e oxigênio nas superfícies das amostras antes dos tribotestes.

Tabela 17 - Quantidades dos elementos formadores de tribofilme e a sua distribuição em, uma região da trilha de desgaste, obtidas através de mapas de EDS.

Tabela 18 - Quantidades de O, P, S e C nas superfícies das amostras depois dos tribotestes e fora da trilha de desgaste. 
Tabela 19 - Valores dos parâmetros de Greenwood e Williamson calculados para as amostras de FC e FV antes dos tribotestes.

Tabela 20 - Valores dos parâmetros de Greenwood e Williamson calculados para as amostras de FC e FV depois dos tribotestes e dentro da trilha de desgaste.

Tabela 21 - Desgaste das amostras para as amostras de ferro fundido cinzento Cs1, Cs2 e Cs3 e para as amostras de ferro fundido vermicular Vs1, Vs2 e Vs3.....85 Tabela 22 - Tempo de ativação das amostras FC e FV.

Tabela 23 - Microdureza da superfície e da trilha de desgaste das amostras válidas de FV e FC.

Tabela 24 - Quantidades de carbono e oxigênio nas superfícies das amostras antes dos tribotestes.

Tabela 25 - Quantidades dos elementos formadores de tribofilme e a sua distribuição em, uma região da trilha de desgaste, obtidas através de mapas de EDS

Tabela 26 - Microdureza da superfície e da trilha de desgaste das amostras válidas de FV e FC.

Tabela 27 - Quantidades de carbono e oxigênio nas superfícies das amostras antes dos tribotestes.

Tabela 28 - Quantidades dos elementos formadores de tribofilme e a sua distribuição em uma região da trilha de desgaste, obtidas através de mapas de EDS para as amostras de FC e FV após o triboteste de 5 minutos de duração. ....119 Tabela 29 - Quantidades dos elementos formadores de tribofilme e a sua distribuição em uma região da trilha de desgaste, obtidas através de mapas de EDS para as amostras de FC e FV após o triboteste de 6 minutos de duração. ....121 Tabela 30 - Mapas de EDS para o C das amostras testadas submersas em óleo. 133 


\section{LISTA DE ABREVIATURA E SÍMBOLOS}

AISI

ASTM

$\operatorname{CgX}$

CH3

CiX

$\mathrm{COOH}$

CsX

DIN

DLC

EDS

FC

$\mathrm{Fe} 203$

$\mathrm{Fe} 304$

FeMoO4

$\mathrm{FeS}$

FV

HV

ISO

MEV

MoDTC

$\mathrm{MoO2}$

$\mathrm{MoO3}$

MoS2

$\mathrm{Sa}$

SRV

$\operatorname{VgX}$

ViX

VsX

ZDDP

American Iron and Steel Institute

American Society for Testing Materials

Amostras de ferro fundido cinzento testadas em tribômetro com apenas uma gota de óleo.

Alquila

Amostras de ferro fundido cinzento testadas em tribômetro com apenas uma gota de óleo em ensaios interrompidos.

\section{Carboxila}

Amostras de ferro fundido cinzento testadas em tribômetro submersas em óleo.

Deutsches Institut für Normung (Instituto alemão de normatização)

Diamond like carbon

Espectroscopia por energia dispersiva

Ferro fundido cinzento

Hematita

Magnetita

Molibdato de ferro(II)

Sulfeto de ferro

Ferro fundido vermicular

Dureza Vickers

International Organization for Standardization

Microscópio eletrônico de varredura

Dialquiditiocarbamato de Molibdênio

Dióxido de molibdênio

Trióxido de molibdênio

Bissulfeto de molibdênio

Rugosidade média

Schwingung Reibung Verschelei $\beta$ (atrito e desgaste oscilatório)

Amostras de ferro fundido vermicular testadas em tribômetro com apenas uma gota de óleo.

Amostras de ferro fundido vermicular testadas em tribômetro com apenas uma gota de óleo em ensaios interrompidos.

Amostras de ferro fundido vermicular testadas em tribômetro submersas em óleo.

dialquilditiofosfato de zinco

Sulfeto de Zinco 
xviii

ZS

Altura média das asperezas

$\beta S$

Raio médio das asperezas

$\eta$

Densidade de asperezas

$\mu$

Coeficiente de atrito 


\section{SUMÁRIO}

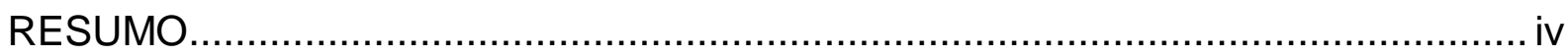

LISTA DE FIGURAS …............................................................................. vii

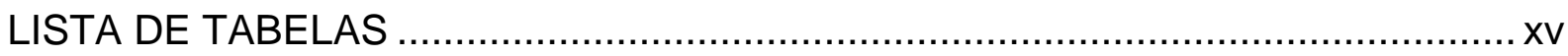

LISTA DE ABREVIATURA E SÍMBOLOS ............................................................ii

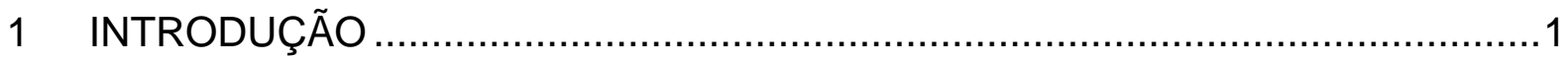

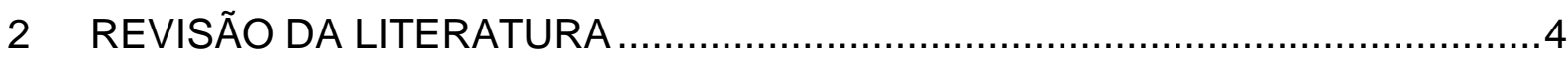

2.1 Tribologia de motores de combustão interna ......................................

2.2 Sistema anel/cilindro

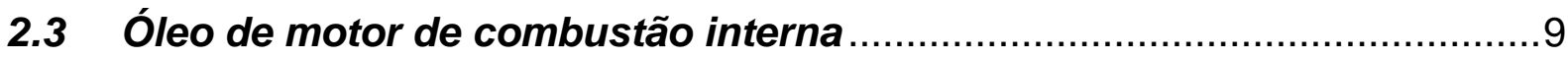

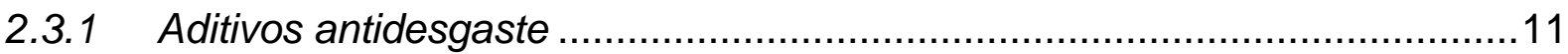

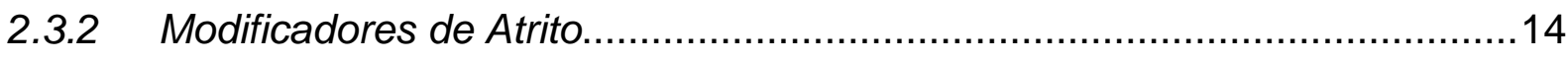

2.3.2.1 Modificadores de atrito orgânicos ..........................................................14

2.3.2.2 Dialquilditiocarbamato de molibdênio (MoDTC) ......................................18

2.4 Influência do tribopar no desempenho tribológico ..................................22

2.4.1 Influência da composição química da superfície ........................................22

2.4.2 Influência da microestrutura do material ...............................................25

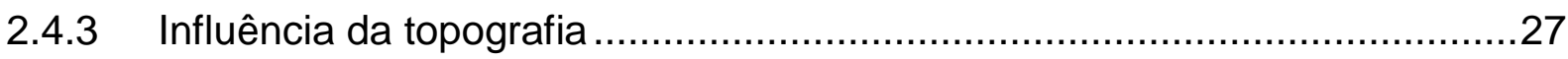

2.5 Tribotestes na simulação do sistema anel/cilindro ..................................29

2.6 Ferros fundidos usados na fabricação de blocos de motor .......................37

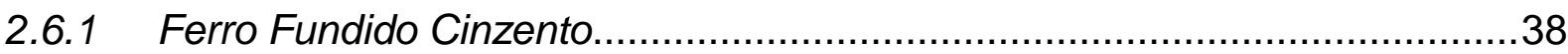

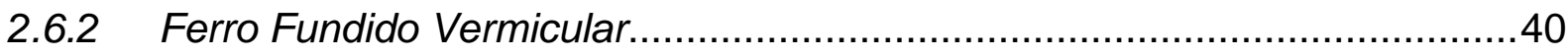

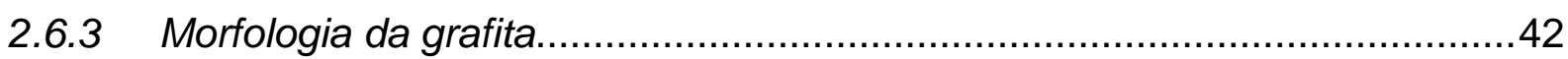

2.7 Aspectos tribológicos dos ferros fundidos ……...................................4

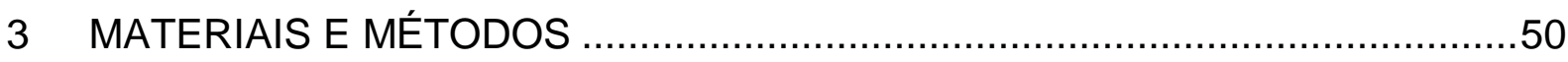

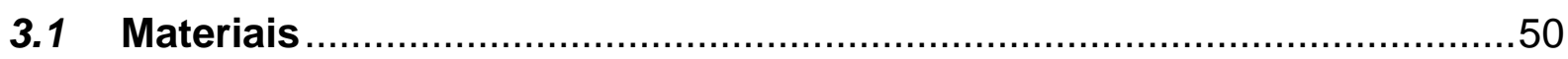

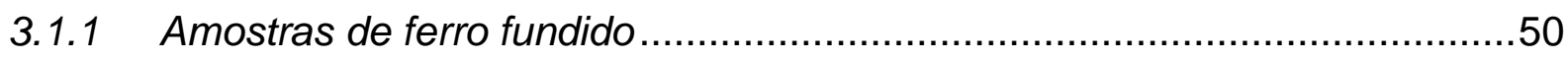




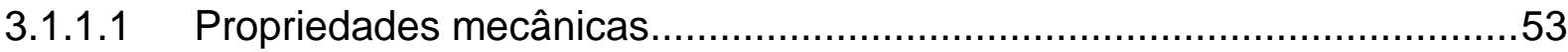

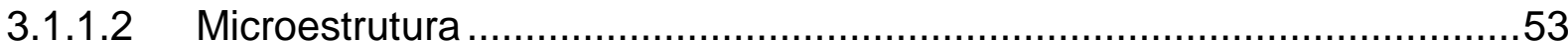

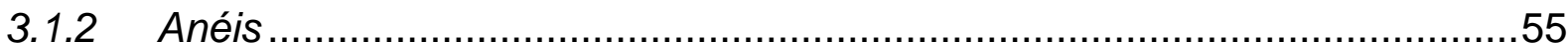

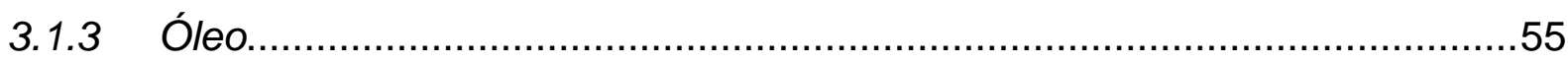

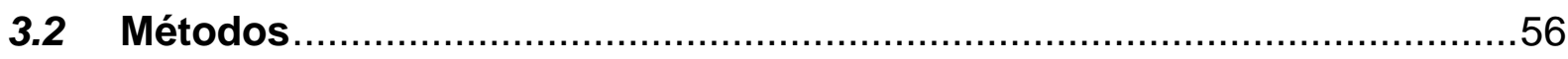

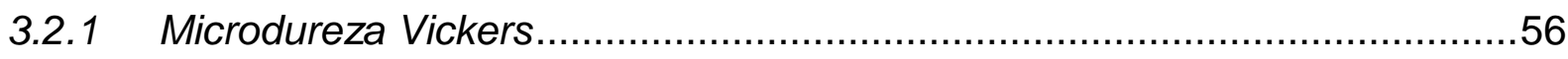

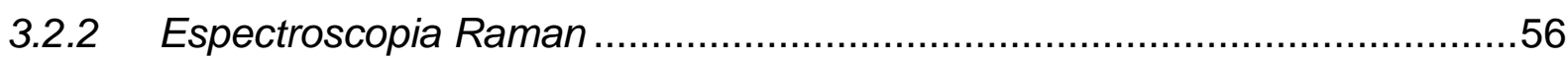

3.2.3 Microscopia eletrônica de varredura ......................................................57

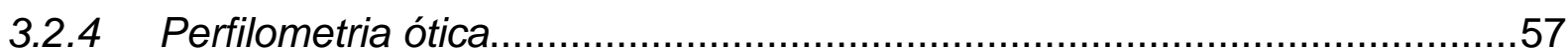

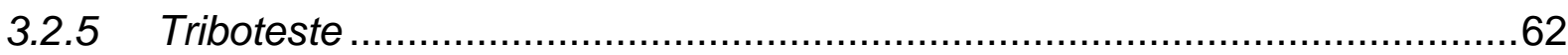

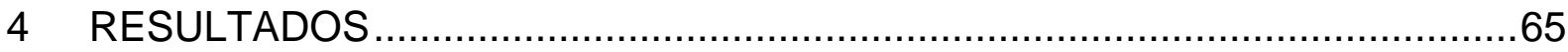

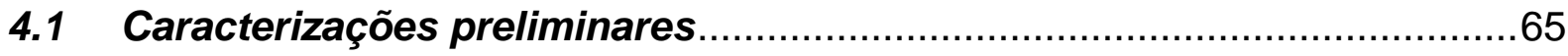

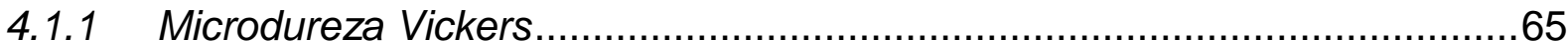

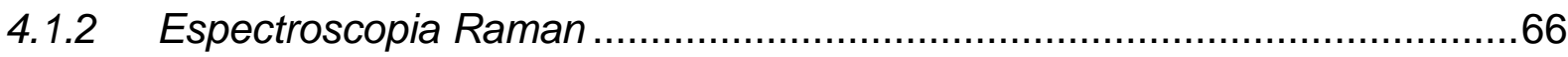

4.2 Ensaios com a amostra submersa em óleo …........................................67

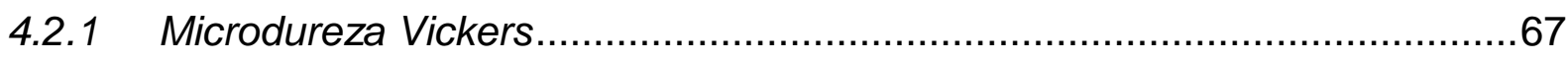

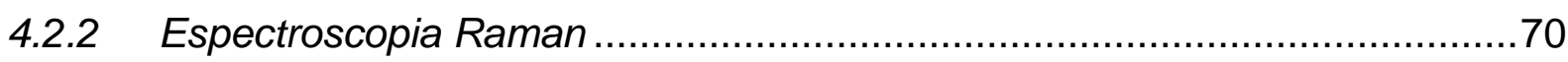

4.2.3 Microscopia eletrônica de varredura ...........................................................74

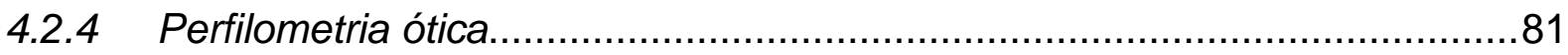

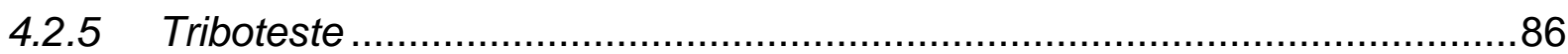

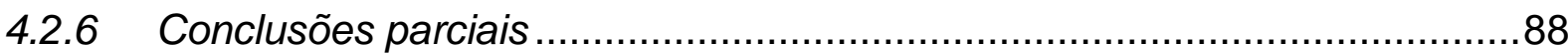

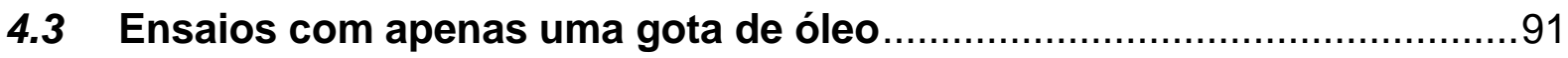

4.3.1 Microdureza Vickers.......................................................................

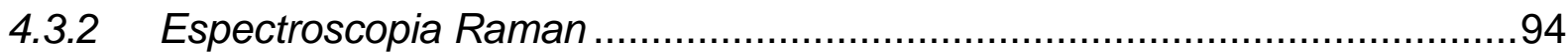

4.3.3 Microscopia eletrônica de varredura ........................................................97

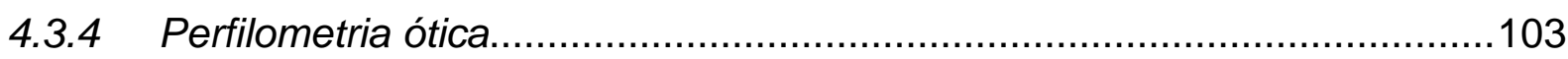

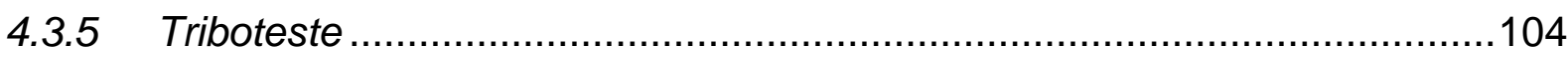




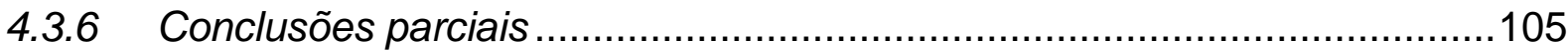

4.4 Ensaios com apenas uma gota de óleo e interrompidos .......................107

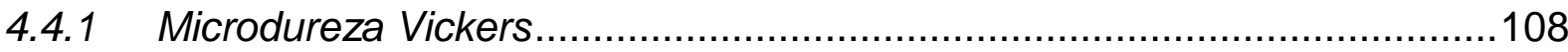

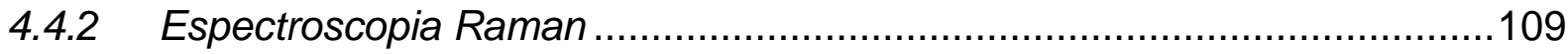

4.4.3 Microscopia eletrônica de varredura .....................................................114

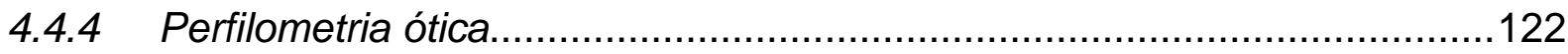

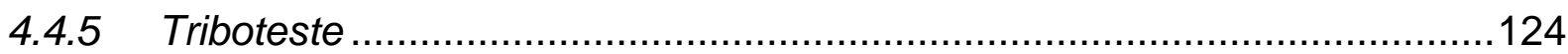

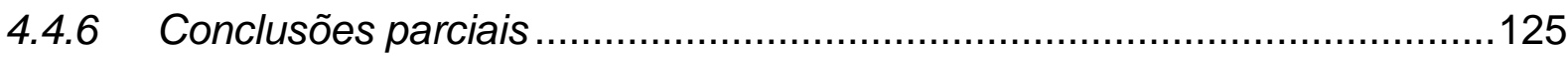

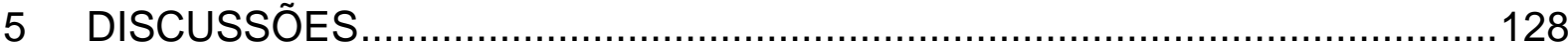

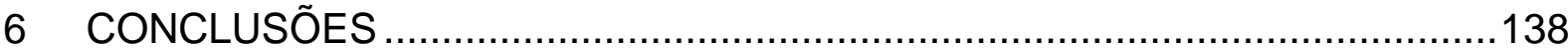

7 SUGESTÕES PARA TRABALHOS FUTUROS ………..............................140

8 APÊNDICE - Alinhamento do anel e da camisa para execução do triboteste.141

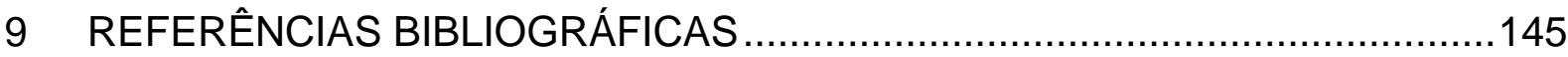




\section{INTRODUÇÃO}

As necessidades de atender legislações cada vez mais rígidas e de satisfazer a um mercado consumidor que tem atentado mais às questões ambientais têm levado montadoras a buscarem alternativas capazes de aumentar a eficiência energética dos veículos. Do total de perdas por atrito em um motor de combustão interna entre 40 e $50 \%$ pode ser atribuído ao sistema anel/cilindro. Como a redução do atrito aumenta a eficiência dos motores e economiza combustível, uma atenção considerável tem sido direcionada ao desenvolvimento de metodologias para avaliação deste tribossistema [3], para melhorar a compreensão dos fenômenos triboquímicos que regem o seu desempenho.

Além disto, há uma classe de ferro fundido que vem ganhando espaço na fabricação de blocos de motores, principalmente em motores diesel. Trata-se do ferro fundido vermicular que apresenta propriedades mecânicas, como tensão de escoamento e módulo de elasticidade, superiores às do ferro fundido cinzento. As propriedades mecânicas superiores do ferro fundido vermicular atendem a uma demanda crescente pelo aumento de potência específica dos motores e redução de peso.

Além das propriedades mecânicas o ferro fundido vermicular tem outras importantes diferenças em relação o ferro fundido cinzento, tipo de ferro fundido mais largamente usado na fabricação de blocos atualmente. As principais diferenças são a composição química, o tamanho, a forma e a distribuição das grafitas e a microestrutura.

Grande parte do esforço demandado para aumentar a eficiência dos motores de combustão interna tem sido aplicado na compreensão e desenvolvimento de soluções tribológicas. Tribologia é o campo da ciência e da tecnologia que estuda superfícies em contato e em movimento relativo e seus fenômenos relacionados. Os principais fenômenos envolvidos com movimento relativo de superfícies em contato são 0 atrito e o desgaste. $O$ atrito e o desgaste são propriedades sistêmicas. Portanto, qualquer alteração na configuração do tribossistema (nome dado a um sistema que está sob uma análise tribológica) acarretará em alteração, de maior ou menor grau, no comportamento do atrito e do desgaste. Além disto, o atrito e o desgaste também podem alterar 0 tribossistema. Por isto, na análise de um 
tribossistema a sua história pregressa é tão importante quanto suas características momentâneas, ou seja, tudo que aconteceu antes alterou o tribossistema e influenciará no seu comportamento futuro.

A tribologia ainda é responsável pelo estudo dos assuntos relacionados à lubrificação. Na prática, a lubrificação acontece através da inserção de qualquer material entre duas superfícies deslizantes que promova a redução do atrito e/ou do desgaste. Estes materiais podem ser óleos lubrificantes, lubrificantes sólidos, filmes depositados nas superfícies, graxas e até tribofilmes que se formam durante o deslizamento das superfícies.

O tribossistema analisado neste trabalho é o sistema anel/cilindro de um motor de combustão interna. Este sistema é lubrificado por um óleo lubrificante automotivo que contem vários aditivos que serão mais bem detalhados na secão 2.3. Uma parte destes aditivos tem a função de reduzir o atrito e o desgaste através da formação de tribofilmes. Os tribofilmes são formados por reações químicas que envolvem os aditivos e a superfície. As reações químicas são induzidas pela energia cinética do deslizamento convertida em energia térmica e mecânica no contato entre as asperezas das superfícies. Como este mecanismo de lubrificação envolve reações químicas ele é estudado por um campo da tribologia chamado de triboquímica.

O conhecimento desenvolvido acerca da formação de tribofilmes a partir dos aditivos dos óleos automotivos e a influência destes aditivos no atrito e no desgaste foi baseado, principalmente, em tribotestes que não utilizam os ferros fundidos no tribopar testado. Por isto, há pouco conhecimento em relação ao papel dos ferros fundidos na formação e no desempenho dos tribofilmes gerados a partir dos aditivos dos óleos automotivos.

Além do óleo e dos seus aditivos o sistema anel/cilindro também pode ter a influência da grafita, que está presente na microestrutura da maioria dos ferros fundidos, na sua lubrificação. A grafita é um composto lamelar à base de carbono que tem baixa tensão de cisalhamento entre as suas lamelas. A grafita, em sua estrutura cristalina, em nada se difere do grafite que é muito usado como lubrificante sólido.

O ferro fundido cinzento e o ferro fundido vermicular possuem grafitas com morfologias diferentes em sua microestrutura. Existe diferença também na estrutura cristalina entre a grafita lamelar do ferro fundido cinzento e a compacta do ferro 
fundido vermicular. Estas diferenças são detalhadas na seção 2.6.3 deste trabalho e tem potencial para afetar o comportamento da grafita como lubrificante sólido e, consequentemente, o desempenho tribológico do sistema anel/cilindro.

O cenário atual confronta a necessidade de aumento de eficiência dos motores de combustão interna com a compreensão incipiente do papel dos ferros fundidos no desempenho tribológico do sistema anel/cilindro. Por isto, este trabalho se propõe a dar sua contribuição científica concentrando os esforços em responder, principalmente, as questões que seguem: Existe diferença entre o tribofilme formado quando o cilindro é fabricado em ferro fundido vermicular em relação ao fabricado em ferro fundido cinzento? Como a quantidade de aditivos disponível no tribossistema influencia o desempenho do ferro fundido cinzento e do ferro fundido vermicular? Qual é o papel da grafita no desempenho do tribossistema? A grafita lamelar tem o mesmo desempenho da grafita vermicular?

\section{Objetivos}

\section{Objetivo geral:}

Comparar o desempenho tribológico dos ferros fundidos vermiculares e cinzentos em condições que simulam as solicitações do ponto morto superior de um motor de combustão interna.

\section{Objetivos específicos:}

- Determinar se existe diferença entre o tribofilme formado nas amostras de ferro fundido cinzento e vermicular.

- Avaliar a influência da quantidade de óleo e, consequentemente, da oferta de aditivos no desempenho do tribossistema.

- Descrever os mecanismos de atuação da grafita e oferecer uma hipótese a respeito da diferença no comportamento tribológico entre as grafitas do ferro fundido cinzento e vermicular. 


\section{REVISÃO DA LITERATURA}

\subsection{Tribologia de motores de combustão interna}

Os motores de combustão interna possuem alguns tribossistemas, cada um com características específicas quanto ao tipo de contato, regime de lubrificação e materiais do par tribológico. Como as propriedades tribológicas são propriedades sistêmicas, os regimes de atrito e a magnitude dos coeficientes de atritos experimentados por diferentes partes de um motor de combustão interna podem variar bastante [1]. Rosenberg [2] menciona que o coeficiente de atrito $(\mu)$ pode variar de 0,2 em situações de lubrificação limítrofe (como trem de válvulas), até 0,001 em situações onde o regime hidrodinâmico é atingido (como no meio do curso dos anéis de pistão e nos olhais maiores das bielas).

Holmberg et al. [3] fez uma estimativa da dissipação de energia em cada sistema de um veículo rodando a uma velocidade de $60 \mathrm{~km} / \mathrm{h}$. Sua conclusão é que cerca de $33 \%$ de toda energia obtida através da queima do combustível e usada para vencer os atrito em diferentes componentes do motor. Deste total (33\%), 17\% é dissipado no motor e nas transmissões. A figura 1 ilustra os as estimativas feitas por Holmberg et al. [3].

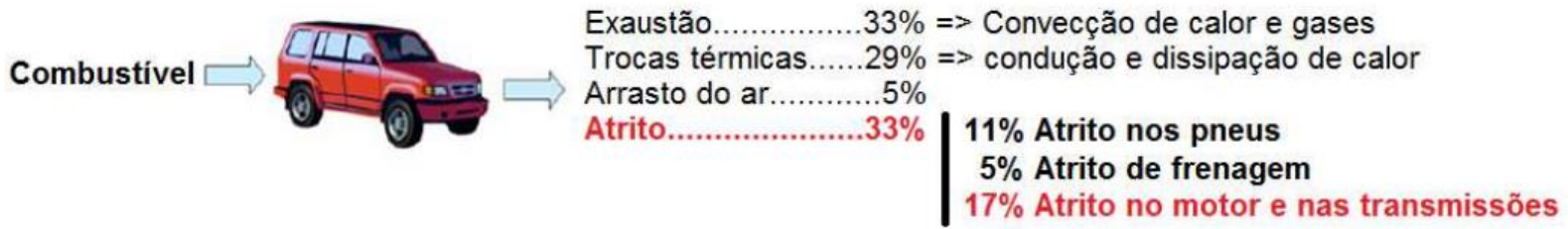

Figura 1 - Estimativa de como a energia obtida do combustível é dissipada em cada sistema para manter um carro rodando a uma velocidade de $60 \mathrm{~km} / \mathrm{h}$ [3].

Interpretando o trabalho de Holmberg et al. [3], Franco [4] concluiu que apenas 11\% da energia total fornecida pelo combustível são usadas efetivamente para mover o motor e que destes, $45 \%$ (5\% do total) são gastos no contato entre cilindro e anéis de pistão. 
O sistema anel/cilindro recebe especial atenção entre os tribossistemas do motor porque, segundo Blau [1], é o maior responsável por dissipações de energia na forma de atrito, o que pode ser observado no gráfico da figura 2.

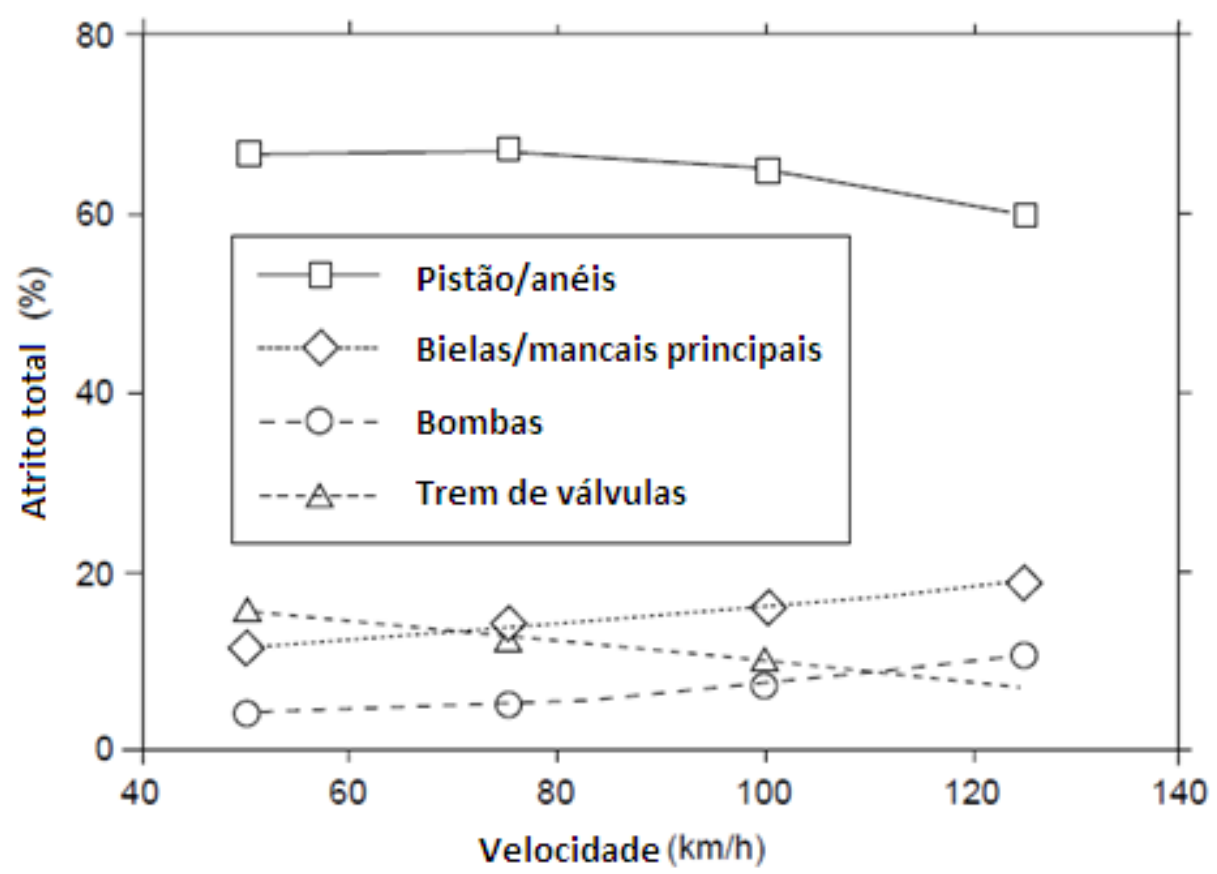

Figura 2 - Efeito da velocidade do veículo na contribuição de cada subsistema no total de atrito dissipado em um motor de combustão interna [1].

\subsection{Sistema anel/cilindro}

O sistema anel/cilindro consiste do conjunto que compreende o cilindro do bloco, dentro do qual ocorre a combustão; os anéis, que na maioria dos motores de combustão interna são três: anel de compressão, anel raspador e anel de óleo; o pistão, que dentre outras funções abriga os anéis, e o óleo lubrificante. Uma imagem esquemática deste sistema está ilustrada figura 3. 


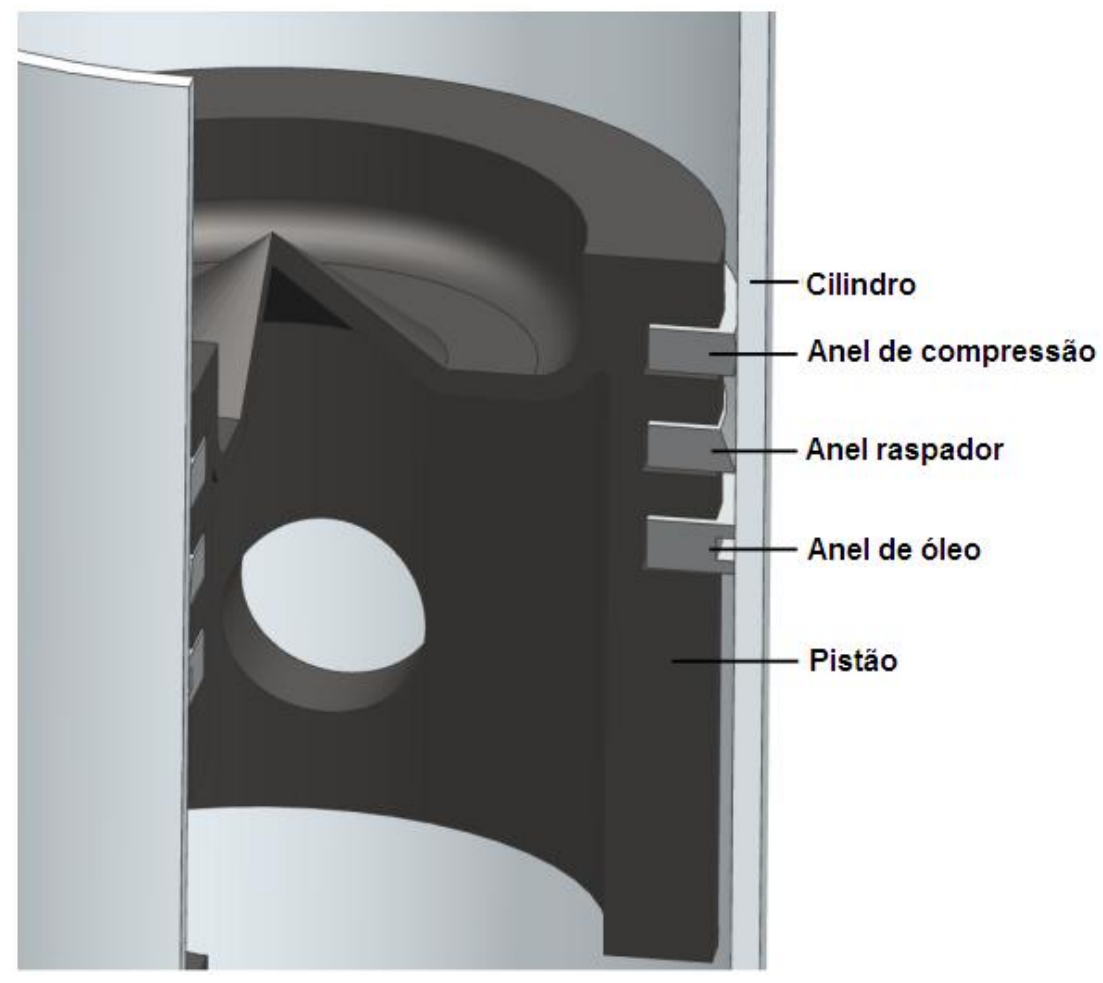

Figura 3 - Sistema anel/cilindro [5].

As funções básicas do pacote de anéis, nome que se dá aos 3 ou mais anéis montados no pistão, são de formar um selo que evite a passagem de gás entre a câmara de combustão e o cárter, limitar o transporte ascendente do óleo a partir do cárter para a câmara de combustão e ajudar na dissipação de calor [6].

A superfície do cilindro é, geralmente, gerada por brunimento que pode ser de vários tipos. Os mais comuns são: "standard honing", "plateau honing", "brush honing", "fluid-jet honing", "laser honing", "slide honing" e "spiral-slide honing" [7]. O bloco usado neste trabalho foi usinado pelo processo de "plateau honing" ou brunimento de platô, que gera áreas de suporte de carga de baixa rugosidade intercaladas por vales profundos, chamados de sulcos de brunimento.

A imagem de uma típica superfície gerada por brunimento de platô é apresentada na figura 4. Os sulcos de brunimento podem agir como reservatórios de lubrificantes e seções de platô que podem funcionar como micro mancais no contato [5,8]. O efeito de mancal pode gerar maior pressão hidrodinâmica [5,9], aumentando assim a espessura do filme de óleo, resultando em menor atrito e desgaste no contato. Cilindros usinados pelo brunimento de platô normalmente levam a um menor consumo de óleo e diminuem o risco da ocorrência de "scuffing" (desgaste severo 
por deslizamento) [7] e desgaste tanto do cilindro quanto do anel [5,10], quando comparados com cilindros usinados por "standard honing".

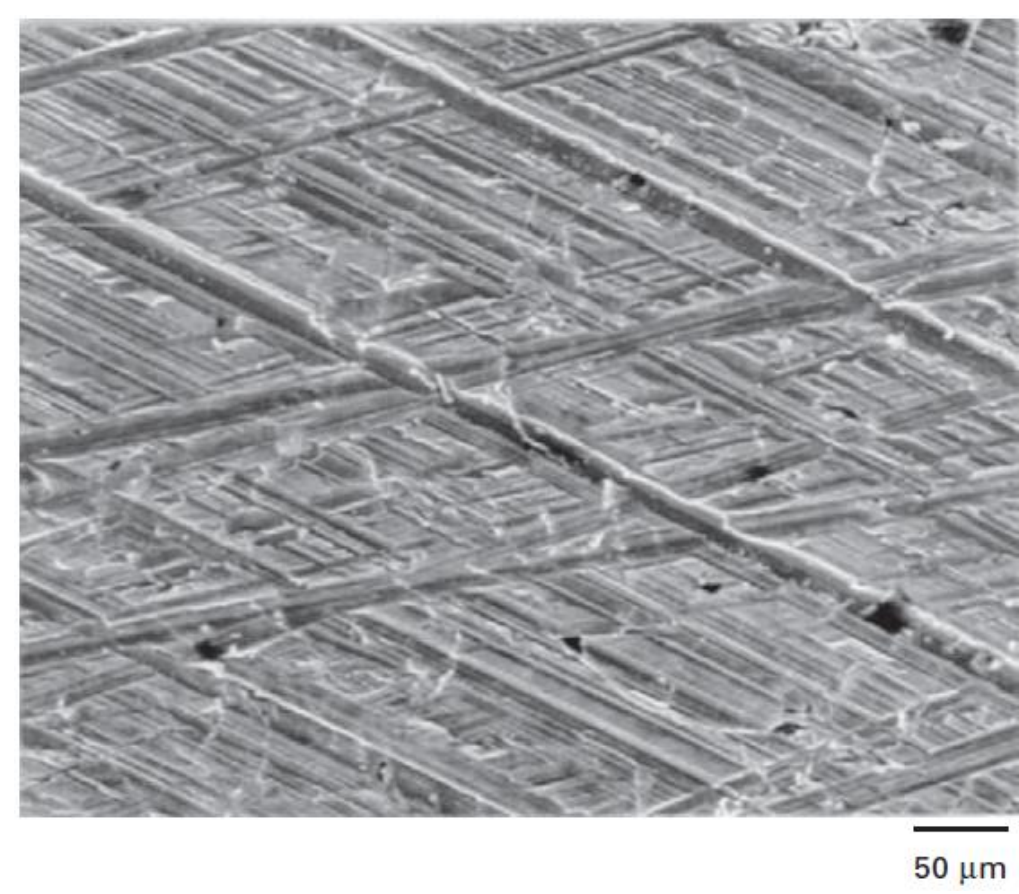

Figura 4 - Superfície típica de um cilindro gerado através do brunimento de platô [86].

As características de operação do tribossistema anel/cilindro, segundo Blau [1], são as que seguem:

"O coeficiente de atrito entre o anel de pistão e o cilindro varia ao longo do curso porque a velocidade relativa vai de zero nos pontos mortos, inferior e superior, até de 10 a $15 \mathrm{~m} / \mathrm{s}$ no meio de curso, dependendo da rotação do motor e do comprimento do curso. Dentro desta variação de velocidade vários regimes de lubrificação podem ser experimentados durante o curso do pistão desde o limítrofe, passando pelo misto até o hidrodinâmico. A espessura de filme de óleo entre o anel e o cilindro pode variar mais de 10 vezes dentro do curso e, em consequência disto, o coeficiente de atrito pode variar de 0,001 até valores superiores a 0,1" [1].

Taylor [11] representou a variação das condições de lubrificação do sistema anel/cilindro e de outros sistemas tribológicos do motor através da curva de Stribeck mostrada na figura 5 . 


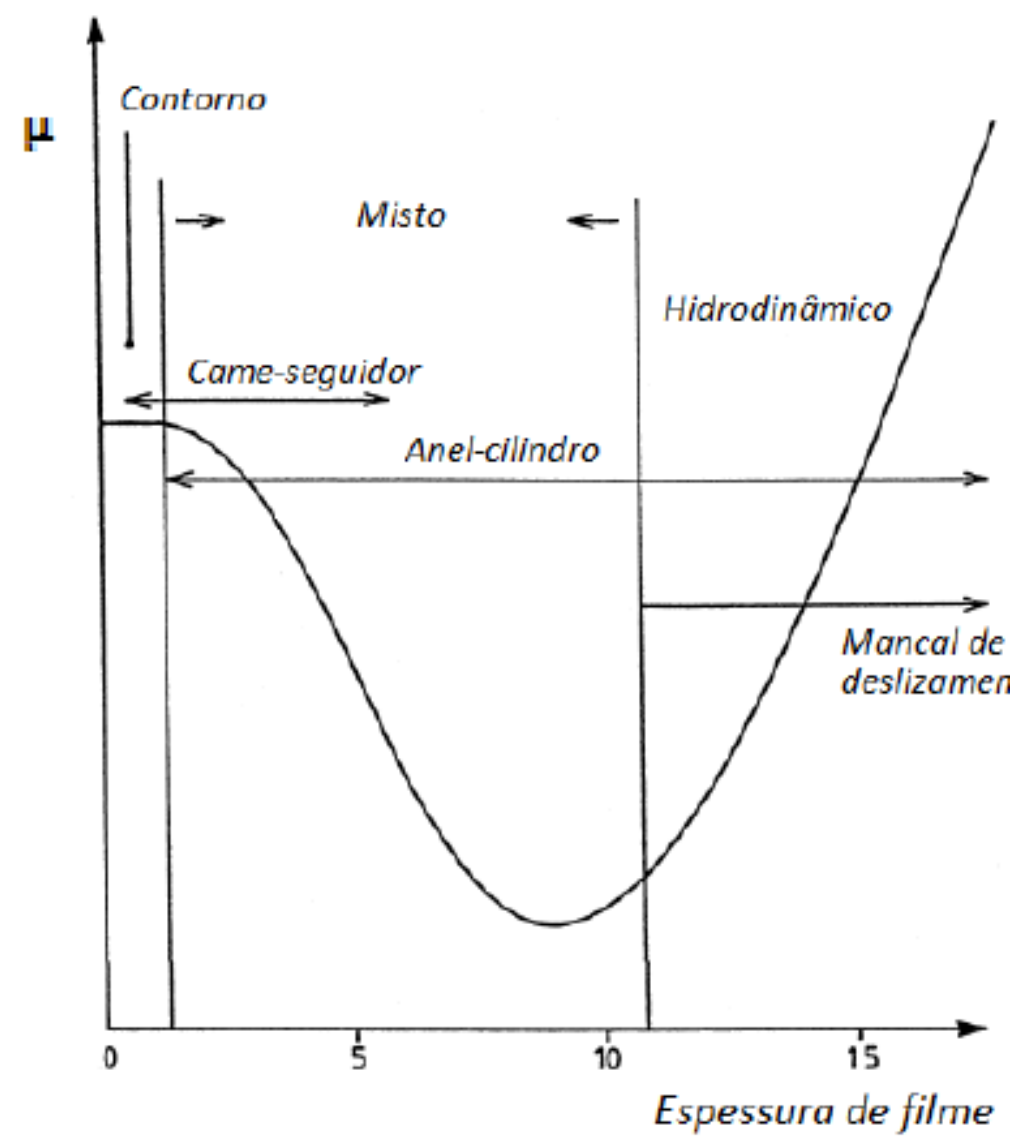

Figura 5 - Curva de Stribeck mostrando os regimes de lubrificação experimentados pelo sistema anel/cilindro e outros sistemas tribológicos do motor [12]

Segundo Sudarshan e Bahduri [111], os principais mecanismos de desgaste em cilindros de motores são adesão, scuffing, abrasão e corrosão, sendo que, na opinião dos autores o desgaste é governado principalmente pelo mecanismo de adesão. Obara [7], estudando os mecanismos de desgaste atuantes no cilindro de um motor flex-fuel concluiu que os mecanismos predominantes são os de abrasão e o desgaste associado a reações triboquímicas e que a adesão e a fadiga de contato têm importância secundária. Santos Filho [12] comparou o desgaste resultante do uso de gasolina e etanol em motores flex-fuel e relatou que em ambos os casos os mecanismos de desgaste encontrados na região do ponto morto superior do cilindro foram: adesão, abrasão, fadiga de contato e corrosão. Neste trabalho o desgaste abrasivo foi atribuído aos resíduos de carbonização.

Como este trabalho está focado em estudar o desempenho tribológico dos ferros fundidos usados na fabricação de blocos de motores em condições que simulam o ponto morto superior de motores de combustão interna o maior interesse está concentrado no regime de lubrificação limítrofe, pois é neste regime que as 
características do tribofilme $\mathrm{e}$, potencialmente, dos materiais, governam $\mathrm{o}$ desempenho do tribossistema anel/cilindro. A condição de lubrificação limítrofe é esperada nos pontos de reversão (ponto morto superior e inferior), como mostra o trabalho de Priest [6].

\section{3 Óleo de motor de combustão interna}

Óleos lubrificantes utilizados em sistemas automotivos são compostos por uma mistura de óleos básicos e aditivos. O tipo e a concentração exata dos componentes são característicos de cada formulação específica e estão relacionados com o nível de desempenho desejado [13].

Segundo Taylor [14] os aditivos dos óleos automotivos tem 3 funções principais como foco em: atrito e desgaste, contaminação e limpeza e manutenção das propriedades do fluido. A tabela 1 traz mais detalhes $e$ as faixas usuais de composição dos óleos para motores de combustão interna.

Tabela 1 - Faixas usuais composição dos óleos de motores de combustão interna [13].

\begin{tabular}{|c|c|c|}
\hline Função & Componente & Concentraçào $(\% \mathrm{~m})$ \\
\hline \multirow{4}{*}{ Atrito e desgaste } & Melhorador de indice de viscosidade & $0 \cdot 6$ \\
\hline & Aditivo antidesgaste & $0,5-2$ \\
\hline & Redutores de atrito & $0 \cdot 2$ \\
\hline & Inibidores de corrosão/oxidaçäo & $0 \cdot 1$ \\
\hline \multirow{3}{*}{$\begin{array}{c}\text { Contaminação e } \\
\operatorname{limpeza}\end{array}$} & Antioxidante & $0 \cdot 1$ \\
\hline & Detergente & $0 \cdot 10$ \\
\hline & D ispersante & $2 \cdot 9$ \\
\hline \multirow{2}{*}{$\begin{array}{c}\text { Manutenção das } \\
\text { propriedades do fluido }\end{array}$} & Abaixadorde ponto de fluidez & $0 \cdot 0,5$ \\
\hline & Aditivo antiespum a & $0 \cdot 0,001$ \\
\hline
\end{tabular}

Trindade [13] divide os aditivos em dois grupos:

- Aditivos cuja atuação se dá principalmente enquanto dispersos ou dissolvidos no seio do óleo (bulk): são aditivos geralmente associados a fenômenos como escoamento hidrodinâmico, reações de oxidação, cristalização ou empacotamento de cadeias parafínicas e formação de micelas [13]. 
- Aditivos cuja atuação se dá principalmente nas interfaces com as superfícies sólidas: em geral, têm como função a redução do atrito e do desgaste e a proteção contra fenômenos indesejados, como corrosão metálica [13].

A figura 6 detalha quais tipos de aditivos se encaixam em cada uma das classificações sugeridas por Trindade [13].

- Detergentes

- Dispersantes

- Inibidores de oxidação

- Melhoradores de índice de viscosidade

- Abaixadores de ponto de fluidez

- Antiespumantes
- Inibidores de corrosão

- Modificadores de atrito

- Aditivos antidesgaste

- Aditivos de extrema pressão

\section{- Óleos básicos}

Figura 6 - Classificação dos aditivos segundo a sua atuação [13].

Levando em consideração as classificações de Taylor [14] e Trindade [13] os tipos de aditivos que serão estudados neste trabalho serão os antidesgaste e os redutores de atrito. Os melhoradores de índice de viscosidade que aparecem na classificação de Taylor [14] como tendo sua função ligada ao atrito e ao desgaste estão contidos na classificação de Trindade [13] como tendo atuação no seio do óleo, ou seja, não atuam diretamente na formação do tribofilmes. Esta aparente divergência ocorre porque os melhoradores de índice de viscosidade atuam predominantemente quando o sistema está operando em regime hidrodinâmico, por isso tem atuação ligada ao atrito e ao desgaste com pouca contribuição na formação de tribofilmes. Os inibidores de corrosão protegem as superfícies metálicas contra o ataque de oxigênio, água, ácidos, bases e sais. São tipicamente aditivos com atividade superficial, que se adsorvem na superfície metálica através de um grupo funcional polar, ao mesmo tempo em que possuem uma cadeia apolar com afinidade pelo óleo básico [13]. Este tipo de aditivo atua formando uma barreira entre a superfície sólida e o ambiente [15]. Apesar de formar um filme protetor sobre a superfície não 
foram encontradas na literatura indicações da sua influência nas propriedades tribológicas do sistema anel/cilindro.

\subsubsection{Aditivos antidesgaste}

Existem vários tipos de aditivos antidesgaste usados em formulações de óleos. Nos óleos de motor o que é mais comumente usado é o dialquilditiofosfato de zinco [16] (ZDDP ou ZnDDP). O ZDDP é usado para controlar o desgaste e inibir a oxidação em quase todos os óleos de motor assim como em vários outros tipos de lubrificantes [17].

"As propriedades do ZDDP são largamente governadas pelo tamanho e estrutura do seu radical. O aril ZDDP é o mais estável termicamente, mas geralmente não é usado em óleos para. Moléculas com o grupo alquil primário ramificado são as mais estáveis depois das que possuem o grupo aril, seguida pelos ZDDPs com grupos primários, secundários e terciários de alquil. O comprimento da cadeia do radical alquil afeta a solubilidade e a estabilidade térmica da molécula de ZDDP. Por isto, uma distribuição de álcoois com alto e baixo peso molecular é usada objetivando o bom desempenho do óleo em uma grande faixa de variação de operação. O ZDDP em óleos para motores são geralmente compostos de $85 \%$ de alquil secundário mais $15 \%$ de alquil primário" [14].

A molécula de ZDDP e seus radicais estão representados na figura 7.

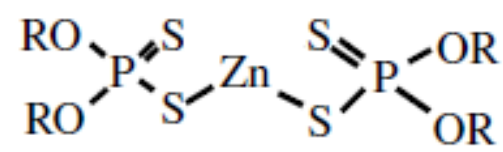<smiles>CCO</smiles><smiles>CC(C)O</smiles><smiles>CC(C)(C)O</smiles>

Radical terciário

Figura 7 - Molécula de ZDDP e seus radicais. 
Dawczyk et al. [18] avaliou a taxa de formação do tribofilme de ZDDP de um óleo com moléculas com radicais secundários e outro com uma mistura de radicais alquilas. $O$ resultado mostrou que não houve diferença até os tribofilmes atingirem entre 100 e $200 \mathrm{~nm}$ de espessura. Além disto, ele também testou radicais de arila que apresentaram taxa de formação do tribofilme menor e atingiu a espessura máxima de $50 \mathrm{~nm}$. A espessura do filme de ZDDP pode influenciar, principalmente, na sua durabilidade. Outra influência dos radicais da molécula de ZDDP no comportamento do tribofilme gerado foi detectada por Ueda et. al. [19]. O seu trabalho mostrou que os tribofilmes gerados de ZDDPs com radicais primários se convertem de estruturas amorfas para nanocristalinas mais lentamente que os tribofilmes de ZDDP secundário. As estruturas nanocristalinas propiciam maior capacidade de carga e resistência ao desgaste [19].

Existem três principais mecanismos propostos para justificarem a ação antidesgaste do ZDDP [20]:

- Formação de um filme que protege as superfícies do contato mecânico direto.

- Remoção dos radicais peróxidos corrosivos.

- "Digestão" partículas duras e, portando, abrasivas de óxido de ferro [21, 22]. O mecanismo de atuação antidesgaste do ZDDP mais aceito é o de formação de tribofilme que atua como barreira para o contato direto entre as superfícies em deslizamento [84,85]. A figura 8 traz uma proposta de um diagrama esquemático de como é a estrutura e a composição de um tribofilme formado a partir do ZDDP.

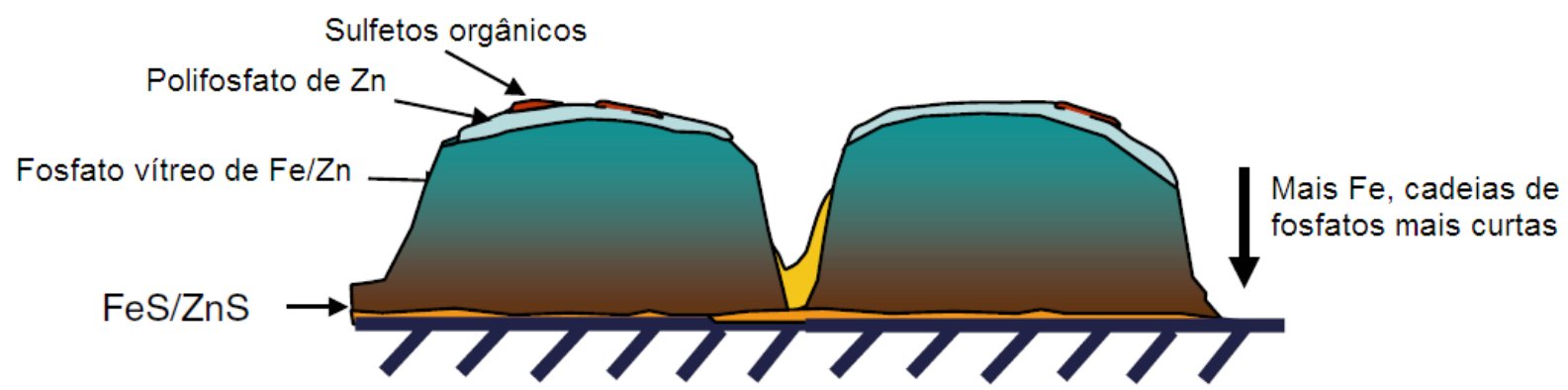

Figura 8 - Diagrama esquemático da estrutura e da composição do tribofilme formado a partir do ZDDP [20].

O mecanismo de formação dos tribofilmes ainda não está completamente consolidado. Segundo Martin et al. [21] uma vez que o aditivo anti-desgaste atinge a 
superfície, ele deve construir uma camada estrutural efetiva. No caso do ZDDP, há uma reação de oxidação na superfície, seguida de um processo de condensação por polimerização, resultando em um filme de fosfato vítreo (frequentemente composto por orto-, piro-, poly, e meta-fosfatos). A redução do comprimento da cadeia de polifosfato seria resultado do processo químico entre as cadeias longas de polifosfato, formadas da decomposição do ZDDP, com partículas de desgaste de óxido de ferro [21, 22]. Esta abordagem propõe que o desgaste abrasivo a três corpos não acontece porque o ZDDP digere as partículas de óxido de ferro no seu processo de formação do tribofilme. Bailey e Cameron [23] defendem que a formação do ZDDP não depende da natureza das superfícies. Nestes estudos a formação do tribofilme a partir do ZDDP não apresenta relação com a presença de óxidos de ferro e as cadeias curtas de polifosfato seriam provenientes da hidrólise das cadeias longas.

Zhang et al. [17] mostraram que o que controla a taxa de formação do tribofilme de ZDDP é a tensão de cisalhamento a que a solução com a molécula é submetida. Além disto, com ensaios usando o tribômetro MTM-SLIM e um microscópio eletrônico de transmissão Ueda et al. [19] defendem que o tribofilme de ZDDP é submetido a uma transformação de uma estrutura predominantemente amorfa para uma nanocristalina induzida pelo contato deslizante. Isto ocorre por causa da depolimerização das inicialmente formadas cadeias de polifosfato em fosfatos muito mais curtos, possivelmente predominantemente ortofosfatos, tendo como força motriz a temperarura, a tensão aplicada e a difusão dentro do tribofilme de agentes depolimerizados, incluindo cátions de ferro [19]. Esta transformação da estrutura do tribofilme resulta em um filme mais durável e resistente [19].

O conhecimento estabelecido sobre o tribofilme antidesgaste formado a partir do ZDDP indica que:

- A molécula de ZDDP se adsorve às superfícies através dos seus radicais.

- A reatividade dos radicais afeta a taxa de formação e a espessura do tribofilme.

- A taxa de formação do tribofilme também é função da tensão de cisalhamento a que a molécula é submetida.

- O crescimento do tribofilme tem como força motriz temperarura, a tensão aplicada e a difusão dentro do tribofilme de agentes depolimerizados. 
- O tribofilme ganha resistência através de um processo de transformação da sua estrutura de amorfa para nanocristalizada.

- A composição química do tribofilme contêm os átomos de Zn, P, S, C, H e Fe (quando a superfície de contato é constituída de uma liga a base de ferro).

\subsubsection{Modificadores de Atrito}

Modificadores de atrito são aditivos comumente usados em condições de lubrificação limítrofe e/ou mista para ajustar as características do atrito, aumentar a lubricidade e a eficiência energética [24]. Modificadores de atrito que reduzem o coeficiente de atrito são usados e formulações de óleos para caixas de câmbio e motores [24]. Diversas classes de compostos químicos podem ser empregadas como modificadores de atrito, algumas das quais puramente orgânicas e outras organometálicas [13]. Existem três tipos de modificadores de atrito para lubrificantes de motores de combustão interna: compostos organometálicos à base de molibdênio, modificadores de atrito orgânicos e nanopartículas [24]. Os dois principais e mais comumente usados nas formulações de óleo para motor são os compostos organometálicos à base de molibdênio e os modificadores de atrito orgânicos [24, 25]. Dialquilditiocarbamatos de molibdênio (MoDTC) estão entre os modificadores de atrito mais empregados em lubrificantes automotivos [13]. Dentre os compostos organometálicos à base de molibedênio este trabalho dará enfoque ao MoDTC porque o óleo utilizado nos tribotestes possui este composto, conforme identificado previamente por Acero [26].

\subsubsection{Modificadores de atrito orgânicos}

Desde que foi descoberto em 1915 que a adição de ácidos graxos em óleos minerais poderia reduzir o atrito [27], uma grande quantidade de estudos têm sido realizados sobre o mecanismo de atuação dos modificadores de atrito orgânicos [24].

Modificadores de atrito orgânicos são geralmente moléculas longas com uma cadeia de hidrocarbonetos linear composta de pelo menos 10 átomos de carbono e um 
grupo polar em uma das extremidades [28]. Quimicamente, modificadores de atrito orgânicos podem ser divididos nas categorias que seguem [29].

a) Ácidos carboxílicos e seus derivados. Exemplo: ácido esteárico.

b) Amidas, imidas, aminas e seus derivados. Exemplo: oleilamida

c) Derivados de ácidos fosfórico e fosfônico.

d) Polímeros orgânicos. Exemplo: metacrilatos

Um exemplo de cada categoria é apresentado na figura 9.

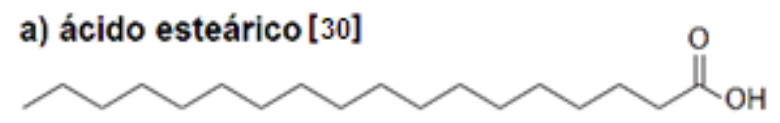

b) oleilamida [31]

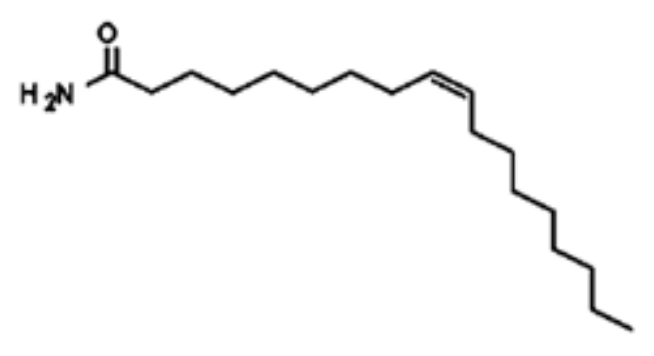

c) diéster de ácido alquilfosfônico [24]<smiles>[R]OP([R])(=O)O[R]</smiles>

d) alquil metacrilato [31]<smiles>[R]OC(=O)C(=C)C</smiles>

Figura 9 - Exemplos de modificadores de atrito orgânicos.

Atualmente há dois mecanismos para explicar como os modificadores de atrito orgânicos atuam para reduzir o atrito que são amplamente aceitos: modelo de monocamada e modelo de filme espesso [24]. No primeiro uma camada monomolecular separa as superfícies e o efeito de lubrificação acontece pela geração de uma interface de baixa tensão de cisalhamento [16]. Segundo este mecanismo duas monocamadas, uma em cada superfície, seriam suficientes para prevenir o contato direto entre as superfícies em deslizamento e assim reduzir o atrito [24, 32-34]. Suas propriedades de redução do atrito são fortemente dependentes do comprimento da sua cadeia e dos grupos funcionais da extremidade da molécula [24, 35,36]. Este mecanismo está ilustrado na figura 10. 


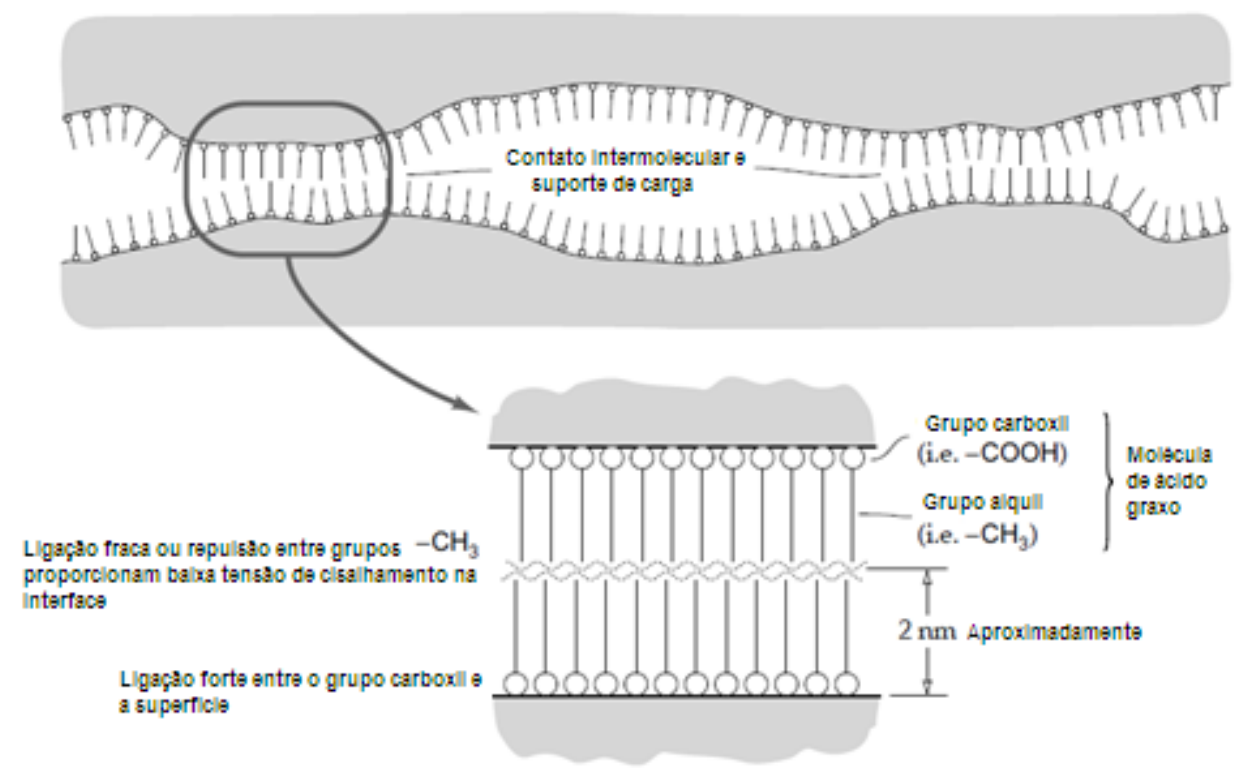

Figura 10 - representação gráfica do mecanismo de lubrificação por monocamada do ácido carboxílico [16].

"O mecanismo clássico, para explicar as propriedades de redução de atrito dos modificadores de atrito orgânicos, é que as moléculas anfifílicas se alto autoorganizam em uma superfície sólida polar para formar densas monocamadas orientadas verticalmente. Elas reduzem o atrito porque propiciam um fácil deslizamento entre os grupos metil que ficam no topo das monocamadas. Os filmes são fortes e aptos a suportar elevadas pressões por causa das forças cumulativas de van der Waals entre os grupos metilenos das cadeias alquilas que se encontram bastante próximas. O grupo polar serve para fixar a molécula na superfície sólida e sua ligação pode ser reversível ou, especialmente com ácidos carboxílicos, envolver reação química e, por isto, se tornar irreversível [31]."

Apesar da aceitação geral do modelo e monocamada, outros autores [24, 37-40] propuseram o modelo de filme espesso, onde os modificadores de atrito orgânicos formam um filme viscoso de dezenas ou centenas de nanômetros de espessura, e isto foi confirmado por uma variedade de técnicas, como difração de raios-x e interferometria de filme ultrafino. As condições para formação dos filmes espessos a partir dos modificadores de atrito orgânicos não serem completamente compreendidas, mas já foi mostrado que ácidos carboxílicos de cadeias longas formaram filmes espessos apenas quando carboxilatos metálicos são gerados pela reação química do ácido com a superfície [41]. 
Existem algumas evidências que quanto o metal é atritado contra outro metal em condições quentes e úmidas, filmes espessos são formados por ácidos carboxílicos [31]. Porém, ainda não está estabelecido se estes filmes mais espessos influenciam na performance ou se eles são removidos em condições moderadas fazendo com que $o$ atrito seja regido por uma remanescente monocamada [31].

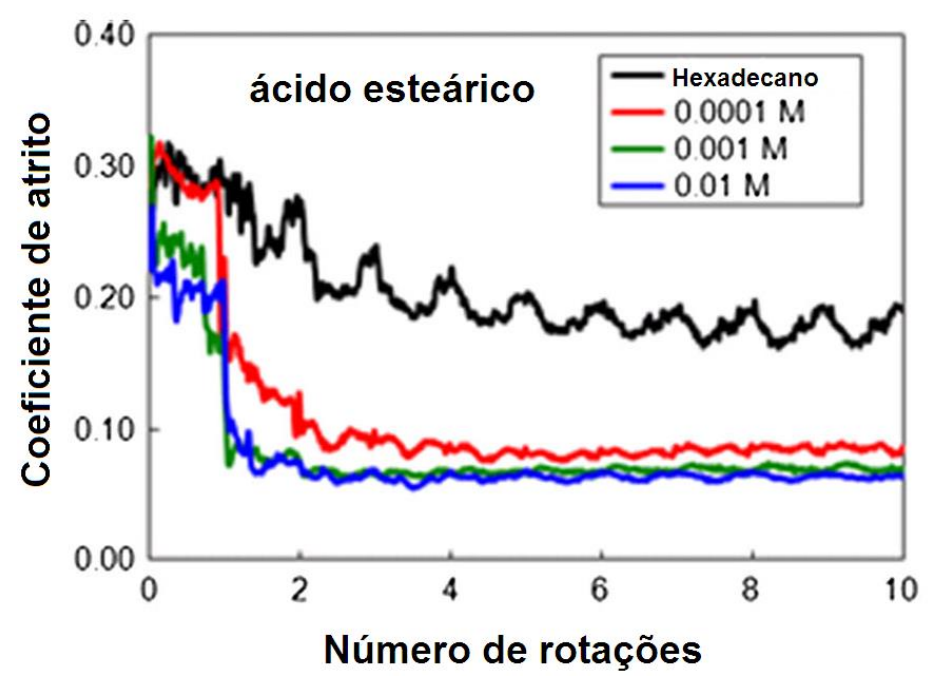

Figura 11 - Comportamento do atrito nas primeiras 10 rotações em um teste de baixa velocidade na configuração esfera sobre disco. Soluções em hexadecano a $35 \stackrel{\circ}{\mathrm{C}}$ [42].

A figura 11 mostra um gráfico que ilustra a capacidade dos modificadores de atrito orgânico de reduzir o atrito, no caso o ácido esteárico. É possível observar neste gráfico que a redução do coeficiente de atrito depende da concentração do ácido esteárico na solução de hexadecano e que, aparentemente, atinge o seu limite de efetividade quando atinge $0,01 \mathrm{M}[31,43,44]$. Vale ressaltar que 0 trabalho de Campen [42] foi feito utilizando um tribossistema bastante simplificado em relação a região do ponto morto superior de um motor de combustão interna. O lubrificante utilizado possuía apenas 2 componentes enquanto o óleo de motor automotivo possui vários (como já foi apresentado na seção 2.3). A temperatura de ensaio utilizada por Campen [42] foi de $35 \stackrel{\circ}{\circ} \mathrm{C}$ enquanto em um motor de combustão a ignição do gás pode ocorrer acima de $500 \cong \mathrm{C}$ em motores a diesel. A velocidade de ensaios adotada foi baixa e constante. Em um motor a velocidade de deslizamento do anel no cilindro pode variar de zero $15 \mathrm{~m} / \mathrm{s}$. Portanto o comportamento de redução de atrito encontrado por Campen [42] que foi atribuído a ação de um modificador de atrito não pode ser usado para inferir que o mesmo ocorre na região 
do ponto morto superior de um motor de combustão interna. Para isto seria necessário executar tribotestes em condições mais próximas da condição real de operação de um motor de combustão interna.

O conhecimento sobre os mecanismos de atuação dos modificadores de atrito orgânicos ainda não estão completamente estabelecidos. Há um consenso sobre o mecanismo de monocamada, mas não há estudos que comprovem a sua atuação no sistema anel/cilindro. O conhecimento sobre o mecanismo de filme espesso é ainda mais incipiente. Está claro que em algumas condições de tribossistema eles ocorrem, mas o seu mecanismo de formação ainda não foi completamente descrito nem o mecanismo pelo qual promove a redução do atrito. Este mecanismo também não foi observado em tribossistemas que simulem as condições de operação do sistema anel/cilindro de um motor de combustão interna. Na seção 2.4.1 é apresentado um mecanismo sugerido por Stachowiak [16] que chama o filme formado de camada de "soap".

\subsubsection{Dialquilditiocarbamato de molibdênio (MoDTC)}

Os compostos contendo molibdênio foram estudados como potenciais aditivos de lubrificantes nos anos 50 [45], inicialmente eram usados como antidesgaste [46,47]. Eles foram considerados como modificadores de atrito pela primeira vez no final dos anos 70 [48,49]. Diferentes tipos de aditivos a base de molibdênio têm sido aplicados em formulações de óleos [46]. O que tem mostrado o melhor desempenho em lubrificantes modernos para motores é o dialquilditiocarbamato de molibdênio (MoDTC), vastamente utilizado para melhorar a eficiência energética atuando como modificador de atrito. A figura 12 traz a representação de uma molécula de MoDTC.

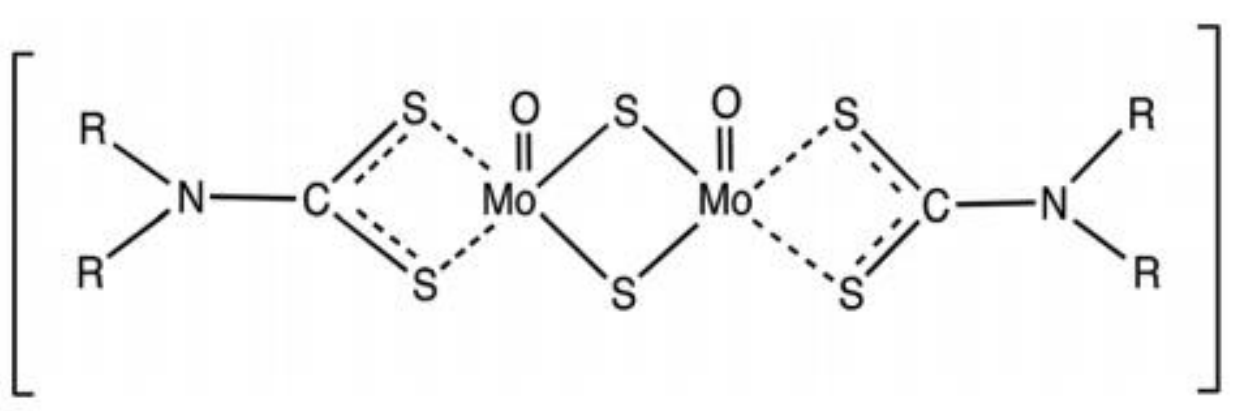

Figura 12 - Molécula de dialquilditiocarbamato de molibdênio [50]. 
No MoDTC os átomos nas posições do oxigênio podem ser tanto oxigênio quanto enxofre. O mais comum é que seja oxigênio, mas o aditivo é geralmente mais reativo quando é o enxofre que ocupa a posição do oxigênio [31]. O MoDTC possui a capacidade de reduzir atrito em sistemas como o anel/cilindro porque durante 0 deslizamento, se as suas condições de ativação forem atingidas, se transformará em $M_{2}[13,26,31,50,52,53]$. O bissulfeto de molibdênio é um conhecido lubrificante sólido com estrutura lamelar que possui resistência ao cisalhamento extremamente baixa entre suas lamelas.

As curvas características de atrito em função do tempo do MoDTC um coeficiente de atrito inicial seguido por uma queda repentina para valores tipicamente entre 0,03 e 0,08 [31]. Esta queda repentina do coeficiente de atrito promovida pelo MoDTC se convencionou chamar de ativação [13,26]. A figura 13 mostra este comportamento para dois MoDTCs produzidos com os mesmos radicais, mas com níveis de impureza diferentes.

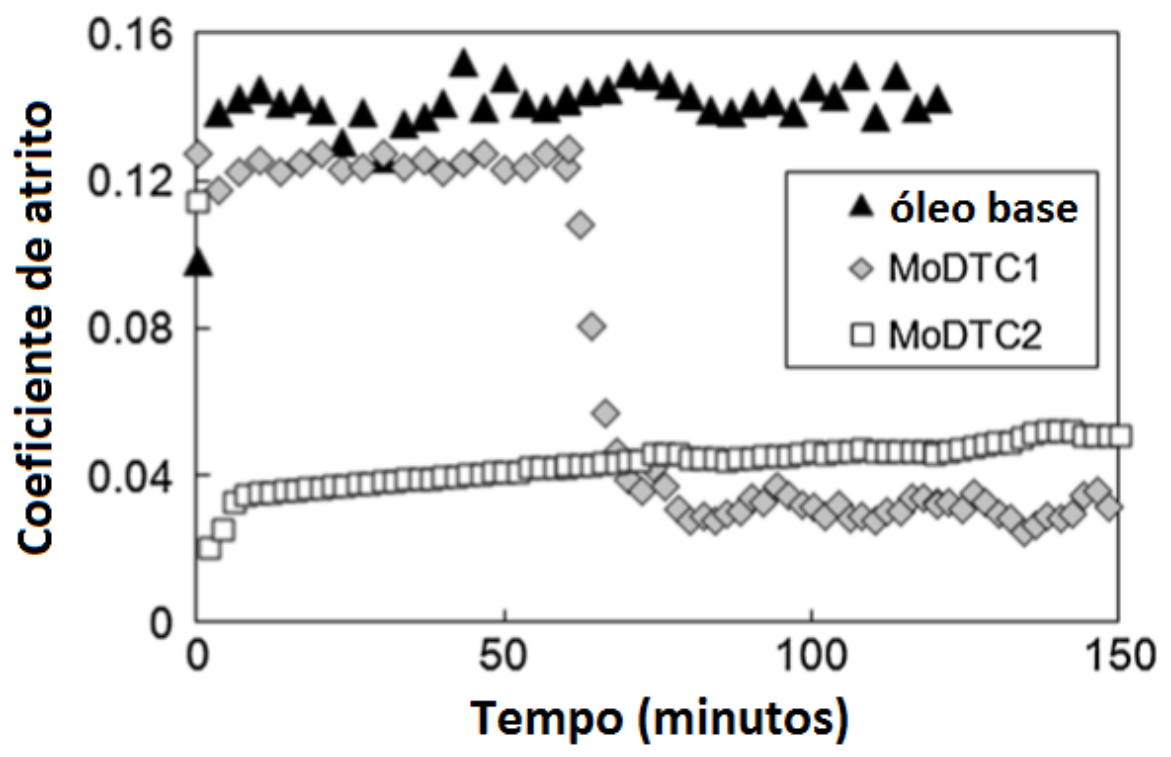

Figura 13 - Redução do atrito por dois MoDTCs diferentes [31, 51]

A ativação do MoDTC também pode ser detectada através da presença de $\mathrm{MoS}_{2}$ na trilha de desgaste $[13,26,53] .0 \mathrm{MoS}_{2}$ pode ser detectado na trilha de desgaste usando espectroscopia Raman. Os picos relativos a presença de $\mathrm{MoS}_{2}$ no espectro Raman ficam localizados por volta de 380 e $412 \mathrm{~cm}^{-1}$ [53]. Estas posições podem 
variar um pouco de acordo com os parâmetros de análise (potência e comprimento de onda do laser) utilizados.

Sobre a cinética de formação do filme de $\mathrm{MoS}_{2}$ não há consenso entre os autores. Grossiord et al. [52] sugerem que a decomposição do MoDTC em $\mathrm{MoS}_{2}$ ocorre em três etapas de acordo com a Figura 14.

a

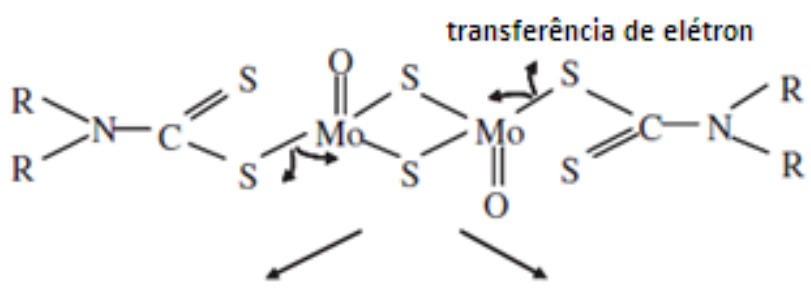

b

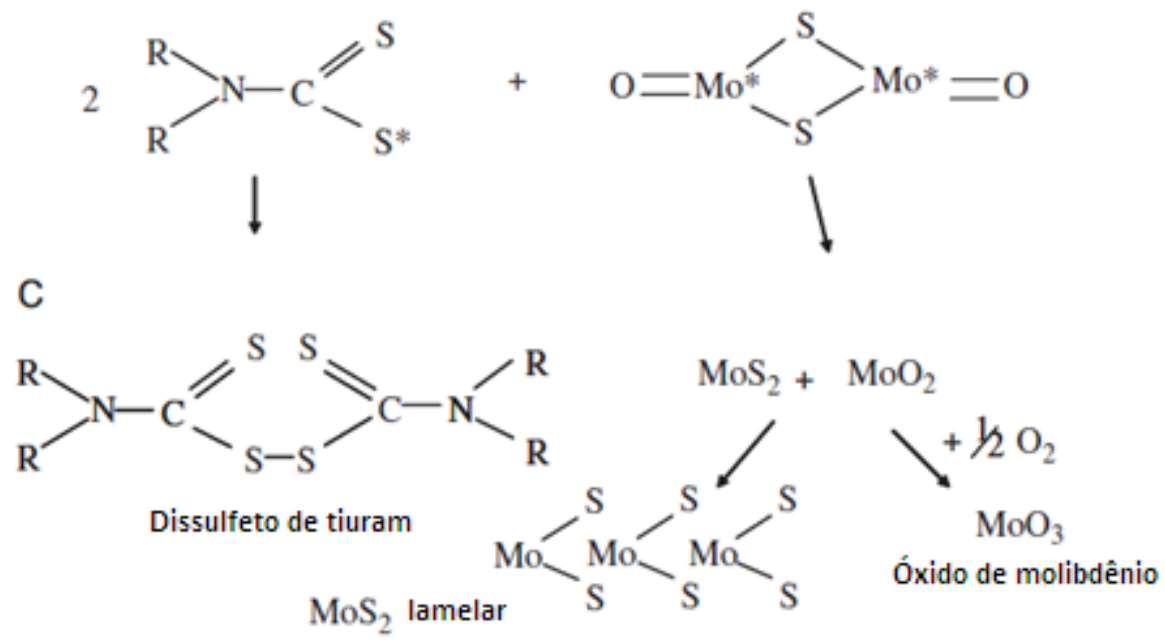

Figura 14 - Etapas para decomposição do MoDTC em $\mathrm{MoS}_{2}$ [52] a) transferência de elétrons das ligações químicas Mo-S. b) formação de radicais livres. c) recombinação dos radicais promovendo a formação do dissulfeto de tiuram, enquanto o outro radical se decompõe em MoS2 e MoO2.

Segundo o mecanismo proposto por Grossiord et al. [52] a primeira fase da ativação do MoDTC corresponde a transferência de elétrons das ligações químicas Mo-S, levando a formação de radicais livres. A segunda fase seria a recombinação dos radicais promovendo a formação do dissulfeto de tiuram, enquanto o outro radical se decompõe em $\mathrm{MoS}_{2}$ e $\mathrm{MoO}_{2}$.

O mecanismo de ativação do MoDTC mais aceito atualmente foi proposto por Khaemba et al. [53]. Este mecanismo está ilustrado na figura 15. 


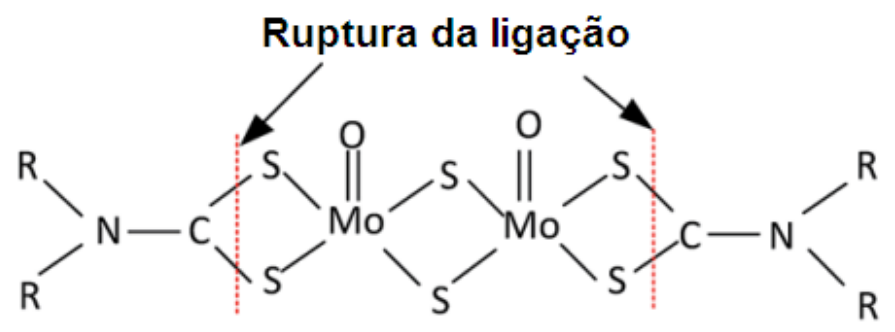

MoDTC

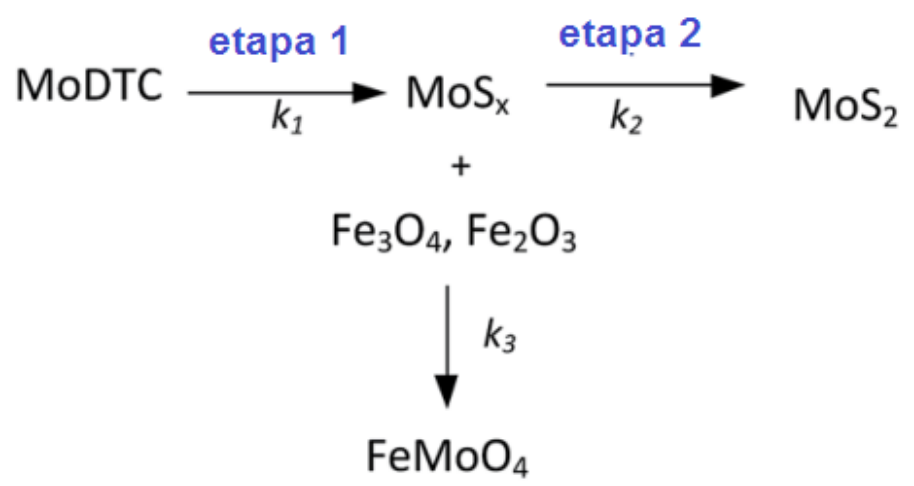

Figura 15 - Mecanismo de formação do $\mathrm{MoS}_{2}$ a partir do MoDTC proposto por Khaemba et al. [70].

O mecanismo de ativação do MoDTC proposto por Khaemba et al. [53] obedece às seguintes etapas:

- A molécula de MoDTC adsorve nas superfícies do tribopar.

- Na etapa 1, a decomposição da molécula de MoDTC é promovida pela tensão de cisalhamento imposta a ela. O processo de decomposição começa pela ruptura da ligações C-S formando um composto intermediário de molibdênio que passa por uma sulfonação intramolecular formando MoS $_{x}$ amorfo.

- Na etapa 2 o $\operatorname{MoS}_{x}$ e convertido em $M_{0} S_{2}$. A energia de formação do MoS $x$ é inferior a da formação do $\mathrm{MoS}_{2}$, por isto, ela ocorre antes. A formação do $\mathrm{MoS}_{2}$ ocorre por depois de um incremento de energia no sistema promovido pelo aumento da tensão de cisalhamento ou da temperatura.

- Por último, a formação do $\mathrm{FeMoO}_{4}$ seria resultado da reação dos óxidos de ferro com o MoS .

Independente do mecanismo proposto para a ativação do MoDTC é consenso que redução de atrito ocorre pela formação de um filme de $\mathrm{MoS}_{2}$ que evita o contato direto entre as superfícies do tribopar e reduz o atrito devido a baixa tensão de cisalhamento entre suas lamelas. Este filme de $\mathrm{MoS}_{2}$, segundo o modelo proposto 
por Khaemba et al. [70], é formado com participação do Fe presente nos materiais do tribopar (disco de AISI 1050 e esfera de 52100) que foram usados em seus testes. Isto indica que o material do tribopar pode ter influência na formação do tribofilme de $\mathrm{MoS}_{2}$ a partir do MoDTC.

\subsection{Influência do tribopar no desempenho tribológico}

As superfícies, do ponto de vista tribológico, podem ser descritas segundo sua composição química, sua microestrutura e sua rugosidade. Todas estas características influenciam no comportamento tribológico de um tribossistema.

\subsubsection{Influência da composição química da superfície}

Como este trabalho trata do estudo ferros fundidos o principal interesse está concentrado nas superfícies metálicas e, por isto, esta seção tratará principalmente desta classe de materiais.

Com os metais, além da presença de irregularidades na superfície, a superfície sólida em si é coberta por filmes [54]. Sobre a superfície deve haver uma camada de adsorbato, que é constituída de vapor de água ou hidrocarbonetos presentes no ambiente que podem condensar e se tornar fisicamente adsorvidas à superfície sólida [54]. A camada adsorvida, em geral, se deposita sobre uma camada de óxidos. Abaixo da camada de óxido da superfície deve haver uma região altamente deformada como resultado do processo de fabricação da superfície [54].

As condições de contato entre as superfícies irão determinar se a camada adsorvida e a camada de óxidos serão ou não removidas e isto influenciará na reatividade da superfície nascente. A figura 16 ilustra o processo de geração de uma superfície nascente. 


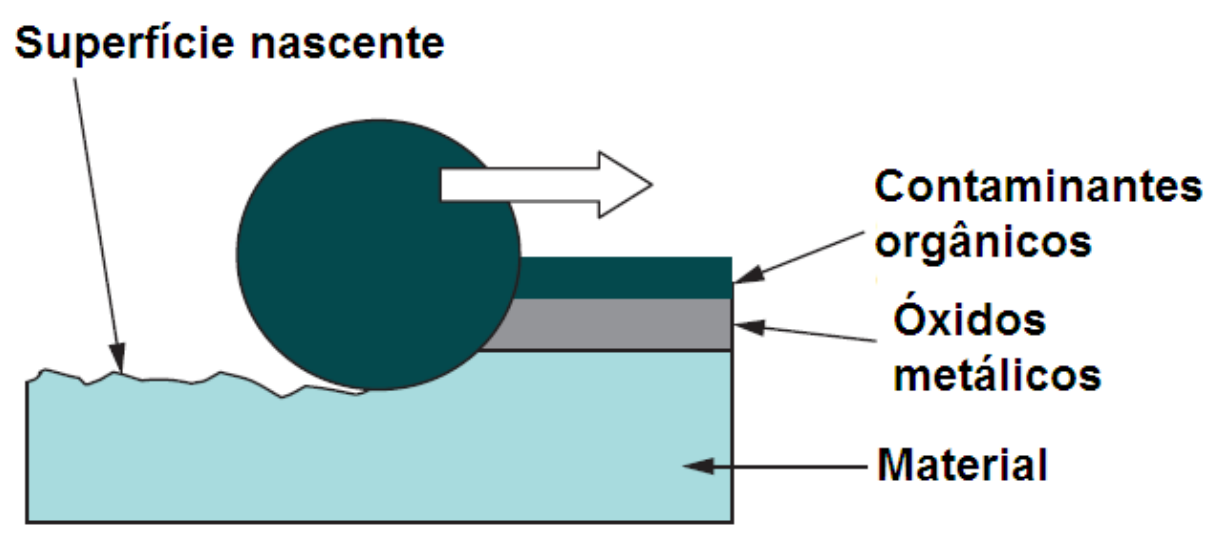

Figura 16 - Processo de geração da superfície nascente durante o deslizamento [55].

Segundo Morecroft [56] as superfícies que possuem a sua camada de óxidos removida pelo processo de desgaste não são adequadas para o processo de lubrificação por adsorção porque se tornam excessivamente reativas para este mecanismo. O mecanismo de lubrificação por adsorção acorre, segundo Stachowiak [16], geralmente, com modificadores de atrito orgânicos em tribossistemas que operam em baixas temperaturas, baixas cargas e baixas velocidades de deslizamento. Este mecanismo pode ocorrer com o próprio filme adsorvido na superfície dos metais, desde que as condições sejam brandas suficientes para não removê-los.

Segundo Stachowiak [16] quando há moléculas de ácidos graxos atuando no tribossistema e as camadas adsorvidas e de óxidos são removidas há uma reação dos ácidos graxos com a superfície metálica formando um filme espesso que ele chama de camada de sabão. Este tipo de tribofilme está ilustrado na figura 17.

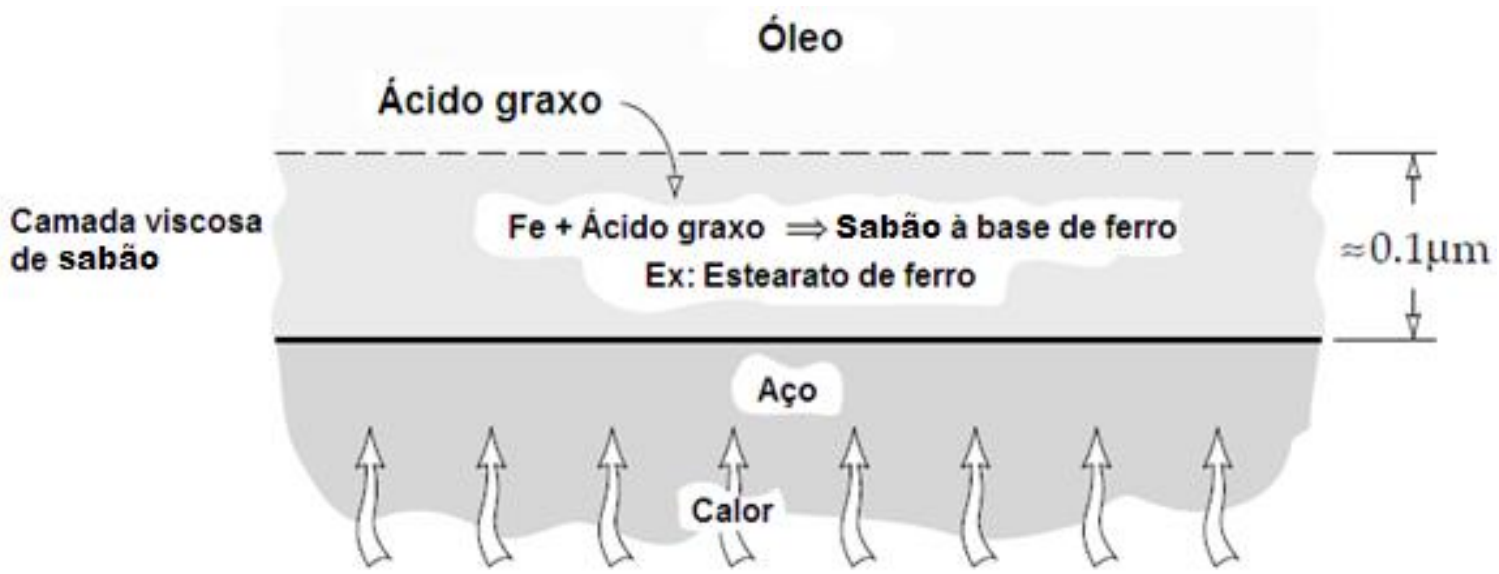

Figura 17 - Formação de filme espesso a partir de ácidos graxos, também chamado por Stachowiak de camada de sabão [16]. 
O metal do qual o material do tribopar é feito também tem influência na reatividade do metal nascente. Portanto, também influencia nas características do tribofilme formado e no desempenho do tribossistema. Mori [55] avaliou a atividade da superfície nascente do alumínio e do níquel em relação há várias moléculas diferentes. O gráfico com os resultados deste estudo se encontra na figura $18 \mathrm{e}$ mostra que a maior parte das moléculas utilizadas no estudo possui maior afinidade com o alumínio enquanto o benzeno apresentou baixa adsorção no alumínio e alta no níquel.

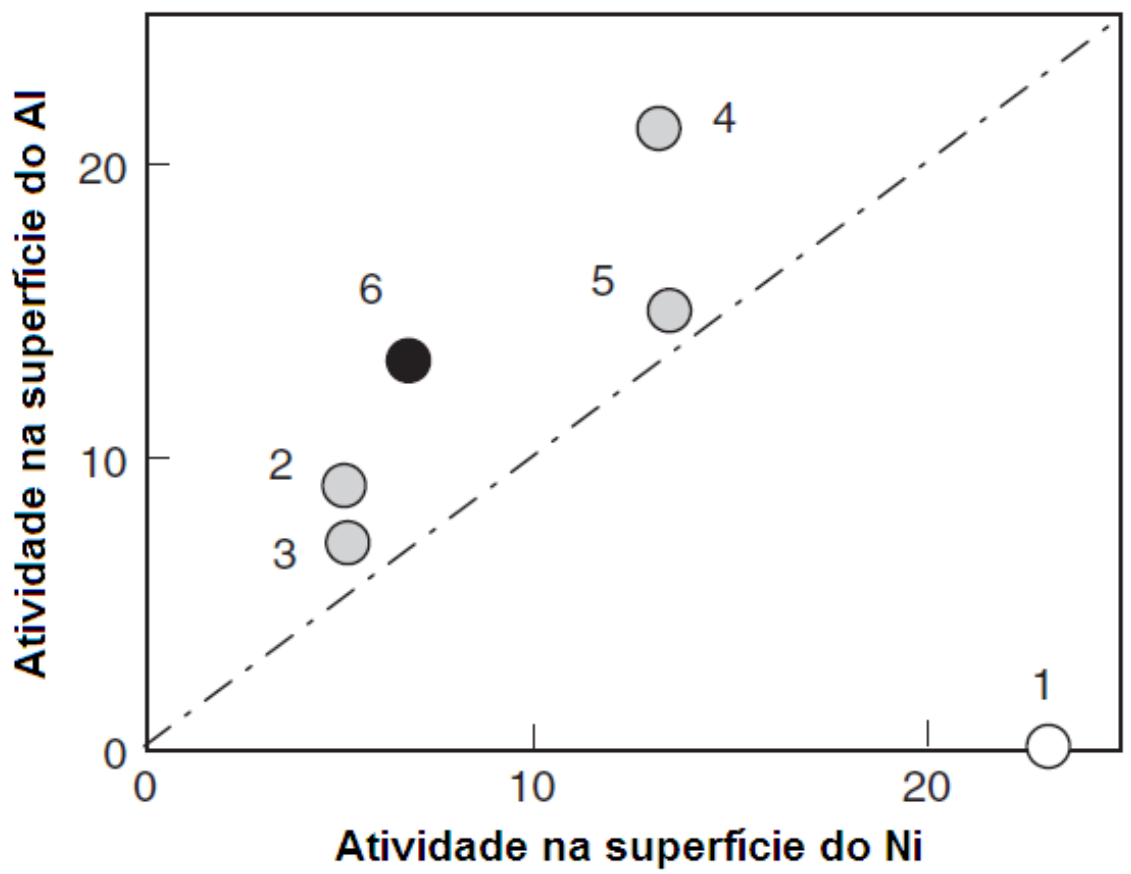

Figura 18 - Comparação da atividade superficial do alumínio e do níquel para componentes orgânicos. 1 - benzeno, 2 - etanol, 3 -n-butil éter, 4 -sec-butil éter, 5 - acetone, 6 - sulfeto de etila [55].

O material das superfícies também pode ter influência na durabilidade do filme monomolecular de ácido esteárico. Minami et al. [57] testou esferas de safira, vidro e aço contra uma placa de silício revestida com uma camada monomolecular de ácido esteárico. Seus resultados mostraram que a maior durabilidade e menor atrito foram alcançados com a esfera de vidro, seguida pela de safira e por último a de aço.

O MoDTC aparentemente é capaz de formar tribofilmes sobre uma grande gama de superfícies, incluindo o DLC (Diamond like carbono) [31], sobre tribofilmes de ZDDP [58] e revestimentos cerâmicos [59]. Isto sugere que a formação das lamelas redutoras de atrito de $\mathrm{MoS}_{2}$ não envolve uma reação específica com metal ou óxido 
metálico, mas deve ser uma reação intramolecular induzida pela tensão aplicada [31].

O filme anti-desgaste, por outro lado, é geralmente menos efetivo em superfícies como a do alumínio e de cerâmicas [60]. Aparentemente a natureza química e mecânica do substrato tem um papel crucial na formação, adesão e composição do filme anti-desgaste [61].

Apesar de a microestrutura e a composição química dos ferros fundidos estarem intimamente conectados é possível fazer alterações na composição química sem afetar drasticamente a microestrutura. Isto ocorre, por exemplo, quando se aumenta percentual de um determinado elemento de liga sem que seja atingido o limite de solubilidade. Desta maneira não há precipitação de uma nova fase e, portanto, há alteração da composição química sem alteração da microestrutura. Também é possível alterar a microestrutura sem alterar a composição química. Um exemplo comum disto são os tratamentos térmicos. Por isto, houve a necessidade de tratar neste trabalho da influência da composição química e da microestrutura no comportamento de um tribossistema separadamente.

\subsubsection{Influência da microestrutura do material}

Os mecanismos de lubrificação limítrofe são fortemente influenciados pela reatividade da superfície, que por sua vez pode ser influenciada pela microestrutura. Há trabalhos [23, 64 - 68] que mostram que aços com diferentes microestruturas possuem diferentes reatividades e, portanto, diferentes desempenhos quando lubrificados por adsorção. Nestes trabalhos a ferrita apresenta 0 melhor desempenho e a austenita o pior.

Sobre a influência da microestrutura do ferro fundido no desempenho tribológico do sistema cilindro/anel/óleo foram encontrados apenas dois trabalhos [62 e 63] com conclusões semelhantes. No trabalho de Keller et al. [62] trabalho foi adicionado fósforo a um ferro fundido cinzento para avaliar a influência da steadita no desempenho tribológico do sistema. O resultado verificado foi que a presença de steadita não afeta o coeficiente de atrito do sistema e não contribui para a geração do tribofilme. Isto pode ser observado na imagem da figura 19. A contribuição da steadita se deu no aumento da resistência ao desgaste. 
(a)

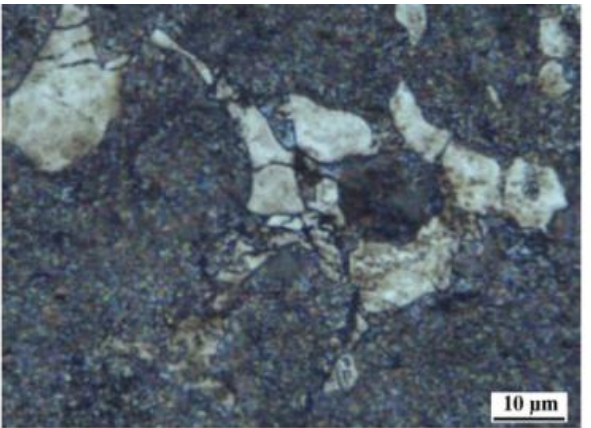

(b)

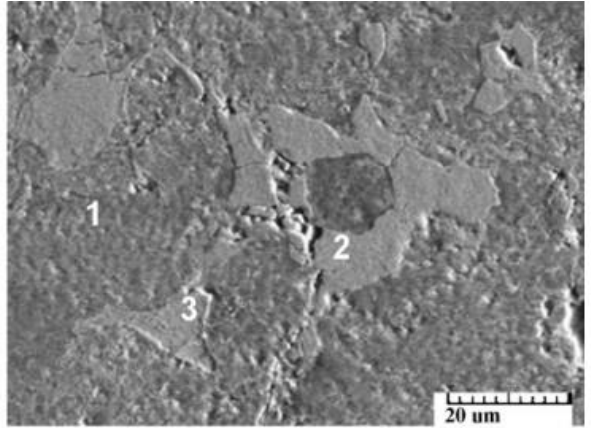

Sem elementos dos aditivos do lubrificante

Sem tribofilme formado

(c)
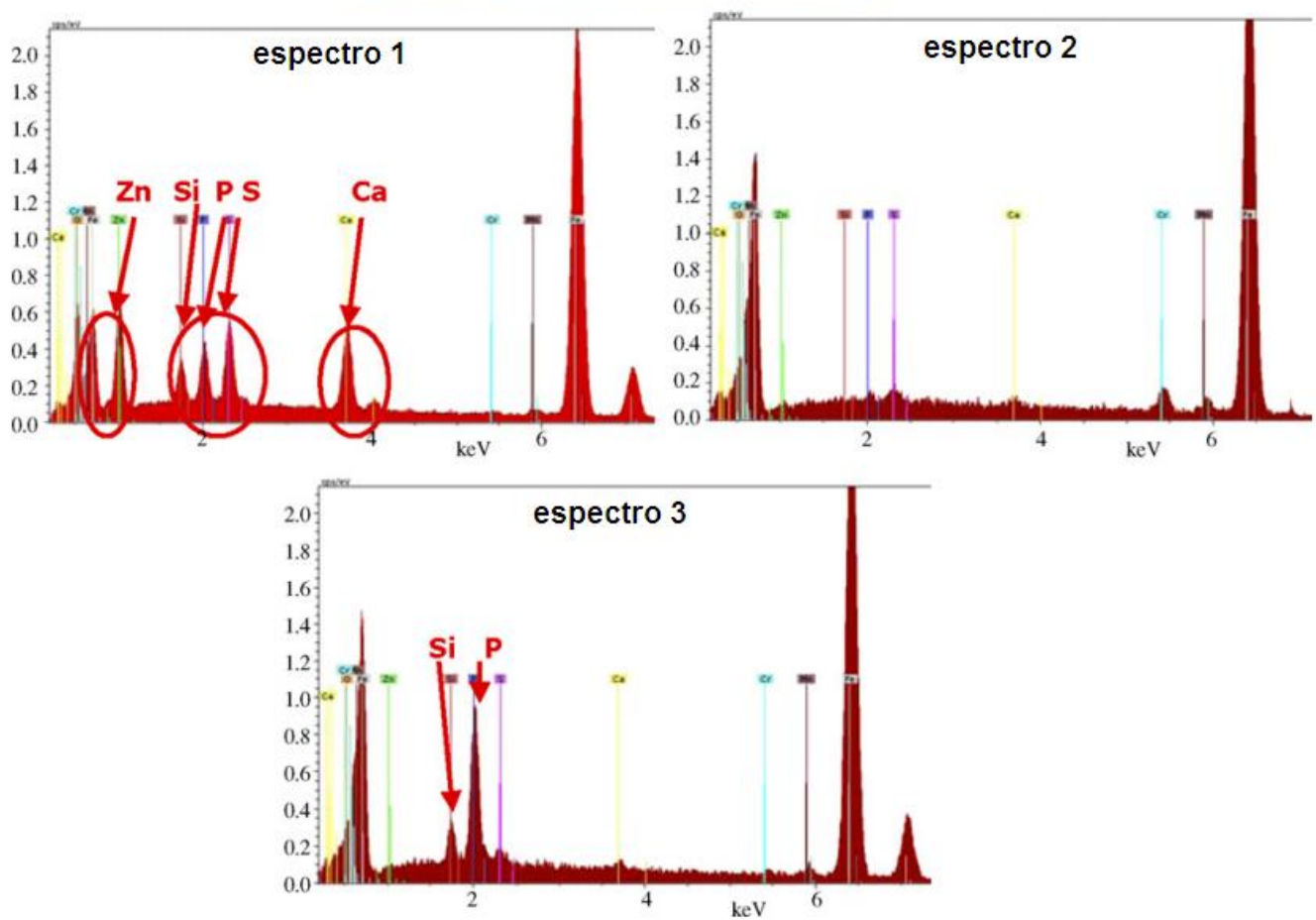

Figura 19 - Composição química da trilha de desgaste de um ferro fundido rico em fósforo, com steadita na sua microestrutura. Na figura (a) uma foto de microscopia ótica de uma região com carbonetos e steadita (regiões mais claras). Figura (b) é uma imagem de MEV indicando os pontos onde foram registrados os espectros de EDS. O espectro 1 foi registrado fora da área da steadita e mostra uma região rica em elementos presentes nos aditivos de óleo ( $\mathrm{Zn}, \mathrm{P}, \mathrm{S}$ e $\mathrm{Ca}$ ). O espectro 2 foi registrado em cima do carboneto e não detectado nenhum elemento do aditivo neste ponto. $O$ espectro 3 foi colhido na região da esteadita e também não detectou a presença de elementos dos aditivos. 
Não foi encontrada nenhuma referência que trate do papel da grafita do ferro fundido na formação de tribofilme antidesgaste nem sobre a formação de tribofilmes redutores de atrito. Além disto, sabe-se pouco sobre a influência da grafita adicionada como lubrificante, ou como aditivo de lubrificante, no desempenho tribológico do sistema anel/cilindro. Porém, Gardos [69] identificou um efeito sinergístico entre o grafite e o $\mathrm{MoS}_{2}$ quando são usados como lubrificantes sólidos. Ele sugere que a grafita atua como antioxidante, aumentando a vida do filme de $\mathrm{MoS}_{2}$. Yamamoto et al. [70] avaliaram o desempenho do grafite como aditivo em óleo e o seu efeito combinado com o MoDTC. O menor atrito alcançado foi com uma combinação de grafite, MoDTC e um dispersante. $O$ valor de coeficiente de atrito alcançado nos experimentos foi de 0,04 .

\subsubsection{Influência da topografia}

A topografia das superficies, em todas as escalas de magnitude, contém características que influenciam o atrito, o desgaste e a lubrificação [16]. Existem dois tipos fundamentais de características de especial relevância para o atrito e o desgaste [16].

- Defeitos em escala atômica que oferecem efeitos catalíticos para a reação dos lubrificantes com as superfícies desgastadas.

- A rugosidade da superfície que limita o contato entre os sólidos em frações pequenas da área nominal total.

Os defeitos em escala atômica estão relacionados, principalmente, a reatividade da superfície que já foi tratada na seção 2.4.1. Por isto, esta seção irá tratar apenas dos efeitos ligados a rugosidade das superfícies.

Kubiak et al. [71] avaliaram a influência da rugosidade na formação de tribofilme a partir de ZDDP. Eles concluíram que o tribofilme se forma mais rápido e demanda menos energia para sua formação em uma superfície gerada por fresamento ( $\mathrm{Sa}=$ 3,56 $\mu \mathrm{m})$ do que em uma superfície retificada $(\mathrm{Sa}=0,17 \mu \mathrm{m})$. As curvas que mostram a dissipação de energia por ciclo para a amostra fresada (Sup.2) e para amostras retificadas (Sup.4) estão ilustradas na figura 20. 


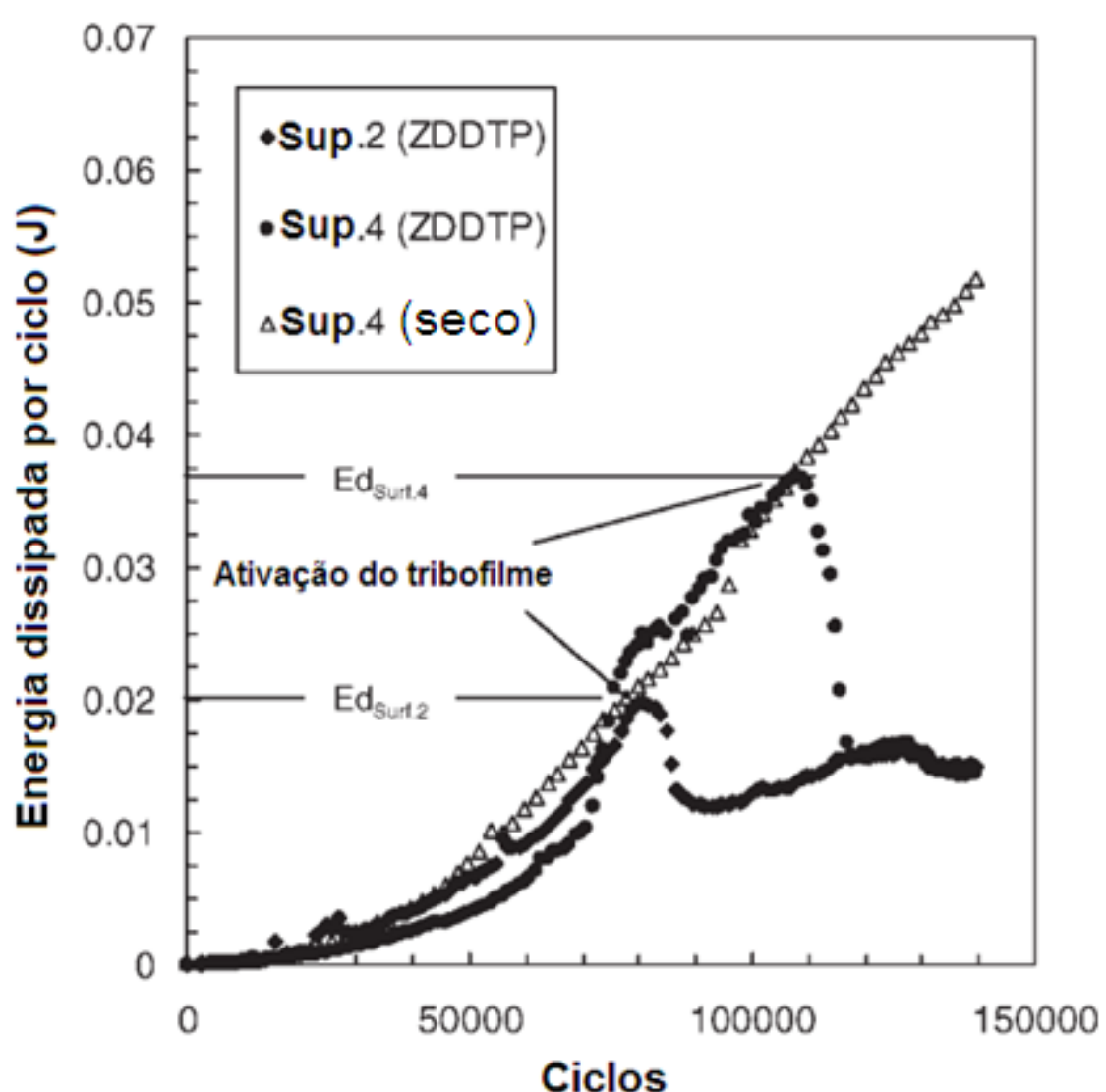

Figura 20 - Energia dissipadas por ciclo em um ensaio esfera contra plano para a ativação do ZDDP em superfícies fresadas (Sup.2) e retificadas (Sup.4) [71].

Acero [26] avaliou, em seu trabalho de mestrado, a influência da topografia da superfície no comportamento tribológico de um sistema esfera contra disco lubrificado com um óleo totalmente formulado que possuía MoDTC na sua formulação. Seus resultados mostraram que tanto a rugosidade quanto a orientação das características da topografia influenciam na ativação do MoDTC e consequentemente no coeficiente de atrito do tribossistema. Nos testes realizados com um disco liso ( $\mathrm{Sa}=0,05$, lixada) a ativação do MoDTC não ocorre em nenhuma das 4 amostras ( 2 testadas na direção paralela a do lixamento e 2 testadas na direção perpendicular a do lixamento). Nos ensaios realizados com discos rugosos ( $\mathrm{Sa}=0,28$, retificada) as amostras testadas na direção perpendicular à da retificação apresentaram redução do atrito devido a ativação do MoDTC enquanto as amostras testadas na direção paralela a da retificação não apresentaram ativação do MoDTC. Os resultados de Acero [26] estão ilustrados nos gráfico da figura 21. 

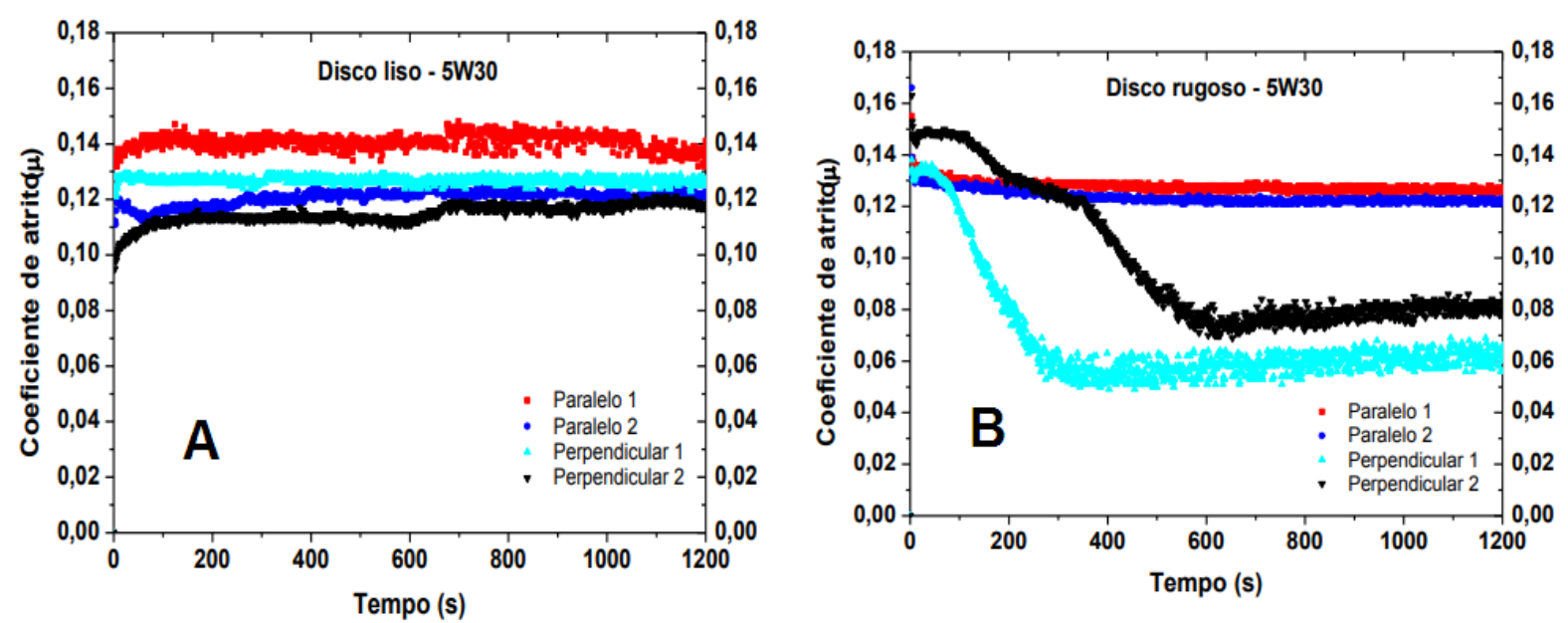

Figura 21 - Curvas de atrito de ensaios esfera contra disco lubrificados com óleo totalmente formulado 5W30. Gráfico A apresenta os ensaios com discos lisos $(\mathrm{Sa}=0,05)$ e o gráfico B os ensaios com discos rugosos $(\mathrm{Sa}=0,28)[26]$.

\subsection{Tribotestes na simulação do sistema anel/cilindro}

Segundo Zum Gahr [72] os testes tribológicos (tribotestes) compreendem o estudo do atrito, lubrificação e do desgaste. Os tribotestes são simplificações de um tribossistema real que podem ser executadas em ensaios de bancada. A norma DIN 50322 (1979) classifica estas simplificações em 6 níveis, sendo o primeiro a situação real. A figura 22 mostra uma representação gráfica desta classificação. 


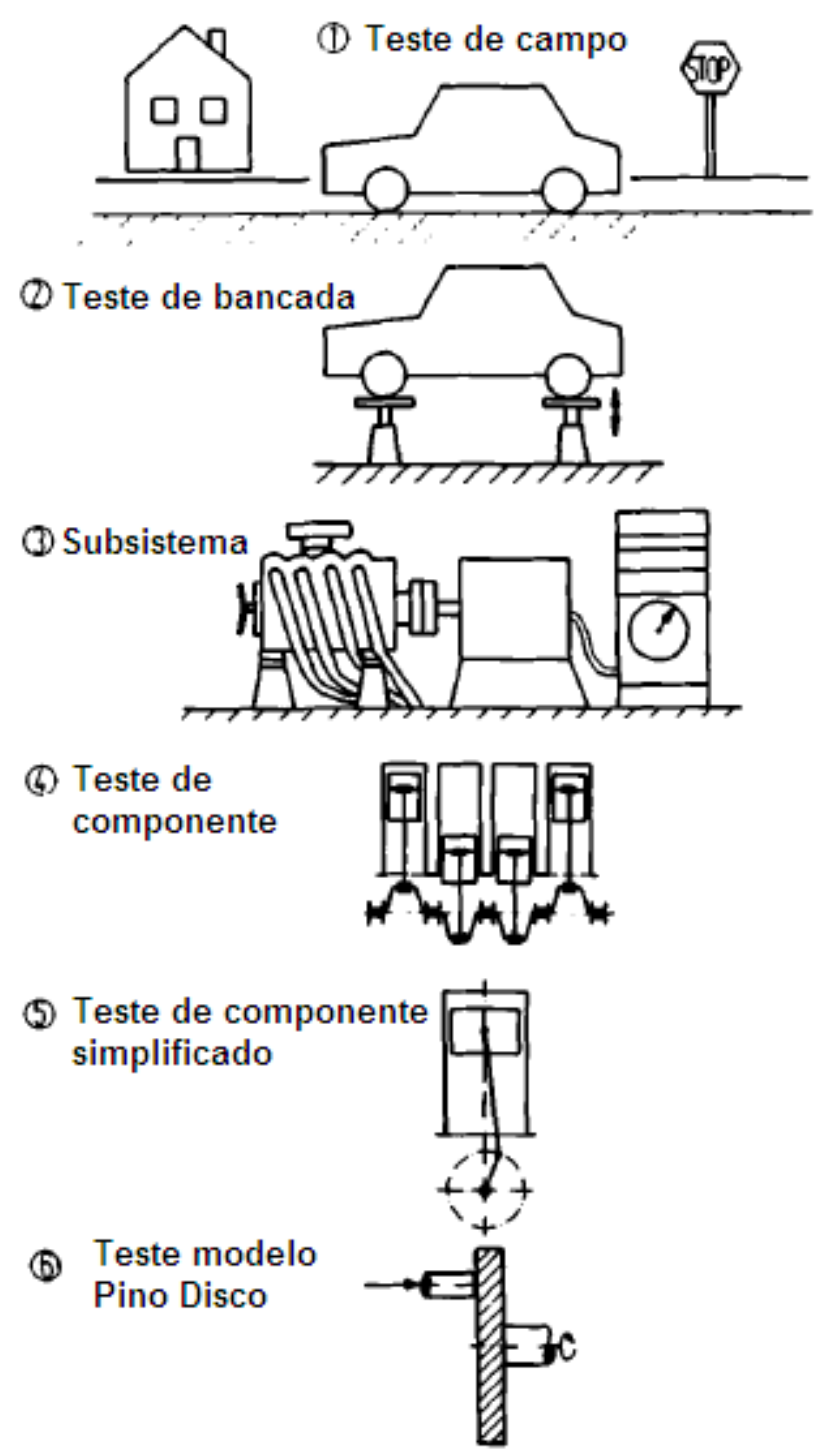

Figura 22 - Classificação dos diferentes tipos de tribotestes de acordo com a norma DIN 50322 (1979) [72].

As principais respostas de um triboteste são o atrito e o desgaste. É, geralmente, a partir deles que uma análise mais aprofundada é feita para descrever os fenômenos que governaram o comportamento daquele tribossistema.

A simulação, empregando tribotestes, é complexa porque envolve muitos fatores. Segundo Blau [1] existem aspectos mecânicos, térmicos, de materiais e triboquímicos que devem ser considerados. Ele ainda salienta que apesar da grande importância do último no desempenho do sistema anel/cilindro maior atenção tem sido dada aos três primeiros. 
Lee [73] divide os parâmetros que devem ser considerados no modelamento de um triboteste em 2 grupos principais:

- Componentes: geometria (perfil da superfície e acabamento), materiais e lubrificante.

- Condições do sistema: velocidade, carga, temperatura e, em tribômetro reciprocativos, amplitude do movimento.

A tabela 2 mostra um levantamento feito por Czichos [74] dos fatores envolvidos no delineamento de um triboteste.

Tabela 2 - Fatores importantes que devem ser considerados no delineamento de um triboteste [adaptado de 74].

\begin{tabular}{|l|l|}
\hline \multicolumn{2}{|c|}{ Fatores importantes que devem ser considerados no delineamento de um } \\
triboteste
\end{tabular}

Modelar um teste efetivo de desgaste requer atenção para os seguintes detalhes [75]:

1) A pressão de contato e a geometria devem replicar a aplicação. Aumentar a pressão de contato para acelerar o teste pode alterar o mecanismo de desgaste predominante para um que não ocorre em situação real. 
2) Produzir o tipo correto de movimento é importante para conduzir simulações efetivas (por exemplo: fretting, deslizamento reciprocativo, deslizamento unidirecional e etc.).

3) A temperatura e a atmosfera devem ser replicadas apropriadamente.

4) O estado de contaminação do lubrificante ou do ambiente deve ser replicado. Por exemplo: pode ser melhor usar óleos contaminados ao invés de óleo novo quando se está testando materiais para camisas.

5) As amostras devem ser examinadas para assegurar modos de desgastes semelhantes.

6) A natureza das partículas de desgaste também pode auxiliar no aferimento da simulação.

A tabela 3 mostra as informações sobre os fatores que podem afetar 0 coeficiente de atrito e por isto devem ser cuidadosamente considerados. 
Tabela 3 - Fatores que podem afetar o atrito dependendo das condições de contato [74].

\begin{tabular}{|c|c|}
\hline \multicolumn{2}{|c|}{ Fatores que podem afetar $\mathrm{o}$ atrito dependendo das condições de contato } \\
\hline Categoria & Fator \\
\hline \multirow{5}{*}{ Mecânico } & Geometria do contato: macro, micro, nano \\
\hline & Carga e distribuição da pressão de contato em várias escalas \\
\hline & Histórico do carregamento \\
\hline & $\begin{array}{l}\text { Dinâmica do Sistema: vibrações, rigidez, amortecimento, } \\
\text { histerese }\end{array}$ \\
\hline & Tipo de movimento e perfil de velocidade \\
\hline \multirow{9}{*}{ Materiais } & Material do par \\
\hline & Composição e pureza \\
\hline & Características adesivas \\
\hline & Microestrutura \\
\hline & Propriedades elásticas e plásticas \\
\hline & Gradientes de propriedades nas regiões próximas a superfície \\
\hline & Propriedades termofísicas \\
\hline & Método de geração das superfícies \\
\hline & Tensões residuais nas regiões próximas as superfícies \\
\hline \multirow{6}{*}{$\begin{array}{l}\text { Efeitos } \\
\text { térmicos }\end{array}$} & Aquecimento pelo atrito \\
\hline & Fontes de aquecimento externas \\
\hline & Elasticidade termoelástica \\
\hline & Transformações de fases induzidas termicamente \\
\hline & Ativações triboquímicas \\
\hline & Choques térmicos \\
\hline \multirow{6}{*}{ Lubrificação } & Quantidade e modo de fornecimento de lubrificante \\
\hline & Regime de lubrificação \\
\hline & Propriedades do lubrificante \\
\hline & Formulação do lubrificante \\
\hline & Deterioração do lubrificante \\
\hline & Filtragem e limpeza \\
\hline \multirow{7}{*}{ Triboquímica } & Umidade relativa \\
\hline & Reatividade da superfície/catálise \\
\hline & Limpeza \\
\hline & Composição da atmosfera próxima \\
\hline & Tribopolimerização \\
\hline & Formação de polímero induzida pelo atrito \\
\hline & Formação de filmes de óxidos \\
\hline \multirow{6}{*}{$\begin{array}{c}\text { Terceiro } \\
\text { corpo }\end{array}$} & Formação de partícula transferida \\
\hline & $\begin{array}{l}\begin{array}{l}\text { Propriedades mecânicas } \\
\text { triboformadas }\end{array} \\
\text { e }\end{array}$ \\
\hline & Concentração e aglomeração de partículas de desgaste \\
\hline & Tamanho, forma e morfologia das partículas \\
\hline & Contaminantes externos \\
\hline & Fluxo do terceiro corpo dentro e fora do contato \\
\hline
\end{tabular}


Alguns dos parâmetros de ensaio que tem forte influência no desempenho de um tribossistema que está sendo simulado através de um tribotestes são: rugosidade, carga, velocidade, temperatura e tribofilmes [74].

"Se a pressão de contato é baixa, se os materiais em contato são relativamente duros ou se um filme espesso de lubrificante está presente, então as características iniciais da superfície podem ser preservadas por um longo período de deslizamento e pode continuar afetando o atrito. Se, contudo, as pressões de contato são altas ou se uma ou ambas as superfícies são relativamente moles, as características iniciais da superfície irão rapidamente desaparecer. Ao invés disso, a morfologia da superfície será determinada pelas propriedades de desgaste do material e outros fatores, como a formação de partículas de desgaste e de filmes de transferência [74]."

O efeito da carga deve ser considerado sob três perspectivas segundo Blau [75]:

1- Presença de filmes: filmes adsorvidos, filmes de óxidos e outros produtos de reação podem afetar o atrito se a força tangencial ou a taxa de desgaste é insuficiente para removê-los.

2- Efeitos da pressão de contato na microestrutura: As propriedades mecânicas dos microconstituintes próximos a superfície são influenciadas pela pressão de contato. A resistência ao cisalhamento dos sólidos pode ser alterada aumentando a pressão (Ex: encruamento no caso de metais ou efeitos da pressão hidrostática na tensão de cisalhamento). A deformação dos materiais durante o deslizamento pode alterar a orientação cristalográfica para facilitar o cisalhamento ou para induzir transformações de fases.

3- Transições na severidade do desgaste: A severidade do desgaste é fortemente influenciada pela carga. Alterações na severidade do desgaste podem alterar drasticamente $O$ atrito.

A velocidade pode influenciar no regime de lubrificação, que tem forte influência no coeficiente de atrito. Se a velocidade for alterada sem que haja alteração no regime de lubrificação, o aumento da velocidade pode provocar aumento da temperatura no contato. 
Os principais efeitos da temperatura no atrito surgem da sua influência nos seguintes fatores [74]:

- A resistência ao cisalhamento da superfície dos materiais.

- A viscosidade dos lubrificantes líquidos e sólidos.

- A tendência dos materiais para reagir com o ambiente que o cerca para formar filmes.

- A tendência dos lubrificantes líquidos formulados para mudar sua composição química (Ex: oxidação ou mudança de peso molecular) é dependente da temperatura e do tempo de exposição.

- A habilidade do metal ou liga de encruar ou alterar sua estrutura e propriedades.

- A tendência do material para aderir e transferir para o contra-corpo.

- A habilidade da superfície para adsorver ou dessorver contaminantes ou aditivos.

Blau [76] expõe oito tipos de filmes que podem alterar o comportamento do atrito de um tribossistema. Estes podem ser vistos na tabela 4.

Tabela 4 - Oito filmes que afetam o atrito [76].

\begin{tabular}{|c|l|}
\hline \multicolumn{2}{|c|}{ Oito filmes que afetam o atrito } \\
\hline Tipo de filme & \multicolumn{1}{|c|}{ Fontes ou condiçães de ocorrência } \\
\hline Adsorvidos & $\begin{array}{l}\text { Umidade do ar; contaminantes trazidos pelo ar como } \\
\text { moléculas de hidrocarbonetos. }\end{array}$ \\
\hline Resíduos & $\begin{array}{l}\text { Remanescentes do solvente ou outro processo de } \\
\text { limpeza. }\end{array}$ \\
\hline Polímeros de fricção & $\begin{array}{l}\text { Filmes poliméricos que formam no contato devido a } \\
\text { ação catalítica da superfície do material. }\end{array}$ \\
\hline Óxidos & Comuns em materiais metálicos expostos ao ambiente. \\
\hline Sulfetos & $\begin{array}{l}\text { Podem ser formados a partir da reação de aditivos dos } \\
\text { lubrificantes. }\end{array}$ \\
\hline Camadas fundidas & $\begin{array}{l}\text { Finos filmes fundidos causados pelo aquecimento } \\
\text { intenso pelo atrito. }\end{array}$ \\
\hline $\begin{array}{c}\text { Segregações } \\
\text { superficiais }\end{array}$ & $\begin{array}{l}\text { Camadas finas de material transferido do corpo para o } \\
\text { contra-corpo. } \\
\text { superfície para formar depósitos (Ex: dezincificação). }\end{array}$ \\
\hline
\end{tabular}

Quando se trata de simular o sistema anel/cilindro geralmente os ensaios em tribômetro são modelados para simular apenas a região do curso onde prevalece 0 
regime de lubrificação limítrofe. Esta simplificação é devido a configuração dos tribômetros que, na maioria dos casos, não estão aptos a atingir as velocidades de deslizamento normalmente encontradas no centro de curso.

Também é maior o interesse na região próxima ao ponto morto superior. Pois, é nesta região que ocorrem as condições mais severas de operação do sistema anel/cilindro (maior temperatura, pressão de contato e velocidade de deslizamento menor). Portanto, é no ponto morto superior que o anel, o cilindro e os aditivos formadores de tribofilme são mais solicitados em relação ao atrito e ao desgaste.

A norma ASTM G181 - 4 expõe outra limitação da simulação do sistema anel/cilindro em tribômetro que se refere à cinemática do anel ao longo do curso. Nos ensaios em tribômetro apenas o movimento de vai e vem do anel é simulado. Outros movimentos como rotação não são considerados. Além disto, a norma não fixa parâmetros de ensaio, criando um ensaio padrão. Esta padronização não é possível porque cada motor possui condições de operação e materiais particulares. O mesmo acontece com o óleo. Por isto, a norma sugere que cada triboteste deve ser adaptado ao motor que ele irá simular.

Segundo Blau [75] testar materiais candidatos a serem aplicados em componentes de motores de combustão interna tem historicamente tomado algumas rotas:

1. Substituição de componentes em motores reais submetidos ao uso diário.

2. Testar em motores instrumentados.

3. Testar em laboratório utilizando tribômetros com amostras relativamente simples.

Em geral, os novos materiais que estão sendo desenvolvidos para serem aplicados em motores de combustão interna, incluindo os óleos, passam primeiro por ranqueamento usando tribotestes. Estes testes usam como referência os resultados obtidos com os materiais já em uso consolidado. Caso o material seja aprovado nos tribotestes ele passará por testes em motores instrumentados e só depois nos veículos.

Esta rota de desenvolvimento que exige que os novos materiais necessitem ser testados em motores instrumentados e em alguns casos também em veículos ainda é importante devido às limitações, que já foram expostas nesta seção, que os tribotestes possuem em simular a condição real de operação de um motor de combustão interna. Além disto, como atrito e desgaste são propriedades sistêmicas 
eles podem influenciar e serem influenciados por fatores de operação do motor que foram subtraídos como forma de simplificação do triboteste.

Portanto, o delineamento de um triboteste para simular o sistema anel/cilindro de um motor de combustão interna deve ser extremamente criterioso para que a resposta obtida agregue conhecimento sobre o objeto em estudo (materiais dos componentes, revestimentos, aditivos do óleo e etc.), e para que o seus resultados possuam correlação satisfatória com os obtidos em motores instrumentados.

\subsection{Ferros fundidos usados na fabricação de blocos de motor}

Os ferros fundidos são ligas $\mathrm{Fe}-\mathrm{C}-\mathrm{Si}$, contendo ainda $\mathrm{Mn}$, $\mathrm{S}$ e $\mathrm{P}$, podendo adicionalmente apresentar elementos de liga diversos [77]. $O$ teor de carbono destas ligas geralmente é superior a $2 \%$ e o de silício varia entre 1 e $3 \%$ [78].

São ligas que apresentam na solidificação geralmente uma fase pró-eutética (austenita, grafita) e que se completa com uma solidificação eutética (austenita + grafita ou austenita + carbonetos) [77]. Durante a solidificação o máximo de carbono que pode ser dissolvido na austenita de uma liga de Fe-C é aproximadamente $2 \%$ [79]. A grafita da microestrutura dos ferros fundidos se forma do excesso de carbono que pôde ser dissolvido na estrutura da austenita.

Ferros fundidos são usados em muitas aplicações automotivas, uma das principais é em blocos de motor. Apesar do uso crescente de ligas de alumínio na fabricação de blocos para motores à gasolina, os ferros fundidos cinzentos (FC) continuam sendo predominantes na fabricação de blocos de motores à diesel [80]. As principais vantagens que fazem com que os ferros fundidos continuem sendo usados são seu baixo custo, alta resistência ao desgaste, amortecimento de vibrações e excelente usinabilidade [80]. Com a crescente tendência por motores menores e maiores pressões de combustão, os ferros fundidos vermiculares (FV) têm ganhado espaço em aplicações onde era usado o ferro fundido cinzento [80]. Em 2009 mais de 100.000 toneladas de blocos de motor de ferro fundido vermicular já eram produzidas por fabricantes como Audi, DAF, Ford, Hyundai, MAN, Mercedes, PSA, Volkswagen e Volvo [110]. 


\subsubsection{Ferro Fundido Cinzento}

Os ferros fundidos cinzentos apresentam percentual de carbono e silício que variam de 2,5 a $4 \%$ a 1 e $3 \%$, respectivamente. Para a maioria dos casos, a grafita se apresenta em forma de lamelas em uma matriz perlítica ou ferrítica [81, 82]

Os ferros fundidos cinzentos são empregados em larga escala pelas suas propriedades de fundição e baixo custo relativo [83].

- Fácil fusão e moldagem;

- Boa resistência mecânica;

- Excelente usinabilidade;

- Boa resistência ao desgaste;

- Boa capacidade de amortecimento de vibrações.

Por apresentarem fratura de cor cinza, denominam-se, classicamente, ferros fundidos cinzentos [84]. Possuem a grafita na forma lamelar interconectada e isto Ihes garante boa condutividade térmica, já que a grafita é um bom condutor térmico. Entretanto, a grafita disposta desta forma reduz a resistência mecânica, a ductilidade e também a tenacidade do material, pois provoca descontinuidades na matriz, assim como efeitos de entalhe [84].

A concentração de tensão na ponta da grafita é tão alta que impossibilita deformações plásticas apreciáveis quando medidas em um ensaio de tração. Por isto, os ferros fundidos cinzentos não apresentam tensão de escoamento bem definida. Isto faz com que os ferros fundidos cinzentos tenham como principal propriedade destacada na sua classificação a resistência à tração. A tabela 5 traz ferros fundidos da classe 20 até a classe 60 com seus respectivos valores de resistência à tração.

Tabela 5 - Resistência à tração dos ferros fundidos cinzentos segundo a norma ASTM A 48 [85].

Resistência à tração

\begin{tabular}{ccc}
\hline Classe ASTM & MPa & ksi \\
\hline 20 & 140 & 20 \\
30 & 205 & 30 \\
35 & 240 & 35 \\
40 & 275 & 40 \\
50 & 345 & 50 \\
60 & 415 & 60
\end{tabular}


A grafita no bloco de ferro fundido funciona como lubrificante sólido durante a usinagem assim como na operação do motor [86]. A grafita oferece baixa tensão de cisalhamento entre as suas lamelas devido as fracas ligações de Van Der Waals associada a boa capacidade de carga no sentido perpendicular ao plano das lamelas e, por isto, pode atuar como lubrificante sólido. A figura 23 mostra o mecanismo de lubrificação sólida da grafita.

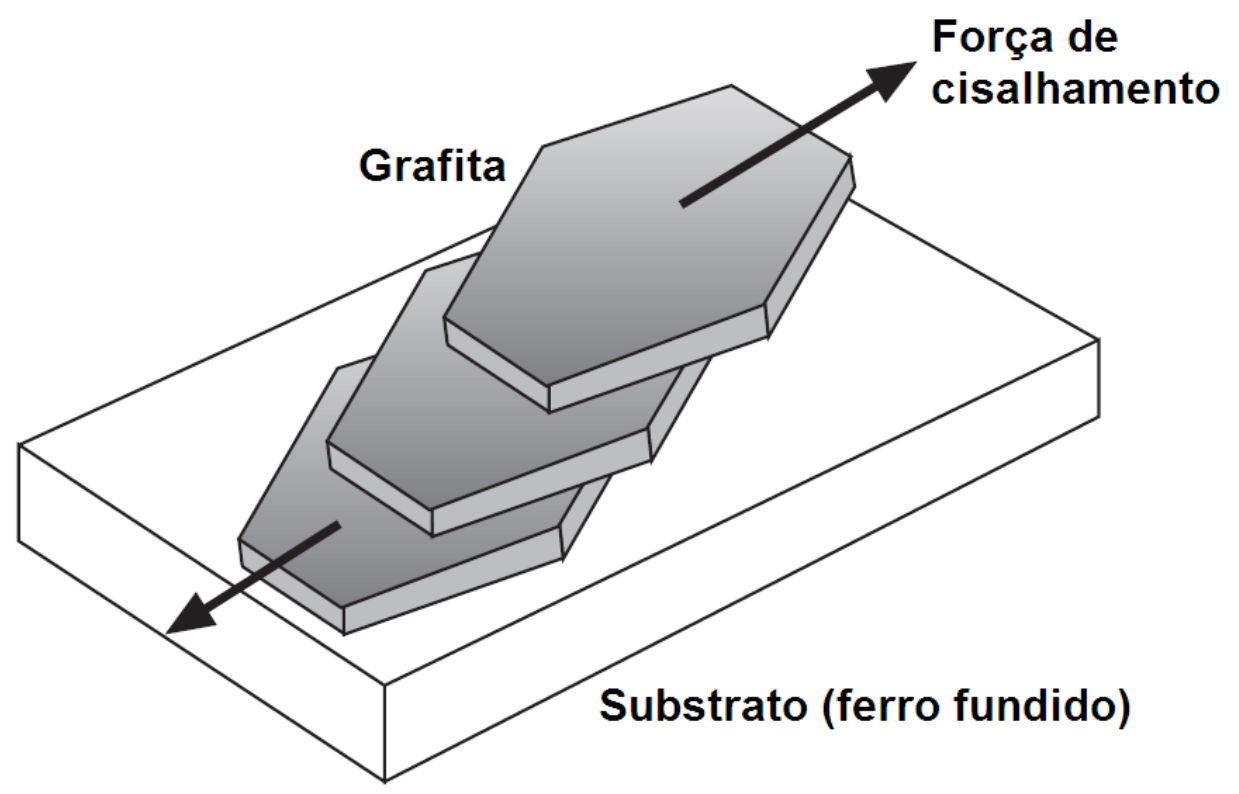

Figura 23 - Mecanismo de lubrificação sólida. As lamelas da grafita cisalham umas sobre as outras sob força de atrito. O baixo coeficiente de atrito aparece ao longo do plano basal sob tensões de cisalhamento [86].

O cristal de grafita escorrega com facilidade ao longo do seu plano basal mesmo sob pequenas forças de cisalhamento. A grafita reduz o atrito nas ferramentas durante a usinagem [86]. A natureza frágil da grafita e a descontinuidade que ela promove na matriz fazem com que os cavacos sejam curtos [86]. Estas características fazem com que o ferro fundido cinzento tenha uma alta usinabilidade e isto permite altas precisões dimensionais [86]. A grafita também atua como lubrificante sólido prevenindo o desgaste adesivo severo entre os anéis de pistão e o cilindro mesmo em condições de lubrificação limítrofe [86]. 


\subsubsection{Ferro Fundido Vermicular}

Os ferros fundidos vermiculares apresentam percentual de carbono e silício que variam de 3,1 a $4 \%$ e 1,7 a 3\%, respectivamente. As grafitas apresentam-se em forma de verme. Ainda, algumas grafitas, menos de $20 \%$, apresentam-se em forma de nódulos [81]. A matriz destes materiais, de modo similar ao ferro fundido cinzento, podem ser ferrítica ou perlítica [81, 82].

O ferro fundido vermicular é um material intermediário entre o ferro fundido cinzento e o ferro fundido nodular [83] quando consideradas suas propriedades mecânicas. 0 formato da grafita também pode ser considerado como intermediário entre o ferro fundido cinzento e o nodular já que a maior parte das grafitas são lamelas com extremidades arredondadas, combinando assim características de grafitas lamelares com nodulares. Além disto, os ferros fundidos vermiculares podem conter até $20 \%$ das suas grafitas na forma nodular. Como suas grafitas concentram menos tensão que as grafitas lamelares dos cinzentos este tipo de ferro fundido consegue apresentar tensão de escoamento e alongamento e estas características são levadas em consideração na sua classificação segundo a norma ISO 16112, ilustrada na tabela 6 .

Tabela 6 - Propriedades físicas e mecânicas determinadas pela norma ISO 16112 para ferros fundidos vermiculares.

\begin{tabular}{lcccc} 
Classe & $\begin{array}{c}\text { Resistência à } \\
\text { tração, MPa }\end{array}$ & $\begin{array}{c}\text { Tensão de } \\
\text { escoamento, } \\
\text { MPa }\end{array}$ & $\begin{array}{c}\text { Alongamento } \\
\%\end{array}$ & $\begin{array}{c}\text { Módulo de } \\
\text { elasticidade, } \\
\text { GPa }\end{array}$ \\
\hline GJV-300 & $300-375$ & $210-260$ & $2,0-5,0$ & $130-145$ \\
GJV-350 & $350-425$ & $245-295$ & $1,5-4,0$ & $135-150$ \\
GJV-400 & $400-475$ & $280-330$ & $1,0-3,5$ & $140-150$ \\
GJV-450 & $450-525$ & $315-365$ & $1,0-2,5$ & $145-155$ \\
GJV-500 & $500-575$ & $350-400$ & $0,5-2,0$ & $145-160$
\end{tabular}

O limite de resistência a atração do ferro fundido vermicular é entre 1,5 e 2 vezes maior que a do ferro fundido cinzento e o módulo de elasticidade é cerca de 150 GPa enquanto o do ferro fundido cinzento é de cerca de $105 \mathrm{GPa}$ [80] Uma das estratégias usadas para aumentar a resistência a tração dos ferros fundidos vemiculares é elevar o grau de nodularidade das suas grafitas. Este 
comportamento pode ser observado através dos valores de resistência à tração e nodularidade apresentados na tabela 7 .

Tabela 7 - Propriedades dos ferros fundidos vermiculares em função da nodularidade [79].

\begin{tabular}{cccc} 
& \multicolumn{2}{c}{$\begin{array}{c}\text { Resistência à } \\
\text { tração }\end{array}$} & Alongamento \\
\cline { 2 - 3 } Nodularidade \\
\cline { 2 - 3 }$\%$ & $\mathbf{M P a}$ & $\mathbf{k s i}$ & $2-5$ \\
\hline $10-20$ & $320-380$ & $46-55$ & $2-6$ \\
$20-30$ & $380-450$ & $55-65$ & $3-6$ \\
$40-50$ & $450-500$ & $65-73$ &
\end{tabular}

Berns [87] elencou algumas diferenças entre os ferros fundidos vermiculares e os cinzentos e estão expostas na tabela 8.

Tabela 8 - Propriedades dos ferros fundidos vermiculares comparadas com as dos cinzentos [87]

Vermicular X Cinzento

- Maior resistência

- Maior ductilidade e rigidez

- Menor dependência da espessura da parede nas propriedades

- Maior resistência a oxidação

- Menor tendência a expansão em elevadas temperaturas

A condutividade térmica do ferro fundido vermicular é mais baixa que a do ferro fundido cinzento $\left(38 \mathrm{~W} \cdot \mathrm{m}^{-1} \cdot \mathrm{K}^{-1}\right.$ contra $\left.48 \mathrm{~W} \cdot \mathrm{m}^{-1} \cdot \mathrm{K}^{-1}\right)$ [80]. Com maior resistência à tração, maior módulo de elasticidade e menor condutividade térmica os blocos de ferro fundido vermicular podem ser projetados com menores espessuras dos que os fabricados em ferro fundido cinzento [80].

Adicionalmente, a grafita dos vermiculares difere da dos cinzentos em tamanho, forma e distribuição. Como já foi visto a grafita tem atuação como lubrificante sólido e estas diferenças também podem alterar o desempenho tribológico do cilindro. Por isso será feita a seguir uma abordagem mais detalhada da estrutura da grafita nestes dois tipos de ferros fundidos 


\subsubsection{Morfologia da grafita}

O grafite é um dos dois materiais formados apenas de carbono que estão presentes na natureza, o outro é o diamante. Enquanto o diamante tem uma estrutura cristalina cúbica de face centrada o grafite é composto por lâminas de grafeno nas quais os átomos de carbono estão arranjados na forma de colmeia [88]. No grafite, as ligações fortes do tipo sigma, dentro das lâminas, e as fracas, do tipo Pi, entre as lâminas produzem um material altamente anisotrópico [88]. As características da estrutura cristalina do grafite estão ilustradas na figura 26. Materiais grafíticos apresentam as conhecidas bandas $D$ em $1350 \mathrm{~cm}^{-1}$ e $\mathrm{G}$ em $1582 \mathrm{~cm}^{-1}$ no espectro Raman [68,69]. Segundo Reich et al. [112] a razão entre intensidade dos picos $D\left(I_{D}\right)$ e $\left(I_{G}\right)$ pode indicar o tamanho dos cristalitos e/ou nível de desordem. A relação $I_{D} / I_{G}$ é diretamente proporcional ao nível de desordem e inversamente proporcional ao tamanho dos cristalitos e ao grau de grafitização [113]. A figura 24 traz um espectro Raman mostrando os picos D e G característicos da grafita.

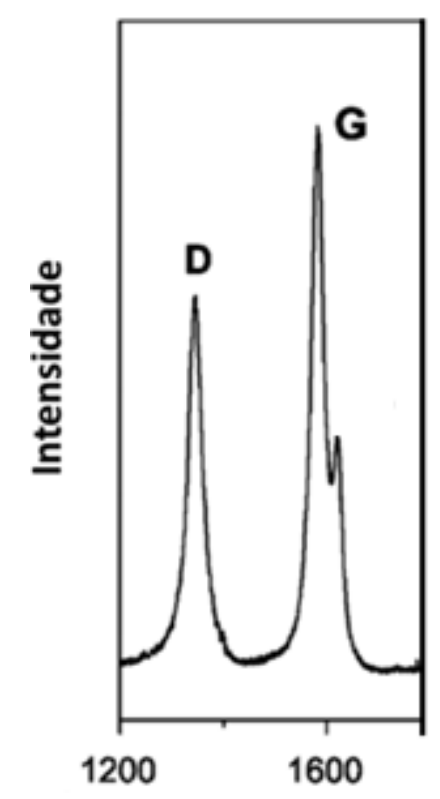

Figura 24 - Espectro Raman da grafita [adaptado de 7]

A grafita é um microconstituinte à base de grafite que se forma durante a solidificação dos ferros fundidos. 
Dependendo da composição química e da taxa de resfriamento, três tipos principais de grafitas podem se formar durante a solidificação de ligas de ferro fundido: lamelar, nodular e vermicular [78]. Cada uma destas destras grafitas está exemplificada na figura 25.
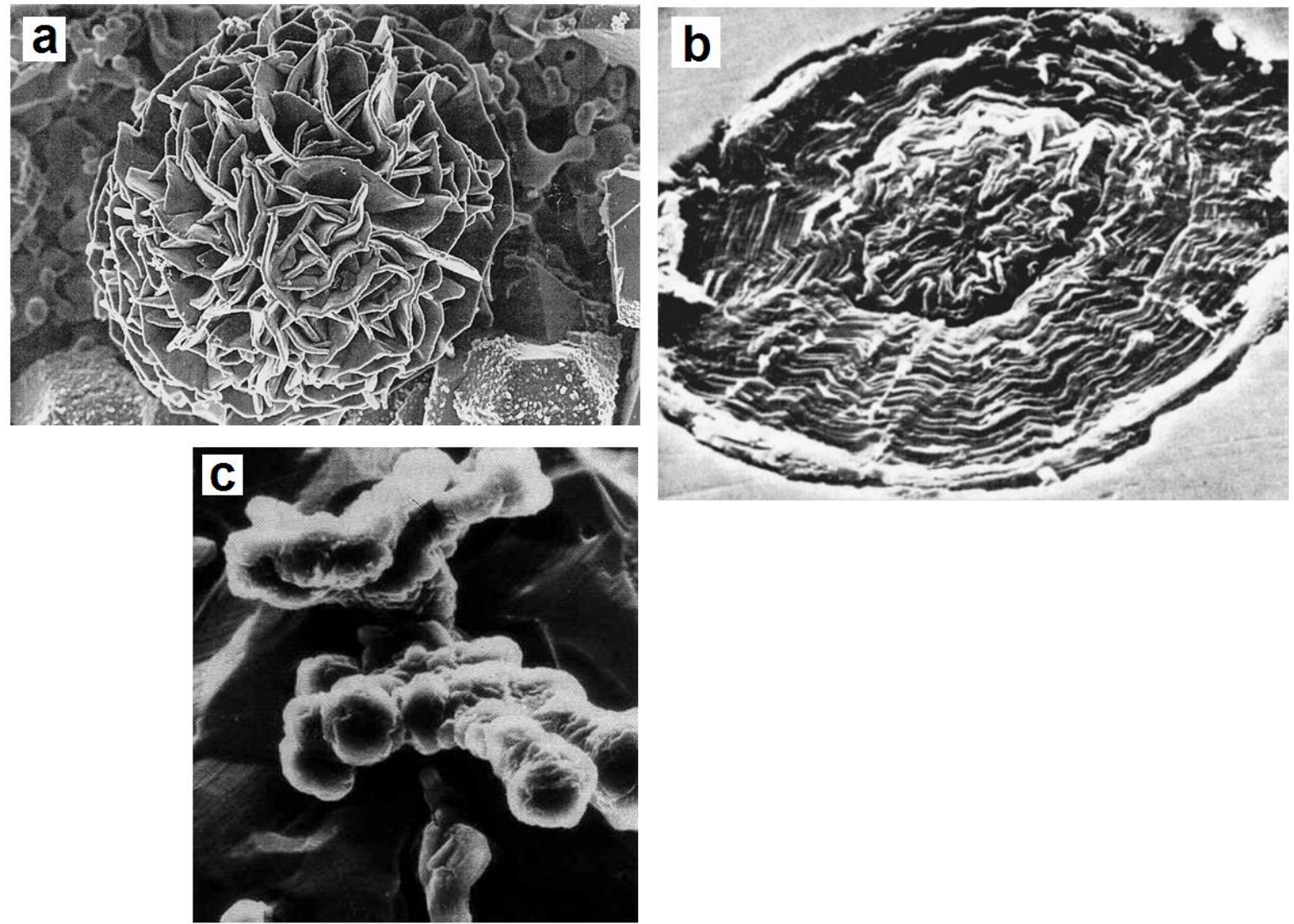

Figura 25 - a) grafita lamelar [90], b) grafita nodular [90], c) grafita vermicular [91].

Uma ampla análise da literatura associada a experimentos de solidificação interrompida confirmou que os blocos básicos dos agregados de grafite que cristalizam a partir ligas de ferro e carbono fundidas são plaquetas hexagonais facetadas de grafite geradas pelo crescimento de lamelas de grafeno [88], esta estrutura é idêntica a do grafite e também pode ser representada pela figura 26. 

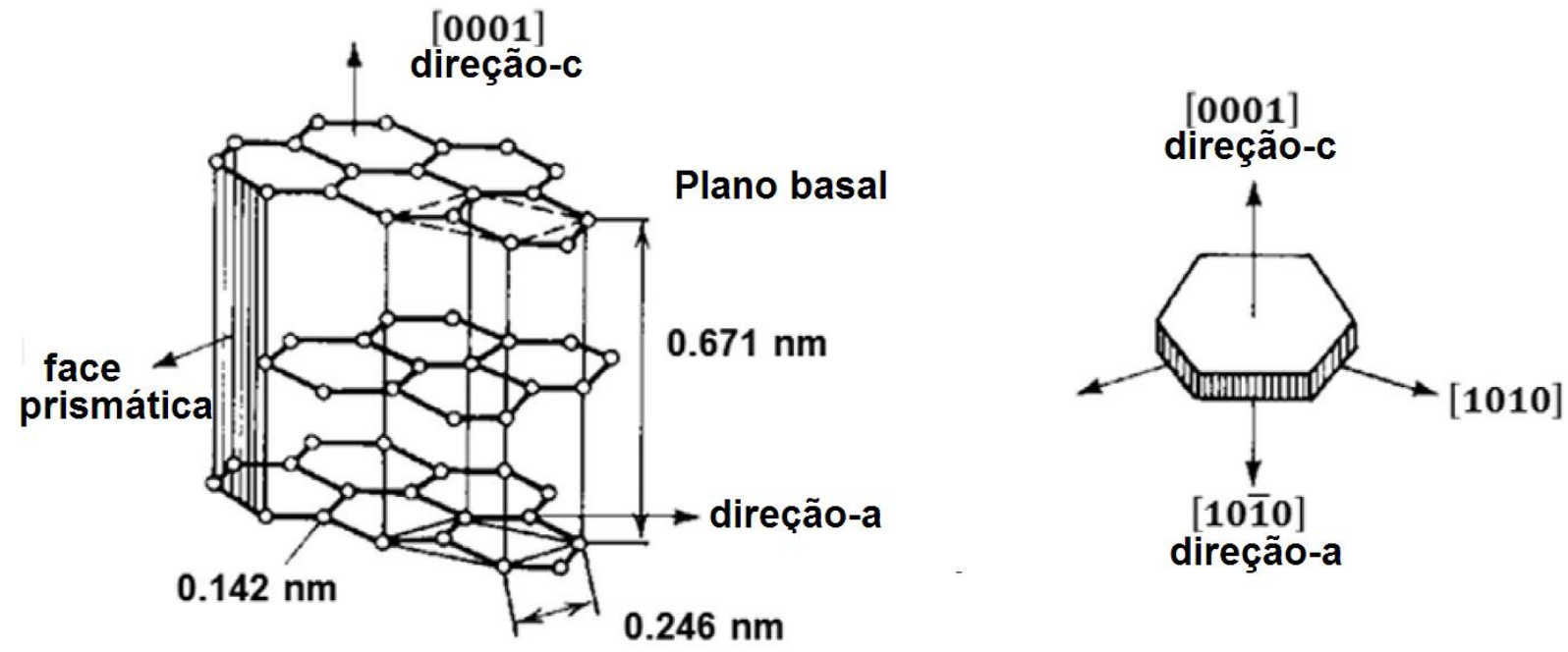

Figura 26 - Estrutura cristalográfica da grafita [92].

O crescimento da grafita no ferro fundido começa com a formação de uma camada bidimensional com apenas um átomo de espessura de grafite cristalino (lâmina de grafeno) que pode crescer facilmente na direção a [89]. Para produzir lâminas multicamadas (lamela de grafita), as camadas de grafeno precisam também crescer na direção na direção $c$ [89]. Há estudos que sugerem [88, 93] que, devido às impurezas com atividade nas superfícies $(\mathrm{S}, \mathrm{O}, \mathrm{N})$ serem adsorvidas nas bordas insaturadas das plaquetas, o crescimento na direção a é parcialmente inibido e o crescimento na direção $c$ se torna mais provável [89].

A diferença entre os formatos das grafitas lamelar, vermicular e nodular se dá pela direção predominante que elas crescem durante a solidificação. A grafita lamelar cresce predominantemente na direção a. A grafita nodular cresce predominantemente na direção $c$. Já a grafita vermicular alterna seu crescimento nas duas direções.

Outra diferença importante entre as grafita lamelares e as vermiculares e nodulares foi exposta por Roviglione e Hermida [94] que, analisando imagens de grande ampliação obtidas usando um microscópio eletrônico de varredura (MEV), notaram que os elementos constitutivos das grafitas vermiculares e nodulares são pequenos aglomerados de cristais facetados altamente distorcidos e aleatoriamente distribuídos, com os planos basais formando as superfícies maiores e os planos prismáticos formando os menores. Os resultados também foram confirmados por 
difração de raios-x [89]. Esta característica presente nas grafitas vermiculares e nodulares pode ser observada na imagem da figura 27.

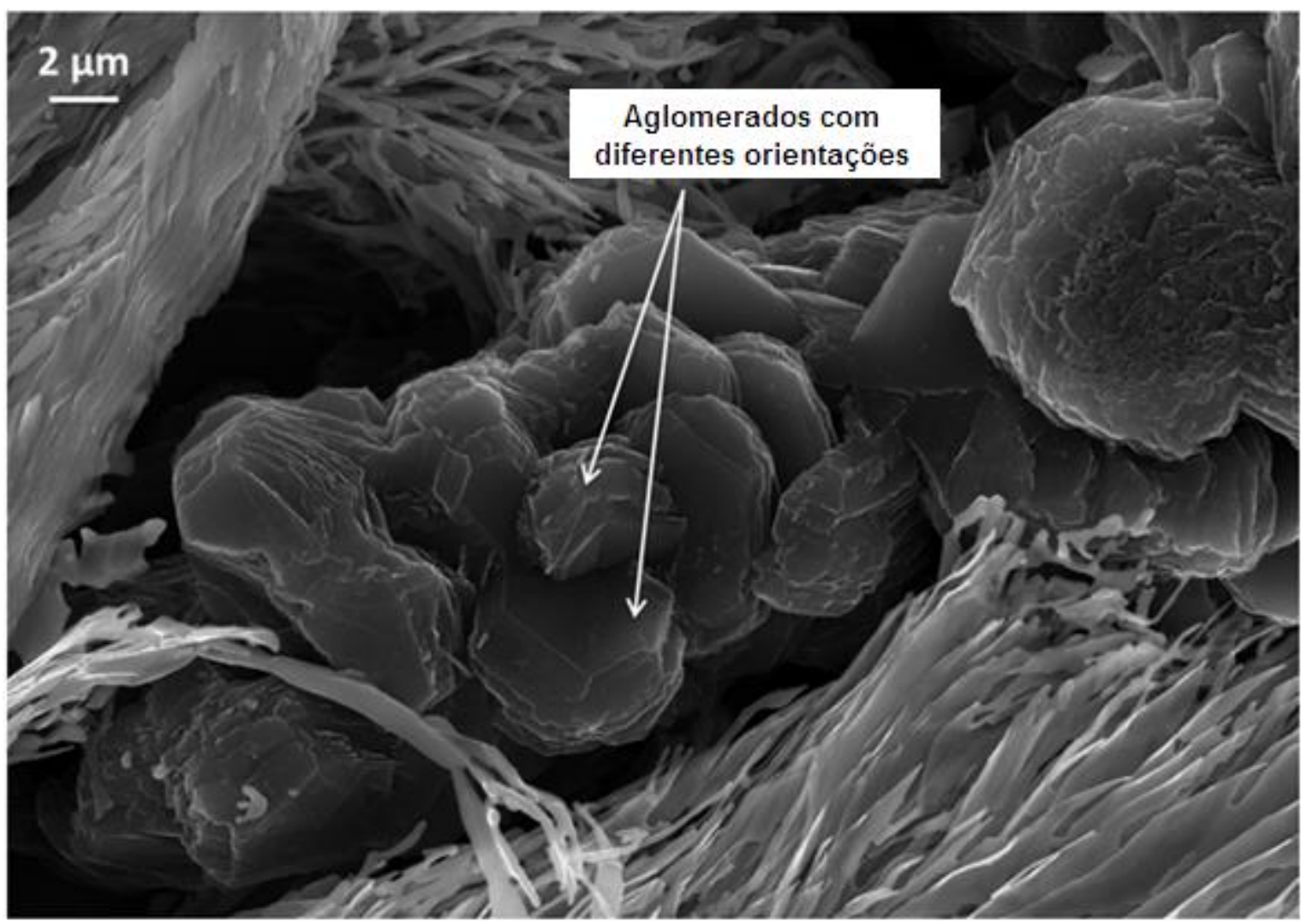

Figura 27 - Imagem obtida usando um MEV de uma de uma vermicular com ataque profundo de um Ferro fundido com $0,013 \%$ de magnésio. As setas indicam agregados com diferentes orientações formando uma grafita vermicular [89].

A grafita lamelar também se difere da vermicular em relação a sua interface com a matriz. Guesser [95] estudando a fratura por fadiga de ferros fundidos cinzentos e vermiculares mostrou que a interface entre o veio de grafita e a matriz no ferro fundido cinzento é bastante lisa e regular. Esta interface no ferro fundido vermicular é bastante rugosa. Isto significa que a grafita vermicular está mais ancorada na matriz.

\subsection{Aspectos tribológicos dos ferros fundidos}

Os ferros fundidos possuem características tribológicas específicas devido a presença da grafita na sua microestrutura. Dependendo das condições de operação do tribossistema ela pode atuar como lubrificante sólido ou ajudar na dissipação de 
calor reduzindo a tendência ao "scuffing" [77]. Segundo Zum Gahr [72] o efeito da grafita no desgaste é atribuído principalmente a sua atuação como lubrificante sólido ou fornecendo pequenos reservatórios para lubrificantes líquidos.

A grafita, presente na microestrutura dos ferros fundidos, só pode atuar como lubrificante sólido entre as superfícies porque, dependendo das condições de contato, ela tem a capacidade de ser extrudada para fora do material e formar um filme entre as superfícies em deslizamento. Ghasemi e Elmquist [96] e Franco [4] mostraram a ocorrência deste fenômeno promovendo indentações próximas a veios de grafita em ferros fundidos cinzentos. Isto está ilustrado na figura 28.

Obara [7] identificou a presença do tribofilme de grafita em superfície de motores de combustão interna quanto mapeava seus mecanismos de desgaste. Ele fez isto usando espectroscopia Raman que detecta a presença da grafita através da ocorrência dos picos D em $1350 \mathrm{~cm}^{-1}$ e $\mathrm{G}$ em $1582 \mathrm{~cm}^{-1}$ [68,69].

Isto significa que no tribossistema anel/cilindro as condições necessárias para a extrusão da grafita do interior da microestrutura para a interface de contato são satisfeitas e que este microconstituinte dos ferros fundidos tem alguma influência no desempenho triblógico deste tribossistema.

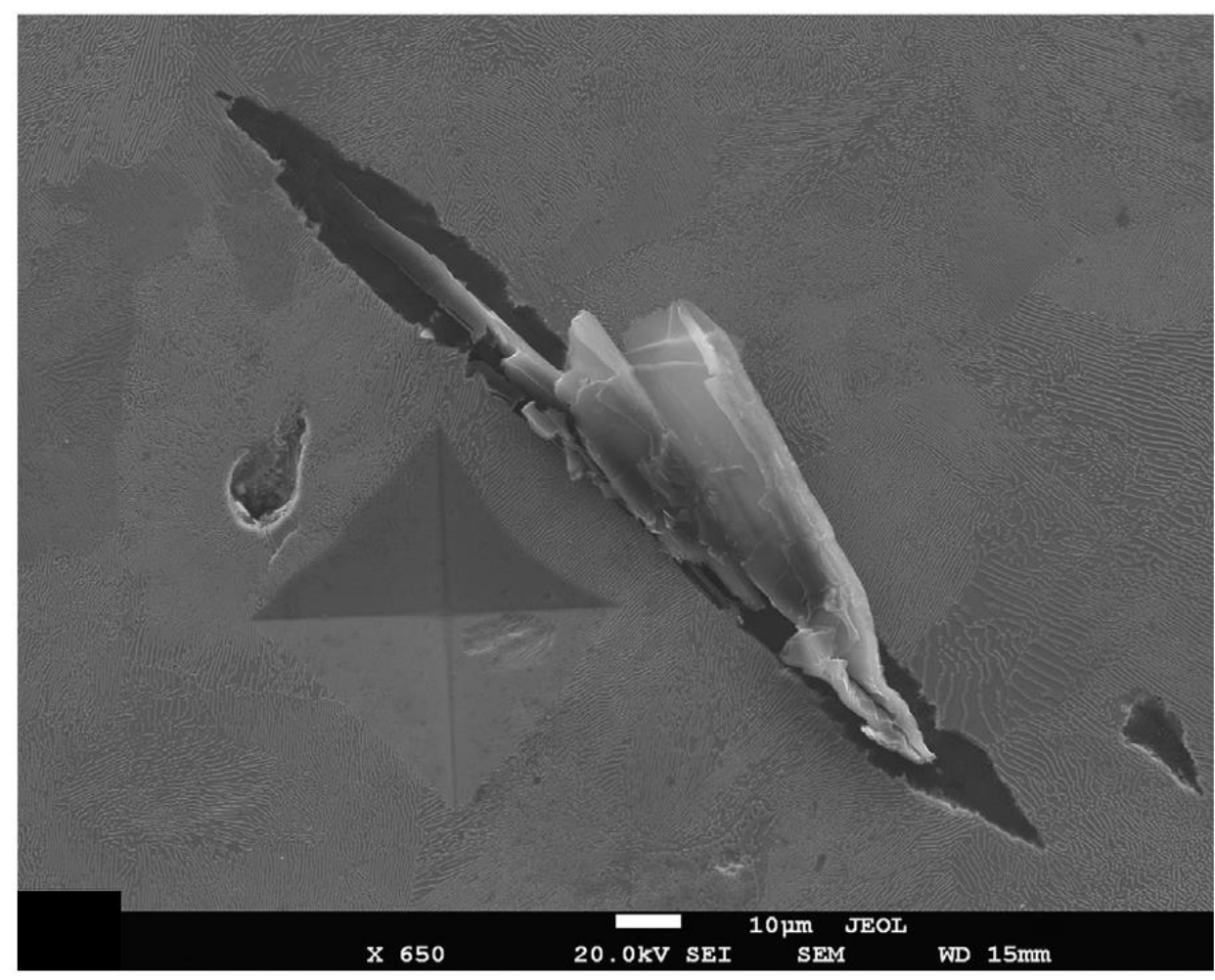

Figura 28 - Extrusão da grafita de uma amostra de ferro fundido cinzento devido a carga aplicada por uma indentação próxima ao veio [96] 
Hase [97], realizou tribotestes na configuração pino sobre bloco, à seco e com graxa, observando as superfícies em contato in situ usando um microscópio ótico e conseguiu observar o processo de extrusão da grafita. Ele concluiu que durante o processo inicial de deformação e fratura da superfície da amostra de ferro fundido a grafita é ejetada entre as superfícies em deslizamento como resultado da tensão gerada pelo atrito. Além disto, Hase [97] também concluiu que a forma da grafita influencia no processo de ejeção dela para a superfície e que a quantidade de grafita ejetada para a superfície foi maior nas amostras de ferro fundido cinzento do que nas amostras de ferro fundido nodular.

As conclusões de Hase [97] ainda não possuem verificação para o sistema anel/cilindro. Os resultados obtidos por ele ainda não foram verificados em condições que simulam a operação de um motor de combustão interna. Portanto, ainda não há na literatura trabalhos que evidenciem que há diferença de desempenho tribológico entre o ferro fundido cinzento e o vermicular quando aplicados em camisas ou blocos de motores devido a diferença de morfologia da grafita.

A resistência ao desgaste, como a resistência ao "scuffing", é afetada tanto pela forma da grafita quanto pela microestrutura da matriz [79]. Ferros fundidos vermiculares perlíticos sem elementos de liga tem aproximadamente metade do desgaste dos ferros fundidos cinzentos perlíticos não ligados quando submetidos a condições de abrasão [98]. Hrusovsky [99], concluiu que a profundidade média da trilha de desgaste em um triboteste na configuração pino sobre disco em condições brandas de desgaste e atrito foi $45 \%$ menor para o ferro fundido vermicular perlítico do que para o ferro fundido cinzento também perlítico [99].

Rac [102] mediu a resistência ao desgaste de ferros fundidos cinzentos e ferros fundidos nodulares em diferentes condições de carga e velocidade. $O$ ferro fundido cinzento se mostrou mais adequado para aplicações em altas velocidades e baixas cargas. Por outro lado, o ferro fundido nodular mostrou maior resistência ao desgaste em velocidades mais baixas e cargas mais altas [72]. Os resultados deste estudo estão representados no gráfico da figura 29. É importante lembrar que os ferros fundidos vermiculares podem ter até $20 \%$ de sua grafita na forma de nódulos [81]. Por isto, o comportamento tribológico das grafitas nodulares pode ser relevante também para os ferros fundidos vermiculares. 


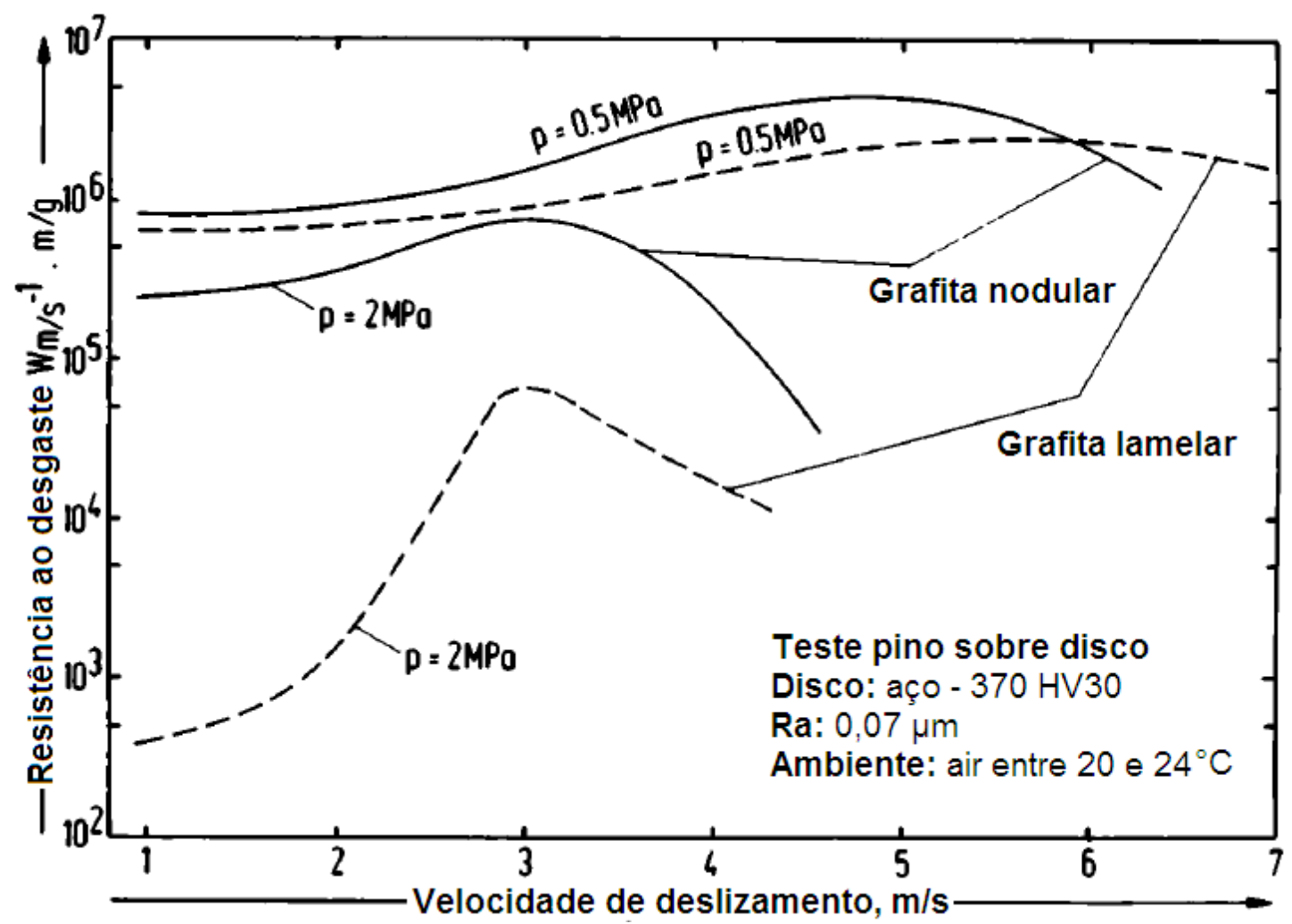

Figura 29 - Resistência ao desgaste de ferros fundidos nodulares e cinzentos medidas usando um ensaio de pino sobre disco à seco usando dois níveis de carga e variando a velocidade [102].

As grafitas podem atuar como concentradores de tensão fazendo com que trincas sejam nucleadas e propagadas a partir das suas extremidades [103]. Por isto, grafitas lamelares são mais prejudiciais para a resistência a fadiga dos ferros fundidos do que as grafita nodulares [72] ou vermiculares.

Por causa da presença dos veios de grafita na microestrutura do ferro fundido cinzento, grandes porções de material são arrancadas da superfície no regime de desgaste moderado (e às vezes até mesmo em regimes muito brandos de desgaste) [101]. A figura 30 mostra a seção transversal de uma amostra testada em condições de desgaste moderado e evidencia um exemplo uma porção de material removido devido influência da grafita. 


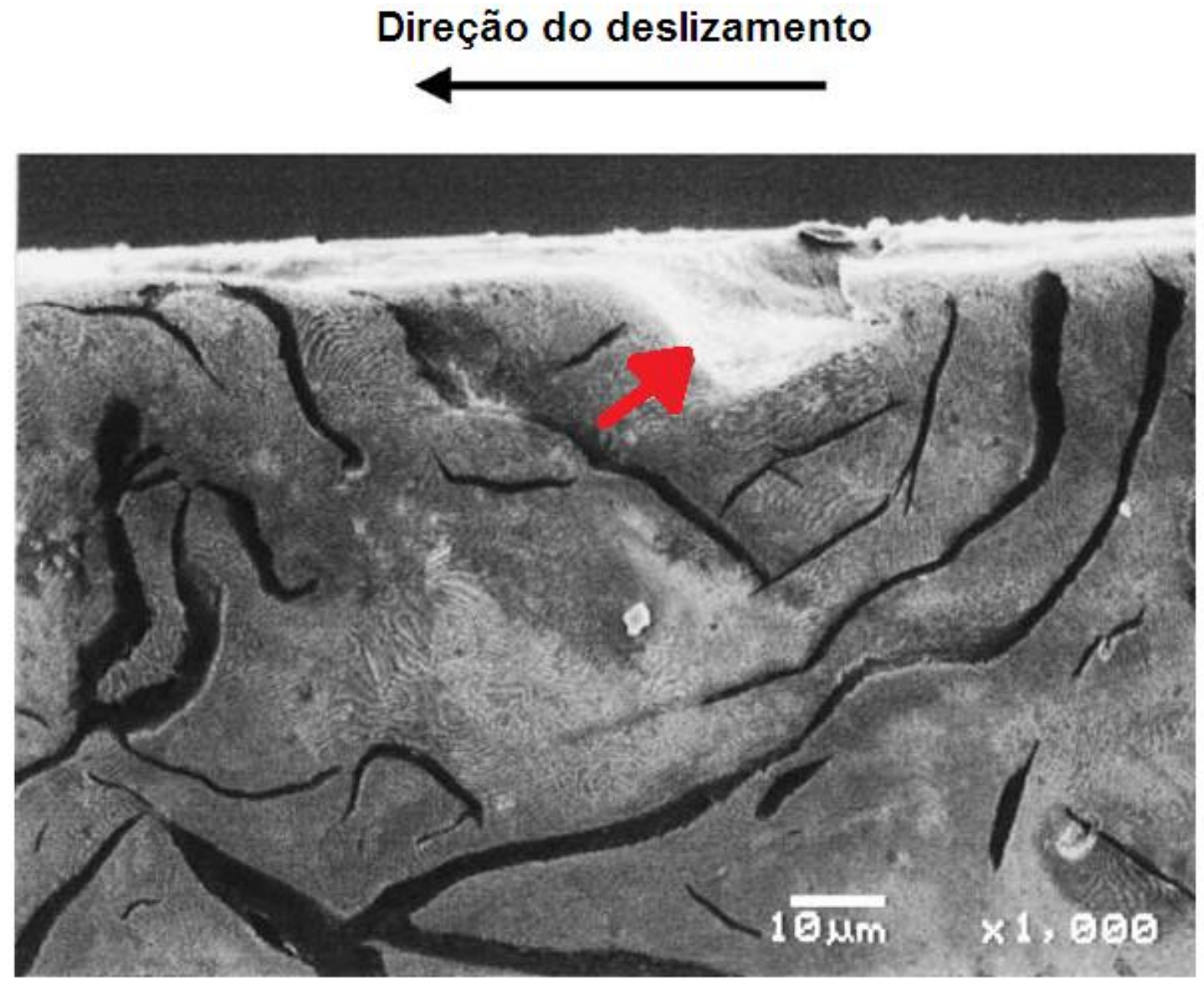

Figura 30 - Seção transversal de uma amostra de ferro fundido cinzento testado em um regime de desgaste moderado mostrando a região onde uma porção de material foi arrancada por influência da grafita. [97].

A morfologia da grafita influencia a condutividade térmica dos ferros fundidos e pode afetar sua resistência ao desgaste por fadiga de contato e a resistência ao desgaste por abrasão. Além disto, a morfologia da grafita também pode afetar sua capacidade de atuar como lubrificante sólido. Apesar da importância já evidenciada no desempenho do sistema anel/cilindro [7] não há, ainda, conhecimento consolidado sobre o mecanismo de atuação da grafita no sistema anel/cilindro, nem sobre quais fatores influenciam seu desempenho. Também não se conhece a influência da sua morfologia no desempenho deste sistema. Portanto, existe uma lacuna de conhecimento a respeito da tribologia dos ferros fundidos que este trabalho está se propondo a reduzir. 


\section{MATERIAIS E MÉTODOS}

\subsection{Materiais}

Para a execução deste trabalho foram usados usadas amostras provenientes de dois blocos de motores, um deles fabricado em ferro fundido cinzento e o outro em ferro fundido vermicular. Anéis de pistão de primeiro canalete e um óleo totalmente formulado usado em veículos de passeio também foram utilizados. A partir deste ponto as amostras de ferro fundido cinzento serão identificadas apenas como FC e as de ferro fundido vermicular como FV.

\subsubsection{Amostras de ferro fundido}

As amostras para ensaios tribológicos foram retiradas de dois blocos modelo Ford Griffin V8, com cilindros de $83 \mathrm{~mm}$ de diâmetro. Um dos blocos foi fundido com uma liga de ferro fundido cinzento e o outro de vermicular, como indicado na figura 31 e a suas dimensões são apresentadas na figura 32.

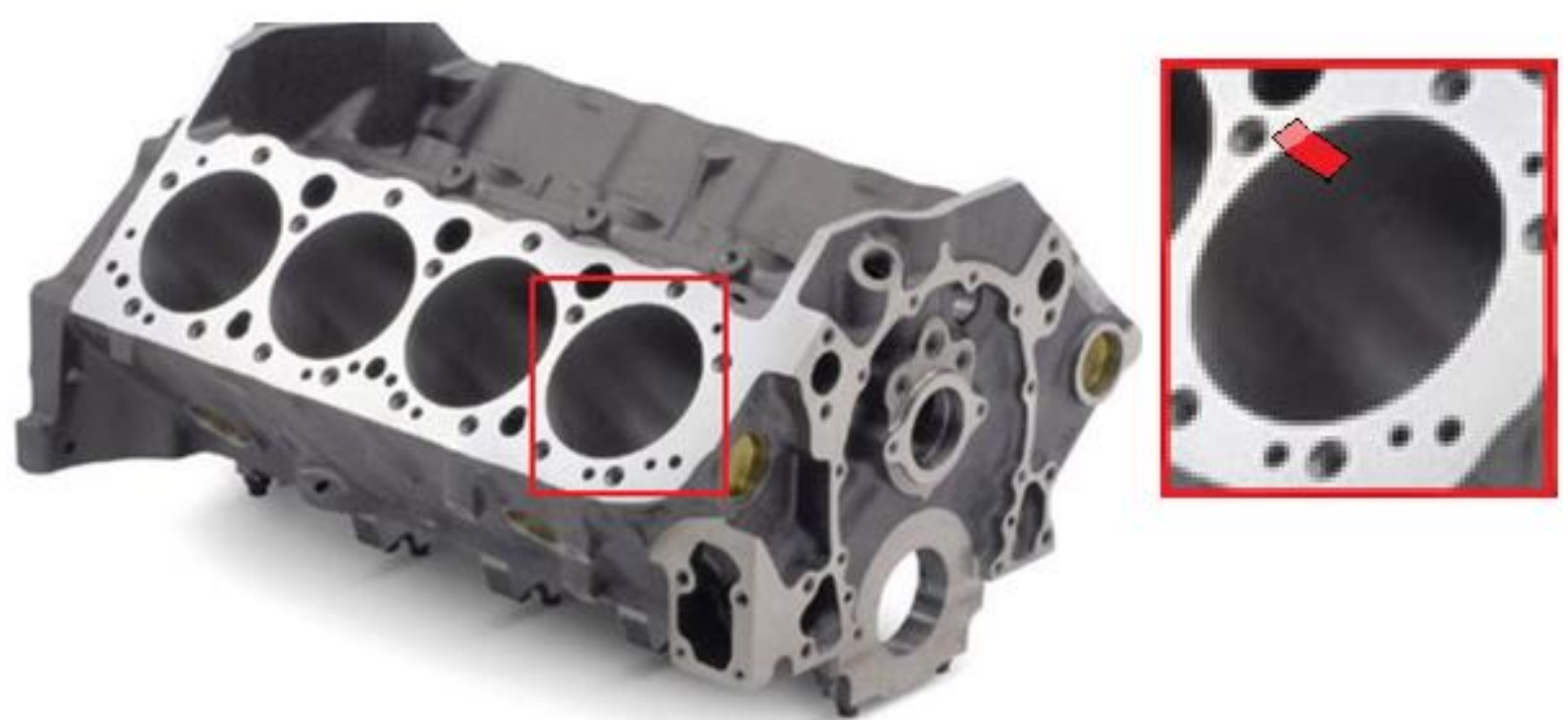

Figura 31 - Imagem ilustrativa da posição de retirada das amostras. 

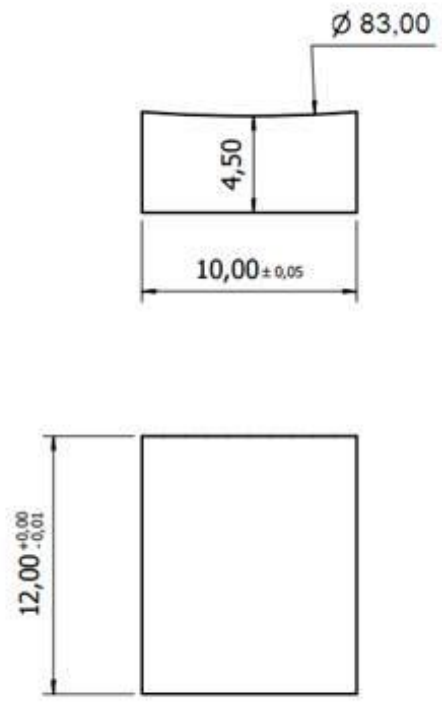

Figura 32 - Dimensões das amostras para ensaios em tribômetro usadas neste trabalho.

Foram confeccionadas, ao todo, 50 amostras como as da figura 32 para a realização dos ensaios deste trabalho. A maior parte delas foi descartada depois dos tribotestes por apresentarem desalinhamento entre $o$ anel e a amostra de cilindro provocando um contato não conforme. A grande quantidade de perda de amostras afetou a quantidade de tribotestes realizados. A intenção inicial é que cada condição tivesse, pelo menos, uma repetição, o que não foi possível para os ensaios com apenas uma gota de óleo e interrompidos. $O$ apêndice ao final deste trabalho descreve o processo de alinhamento do anel no porta-amostra e ilustra as dificuldades deste procedimento.

Para este trabalho foram retiradas amostras dos blocos de FC e FV para determinação das propriedades mecânicas e microestrutura. Estas amostras foram retiradas conforme o plano de controle de qualidade da Tupy, que é determinado pelo cliente. Este plano de controle de qualidade possui informações confidenciais e, por isto, as análises que ele contém não podem ser detalhadas.

A relação das amostras, suas nomenclaturas e os ensaios a que cada uma foi submetida estão listados na tabela 9. 
Tabela 9 - Nomenclatura das amostras e análises a que foram submetidas.

\begin{tabular}{|c|c|c|c|c|c|}
\hline $\begin{array}{l}\text { Nome da } \\
\text { amostra }\end{array}$ & Triboteste & Interometria ótica & $\begin{array}{c}\text { Microscopia eletrônica de } \\
\text { varredura }\end{array}$ & $\begin{array}{l}\text { Espectroscopia } \\
\text { Raman }\end{array}$ & Dureza Vickers \\
\hline $\begin{array}{l}\text { Cs2 } \\
\text { Cs3 } \\
\text { Vs1 } \\
\text { Vs2 } \\
\text { Vs3 }\end{array}$ & $\begin{array}{c}\text { Ensaios com a } \\
\text { amostra } \\
\text { totalmente } \\
\text { submersa em óleo }\end{array}$ & $\begin{array}{c}\text { Morfologia da superficie antes e } \\
\text { depois dos tribotestes } \\
\text { Parâmetros de Greenwood e } \\
\text { Williamson antes e depois dos } \\
\text { ensaios } \\
\text { Avalição de desgaste }\end{array}$ & $\begin{array}{c}\text { Avaliação da morfologia da } \\
\text { superficie antes e depois dos } \\
\text { ensaios }\end{array}$ & $\begin{array}{l}\text { Análise da } \\
\text { superficie antes e } \\
\text { depois dos } \\
\text { tribotestes (dentro e } \\
\text { fora da trilha) }\end{array}$ & $\begin{array}{c}\text { Dureza superficial dentro da } \\
\text { trilha de desgaste após o } \\
\text { triboteste }\end{array}$ \\
\hline $\begin{array}{l}\mathrm{Cg} 2 \\
\mathrm{Vg} 1 \\
\mathrm{Vg} 2\end{array}$ & $\begin{array}{c}\text { Ensaios com } \\
\text { apenas uma gota } \\
\text { de óleo }\end{array}$ & $\begin{array}{l}\text { Morfologia da superficie antes e } \\
\text { depois dos tribotestes }\end{array}$ & $\begin{array}{c}\text { Avaliação da morfologia da } \\
\text { superficie antes e depois dos } \\
\text { ensaios } \\
\text { Mapa de composição química } \\
\text { (EDS) antes e depois dos } \\
\text { ensaios }\end{array}$ & $\begin{array}{c}\text { Análise da } \\
\text { superficie antes e } \\
\text { depois dos } \\
\text { tribotestes (dentro e } \\
\text { fora da trilha) }\end{array}$ & $\begin{array}{c}\text { Dureza superficial da amostra } \\
\text { antes do triboteste } \\
\text { Dureza superficial dentro da } \\
\text { trilha de desgaste após o } \\
\text { triboteste }\end{array}$ \\
\hline $\begin{array}{l}\mathrm{Ci} 6 \\
\mathrm{Vi5}\end{array}$ & $\begin{array}{l}\text { Ensaios com } \\
\text { apenas uma gota } \\
\text { de óleo e } \\
\text { interrompidos }\end{array}$ & $\begin{array}{l}\text { Morfologia da superficie antes e } \\
\text { depois dos tribotestes }\end{array}$ & $\begin{array}{c}\text { Avaliação da morfologia da } \\
\text { superficie antes e depois dos } \\
\text { ensaios } \\
\text { Mapa de composição química } \\
\text { (EDS) antes e depois dos } \\
\text { ensaios }\end{array}$ & $\begin{array}{c}\text { Análise da } \\
\text { superficie antes e } \\
\text { depois dos } \\
\text { tribotestes (dentro e } \\
\text { fora da trilha) }\end{array}$ & $\begin{array}{c}\text { Dureza superficial da amostra } \\
\text { antes do triboteste } \\
\text { Dureza superficial dentro da } \\
\text { trilha de desgaste após o } \\
\text { triboteste }\end{array}$ \\
\hline
\end{tabular}




\subsubsection{Propriedades mecânicas}

Os resultados dos ensaios usados para determinar as propriedades mecânicas dos blocos utilizados neste trabalho seguem na tabela 10. Esta tabela traz, além das propriedades obtidas através do ensaio de tração, o valor de dureza Brinell de cada amostra do bloco. A amostra (uma por bloco) utilizada no ensaio tração foi retirada do mesmo bloco usado na fabricação das amostras dos tribotestes. A região de extração do corpo de prova de tração e o ensaio de dureza Brinell são executados de acordo com o plano de controle especificado pelo cliente.

Tabela 10 - Propriedades mecânicas obtidas por ensaio de tração dos dois tipos de amostras testados.

\begin{tabular}{lcc}
\hline Propriedades Mecânicas & FC & FV \\
Módulo de elasticidade (GPa) & 134 & 162 \\
Coeficiente de Poisson & 0,26 & 0,26 \\
Tensão de escoamento (MPa) & - & 355 \\
Tensão de ruptura (MPa) & 289 & 531 \\
Dureza (HB) & 229 & 255
\end{tabular}

Os valores obtidos através do ensaio de tração colocam o FC usado neste trabalho na classe 40 de acordo com a ASTM A 48 e o FV na classe 500 de acordo com a ISO 16112.

\subsubsection{Microestrutura}

Para a avaliação da microestrutura das duas ligas testadas neste trabalho foram realizadas análises metalográficas também conforme plano de controle estabelecido pelo cliente da Tupy.

Ferro fundido cinzento: A microestrutura do FC classe 40 usado neste trabalho é constituída de uma matriz totalmente perlítica. As grafitas possuem forma I, tipo A e 
tamanho entre 4 e 6 de acordo com a norma ASTM A 247 [104]. Estes resultados estão expressos na tabela 11.

Tabela 11 - Características da matriz e das grafitas das amostras de FC.

\begin{tabular}{|c|c|c|c|}
\hline \multirow{2}{*}{ Matriz } & \multicolumn{3}{|c|}{ Grafita } \\
\cline { 2 - 4 } & Forma & Tipo & Tamanho \\
\hline $100 \%$ Perlítica & I & A & de 4 a 6 \\
\hline
\end{tabular}

A figura 33 mostra a microestrutura das amostras de FC.

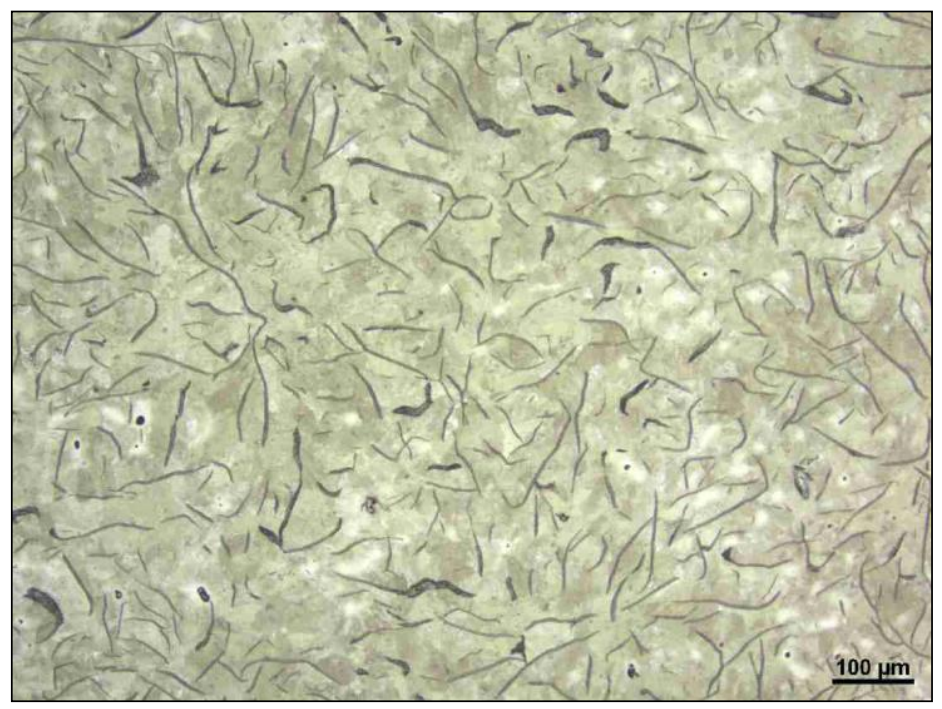

Figura 33 - Microestrutura das amostras de FC. Ataque realizado com nital 3\%.

Ferro fundido vermicular: A microestrutura das amostras de FV classe 500 é constituída de uma matriz com aproximadamente $2 \%$ de ferrita e $98 \%$ de perlita. As grafitas possuem formas I, III e IV de acordo com a norma ASTM A 247 [104] e nodularidade de 17\%. Estes resultados estão expressos na tabela 12.

Tabela 12 - Características da matriz e das grafitas das amostras de FV.

\begin{tabular}{|c|c|c|}
\hline \multirow{2}{*}{ Matriz } & \multicolumn{2}{|c|}{ Grafita } \\
\cline { 2 - 3 } & Forma & Nodularidade \\
\hline $2 \%$ Ferrita & I-III-IV & $17 \%$ \\
\hline
\end{tabular}


A figura 34 mostra a microestrutura das amostras de FV.

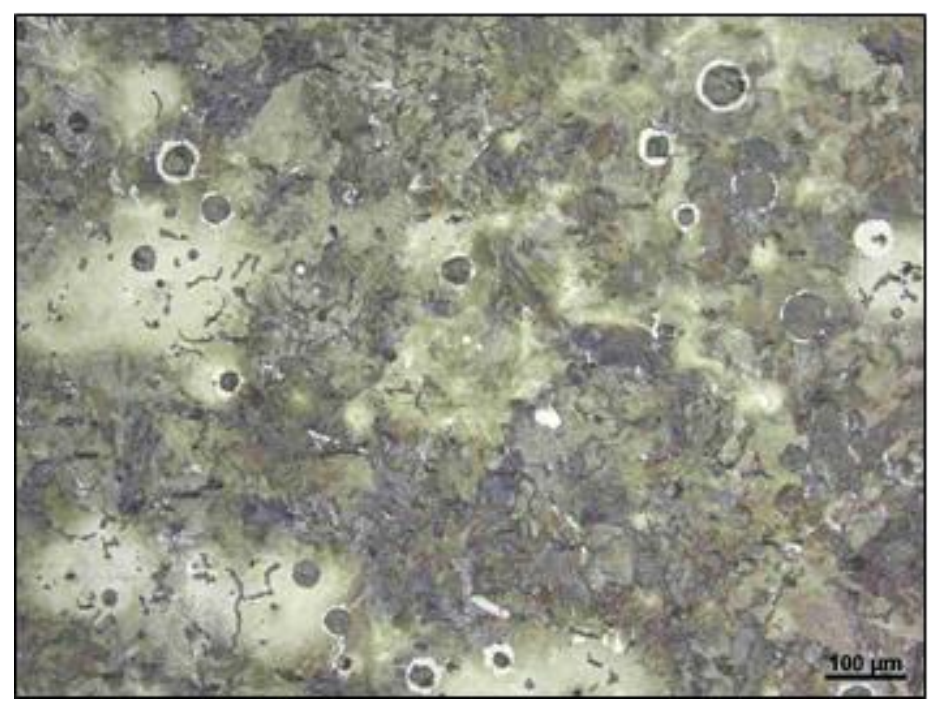

Figura 34 - Microestrutura das amostras de FV. Ataque realizado com nital 3\%.

\subsubsection{Anéis}

O anel utilizado neste trabalho é aplicado em motores diesel, possui $83 \mathrm{~mm}$ de diâmetro e $1 \mathrm{~mm}$ de espessura. $\mathrm{O}$ anel possui uma camada nitretada com dureza Vickers (HV30) de aproximadamente 700 HV. Seu módulo de elasticidade é de 600 GPa e o coeficiente de Poisson de 0,25 GPa.

\subsection{3 Óleo}

O óleo escolhido é comercial e usado em automóveis de passeio que possuem motores flex. Trata-se de um óleo totalmente formulado, 5w30 SM. Este óleo foi escolhido com base nos resultados obtidos por Acero [26] que constatou a ativação do MoDTC. Como é extremamente difícil ter acesso à formulação do óleo, o conhecimento prévio da presença de um aditivo como o MoDTC, que tem forte influência no coeficiente de atrito, é importante para avaliação do desempenho triboquímico dos materiais que estão em estudo. 


\subsection{Métodos}

\subsubsection{Microdureza Vickers}

As medições microdureza Vickers (HV) foram realizadas conforme a norma ASTM E384 [105] com o microdurômetro Buehler MMT-3 do LFS (PME-Poli/USP). Para as medições de microdureza da matriz foram usadas duas amostras, uma de FC e uma de FV. Foram realizadas 15 medições para cada microconstituinte (ferrita e perlita) de cada material, utilizando a carga de $10 \mathrm{gf}$. As medições de microdureza da superfície, tanto da trilha de desgaste quanto da superfície brunida foram efetuadas com carga de 100 gf e com 5 repetições para cada amostra testada.

\subsubsection{Espectroscopia Raman}

As análises de espectroscopia Raman foram realizadas utilizando um equipamento Horiba XploRA. As amostras foram submetidas a esta técnica antes e depois dos ensaios em tribômetro. As análises antes dos ensaios tinham como objetivo detectar a presença de grafita e de óxidos na superfície. Enquanto as análises depois dos tribotestes objetivavam caracterizar o tribofilme formado.

Além disto, foram registrados espectros de grafitas nodulares, vermiculares e lamelares para avaliar se havia diferença entre elas na relação $\mathrm{I}_{\mathrm{D}} / \mathrm{I}_{\mathrm{G}}$ (proporção entre a intensidade da banda $D$ em relação a banda $G$ ), porque isto pode afetar a lubricidade da grafita.

O comprimento de onda utilizado foi de $532 \mathrm{~nm}$ em uma faixa espectral de $100 \mathrm{~cm}^{-1}$ a $3600 \mathrm{~cm}^{-1}$. O tempo de aquisição de $10 \mathrm{~s}$ com 10 acumulações mostrou boa razão sinal/ruído e com este tempo de exposição ao laser o tribofilme não foi alterado. $\mathrm{Na}$ grade de difração utilizou-se 2400 linhas/mm com aberturas fenda de emissão (slit) de $200 \mu \mathrm{m}$ e de captação (hole) de $500 \mu \mathrm{m}$. Um filtro óptico de densidade neutra foi utilizado para limitar a potência do laser em 10\% do máximo disponível. Operando com esta limitação de potência do laser não foram detectados sinais de alteração do tribofilme. Os parâmetros de análise de espectroscopia foram determinados tomando como base o trabalho de Acero [26]. 


\subsubsection{Microscopia eletrônica de varredura}

O Microscópio eletrônico de varredura (MEV) utilizado neste trabalho foi um JEOL JSM - 6010LA. Este microscópio possui um detector que possibilita análises de espectroscopia por dispersão de energia de raios $X$ (EDS).

Este equipamento foi usado para registrar imagens da superfície das amostras antes e depois dos tribotestes para mostrar as alterações morfológicas promovidas pelos processos triboquímico.

Além disto, foram feitos mapas de EDS das superfícies das amostras antes dos ensaios, para mostrar a sua composição química inicial, e depois, para evidenciar a presença de elementos formadores de tribofilmes provenientes dos aditivos do óleo. O tempo total de aquisição para cada mapa foi de aproximadamente $34 \mathrm{~min}$, com 50 varreduras ("sweep time") e tempo de permanência ("dwell time") de 0,2 ms. A resolução dos mapas foi de 512 por 384 pixels. O tempo de análise do raio x ("dead time") foi de 24\%, com abertura ("spot size") de 60 e voltagem de $10 \mathrm{kV}$.

O EDS é uma análise semiquantitativa. Por isto, as quantidades de cada elemento não devem ser consideradas como absolutas, mas possibilitam a comparação entre as amostras. Os parâmetros de EDS foram escolhidos tomando como referência o tranalho de Tertuliano [106].

\subsubsection{Perfilometria ótica}

A caracterização topográfica das amostras foi feita com um interferômetro Noncontact Surface Profiler System - Talysurf CCl de fabricação Taylor Hobson. Todas as medições foram feitas com aumento de 10x. Este aumento resulta em uma área medida de $1,71 \times 1,71 \mathrm{~mm}$. As medições de perfilometria ótica foram usadas com duas finalidades. A primeira era a determinação dos seguintes parâmetros:

- Densidade de asperezas ( $\eta$ ), que é calculada computando o número total de asperezas (pontos máximos positivos) localizada acima do plano médio de referência de uma dada topografia.

- Altura média das asperezas $\left(Z_{S}\right)$.

- Raio médio das asperezas ( $\left.\beta_{\mathrm{S}}\right)$. 
Estes parâmetros são conhecidos como parâmetros de Greenwood e Williamson [107], são usados para determinar as características do contato entre as superfícies e foram usados apenas nas análises das amostras que foram submetidas ao ensaio com a amostra totalmente submersa. Nos outros ensaios as alterações topográficas superam o nível das asperezas, reduzindo a relevância dos parâmetros Greenwood e Williamson para as análises. Além disto, estes parâmetros foram controlados nos ensaios com a amostra totalmente submersa porque estes poderiam influenciar na ativação do MoDTC.

Para determinação destes parâmetros foi registrada uma imagem tridimensional do centro da amostra, na mesma região onde ocorreria o contato do anel durante o triboteste. Esta medição foi submetida aos seguintes tratamentos utilizando o programa TalyMap:

- Nivelamento: serve para corrigir virtualmente a perpendicularidade da amostra em relação ao feixe de luz, ou seja, corrige qualquer possível inclinação da amostra.

- Preenchimento dos pontos não medidos: em alguns pontos da superfície medida o equipamento não consegue ajustar o foco adequadamente e por isto ele não registra aquele ponto. A ferramenta de preencher pontos não medidos toma os pontos do entorno do ponto no medido como referência e faz uma "previsão" de onde aquele ponto deveria estar.

- Remoção de forma: No caso das seções de cilindro, que são as amostras deste trabalho, a forma é cilíndrica. A ferramenta reformação de forma exclui esta forma tornando a amostra virtualmente plana.

A figura 35 ilustra os tratamentos da imagem da superfície. 

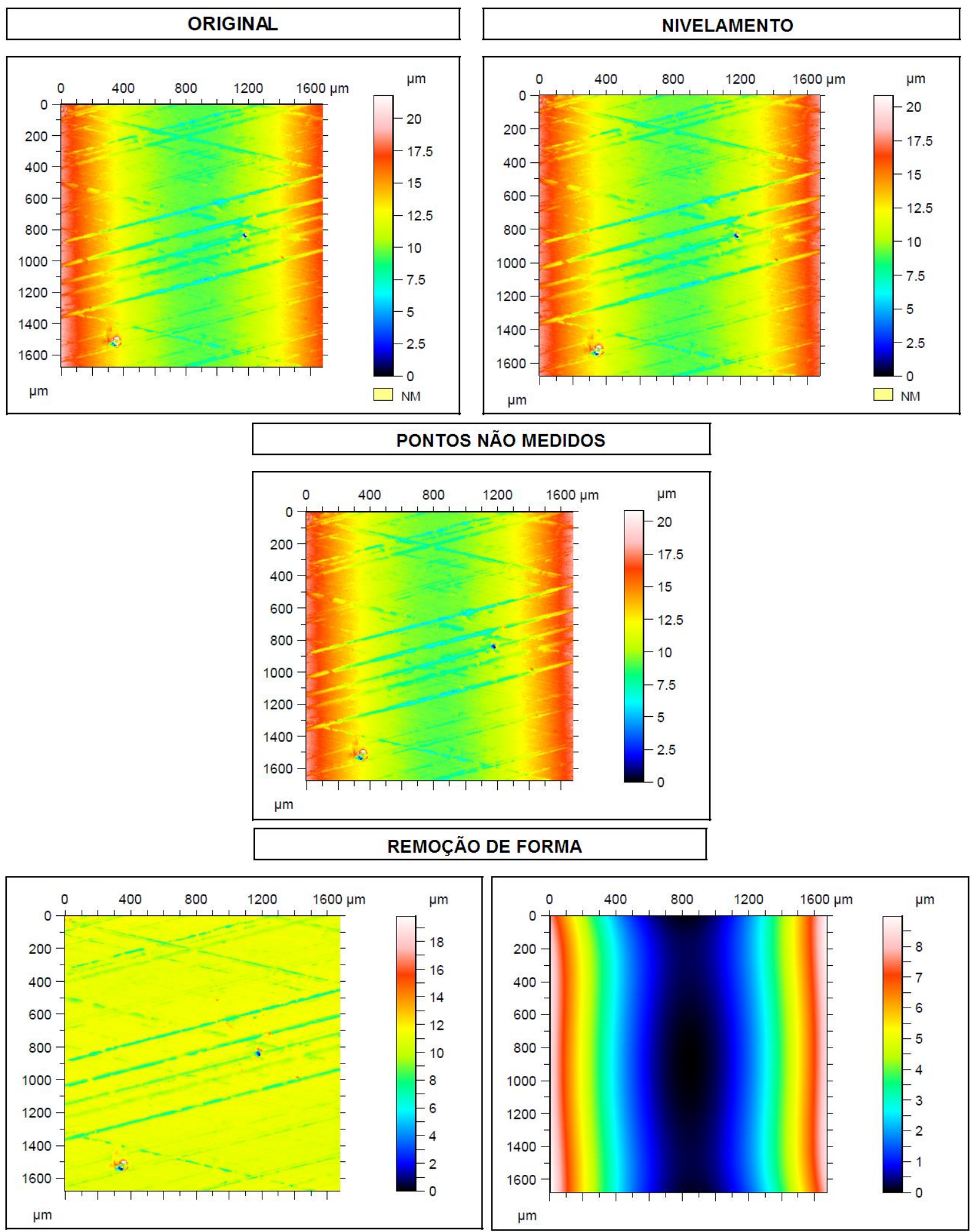

Figura 35 - Tratamentos feitos na imagem antes da retirada dos perfis utilizados para o cálculo dos parâmetros de Greenwood e Williamson.

Depois de tratada a imagem foram retirados 7 perfis bidimensionais equidistantes que foram submetidos ao tratamento do programa MAHLE-SUMMITS, desenvolvido 
pela empresa Mahle e que é capaz de extrair os parâmetros de Greenwood e Williamson de perfis de rugosidade. A figura 36 mostra a interface do Summits.

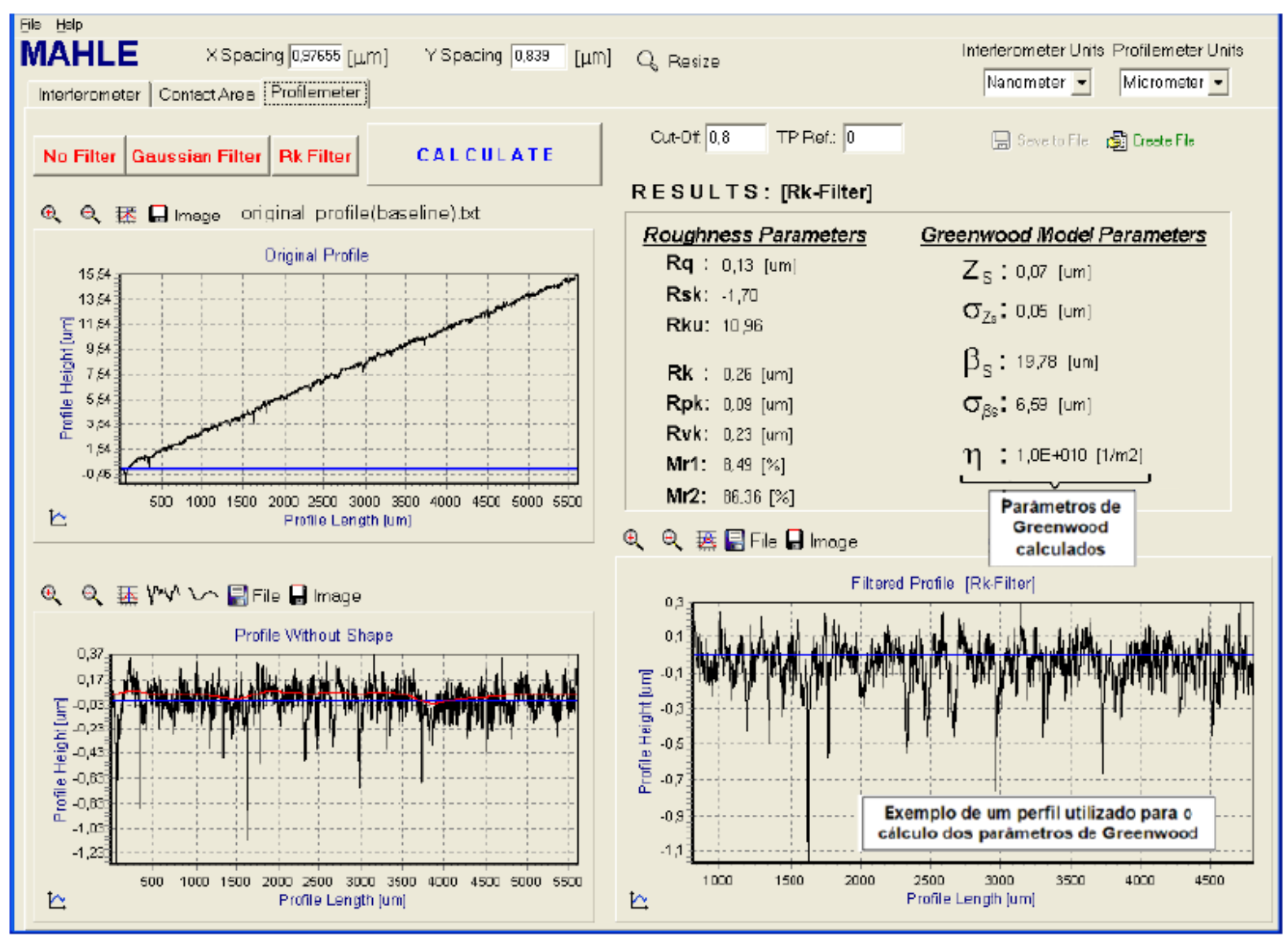

Figura 36 - Interface do programa Summits usado para extrair os parâmetros de Greenwood e Williamson de um perfil de rugosidade [109].

Como foram retirados 7 perfis para cada amostra existem 7 valores de $\eta, Z_{S}$ e $\beta_{S}$ para cada uma delas. Com estes 7 valores foi tirada a média. Deste modo, cada valor de $\eta, Z_{S}$ e $\beta_{S}$ é uma média de 7 valores obtidos para cada amostras.

A técnica de perfilometria ótica também utilizada para medir o desgaste das amostras após os tribotestes. Nestes casos foi realizado um conjunto de 11 medições de 3 por 1 . Isto significa que cada medição é uma montagem de 3 medidas de $1,71 \times 1,71 \mathrm{~mm}$ realizadas transversalmente à trilha de desgaste. Já as 11 medições foram feitas no mesmo sentido da trilha de desgaste para que fosse possível fazer uma montagem de toda a trilha de desgaste e para que a medição refletisse o desgaste total da amostra. Isto é necessário porque, mesmo utilizando um sistema para alinhar o anel sobre a amostra de cilindro, é difícil garantir que o 
contato será uniforme ao longo de toda a interface. A figura 37 ilustra uma medição feita em uma trilha de desgaste e a reconstrução da trilha a partir das 11 medições realizadas ao longo da trilha.

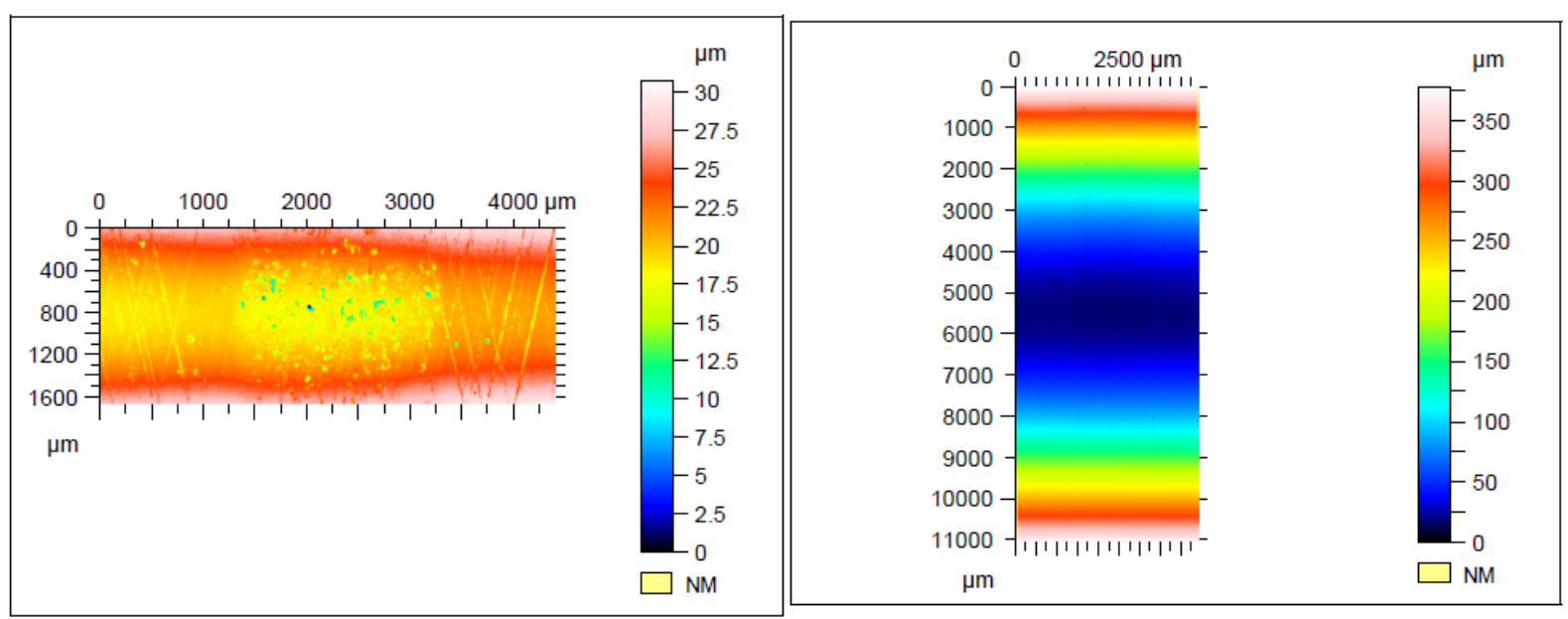

Figura 37 - À esquerda uma imagem de uma parte da trilha de desgaste feita com 3 medições no sentido transversal ao risco por uma medição no sentido do risco e à direita uma montagem com 11 medições 3 por 1 reconstruindo completamente a trilha de desgaste.

Com o risco reconstruído foram registrados 1355 perfis da superfície e extraído deles um perfil médio. O desgaste foi então determinado como área da trilha de desgaste do perfil médio. É importante salientar que com esta metodologia não é calculado o desgaste absoluto da amostra. O que se tem é uma medida de desgaste representativa de toda amostras e que pode ser usada para comparar o desgaste entre os dois materiais em estudo. A figura 38 ilustra uma medição de desgaste realizada usando esta técnica. 

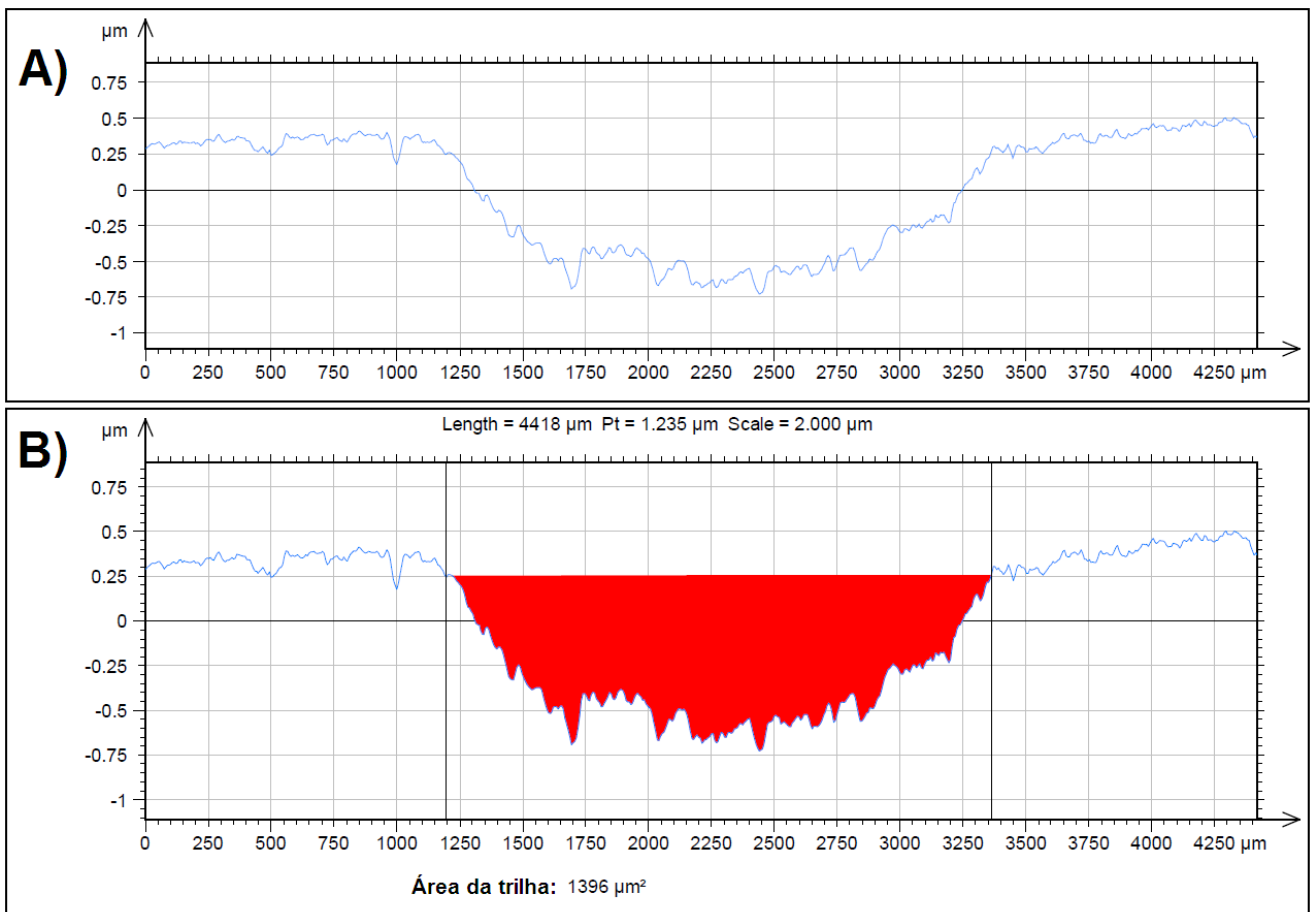

Figura 38 - Perfil médio de uma trilha de desgaste $(A)$ e área da trilha de desgaste medida através do perfil médio (B).

\subsubsection{Triboteste}

Os tribotestes foram realizados na máquina SRV-4, fabricada pela Optimol e que está instalada no Laboratório de Fenômenos de Superfície (LFS). Este equipamento produz um movimento alternado do anel contra uma seção do cilindro que simula parte do movimento que acontece em um de motor de combustão interna real. A figura 39 mostra a configuração do teste de anel contra cilindro executado na SRV-4.

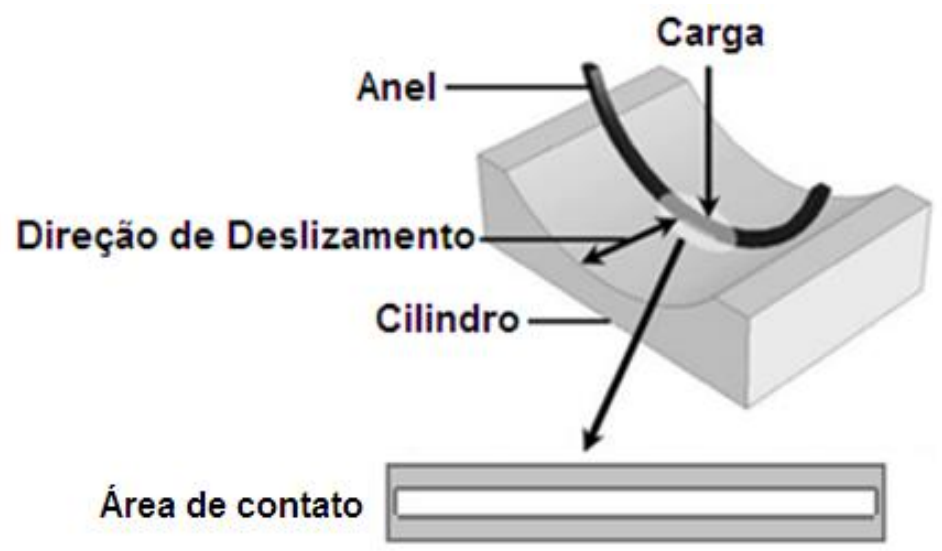

Figura 39 - Configuração do teste de anel contra cilindro executado na SRV-4, mostrando a aplicação da carga, direção do deslizamento e área de contato conforme que esta configuração gera. 
A SRV-4 permite controlar parâmetros como carga axial, temperatura, frequência e amplitude de oscilação. A carga pode ir até $2000 \mathrm{~N}$, a temperatura até $900{ }^{\circ} \mathrm{C}$, a frequência até $500 \mathrm{~Hz}$ aproximadamente e a amplitude de oscilação até $5 \mathrm{~mm}$. A limitação na amplitude de oscilação, muito menor que a amplitude de oscilação de um sistema real, não permite que o movimento do anel sobre o cilindro seja totalmente replicado pelo equipamento. Por isto, e levando em consideração que o ponto morto superior é a região que é exposta as condições de operação mais severas, o triboteste foi desenvolvido para simular esta região.

Além de simular o ponto morto superior, os tribotestes foram desenvolvidos para avaliar o comportamento dos aditivos do óleo na formação do tribofilme e sua influência no desempenho do tribossistema. Para tanto, foram testadas duas condições de lubrificação: ensaios com as amostras totalmente submersas em óleo e ensaios utilizando apenas uma gota de óleo. No primeiro a duração dos ensaios foi de 6 horas, enquanto no segundo foi de 1 hora. $O$ ensaio utilizando apenas uma gota de óleo também foi repetido sendo interrompido após 5 e 6 minutos do seu início. Estes ensaios foram chamados de ensaios utilizando apenas uma gota de óleo e interrompidos. A figura 40 ilustra as duas condições de fornecimento de óleo usadas neste trabalho.

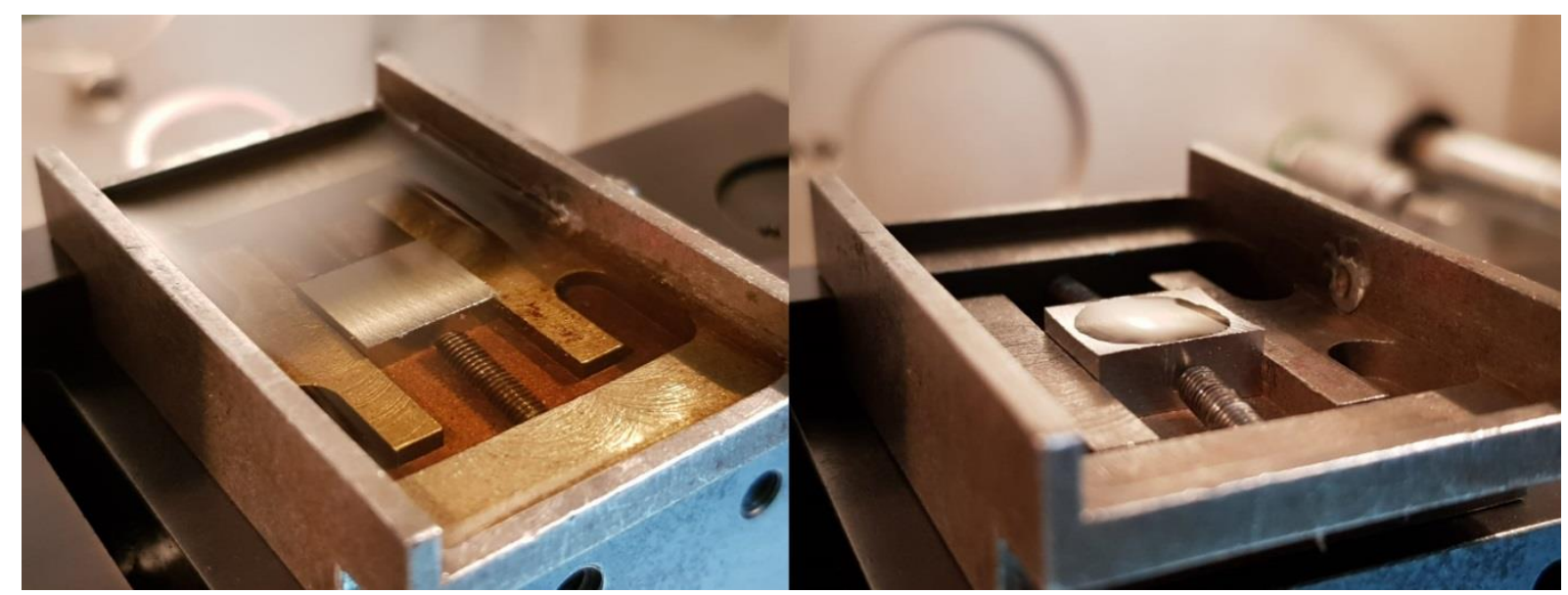

Figura 40 - Amostra submersa em óleo à esquerda e amostra com apenas uma gota de nas uma gota de óleo à direita.

A tabela 13 mostra os parâmetros de ensaio escolhidos para o triboteste e que foram comuns aos 3 tipos de ensaios. 
Tabela 13 - Parâmetros de ensaio do triboteste

Parâmetros de ensaio

\begin{tabular}{lr}
\hline Carga $(\mathrm{N})$ & 160 \\
Frequência $(\mathrm{Hz})$ & 50 \\
Temperatura $\left({ }^{\circ} \mathrm{C}\right)$ & 120 \\
Amplitude $(\mathrm{mm})$ & 2 \\
Comprimento do contato $(\mathrm{mm})$ & 10 \\
Largurado contato $(\mathrm{mm})$ & 1
\end{tabular}

É importante salientar que nos ensaios deste trabalho as condições de fornecimento de óleo para o tribossistema não simulam as condições usuais de operação de um motor de combustão interna. O ensaio com a amostra submersa em óleo foi desenvolvido para aumentar o potencial das reações triboquímicas por oferecer abundância de aditivos ao tribossistema. Os ensaios executados com apenas uma gota de óleo foram pensados para oferecer uma condição de starvation, que é uma quantidade tão pequena de óleo que torna a lubrificação incipiente e leva o tribossistema ao limite. Esta condição é induzida para avaliar a resistência do tribossistema ao scuffing.

Os dados de coeficiente de atrito fornecidos pela máquina foram tratados segundo o que Tertuliano [106] denominou de coeficiente de atrito "pico a pico" e trata-se do gráfico gerado pela máquina em tempo real durante o ensaio e fornecido automaticamente. Cada ponto do gráfico de coeficiente de atrito pico a pico é uma média aritmética dos valores de coeficiente de atrito registrados nos pontos de reversão do curso durante o período de 1 segundo. 


\section{RESULTADOS}

A apresentação dos resultados está organizada com o foco nos tribotestes. Por isto, terá início com as caracterizações preliminares, no ítem 4.1. Esta seção traz informações relevantes sobre as características dos tipos de ferros fundidos testados. Porém, estas amostras não foram submetidas aos tribotestes. Em seguida, as seções 4.2 (ensaios com a amostra submersa em óleo), 4.3 (ensaios utilizando apenas uma gota de óleo) e 4.4 (ensaios utilizando apenas uma gota de óleo e interrompidos) tratam dos resultados das amostras que foram submetidas a cada tipo de triboteste proposto por este trabalho.

\subsection{Caracterizações preliminares}

As caracterizações preliminares foram executadas para determinar características dos dois tipos de ferros fundidos utilizados neste trabalho quem podem ter influência no desempenho do tribossistema. Estas caracterizações foram realizadas em amostras retiradas do mesmo bloco de onde foram extraídas as amostras usadas nos tribotestes. Porém, as amostras destas caracterizações não foram submetidas aos tribotestes e, por isto, não recebem o mesmo padrão de denominação apresentado no item 3.1.1.

\subsubsection{Microdureza Vickers}

A tabela 14 traz os valores de microdureza dos microconstituintes das matrizes dos materiais em estudo neste trabalho. 
Tabela 14 - Microdureza dos microconstituintes das matrizes do FV e do FC.

\begin{tabular}{ccccc} 
& & \multicolumn{2}{c}{ FV } & FC \\
& Perlita & Ferrita & Perlita \\
\cline { 2 - 5 } Dureza HV 0,01 & Média & 327 & 212 & 338 \\
& Desvio & 28 & 15 & 29
\end{tabular}

Como era esperado a perlita dos dois materiais possuem durezas muito próximas e a ferrita do FV promove uma redução da dureza da matriz. Porém, como o FV possui apenas $2 \%$ de ferrita na matriz a redução de dureza esperada é muito pequena, sendo menos de $1 \mathrm{HV}$.

A diferença de dureza entre as perlitas do FV e do FC não pode ser considerada significativa porque seus desvios se sobrepõem. Isto pode ser observado através do gráfico da figura 41.

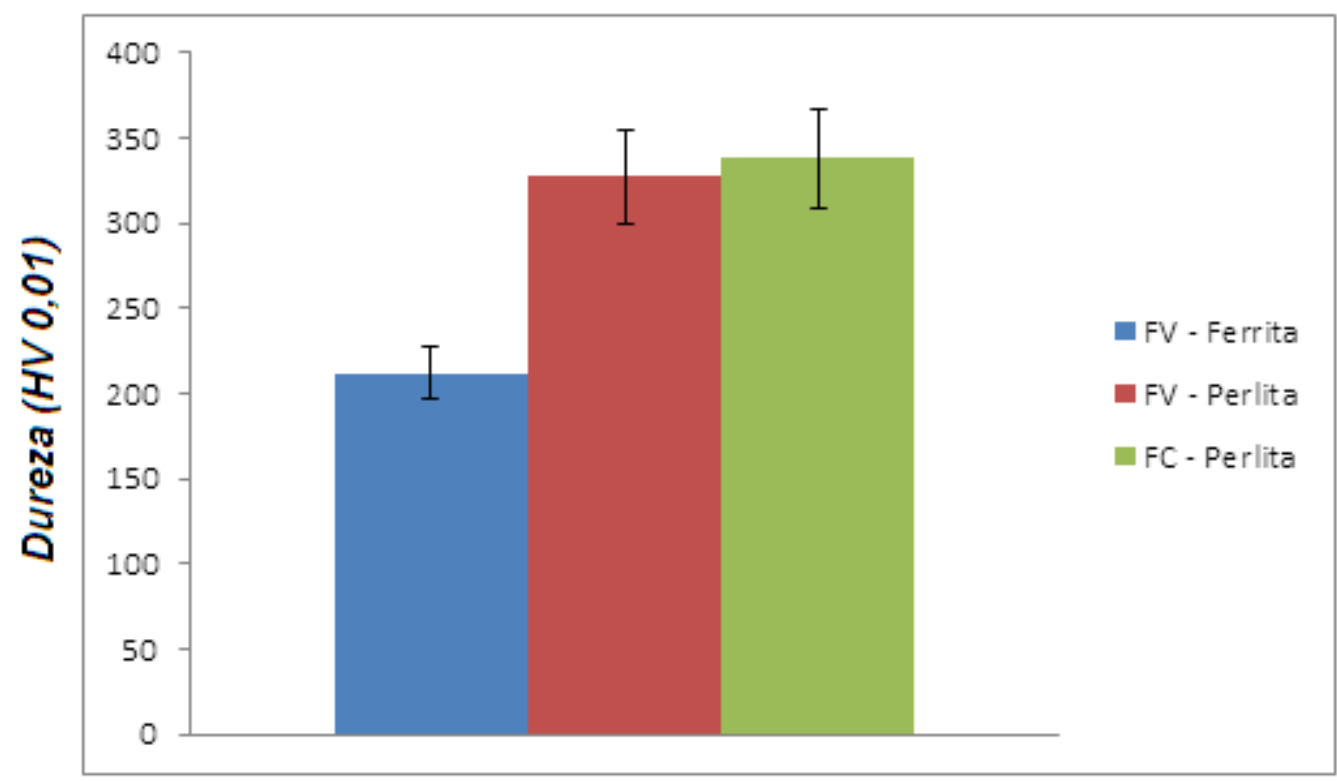

Figura 41 - Microdureza (HV 0,01) dos microsconstituintes das matrizes do FV e FV.

\subsubsection{Espectroscopia Raman}

O gráfico da figura 42 mostra os espectros registrados para uma grafita nodular, uma vermicular e uma lamelar. Neste gráfico é possível notar que não há diferença significativa entre os espectros de cada tipo de grafita. Isto significa que não é 
esperada diferença de capacidade de lubrificação sólida pela grafita devido a sua forma.

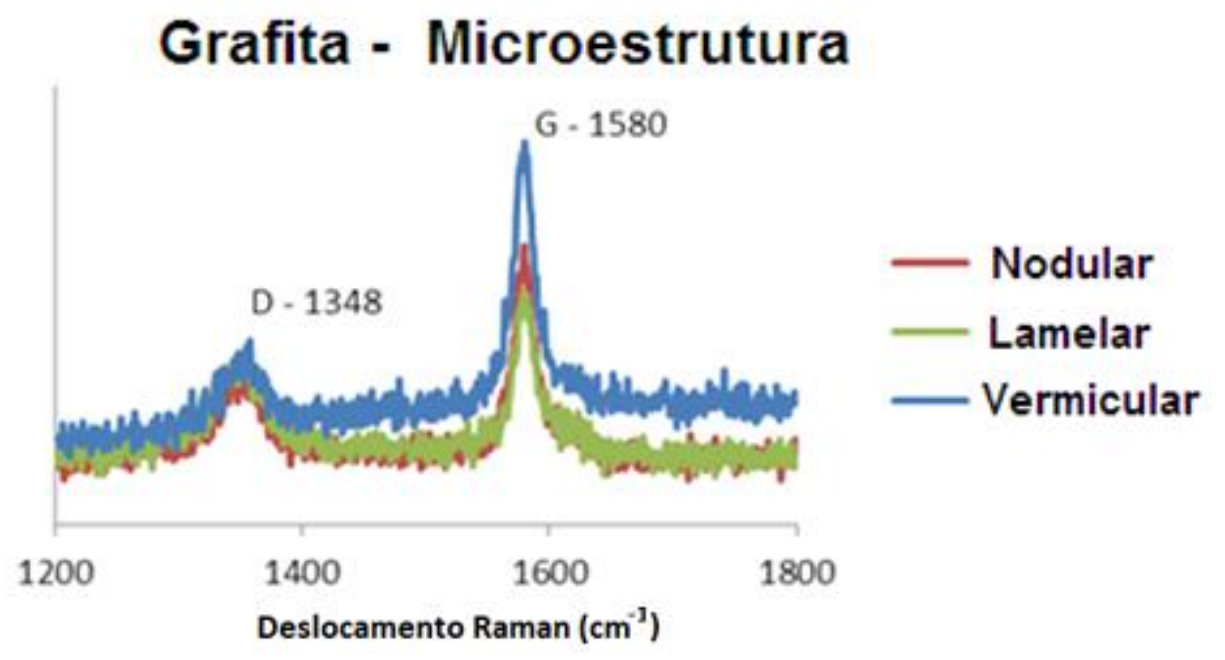

Figura 42 - Espectros Raman de uma grafita nodular, uma lamelar e uma vermicular.

\subsection{Ensaios com a amostra submersa em óleo}

\subsubsection{Microdureza Vickers}

A tabela 15 traz os valores das medições de microdureza da superfície das amostras fora da trilha de desgaste, dentro dela e o ganho percentual de dureza devido ao encruamento da superfície devido ao processo de desgaste. As medições identificadas como superfície são de fora da trilha de desgaste enquanto as identificadas como trilha são de dentro da trilha de desgaste. Os dados desta tabela mostram que as amostras possuem diferenças de dureza entre si, tanto nos valores relativos às medições fora da trilha de desgaste quanto às de dentro da trilha de desgaste. Porém, não há uma diferença significativa de dureza que possa ser atribuída ao tipo de ferro fundido. Isto é confirmado pelos gráficos das figuras $43 \mathrm{e}$ 44. 
Tabela 15 - Microdureza da superfície e da trilha de desgaste das amostras de FC e FV usadas nos ensaios com a amostra submersa em óleo.

Dureza Vickers HV 0,1

\begin{tabular}{|c|c|c|c|c|}
\hline & & Média & Desvio & Aumento da dureza (\%) \\
\hline \multirow{2}{*}{ FC-1 } & superficie & 528 & 25 & \multirow{2}{*}{15} \\
\hline & trilha & 606 & 53 & \\
\hline \multirow{2}{*}{ FC-2 } & superficie & 481 & 53 & \multirow{2}{*}{3} \\
\hline & trilha & 494 & 15 & \\
\hline \multirow{2}{*}{ FC-4 } & superficie & 430 & 37 & \multirow{2}{*}{12} \\
\hline & trilha & 483 & 19 & \\
\hline \multirow{2}{*}{ FV-1 } & superficie & 462 & 15 & \multirow{2}{*}{20} \\
\hline & trilha & 556 & 20 & \\
\hline \multirow{2}{*}{ FV-3 } & superficie & 391 & 43 & \multirow{2}{*}{17} \\
\hline & trilha & 456 & 29 & \\
\hline \multirow{2}{*}{ FV-4 } & superficie & 471 & 26 & \multirow{2}{*}{18} \\
\hline & trilha & 556 & 29 & \\
\hline
\end{tabular}

O gráfico da figura 43 , relativo às medições de dureza superficial antes do triboteste (superfície), mostra que as amostras podem ser consideradas estatisticamente iguais em relação a sua dureza superficial. As duas exceções são a amostra Vs2 que possui dureza estatisticamente inferior às demais com seu desvio padrão se sobrepondo apenas ao da amostra Cs3 e a amostra Cs1 que pode ser considerada como tendo dureza superficial superior às outras, tendo como única exceção a amostra Cs2 cujo desvio padrão se sobrepõe ao dela.

As diferenças de dureza encontradas de uma amostra para a outra mesmo entre as amostras fabricadas com o mesmo tipo de ferro fundido podem ser atribuídas ao processo de brunimento a que elas foram submetidas. As amostras foram retiradas de várias regiões diferentes dos cilindros que não foram identificadas antes da sua fabricação. Parâmetros de brunimento como velocidade de corte, avanço e rotação da ferramenta variam ao longo do curso da ferramenta dentro do cilindro. Esta variação dos parâmetros pode promover diferentes graus de encruamento da superfície e consequentemente diferentes durezas superficiais resultantes. 


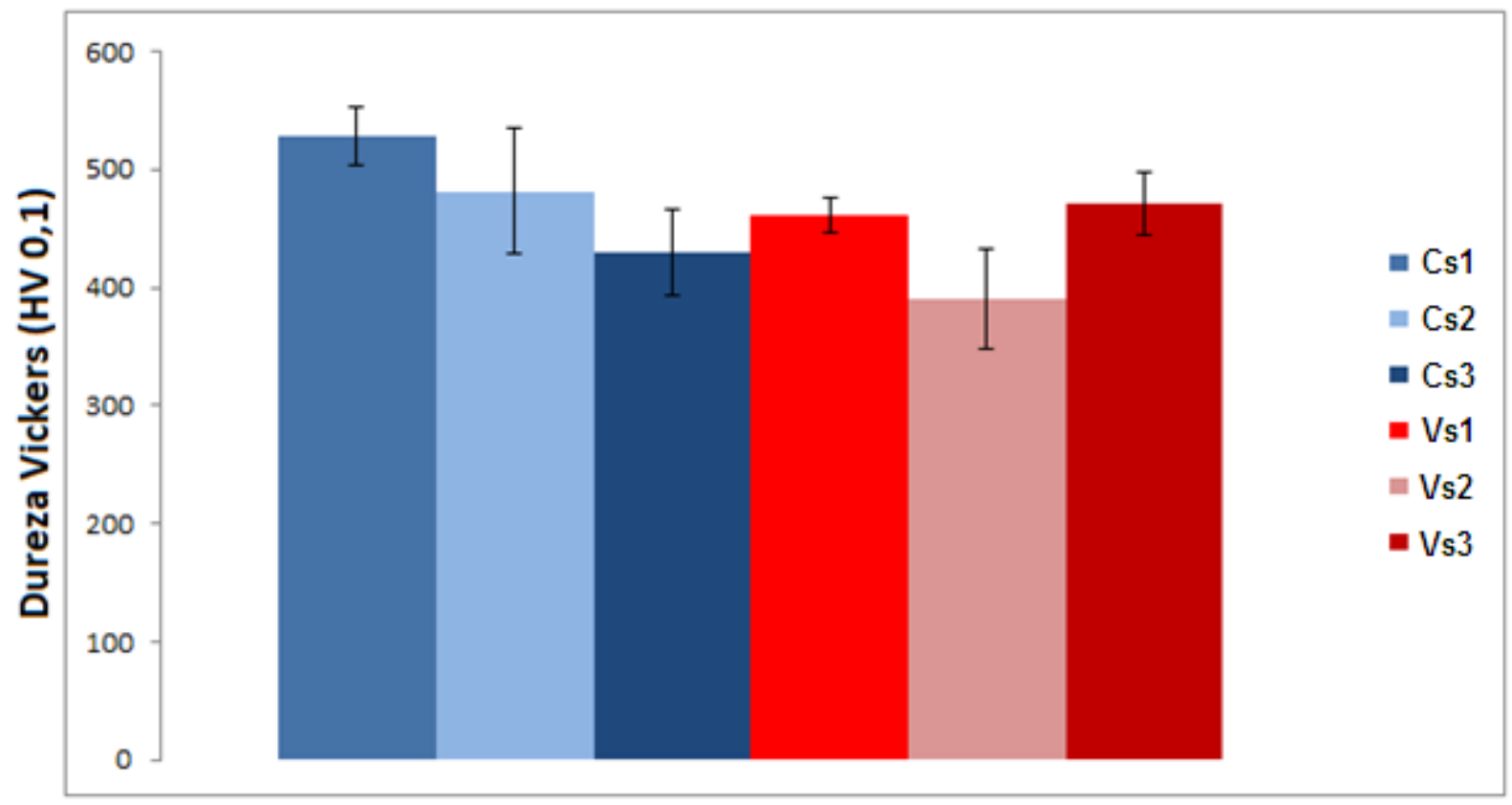

Figura 43 - Dureza da superfície das amostras FC e FV fora da trilha de desgaste

O gráfico da figura 44 traz as medições de dureza dentro da trilha de desgaste e mostra que há dois grupos de dureza encontrados. As amostras podem ser consideradas iguais em dureza dentro do grupo, mas os dois grupos possuem durezas estatisticamente diferentes. O grupo de menor dureza contém as amostras Cs2, Cs4 e Vs2. Já o grupo de maior dureza possui as amostras Cs1, Vs1 e Vs4.

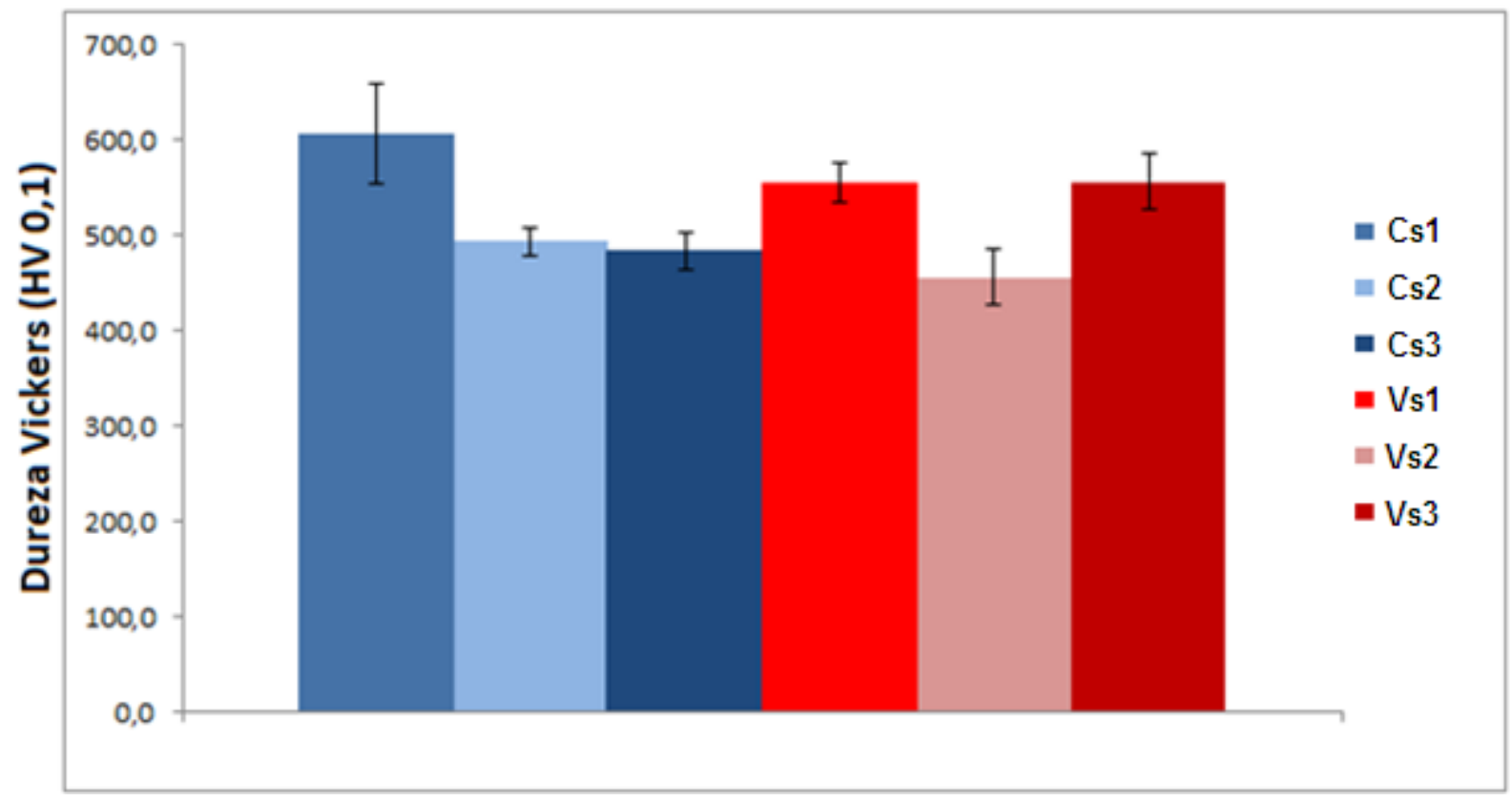

Figura 44 - Dureza da superfície das amostras FC e FV dentro da trilha de desgaste. 


\subsubsection{Espectroscopia Raman}

Quando analisadas as superfícies das amostras antes dos tribotestes é possível encontrar duas regiões com espectros distintos. Estas regiões são as de platô e as de fenda. Estas duas regiões podem ser identificadas através das imagens de MEV da figura 45.

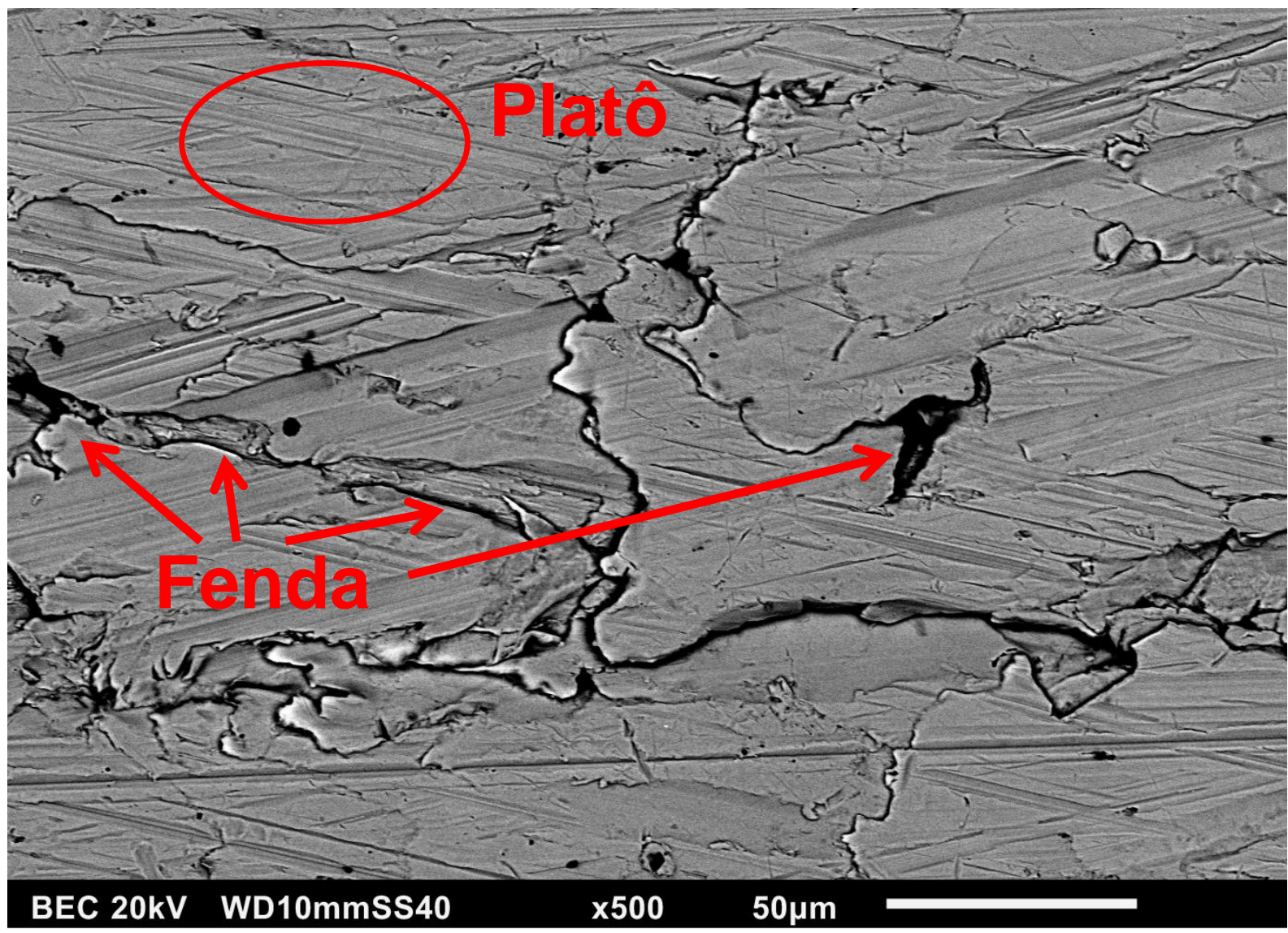

Figura 45 - Imagem de MEV da superfície de uma amostra de FC com a identificação das regiões de fenda e platô.

Os platôs são regiões mais altas da superfície e que possuem rugosidades mais baixas. As fendas são formadas pela deformação da matriz dos ferros fundidos sobre as grafitas que afloram a superfície. A figura 46 mostra uma imagem de MEV da seção transversal de uma amostra de FC evidenciando uma região onde a matriz do material foi deformada sobre as grafitas formando as fendas. 


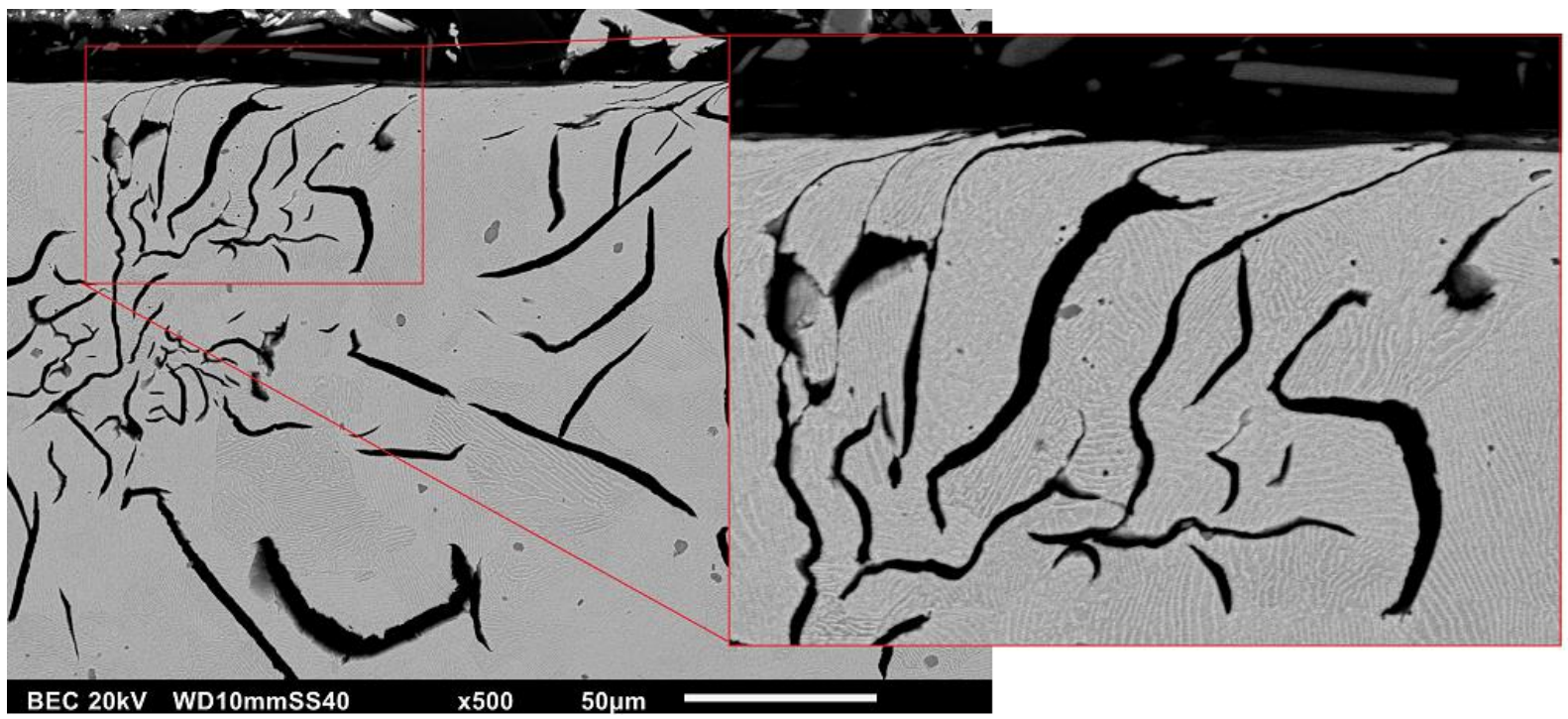

Figura 46 - Deformação da matriz do FC sobre grafitas que afloram a superfície formando as fendas.

Todas as amostras analisadas antes dos tribotestes com amostras submersas em óleo apresentaram as mesmas características: Um espectro característico da grafita nas regiões de fenda e um espectro sem picos definidos nas regiões de platô, o que indica uma superfície metálica com pouca ou nenhuma oxidação. Os espectros de todas as amostras analisadas se encontram na figura 47 (fenda) e 48 (platô).

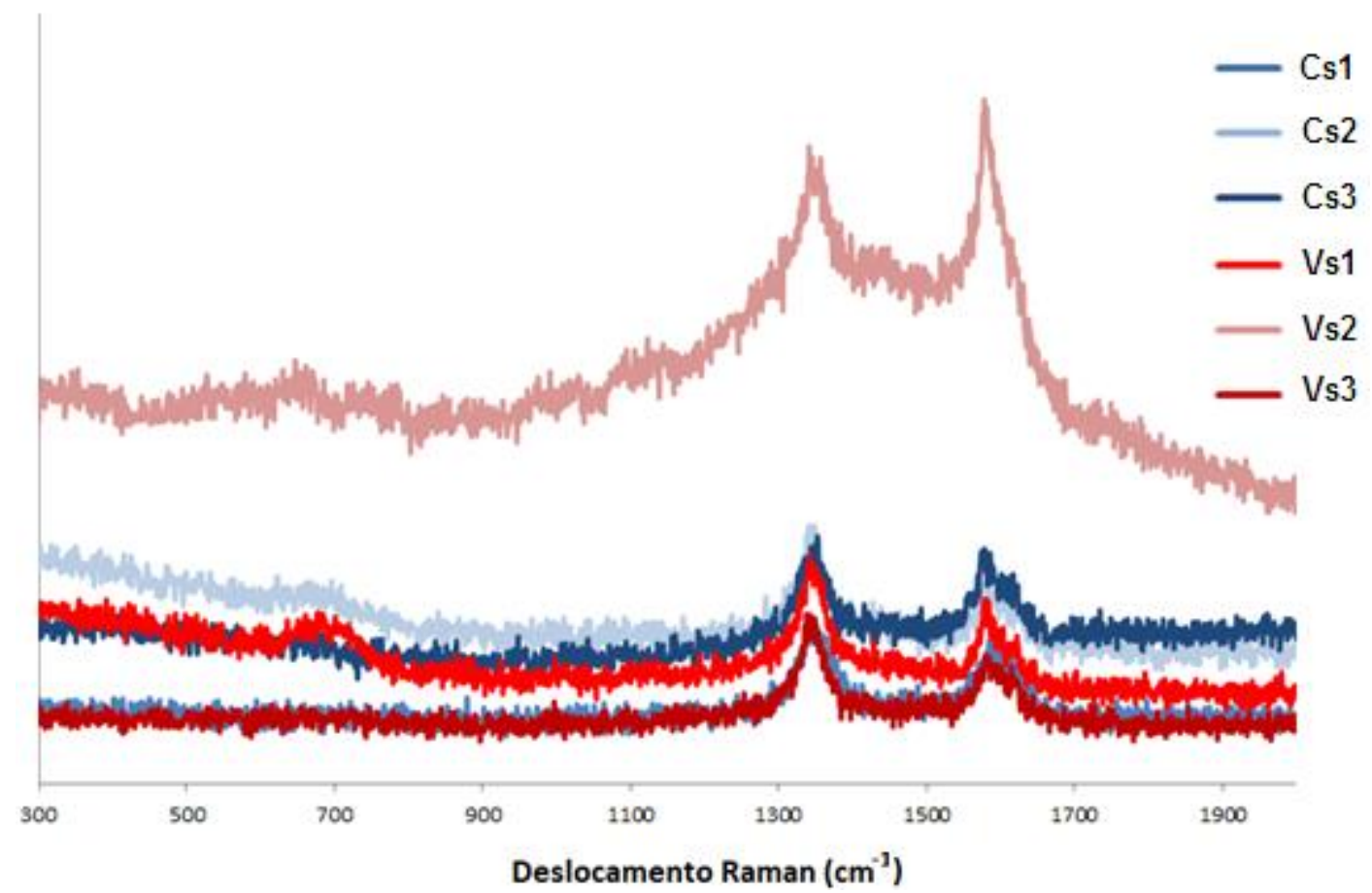

Figura 47 - Espectros Raman registrados nas fendas das amostras de FC (tons de azul) e FV (tons de vermelho). 


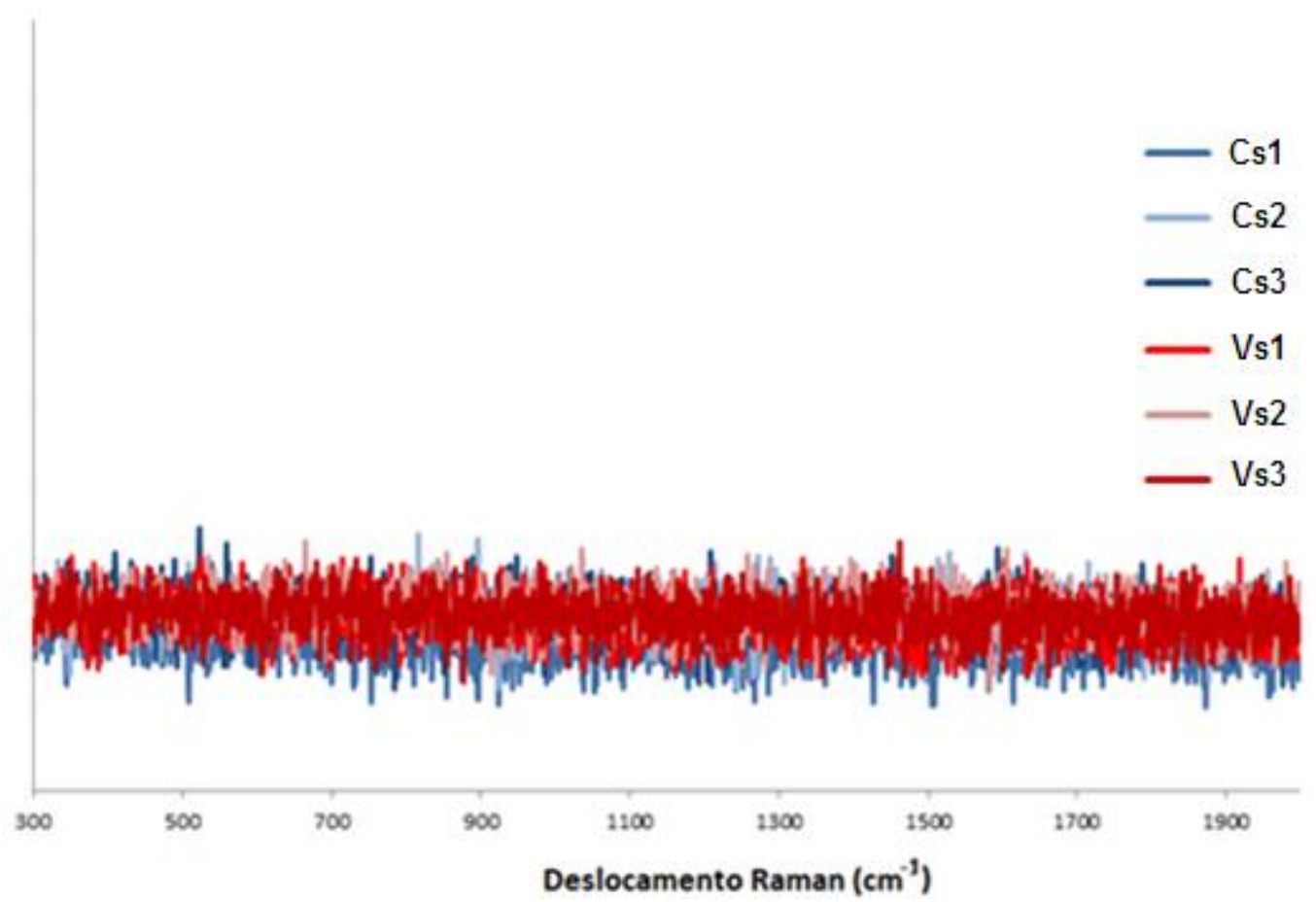

Figura 48 - Espectros Raman registrados nos platôs das amostras de FC (tons de azul) e FV (tons de vermelho).

Os espectros colhidos dentro das trilhas de desgaste também não mostraram diferenças significativas entre as amostras de FV e FC. Todas as amostras apresentaram espectros bem definidos e característicos do $\mathrm{MoS}_{2}$ [63, 67, 70 e 71] por toda a trilha de desgaste. Isto significa que a ativação do MoDTC aconteceu e que o recobrimento da superfície pelo tribofilme de $\mathrm{MoS}_{2}$ ocorreu de maneira eficiente. Também foram feitas medições fora da trilha de desgaste para verificar a formação de filmes térmicos. Este tipo de filme não foi encontrado em nenhuma das amostras. A figura 49 mostra um espectro registrado dentro da trilha de desgaste enquanto os espectros registrados fora estão na figura 50 . Nesta figura é mostrada a região do espectro entre 150 e $800 \mathrm{~cm}^{-1}$, porém as varreduras cobriram de $150 \mathrm{a}$ $3600 \mathrm{~cm}^{-1}$ para que fosse possível a detecção desde óxidos até compostos orgânicos se estes estivessem presentes nas superfícies das amostras. 


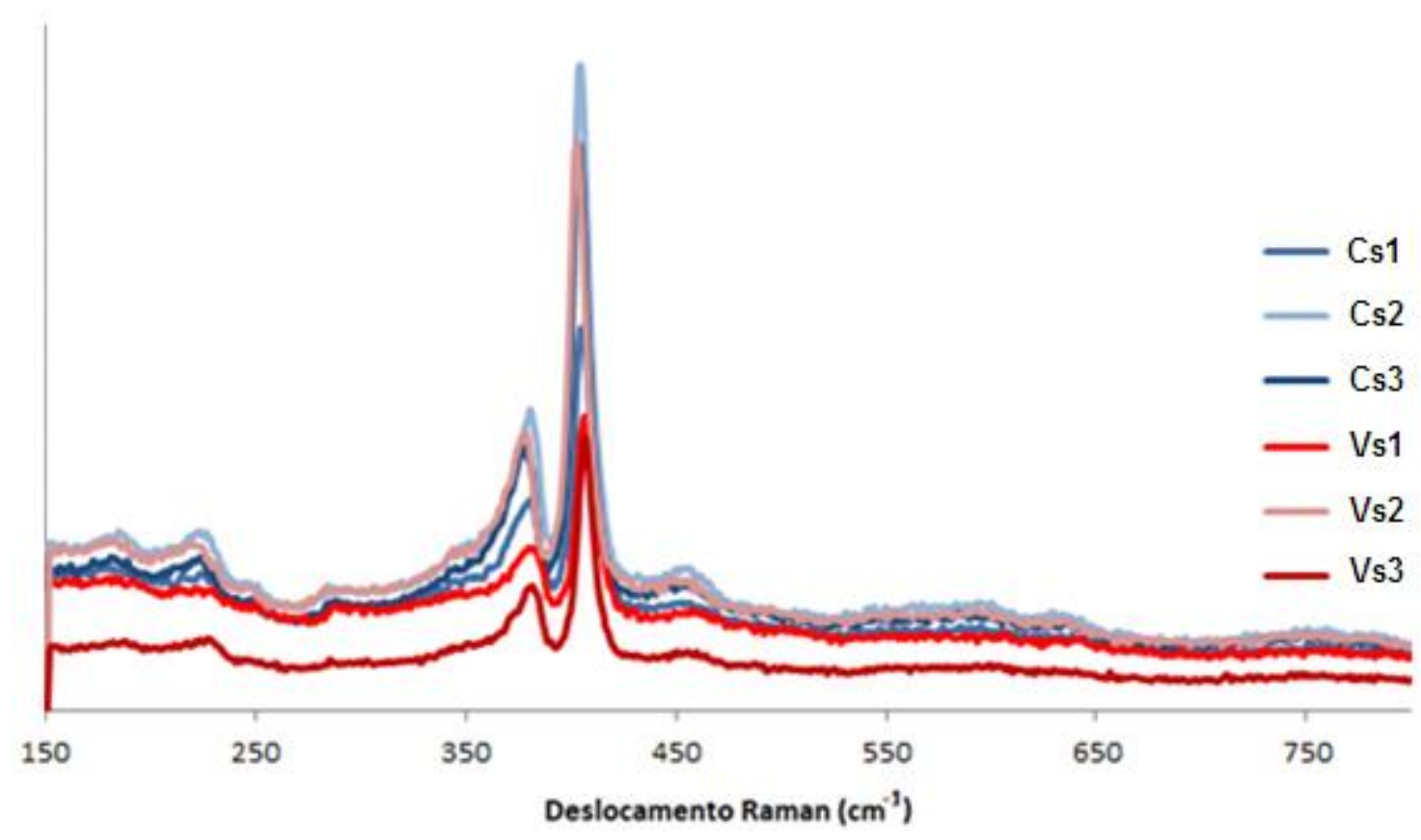

Figura 49 - Espectros registrados dentro da trilha de desgaste da amostra de FC (tons de azul) e FV (tons de vermelho)

Através da análise dos espectros da figura 49 não é possível notar diferença entre as amostras analisadas. Todas apresentaram o mesmo comportamento, com um filme bem estabelecido de $\mathrm{MoS}_{2}$ dentro da trilha. $\mathrm{O}$ gráfico da figura 50 mostra um espectro de cada amostra coletado fora da trilha de desgaste. Em nenhuma das amostras foi detectada formação do filme de $\mathrm{MoS}_{2}$ fora da trilha de desgaste. $\mathrm{O}$ único pico representativo destes espectros se encontra por volta de $2900 \mathrm{~cm}^{-1}$ e está associado a ligações alifáticas entre $\mathrm{C} \mathrm{e} \mathrm{H}$ dos grupos metil, metileno e metino. $\mathrm{A}$ presença de resíduo de óleo que permaneceu na superfície mesmo após a limpeza no ultrassom explicaria a ocorrência deste pico. 


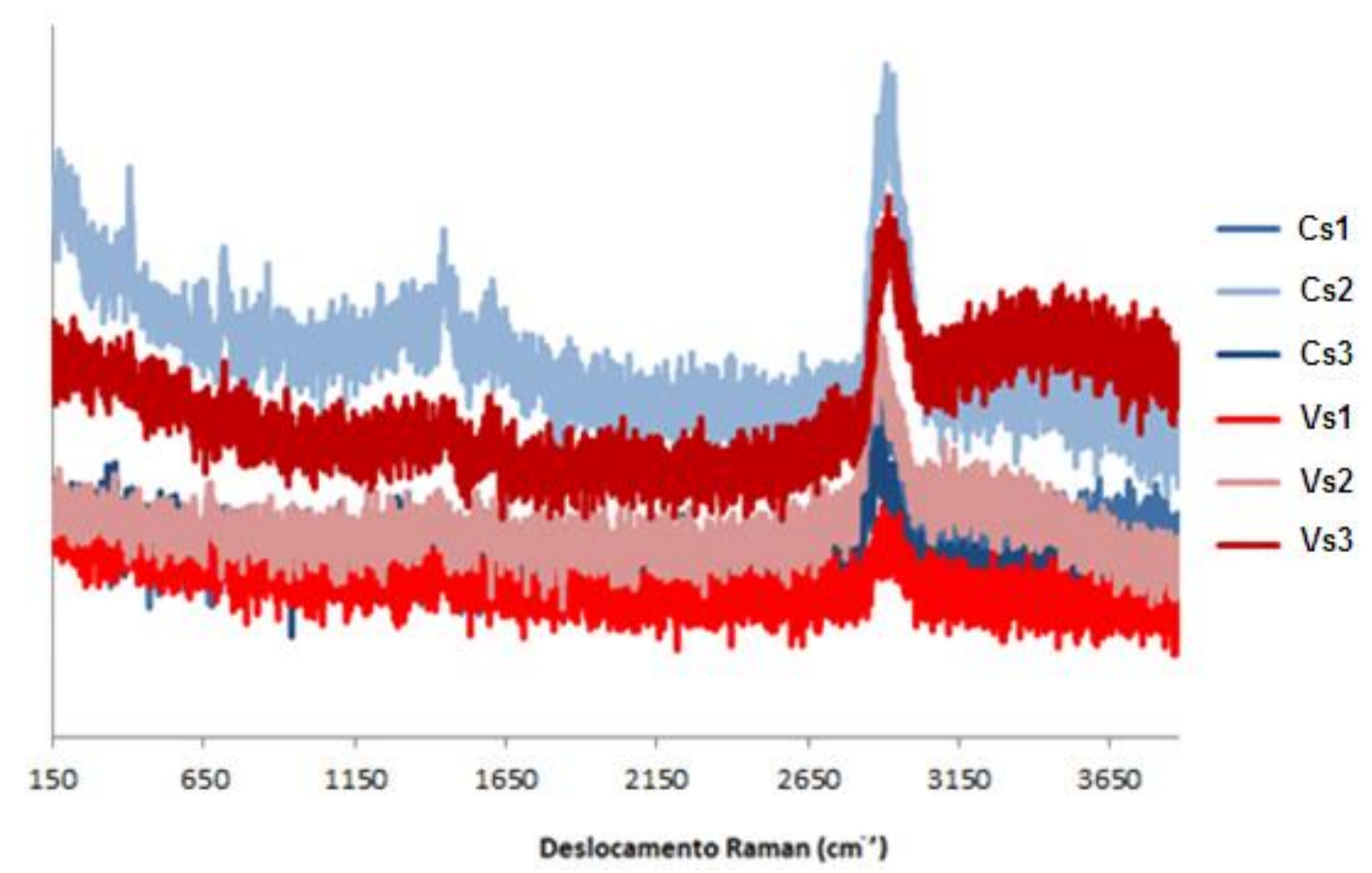

Figura 50 - Espectros registrados fora da trilha de desgaste da amostra de FC (tons de azul) e FV (tons de vermelho)

\subsubsection{Microscopia eletrônica de varredura}

A análise da morfologia da superfície das amostras antes dos ensaios mostra a configuração de uma superfície gerada por brunimento de platô usual. As superfícies, tanto das amostras de FV quanto de FC, apresentam riscos profundos que delimitam os platôs e nos platôs há riscos de profundidade menor. Também há fendas e material dobrado. Do Vale [81] não distingue as fendas do material dobrado, chamando estas duas características de material dobrado. Porém, para este trabalho a distinção deve ser feita porque as fendas possuem grafitas no seu interior enquanto pode haver material dobrado sem a influência da grafita na sua formação.

A figura 51 mostra as superfícies com 500 vezes de aumento. Nestas imagens não foram detectadas diferenças significativas entre as amostras de FV e FC. 


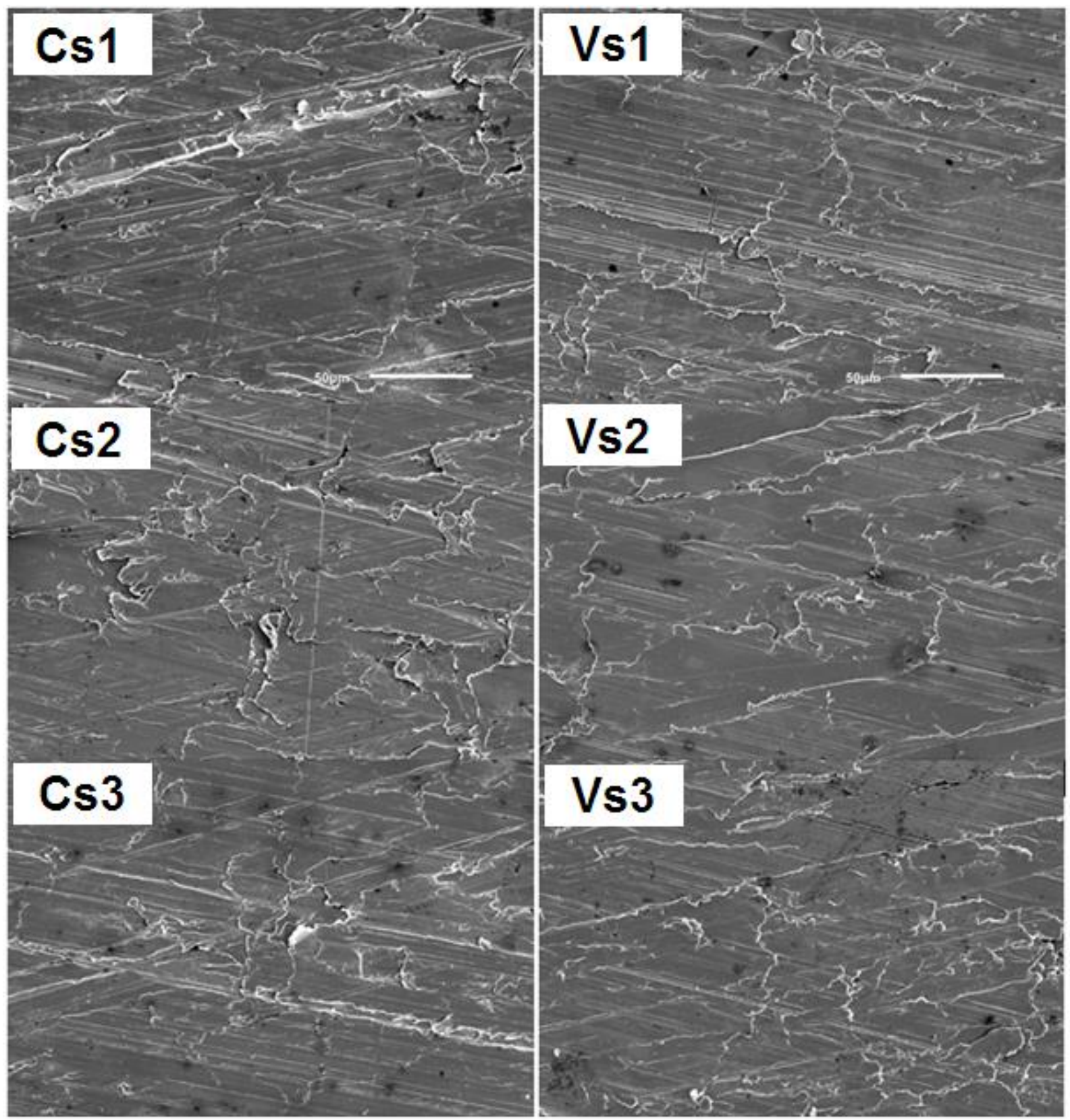

Figura 51 - Superfícies das amostras FC (à esquerda) e FV (à direita) antes dos tribotestes.

A tabela 16 traz os percentuais atômicos do carbono e do oxigênio obtidos através da análise de EDS das superfícies das amostras antes dos tribotestes. Os outros elementos formadores de tribofilme como zinco, fósforo e enxofre foram detectados em quantidades apenas residuais (entre 0 e 0,1 ). 
Tabela 16 - Quantidades (percentual atômico) de carbono e oxigênio nas superfícies das amostras antes dos tribotestes.

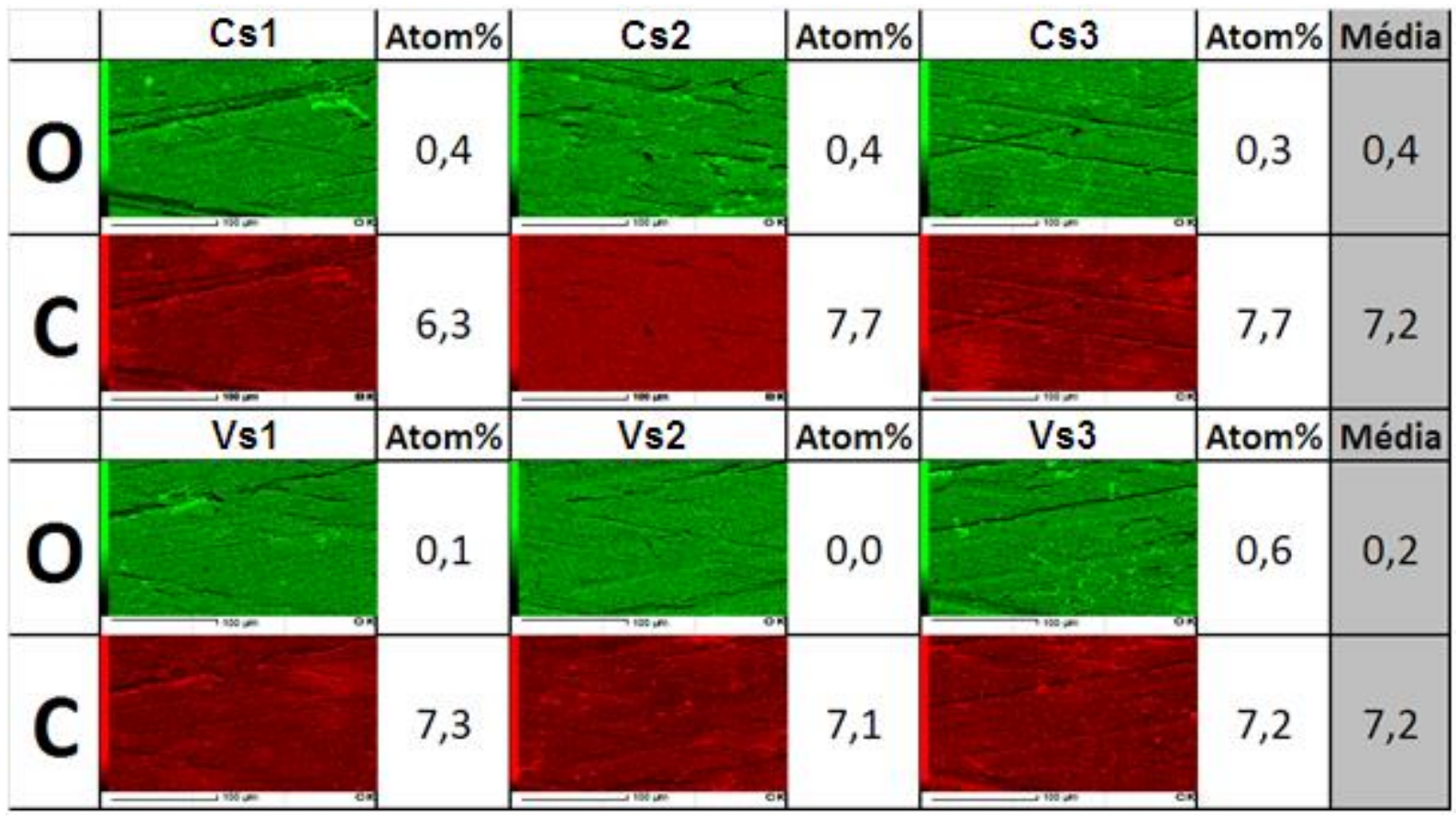

As imagens de MEV registradas após os ensaios dentro da trilha de desgaste, figura 52, mostram uma superfície bastante deformada plasticamente. Os riscos de brunimento nos platôs não são mais observados e os riscos mais profundos que delimitam os platôs estão quase que completamente recobertos por material deformado sobre eles. 


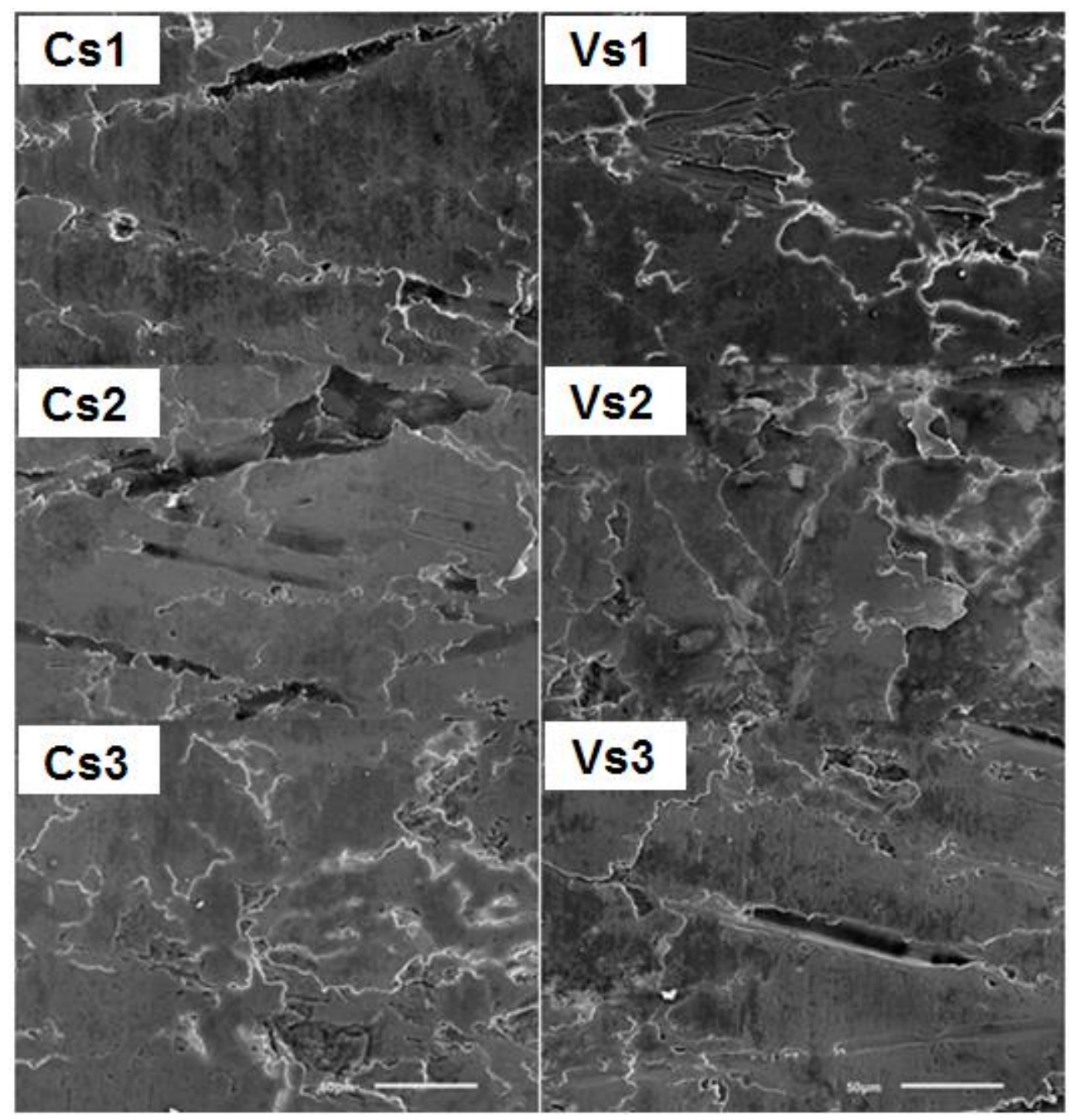

Figura 52 - Superfícies das amostras de FC (à esquerda) e FV (à direita) dentro da trilha de desgaste após o triboteste.

Há outra característica da morfologia da superfície após o triboteste: a presença de crateras. Aparentemente são porções de material removidas pelo mecanismo de desgaste por fadiga de contato. Estas crateras podem ser mais bem observadas na foto da figura 53. 


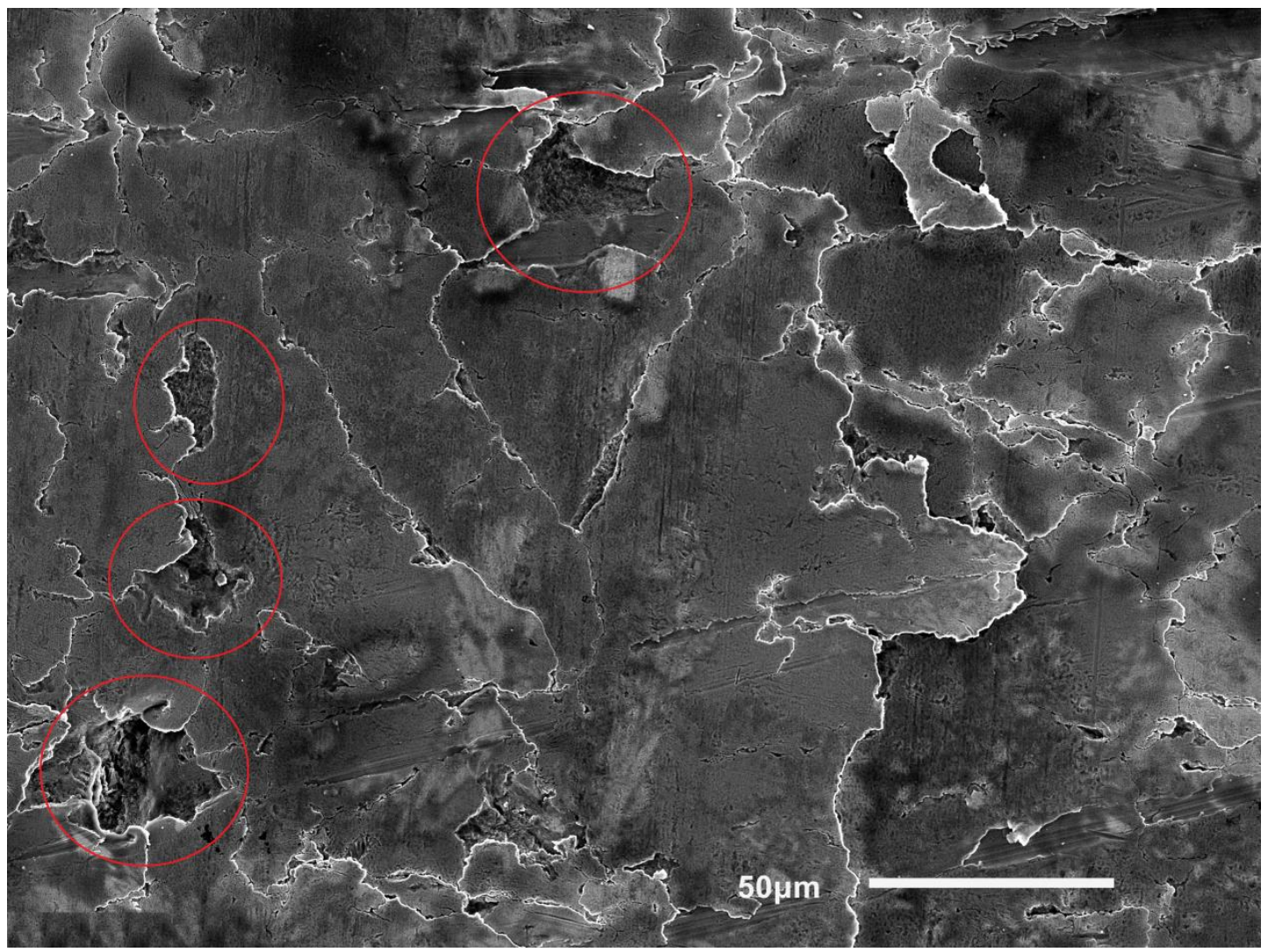

Figura 53 - Superfície da amostra Vs2 após o triboteste. Os círculos vermelhos indicam crateras, possivelmente geradas pelo mecanismo de desgaste de fadiga de contato.

A quantidade dos elementos formadores de tribofilme também é bem diferente da observada na superfície antes dos tribotestes o que indica a formação de um tribofilme bem constituído. Isto pode ser constatado analisando a tabela 17. Esta análise não evidenciou diferenças relevantes das quantidades de elementos formadores de tribofilmes entre as amostras de FV e FC. Outra informação importante pode ser obtida através da análise das imagens dos mapas. Nelas observa-se que os elementos formadores de tribofilme se encontram concentrados na mesma posição dentro da trilha de desgaste, evidenciando que o tribofilme é constituído de compostos formados por todos estes elementos. O Mo não aparece nos mapas porque as posições dos seus picos nos mapas de EDS se confundem com as posições dos picos de S. 
Tabela 17 - Quantidades dos elementos formadores de tribofilme e a sua distribuição em, uma região da trilha de desgaste, obtidas através de mapas de EDS.

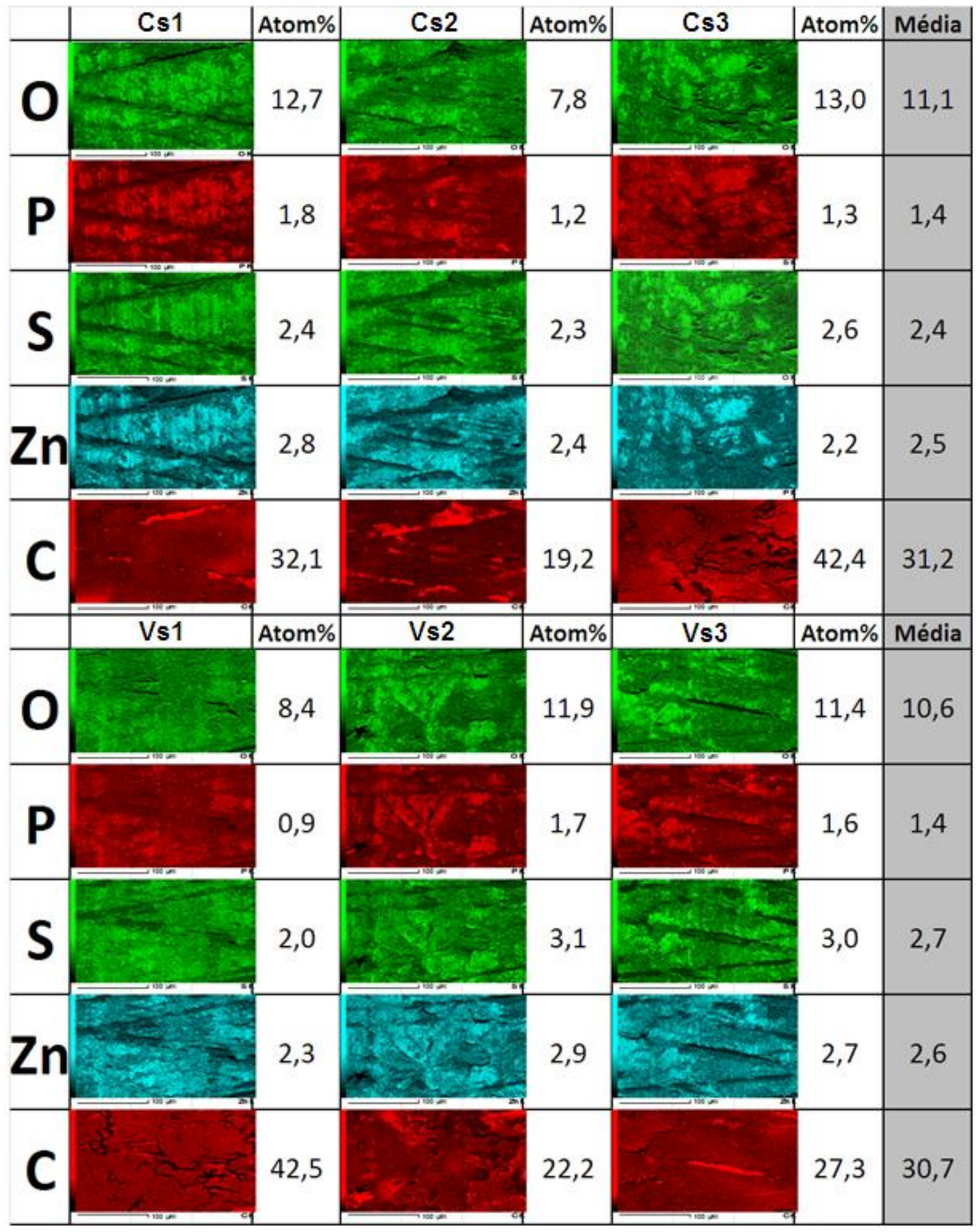

Como as análises de espectroscopia Raman detectaram a presença de $\mathrm{MoS}_{2}$ na camada mais externa do tribofilme, a quantidade de $S$ detectada pelo EDS pode ser atribuída, principalmente a este composto. Já o O, o Zn e o P, podem ser atribuídos 
a formação de cadeias de polifosfato a partir do ZDDP. Isto confirma as referências acerca dos tribofilmes formados a partir deste composto [22, 60 e 108] e sedimentado pela revisão de Spikes [20]. Portanto, há a formação de tribofilme de ZDDP e $\mathrm{MoS}_{2}$ na trilha de desgaste.

A tabela 18 mostra as quantidades dos elementos formadores de tribofilmes nas superfícies das amostras depois dos tribotestes e fora da trilha de desgaste. Os dados mostram que em relação aos valores obtidos nas análises das amostras antes dos tribotestes não há uma elevação significativa das quantidades dos elementos após os ensaios, com exceção do oxigênio. Isto indica que durante o ensaio há oxidação da superfície fora da trilha de desgaste, mas não há uma formação de filme bem constituído a partir dos aditivos dos óleos. A pequena elevação nas quantidades dos elementos $\mathrm{P}$, S e Zn pode ser atribuída ao resíduo de óleo presente na superfície que permaneceu após a limpeza das amostras. Logo, os aditivos MoDTC e ZDDP não formaram filmes fora da trilha de desgaste apenas pela ação térmica. 
Tabela 18 - Quantidades de O, P, S e C nas superfícies das amostras depois dos tribotestes e fora da trilha de desgaste.

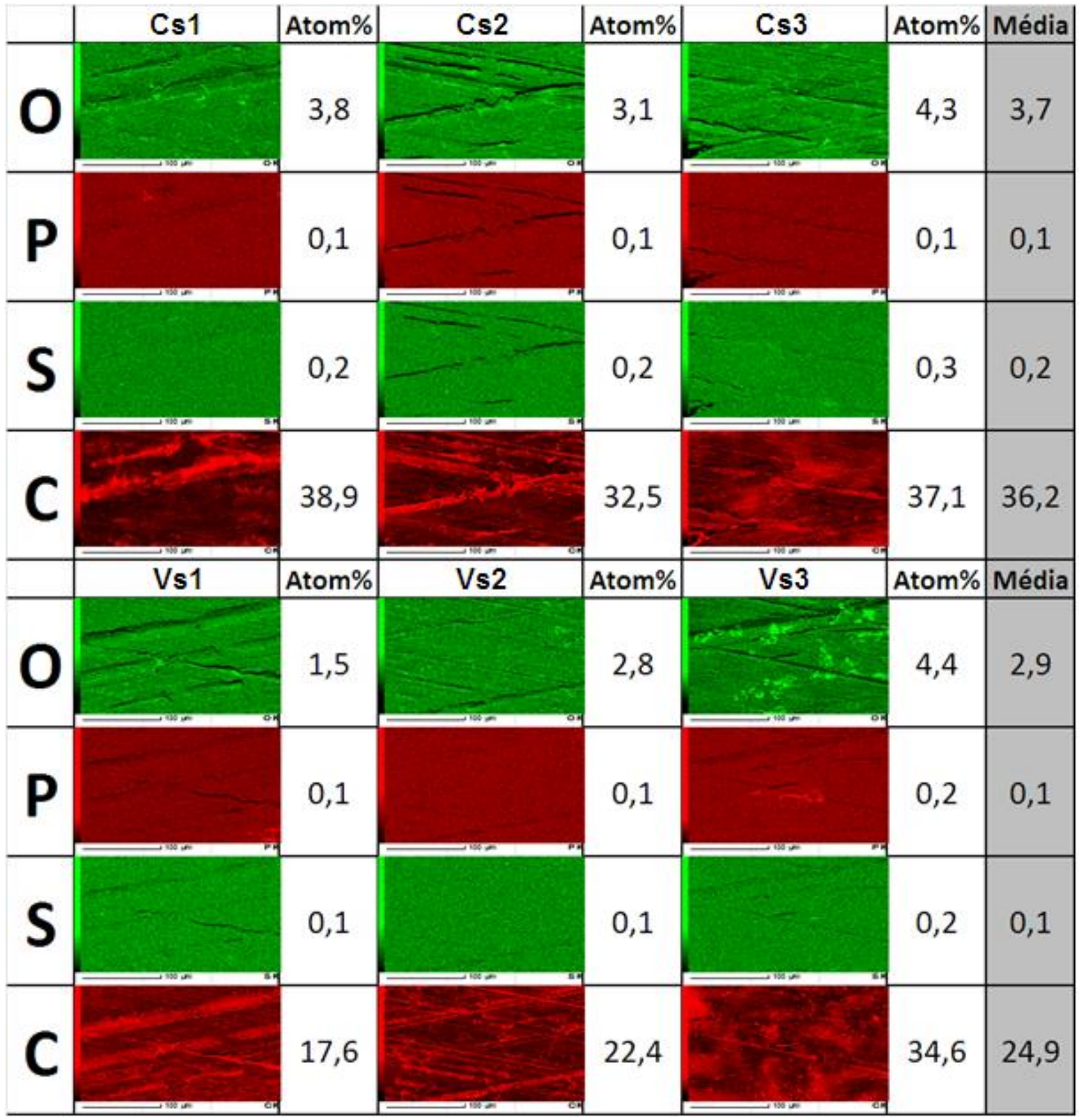

\subsubsection{Perfilometria ótica}

A análise dos resultados de perfilometria ótica será iniciada pelas imagens coletadas dentro das trilhas de desgaste das amostras. As imagens foram feitas no centro da trilha de cada amostra e estão apresentadas na figura 54. Uma análise qualitativa da superfície das amostras não permite encontrar diferenças entre as de FC e as de FV. Os dois grupos de amostras apresentam certa quantidade de riscos de 
brunimento que não foram removidos pelo processo de desgaste e crateras provenientes do processo de desgaste por fadiga de contato.

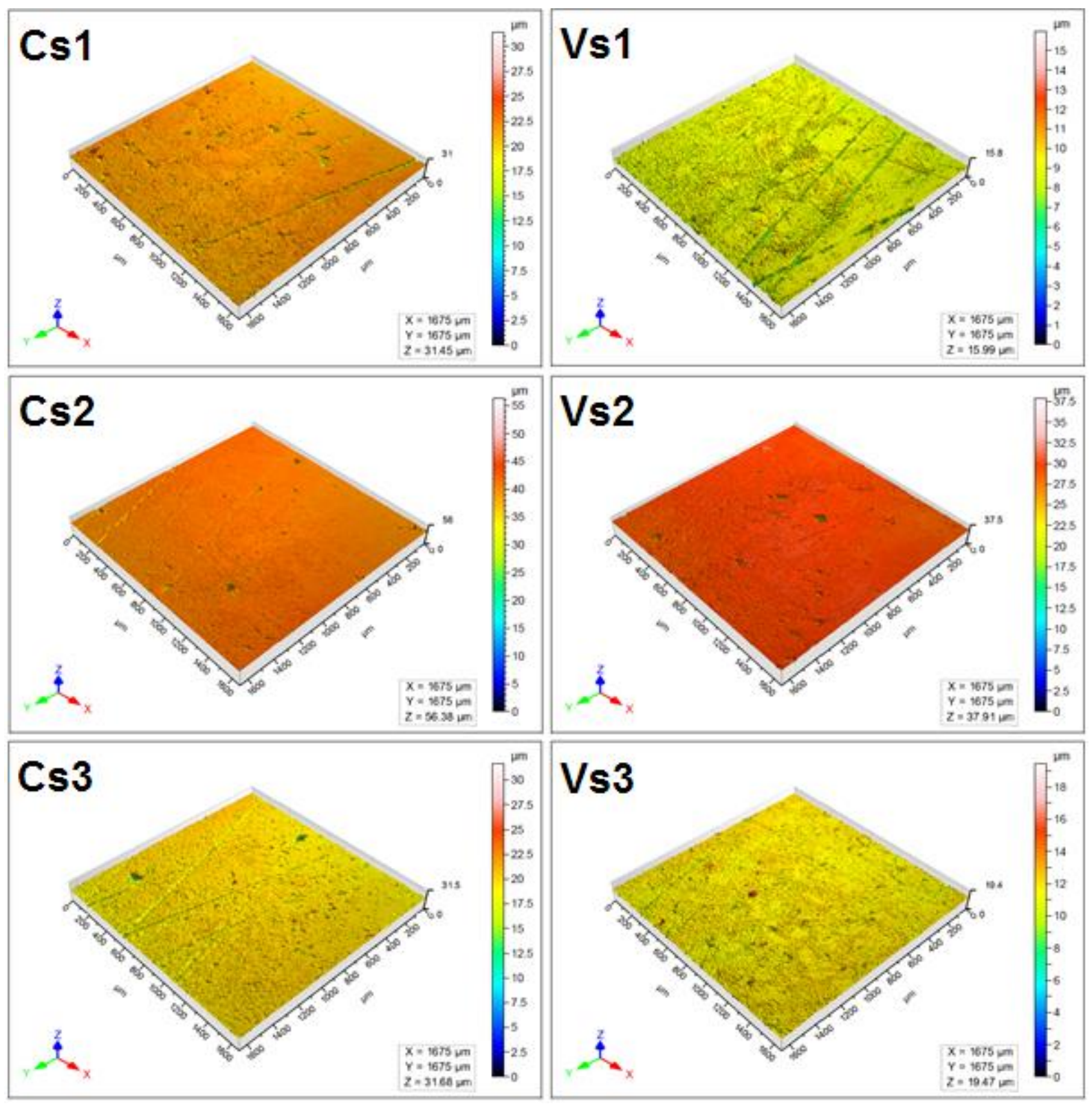

Figura 54 - Imagens do centro da trilha de desgaste das amostras de FC (à esquerda) e FV (à direita) geradas por interferometria ótica.

Os valores dos parâmetros de Greenwood e Williamson obtidos para as amostras FC e FV são apresentados na tabela 19. 
Tabela 19 - Valores dos parâmetros de Greenwood e Williamson calculados para as amostras de FC e FV antes dos tribotestes.

\begin{tabular}{c|cccccc}
\multicolumn{2}{c}{} & \multicolumn{2}{c}{ Zs } & \multicolumn{2}{c}{$\beta s$} & \multicolumn{1}{c}{$\boldsymbol{\eta}$} \\
\multicolumn{1}{c}{ Média } & Desvio & Média & Desvio & Média & Desvio \\
\cline { 2 - 7 } Cs2 & 0,45 & 0,12 & 23,20 & 5,68 & $1,55 \mathrm{E}+10$ & $1,38 \mathrm{E}+09$ \\
Cs3 & 0,39 & 0,06 & 20,29 & 1,94 & $1,27 \mathrm{E}+10$ & $2,18 \mathrm{E}+09$ \\
\hline Vs1 & 0,39 & 0,04 & 21,76 & 3,38 & $1,33 \mathrm{E}+10$ & $1,89 \mathrm{E}+09$ \\
\hline Vs2 & 0,18 & 0,02 & 22,45 & 2,98 & $1,16 \mathrm{E}+10$ & $1,13 \mathrm{E}+09$ \\
Vs3 & 0,16 & 0,01 & 19,11 & 2,76 & $1,07 \mathrm{E}+10$ & $1,41 \mathrm{E}+09$ \\
& 0,18 & 0,02 & 20,28 & 2,82 & $1,2 \mathrm{E}+10$ & $1,41 \mathrm{E}+09$
\end{tabular}

Os dados da tabela 19 e os gráficos da figura 55 mostram que o único parâmetro estatisticamente diferente entre as amostras de FC e FV é o que se refere à altura das asperezas $\left(Z_{S}\right)$. Isto indica que, como as durezas das matrizes dos materiais são muito próximas, as duas ligas proporcionam pressões de contato semelhante.

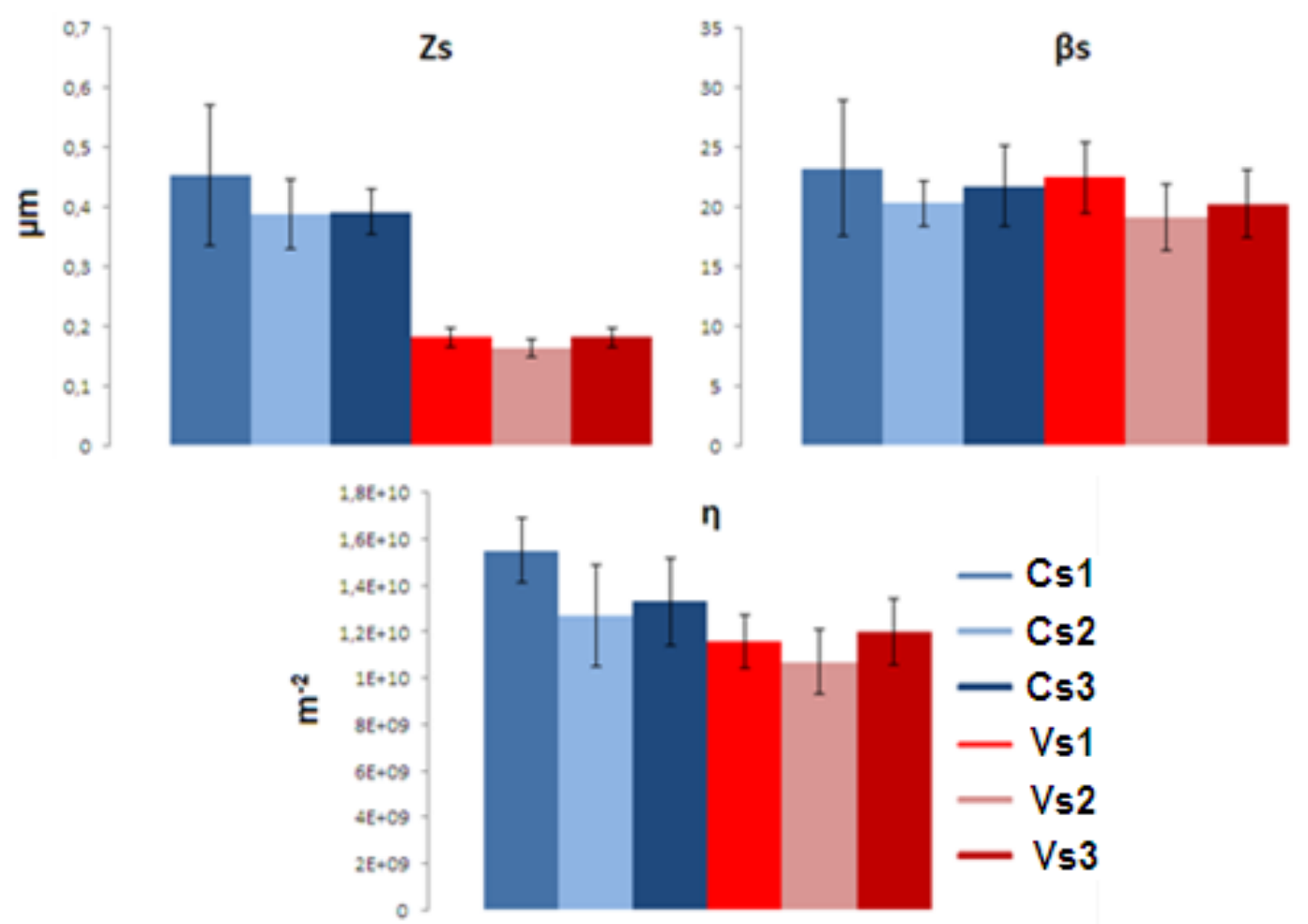

Figura 55 - Gráficos com os valores médios de $Z_{s}, \beta_{s}$ e $\eta$ e seus respectivos desvios padrão antes dos tribotestes.

A tabela 20 traz os valores dos parâmetros de Greenwood e Williamson para as amostras de FC e FV após o triboteste e dentro da trilha de desgaste. 
Tabela 20 - Valores dos parâmetros de Greenwood e Williamson calculados para as amostras de FC e FV depois dos tribotestes e dentro da trilha de desgaste.

\begin{tabular}{c|cccccc}
\multicolumn{1}{c}{} & \multicolumn{2}{c}{ Zs } & \multicolumn{2}{c}{ Bs } & \multicolumn{2}{c}{ N } \\
\cline { 2 - 7 } \multicolumn{1}{c}{} & Média & Desvio & Média & Desvio & Média & Desvio \\
\hline Cs1 & 0,29 & 0,09 & 95,16 & 18,46 & $2,69 \mathrm{E}+09$ & $8,07 \mathrm{E}+08$ \\
Cs2 & 0,37 & 0,1 & 79,23 & 25,2 & $2,10 \mathrm{E}+09$ & $3,96 \mathrm{E}+08$ \\
Cs3 & 0,38 & 0,09 & 66,55 & 12,18 & $2,51 \mathrm{E}+09$ & $2,67 \mathrm{E}+08$ \\
\hline Vs1 & 0,27 & 0,07 & 68,37 & 20,1 & $1,87 \mathrm{E}+09$ & $3,04 \mathrm{E}+08$ \\
Vs2 & 0,28 & 0,05 & 56,36 & 15,2 & $1,61 \mathrm{E}+09$ & $4,26 \mathrm{E}+08$ \\
Vs3 & 0,23 & 0,04 & 68,39 & 17,19 & $1,54 \mathrm{E}+09$ & $3,15 \mathrm{E}+08$
\end{tabular}

Analisando os dados da tabela 20 e os gráficos da figura 56 nota-se que as alterações dos parâmetros de Greenwood e Williamson pelo processo de desgaste são bastante acentuadas. As amostras de FC apresentaram redução do valor de altura média de pico $\left(Z_{s}\right)$, enquanto as amostras de $F V$ tiveram seu valor de $Z_{s}$ aumentado com o processo de desgaste. $O$ desgaste da superfície tornou os valores de $Z_{s}$ das amostras de $F C$ e $F V$ estatisticamente iguais. Já os valores do raio médio das asperezas $\left(\beta_{S}\right)$ e densidade de asperezas $(\eta)$ foram reduzidos praticamente na mesma proporção para os dois grupos de amostras. Isto significa que estes parâmetros continuaram estatisticamente iguais após os tribotestes apesar da alteração na superfície promovida pelo desgaste. É importante notar que a única amostra que pode ser considerada estatisticamente diferente em relação ao valor de $\eta$ é a Cs3 que apresenta valor de densidade de asperezas maior que as 3 amostras de FV. 

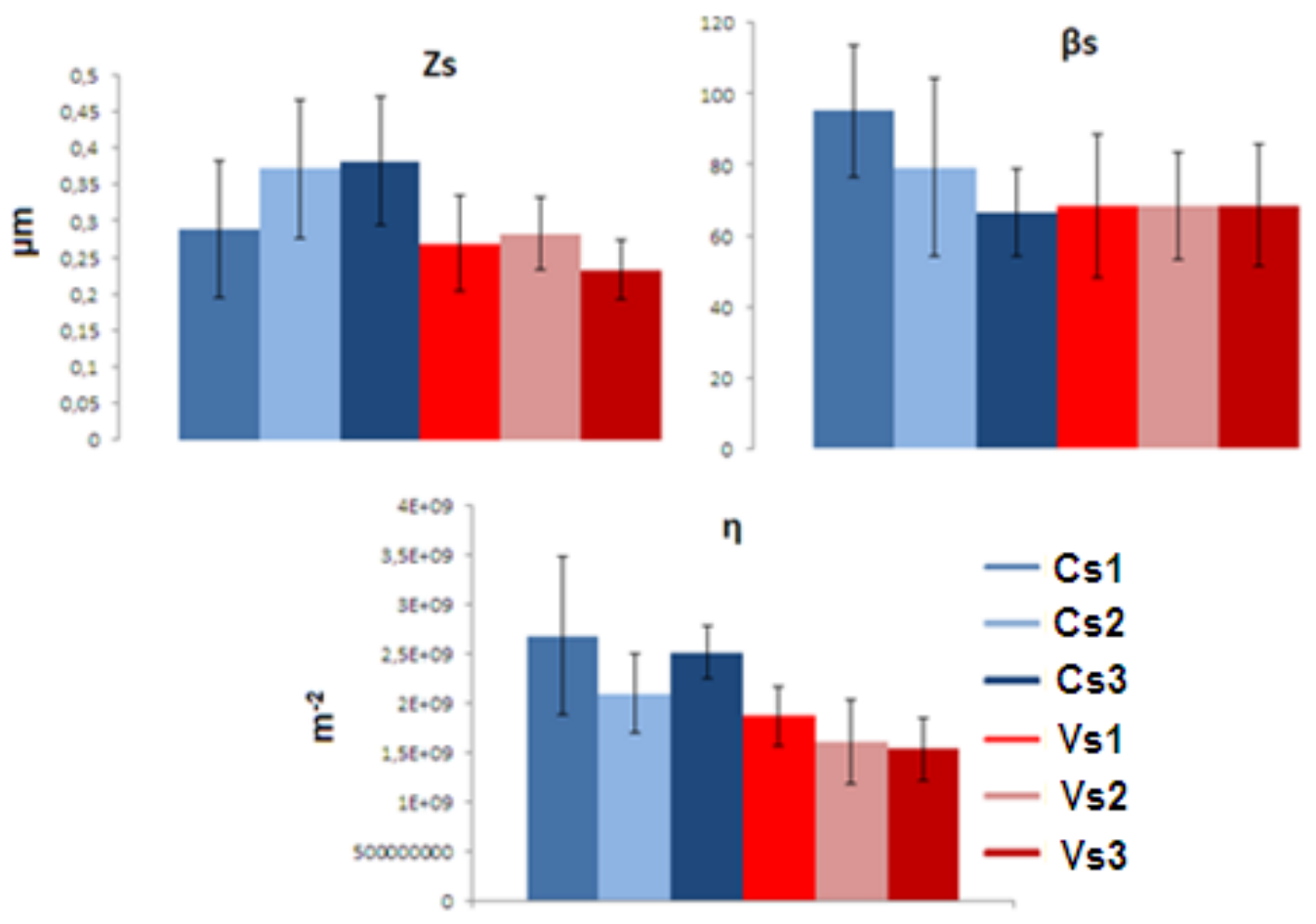

Figura 56 - Gráficos com os valores médios de Zs, $\beta$ s e $\eta$ e seus respectivos desvios padrão depois dos triboteste e dentro da trilha de desgaste.

A tabela 21 traz os valores das medições de degaste para as amostras de FC e FV. Não foi possível determinar nenhuma diferença de resistência ao desgaste entre as amostras de FC e FV. Apesar de haver diferenças significativas de desgaste entre as amostras elas não podem ser atribuídas ao tipo de ferro fundido.

Tabela 21 - Desgaste das amostras para as amostras de ferro fundido cinzento Cs1, Cs2 e Cs3 e para as amostras de ferro fundido vermicular Vs1, Vs2 e Vs3.

\begin{tabular}{c|c} 
& Desgaste $\left(\boldsymbol{\mu m}^{2}\right)$ \\
\hline Cs1 & 880,9 \\
Cs2 & 287,4 \\
Cs3 & 724,5 \\
\hline Vs1 & 498,0 \\
Vs2 & 372,3 \\
Vs3 & 438,4
\end{tabular}




\subsubsection{Triboteste}

A figura 57 traz o gráfico do coeficiente de atrito pico a pico para todas as amostras testadas. Como é possível observar há uma queda brusca no coeficiente de atrito devido a ativação do MoDTC no início do ensaio para todas as amostras. Este fenômeno também foi observado por outros autores [13, 26, 106]. Não é possível notar nenhuma diferença significativa no coeficiente de atrito entre as amostras testadas através deste gráfico.

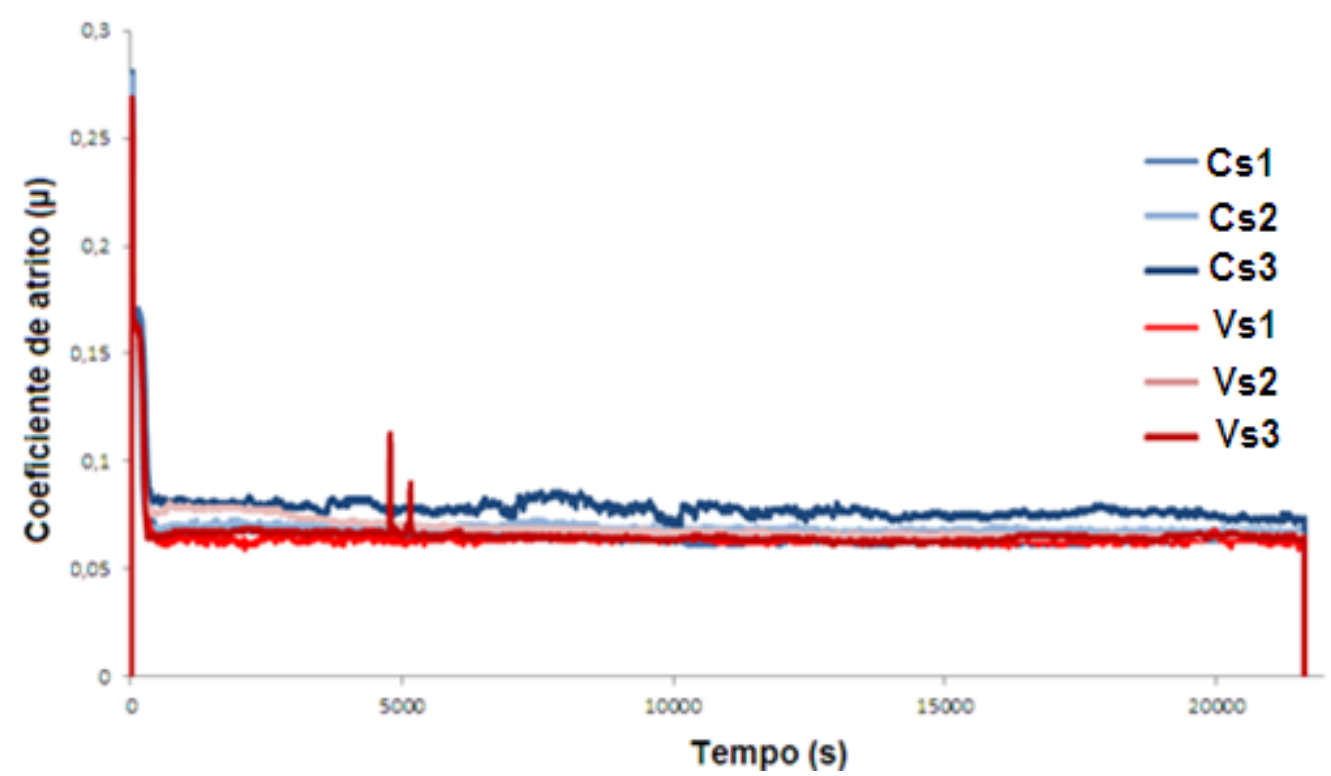

Figura 57 - Coeficiente de atrito registrado pela SRV para as amostras de ferro fundido cinzento (curvas azuis) Cs1, Cs2 e Cs3 e para as amostras de ferro fundido vermicular (curvas vermelhas) Vs1, Vs2 e Vs3.

A figura 58 traz o mesmo gráfico da figura 57, porém limitado aos primeiros 600 segundos de ensaio. Com isto, é possível observar com maiores detalhes as diferenças entre as amostras durante a queda no coeficiente de atrito (ativação do MoDTC). A principal diferença está no tempo de ativação do MoDTC para cada amostra. 


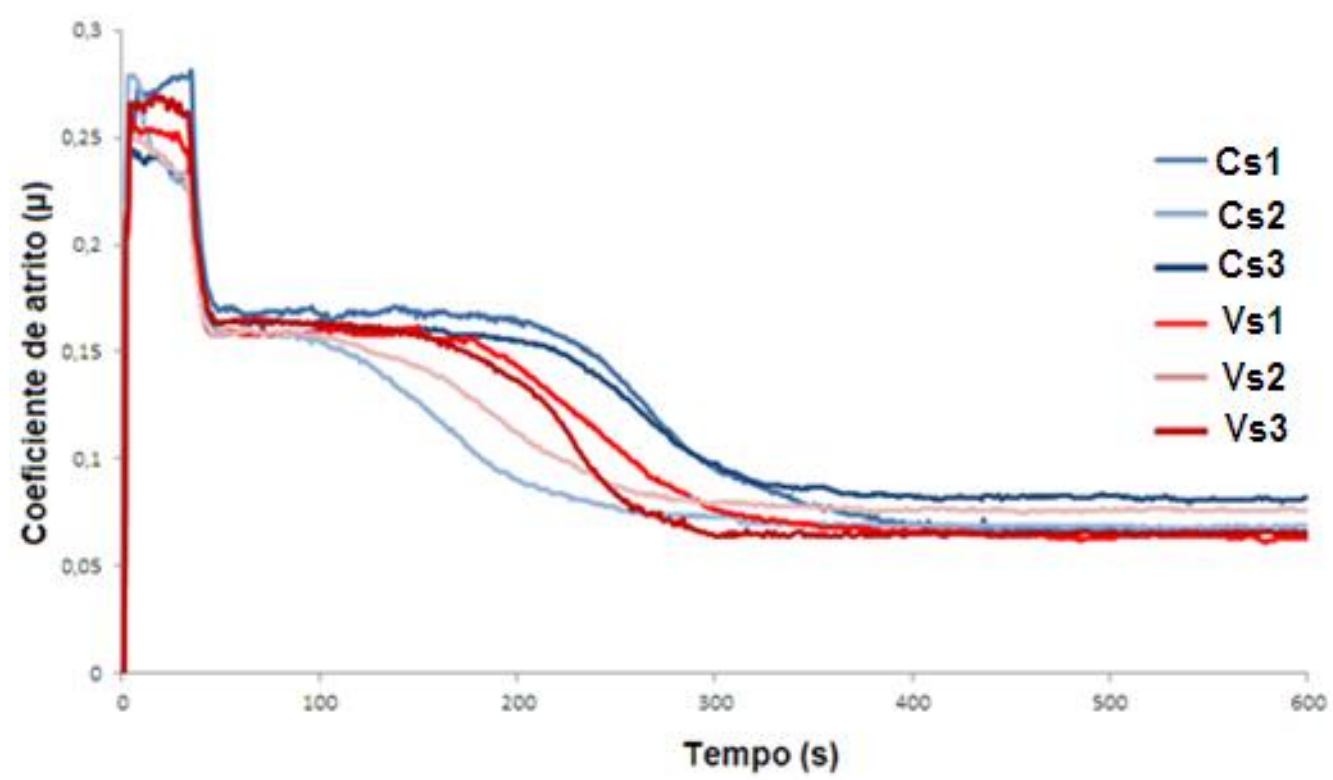

Figura 58 - Coeficiente de atrito registrado pela SRV para as amostras de ferro fundido cinzento (curvas azuis) Cs1, Cs2 e Cs3 e para as amostras de ferro fundido vermicular (curvas vermelhas) Vs1, Vs2 e Vs3. Ampliado nos primeiros 600 segundos de ensaio.

Com o intuito de comparar o tempo de ativação entre as amostras criou-se um parâmetro para determiná-lo. Este parâmetro será chamado de "tempo de ativação" e é determinado usando o valor de coeficiente de atrito encontrado através da equação 1. Uma vez determinado este valor de coeficiente de atrito, que corresponde a $50 \%$ da queda ocorrida na ativação, busca-se no gráfico dos ensaios quanto tempo foi necessário para que este fosse atingido.

Equação 1 $\frac{\text { coeficiente de atrito antes }+ \text { coeficiente de atrito depois }}{2}$

A tabela 22 mostra os tempos de ativação para as amostras FC e FV calculados usando a equação 1 .

Tabela 22 - Tempo de ativação das amostras FC e FV.

\begin{tabular}{c|c} 
& Tempo de ativação (s) \\
\hline Cs1 & 267 \\
Cs2 & 165 \\
Cs3 & 263 \\
\hline Vs1 & 243 \\
Vs2 & 194 \\
Vs3 & 223
\end{tabular}




\subsubsection{Conclusões parciais}

- Através da espectroscopia Raman foi possível concluir que as grafitas nodular, lamelar e vermicular não possuem diferenças significativas na relação $I_{D} / I_{G}$.

- Apesar da presença da ferrita na matriz do FV, esta, se encontra em quantidades muito pequenas, insuficientes para provocar diferença significativa de dureza entre as matrizes do FC e do FV.

- Não é possível atribuir diferenças de dureza superficial antes dos tribotestes ao tipo de ferro fundido usado para fabricar a amostra. As amostras podem ser consideradas estatisticamente iguais em relação a sua dureza. As duas exceções são a amostra Vs2 que possui dureza estatisticamente inferior às demais com seu desvio padrão se sobrepondo apenas ao da amostra Cs3 e a amostra Cs1 que pode ser considerada como tendo dureza superior às outras, tendo como única exceção a amostra Cs2 cujo desvio padrão se sobrepõe ao dela. As diferenças de dureza encontradas de uma amostra para a outra mesmo entre as amostras fabricadas com o mesmo tipo de ferro fundido podem ser atribuídas ao processo de brunimento a que elas foram submetidas. As amostras foram retiradas de várias regiões diferentes dos cilindros que não foram identificadas antes da sua fabricação. Parâmetros de brunimento como velocidade de corte, avanço e rotação da ferramenta variam ao longo do curso da ferramenta dentro do cilindro. Esta variação dos parâmetros pode promover diferentes graus de encruamento da superfície e consequentemente diferentes durezas superficiais resultantes.

- Em relação à dureza da superfície dentro da trilha de desgaste após o triboteste, há dois grupos de valores encontrados. As amostras podem ser consideradas iguais em dureza dentro do grupo, mas os dois grupos possuem durezas estatisticamente diferentes. O grupo de menor dureza contém as amostras Cs2, Cs3 e Vs2. Já o grupo de maior dureza possui as amostras Cs1, Vs1 e Vs3.

- Quando avaliadas as superfícies antes dos tribotestes foram detectadas grafitas nas fendas e nenhum pico foi encontrado nos platôs. Isto confirma análise da microestrutura de que as grafitas possuem acesso à superfície. 
- O único composto detectado por espectroscopia Raman na trilha de desgaste foi o $\mathrm{MoS}_{2}$. Isto significa que o topo do tribofilme é formado, principalmente, por este composto e que ele está bem distribuído pela superfície.

- Através das imagens de MEV não é possível detectar diferenças morfológicas significativas entre as superfícies das amostras de FC e FV. Depois dos ensaios as superfícies das amostras apresentam grande deformação plástica dentro das trilhas de desgaste, desgaste adesivo moderado e algumas crateras que aparentam ser decorrentes de desgaste por fadiga de contato. Além disto, parte dos riscos de brunimento mais profundos, que delimitam os platôs, estão preservados enquanto os riscos de menor profundidade, do topo dos platôs, foram removidos. Obara [7] identificou em seu trabalho a presença dos seguintes mecanismos de degaste na região do ponto morto superior: abrasão, desgaste por reações triboquímicas, fadiga de contato e adesão. Além disto, material deformado plasticamente sobre os riscos de brunimento. Santos Filho [12] identificou a presença dos mecanismos de adesão, abrasão, fadiga de contato e corrosão no ponto morto superior de cilindros que foram submetidos a ensaio de durabilidade. A figura 59 mostra, à esquerda, uma foto da região do ponto morto superior do cilindro analisado por Santos Filho [12]. À direita está a imagem da amostra Cs1 deste trabalho. Comparando as imagens e os mecanismos de desgaste descritos por Santos Filho [12] e Obara [7] é possível concluir que o ensaio com as amostras submersas em óleo reproduz adequadamente os mecanismos de desgaste por adesão e por fadiga de contato. Além disto, o nível de desgaste, que pode ser notado pelo grau de preservação dos riscos de brunimento, é bastante semelhante entre 0 que foi registrado por Santos Filho [12] e o observado nas amostras deste trabalho. Por isto, pode ser considerado que os ensaios com as amostras submersas em óleo reproduzem de maneira satisfatória as condições de operação do ponto morto superior de motores de combustão interna. 

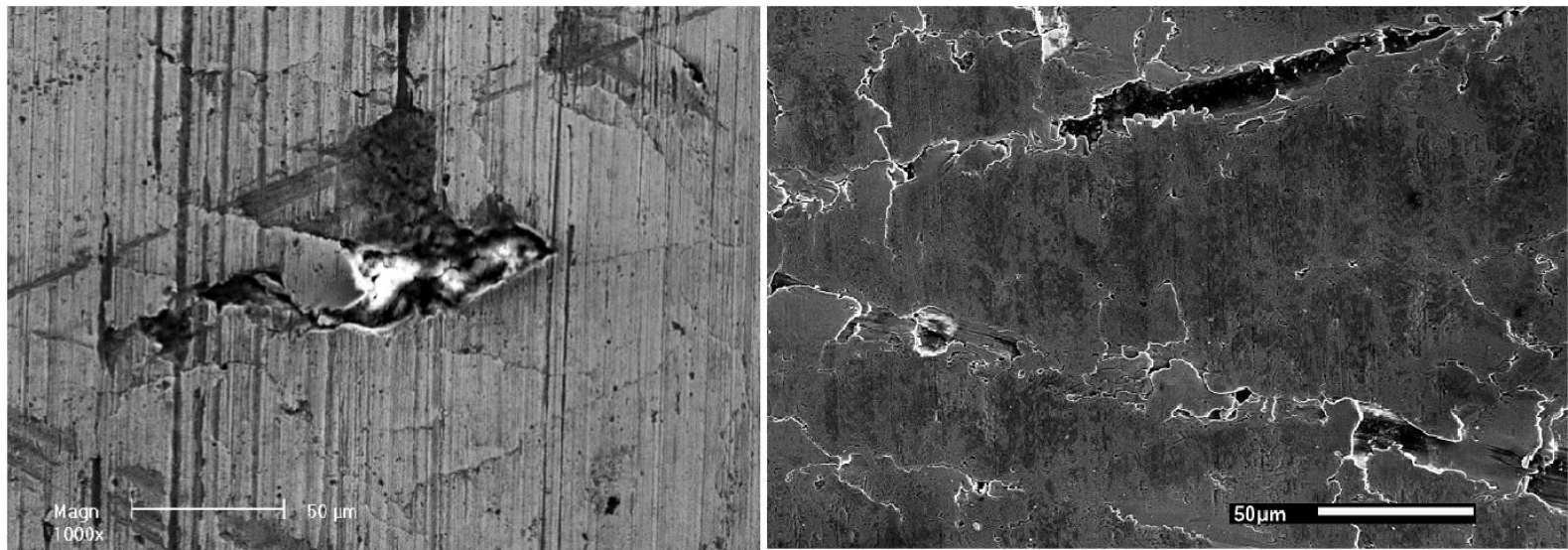

Figura 59 - À esquerda, superfície próxima ao ponto morto superior do cilindro após um ensaio de durabilidade [12]. À direita a superfície da amostra Cs1 após o ensaios em tribômetro.

- Em nenhuma das amostras foram encontradas, usando o EDS, quantidades significativas de oxigênio antes dos tribotestes. Os outros elementos formadores de tribofilmes que estão presentes nos aditivos dos óleos como $\mathrm{Zn}, \mathrm{P}, \mathrm{S}$ foram encontrados em quantidades desprezíveis, mostrando que as amostras eram praticamente isentas destes elementos antes dos tribotestes.

- Na trilha de desgaste foram encontradas quantidades significativas de O,P,S e $\mathrm{Zn}$ e eles encontravam-se concentrados em uma mesma região. Isto significa que o tribofilme é composto por todos estes elementos. Com esta informação e com o que há disponível na literatura é possível inferir que o tribofilme é formado por cadeias de polifosfato de zinco provenientes do ZDDP e no seu topo uma camada de $\mathrm{MoS}_{2}$ formada a partir do MoDTC. Além disto, os tribofilmes formados nas amostras de FC e FV não apresentaram entre si diferenças detectáveis pelas técnicas de caracterização utilizadas (EDS e Raman).

- As amostras de FC apresentaram maior altura média das $\left(Z_{s}\right)$ antes dos tribotestes. Porém, esta diferença não foi suficiente para tornar o desempenho tribológico do FC e do FV diferentes. Já o raio das asperezas $\left(\beta_{\mathrm{s}}\right)$ e a densidade de picos ( $\eta$ ) eram estatisticamente iguais para as duas amostras.

- As medições realizadas dentro da trilha de degaste mostraram que a única diferença no comportamento dos parâmetros de Greenwood e Williamson foi que nas amostras de $\mathrm{FC}$ os valores de $Z_{\mathrm{s}}$ apresentaram redução após o 
triboteste e nas amostras de FV o comportamento foi de aumento. Mas, os valores são considerados estatisticamente iguais.

- Houve diferença significativa no desgaste medido entre as amostras. Esta diferença não está relacionada ao tipo de ferro fundido usado na fabricação das amostras. Não foi identificada correlação entre desgaste e tipo de ferro fundido.

- O desgaste possui uma boa correlação com o tempo de ativação do MoDTC como mostra o gráfico da figura 60 . O valor de $R^{2}$ da curva é de 0,76.

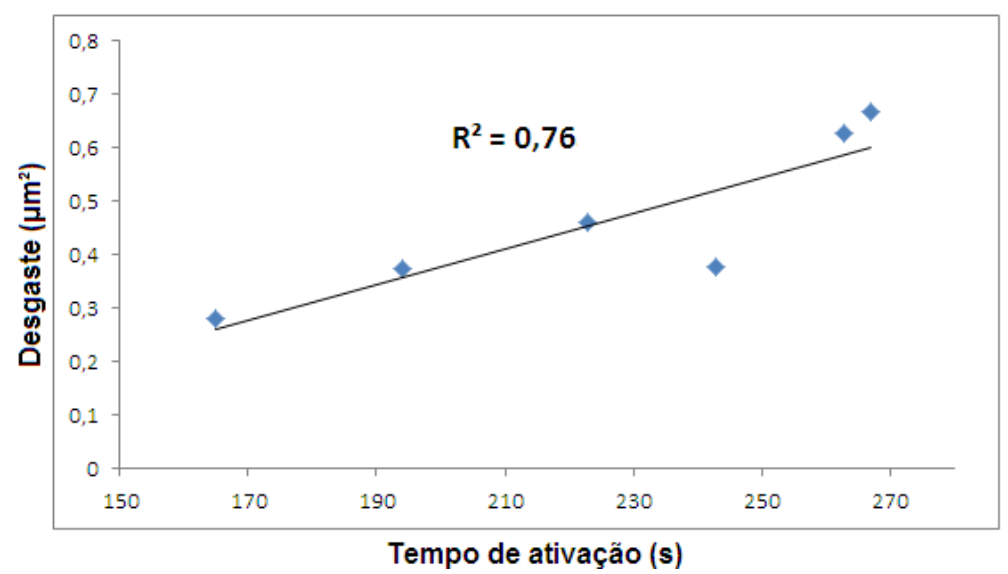

Figura 60 - Tempo de ativação versus desgaste.

- O fato de o desgaste ter boa correlação com o tempo de ativação e o desempenho tribológico do FC e FV serem tão próximos indicam que nas condições testadas o tipo de ferro fundido não é determinante para o desempenho tribológico do sistema. O que predomina é a atuação do tribofilme formado e, por isto, o tempo de ativação do MoDTC tem influência direta no nível de desgaste apresentado pela amostras após o triboteste. É importante salientar que $0 \mathrm{MoS}_{2}$, produto da ativação do MoDTC, se forma sobre o tribofilme de ZDDP. Por isto, a correlação entre desgaste e ativação do MoDTC não exclui a participação importante do tribofilme de ZDDP.

\subsection{Ensaios com apenas uma gota de óleo}

Os ensaios realizados com apenas uma gota aproximam o triboteste da condição de operação real do motor quando comparados com os ensaios executados com a 
amostra submersa em óleo. Existe o inconveniente de se trabalhar com uma quantidade fixa óleo. Em uma situação de operação normal de um motor de combustão interna a quantidade de óleo, apesar de pequena, é renovada constantemente. De qualquer maneira, a menor quantidade de óleo tende a aumentar a importância do material do cilindro no desempenho do tribossistema. Enquanto no triboteste com a amostra submersa em óleo não foi possível detectar diferenças de desempenho entre o FC e o FV porque este é determinado praticamente apenas pelo tribofilme, veremos que na configuração de teste utilizando apenas uma gota as diferenças de desempenho entre estes dois tipos de ferros fundidos são significativas.

\subsubsection{Microdureza Vickers}

A tabela 23 traz os valores das medições de dureza da superfície das amostras fora da trilha de e desgaste e dentro dela. Como na identificação das amostras dos ensaios com as amostras submersas em óleo as medições identificadas como superfície são de fora da trilha de desgaste enquanto as identificadas como trilha são de dentro da trilha de desgaste. Como esperado, os valores de microdureza medidos fora da trilha apresentam comportamento muito semelhante ao das amostras testadas submersas em óleo. Já as medições feitas dentro da trilha indicam que não há uma tendência definida de aumento da dureza após o ensaio, como aconteceu com as amostras testadas submersas em óleo. $\mathrm{Na}$ verdade, estatisticamente, não é possível dizer que os resultados de dureza dentro e fora da trilha são diferentes, pois os desvios padrão se sobrepõem. 
Tabela 23 - Microdureza da superfície e da trilha de desgaste das amostras válidas de FV e FC.

\begin{tabular}{|c|c|c|c|c|}
\hline \multirow{4}{*}{ Cg1 } & \multirow[b]{3}{*}{ superfície } & \multicolumn{3}{|c|}{ Dureza Vickers HV 0,1 } \\
\hline & & \multirow{2}{*}{$\begin{array}{c}\text { Média } \\
541 \\
\end{array}$} & \multirow{2}{*}{$\begin{array}{c}\text { Desvio } \\
86 \\
\end{array}$} & Aumento da dureza (\%) \\
\hline & & & & \multirow{2}{*}{-7} \\
\hline & trilha & 503 & 26 & \\
\hline \multirow{2}{*}{ Cg2 } & superfície & 442 & 96 & \multirow{2}{*}{22} \\
\hline & trilha & 541 & 65 & \\
\hline \multirow{2}{*}{ Vg1 } & superfície & 477 & 84 & \multirow{2}{*}{$-3,2$} \\
\hline & trilha & 462 & 53 & \\
\hline \multirow{2}{*}{ Vg2 } & superfície & 477 & 42 & \multirow{2}{*}{2,3} \\
\hline & trilha & 488 & 15 & \\
\hline
\end{tabular}

O gráfico da figura 61 relativo às medições de dureza antes do triboteste (superfície), mostra que as amostras podem ser consideradas estatisticamente iguais em relação a sua dureza. A única exceção é amostra Cg1 que possui dureza estatisticamente maior que as amostras $\mathrm{Cg} 2$ e $\mathrm{Vg} 2$.

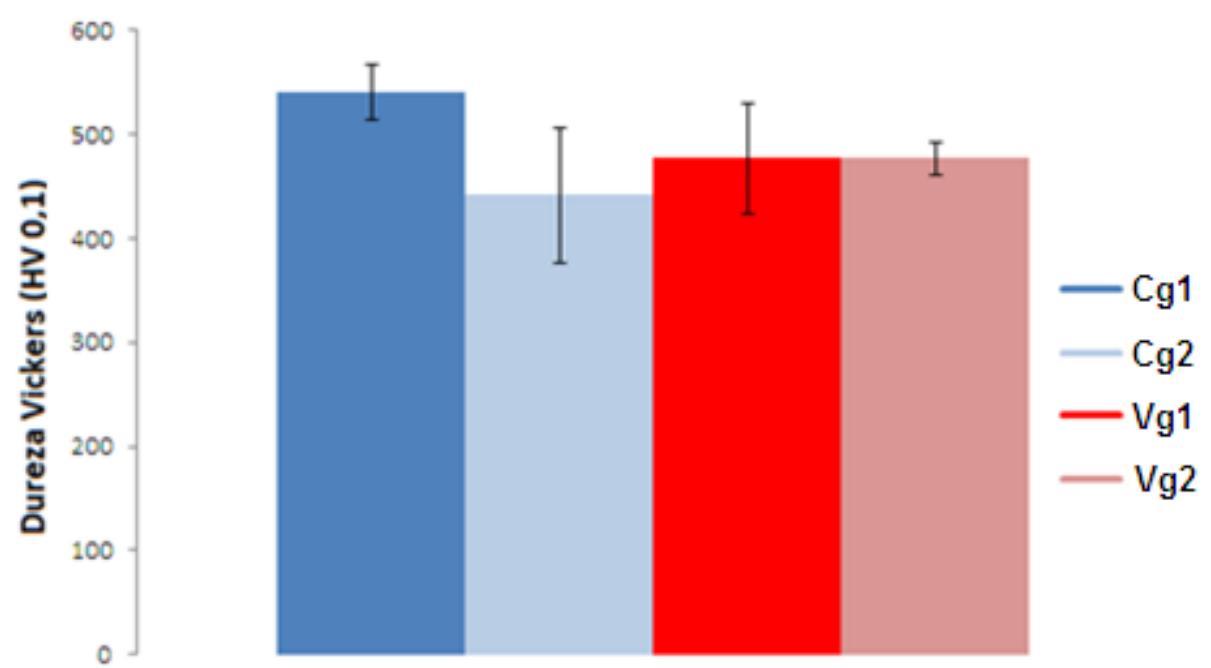

Figura 61 - Dureza da superfície das amostras FC e FV fora da trilha de desgaste.

O gráfico da figura 62 traz as medições de dureza dentro da trilha de desgaste e mostra que todas as amostras testadas nesta condição, (com uma gota de óleo por uma hora), são estatisticamente iguais. 


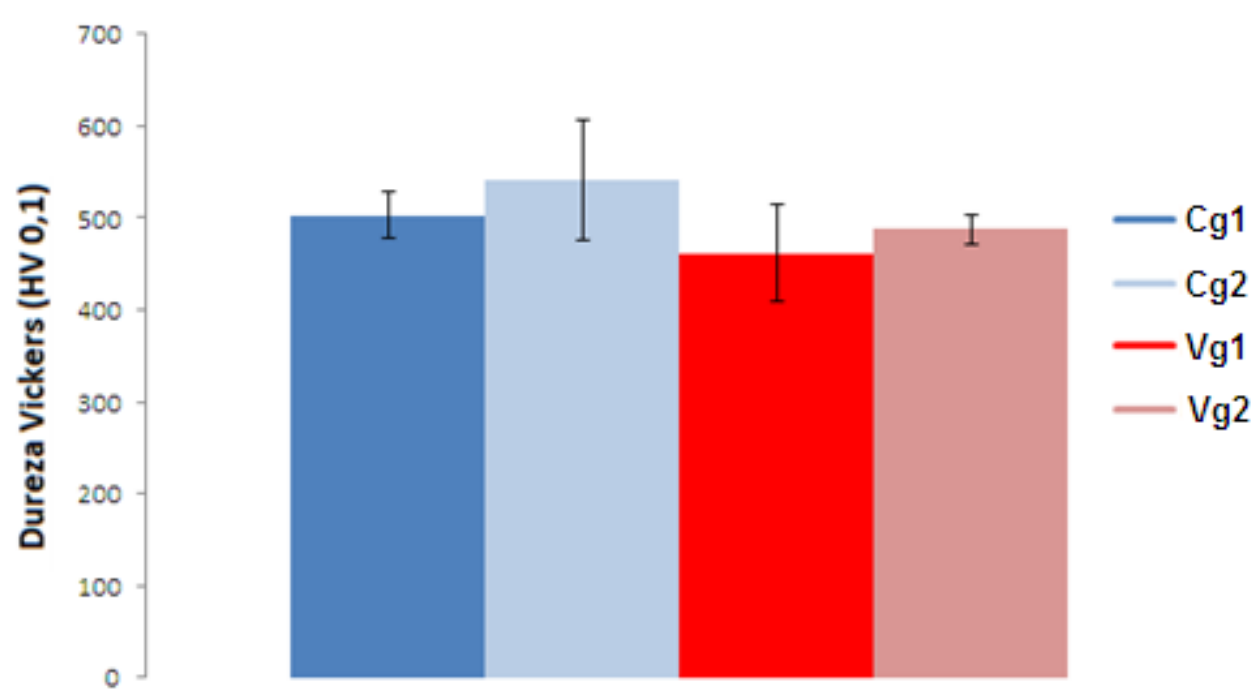

Figura 62 - Dureza da superfície das amostras FC e FV dentro da trilha de desgaste.

\subsubsection{Espectroscopia Raman}

Todas as amostras analisadas antes dos tribotestes com apenas uma gota de óleo apresentaram as mesmas características: Um espectro característico da grafita nas regiões de fenda e um espectro sem picos definidos nas regiões de platô, o que indica uma superfície metálica com pouca ou nenhuma oxidação. Os espectros de todas as amostras analisadas se encontram na figura 63 (fenda) e 64 (platô). 


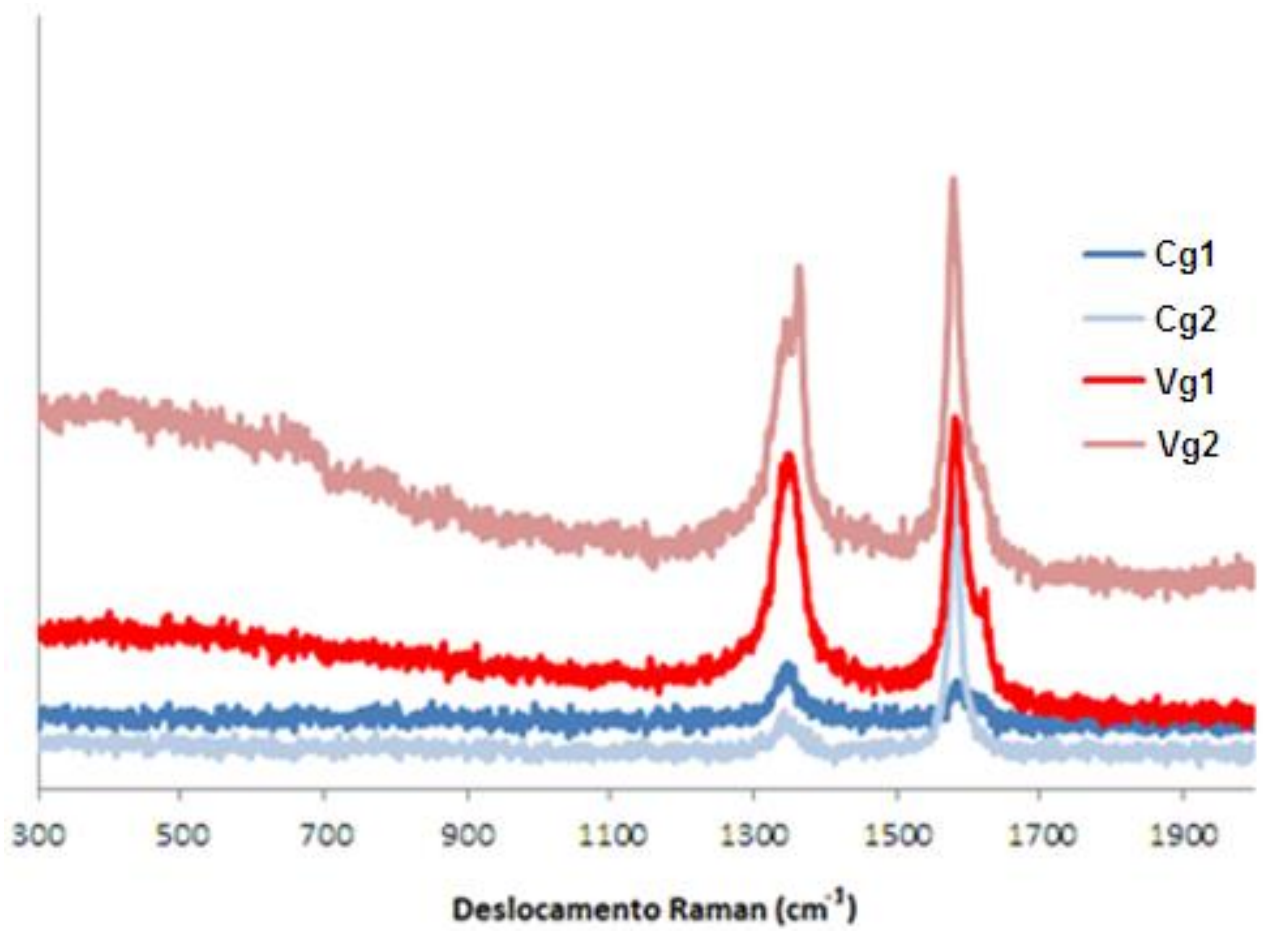

Figura 63 - Espectros Raman registrados nas fendas das amostras de FC (tons de azul) e FV (tons de vermelho).

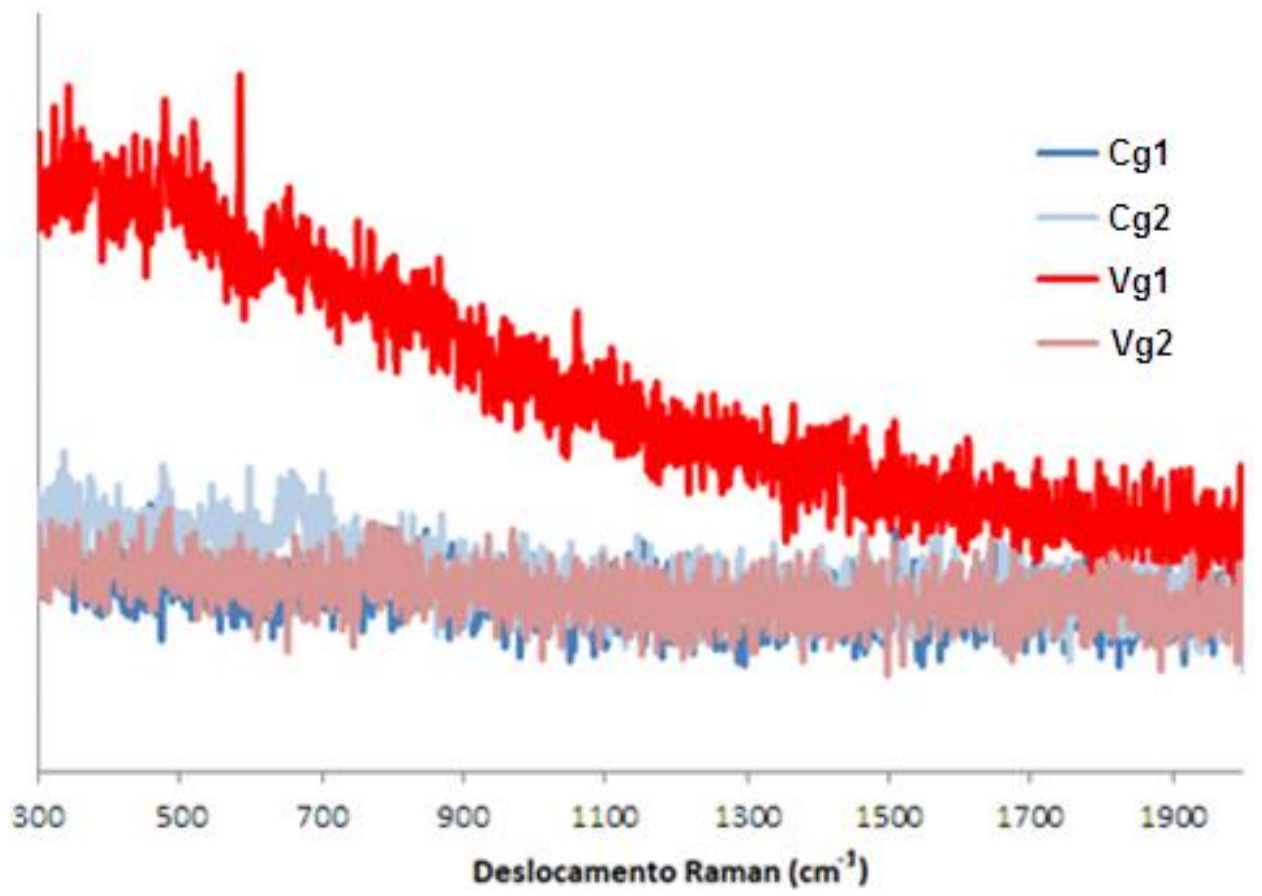

Figura 64 - Espectros Raman registrados nos platôs das amostras de FC (tons de azul) e FV (tons de vermelho).

Os espectros colhidos dentro das trilhas de desgaste também não mostraram diferenças significativas entre os compostos encontrados nas superfícies das 
amostras de FV e FC (figura 65). Todas as amostras apresentaram espectros semelhantes que combinam picos relativos à presença de hematita [16] $(219,286$ e 407), magnetita [16] (654) e grafita (1339 e 1605). Isto significa que, diferentemente das amostras testadas submersas em óleo, o filme de $\mathrm{MoS}_{2}$ formado a partir do MoDTC não esteve presente na superfície após o triboteste.

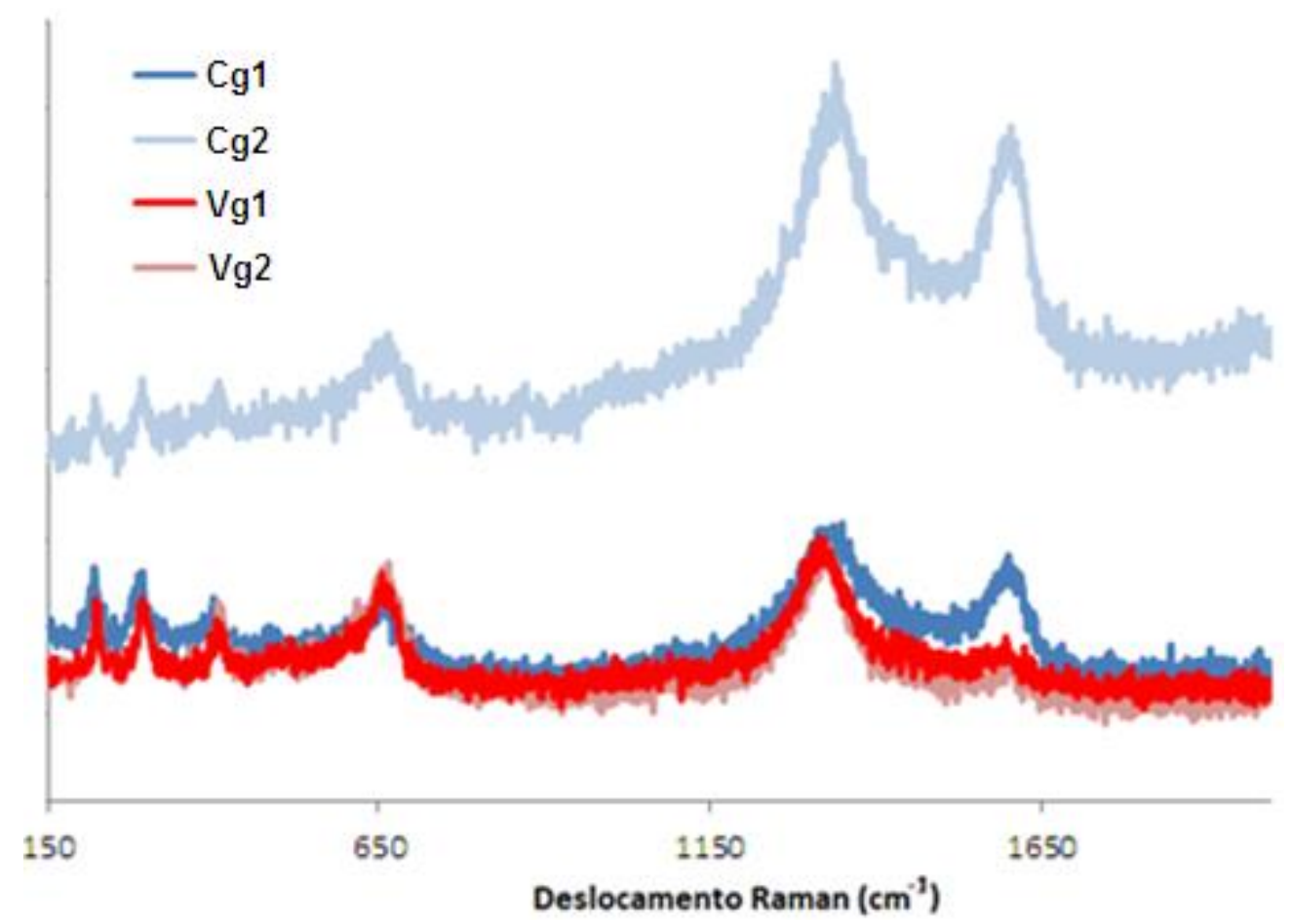

Figura 65 - Espectros registrados dentro da trilha de desgaste da amostra de FC (tons de azul) e FV (tons de vermelho).

Apesar de apresentarem os mesmos compostos os tribofilmes das amostras de FC e FV possuem uma diferença importante registrada nos espectros Raman. A diferença de intensidade dos picos relativos a banda $G$ entre os dois tipos de amostras é claro e está evidenciado na figura 66. Esta diferença de intensidade afeta a relação $\mathrm{I}_{\mathrm{D}} / \mathrm{I}_{\mathrm{G}}$. Abaixo seguem os valores de $I_{D} / l_{G}$ para cada amostra:

$$
\begin{aligned}
& >\mathrm{Cg} 1=1,1 \\
& >\mathrm{Cg} 2=1,1 \\
& >\mathrm{Vg}_{1}=1,8 \\
& >\mathrm{Vg} 2=1,6
\end{aligned}
$$

As amostras de FV possuem um valor de $\mathrm{I}_{\mathrm{D}} / \mathrm{I}_{\mathrm{G}}$ consideravelmente maior que as amostras de FC. 


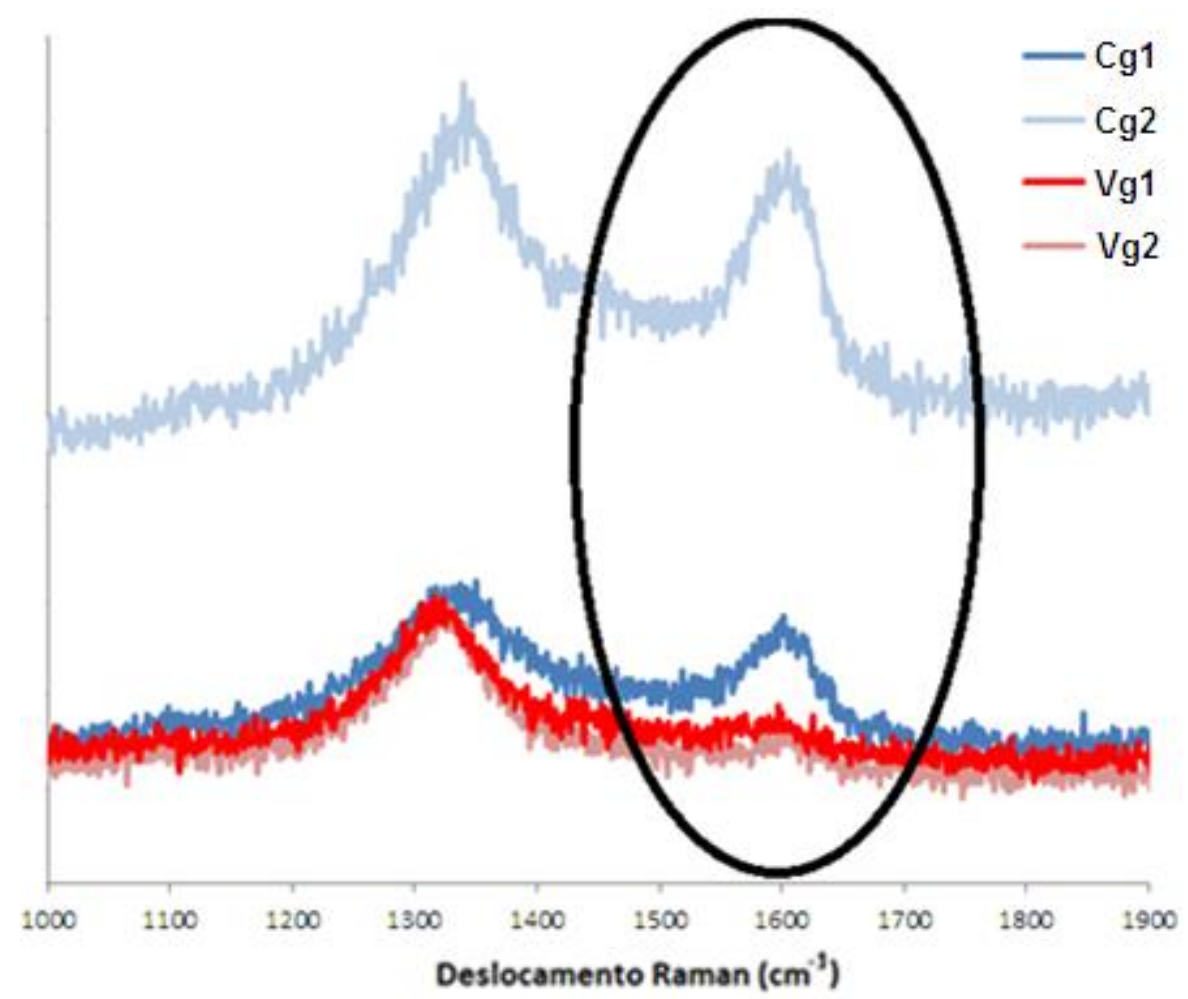

Figura 66 - Diferença de intensidade da banda G do espectro da grafita para as amostras de FC (azul) e FV (vermelho) após os tribotestes.

\subsubsection{Microscopia eletrônica de varredura}

A análise da morfologia da superfície das amostras antes dos ensaios mostra a configuração de uma superfície gerada pelo processo de brunimento de platô, assim como as usadas nos ensaios com a amostra submersa em óleo.

A figura 67 mostra as superfícies com 500 vezes de aumento. Nestas imagens não foram detectadas diferenças significativas entre as amostras de FV e FC. 


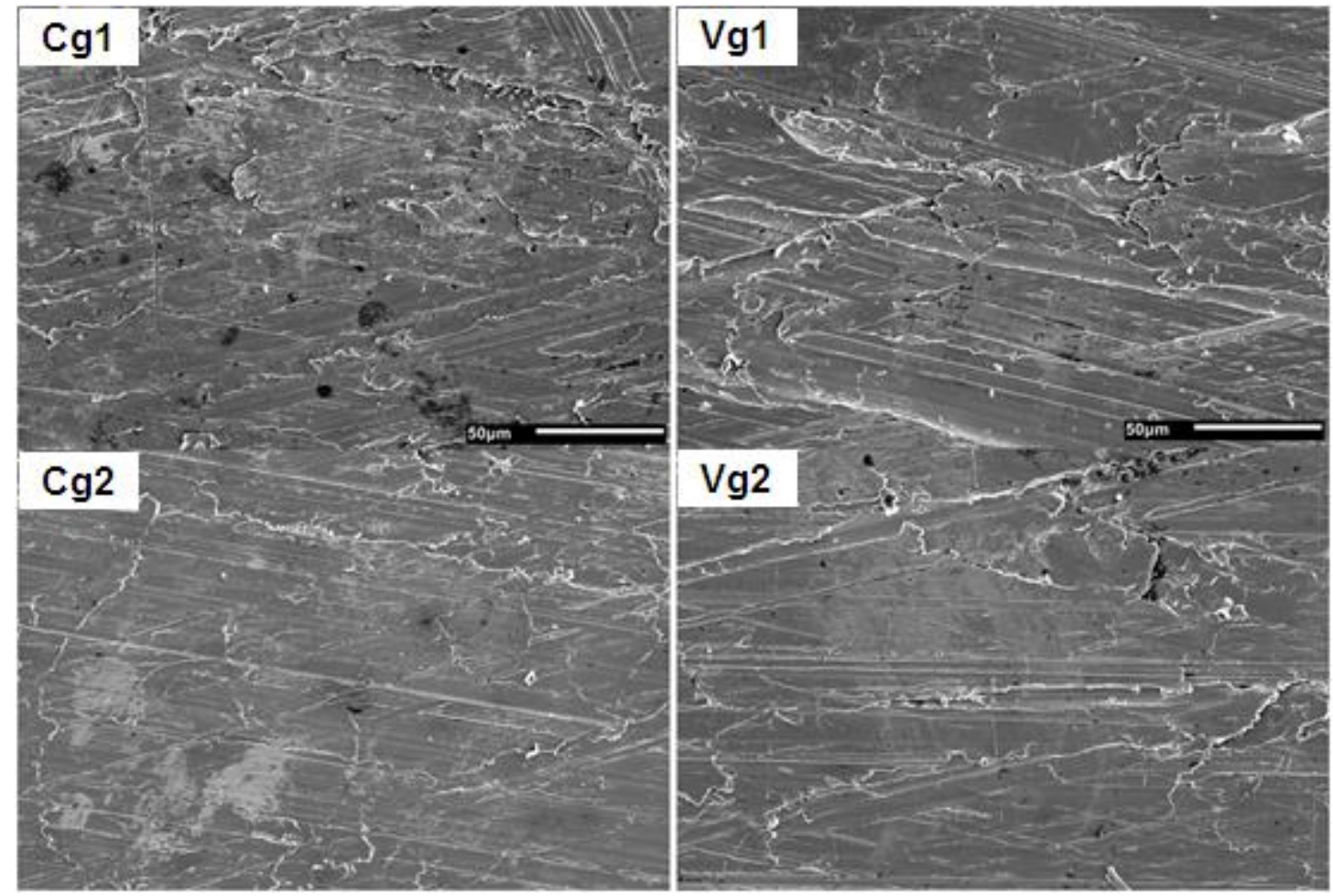

Figura 67 - Superfícies das amostras FC (à esquerda) e FV (à direita) antes dos tribotestes.

A tabela 24 traz os percentuais atômicos do carbono e do oxigênio obtidos através da análise de EDS das superfícies das amostras antes dos tribotestes. Os outros elementos formadores de tribofilme como zinco, fósforo e enxofre foram detectados em quantidades residuais (entre 0 e 0,1 ). 
Tabela 24 - Quantidades de carbono e oxigênio nas superfícies das amostras antes dos tribotestes.

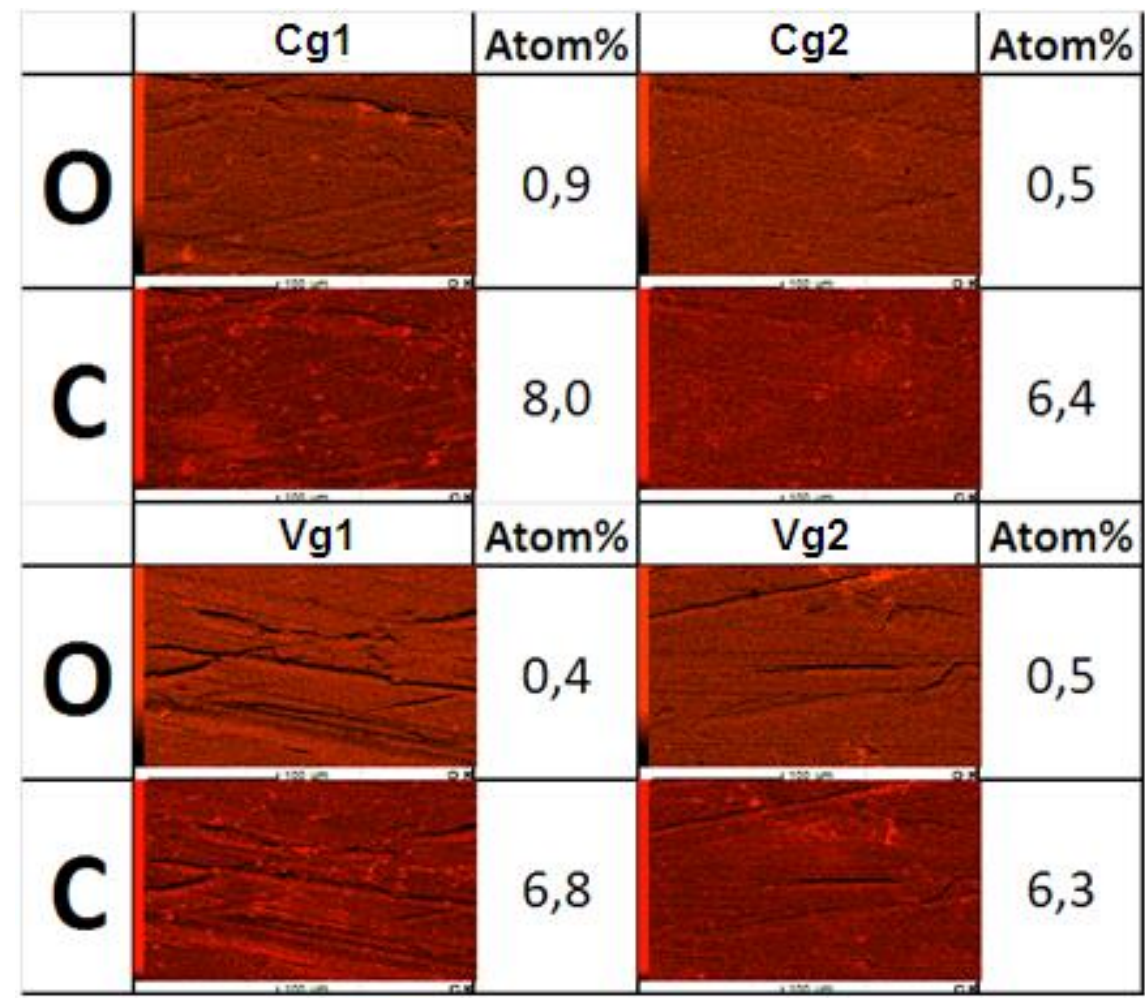

As imagens de MEV registradas após os ensaios dentro da trilha de desgaste, figura 68, mostram uma superfície bastante deformada plasticamente. Os riscos de brunimentos nos platôs não são mais observados e os riscos mais profundos que delimitam os platôs são observados apenas na amostra Vg2. 


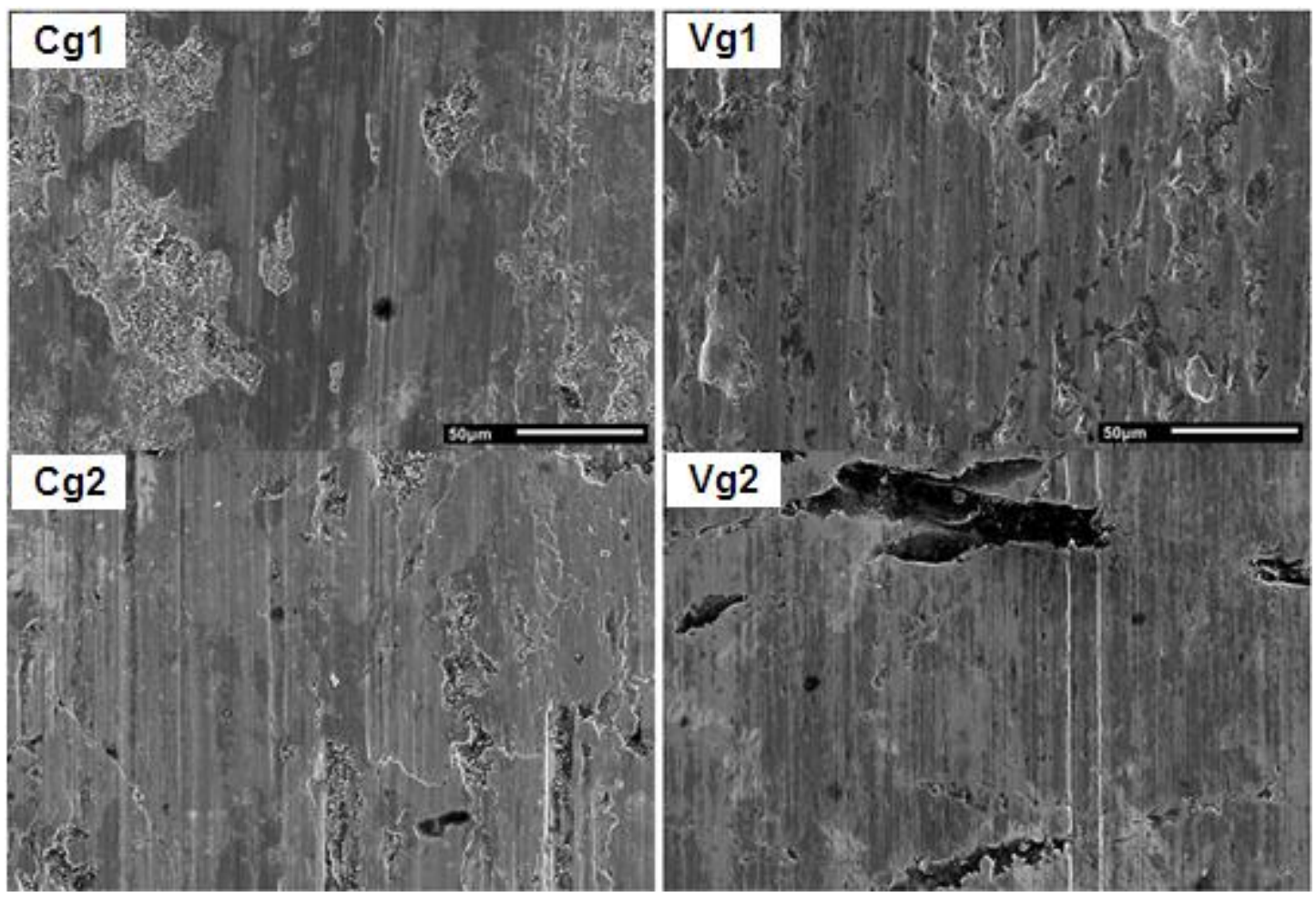

Figura 68 - Superfícies das amostras de FC (à esquerda) e FV (à direita) dentro da trilha de desgaste após o triboteste.

As amostras testadas com apenas uma gota de óleo, com exceção da amostra Vg2, também apresentaram crateras na sua superfície dentro da trilha de desgaste. Porém, as características das crateras, neste caso, denotam a ocorrência de desgaste adesivo severo enquanto as amostras testadas submersas em óleo possuíam crateras geradas, possivelmente, pelo mecanismo de fadiga de contato. A presença das crateras está destacada na figura 69. 


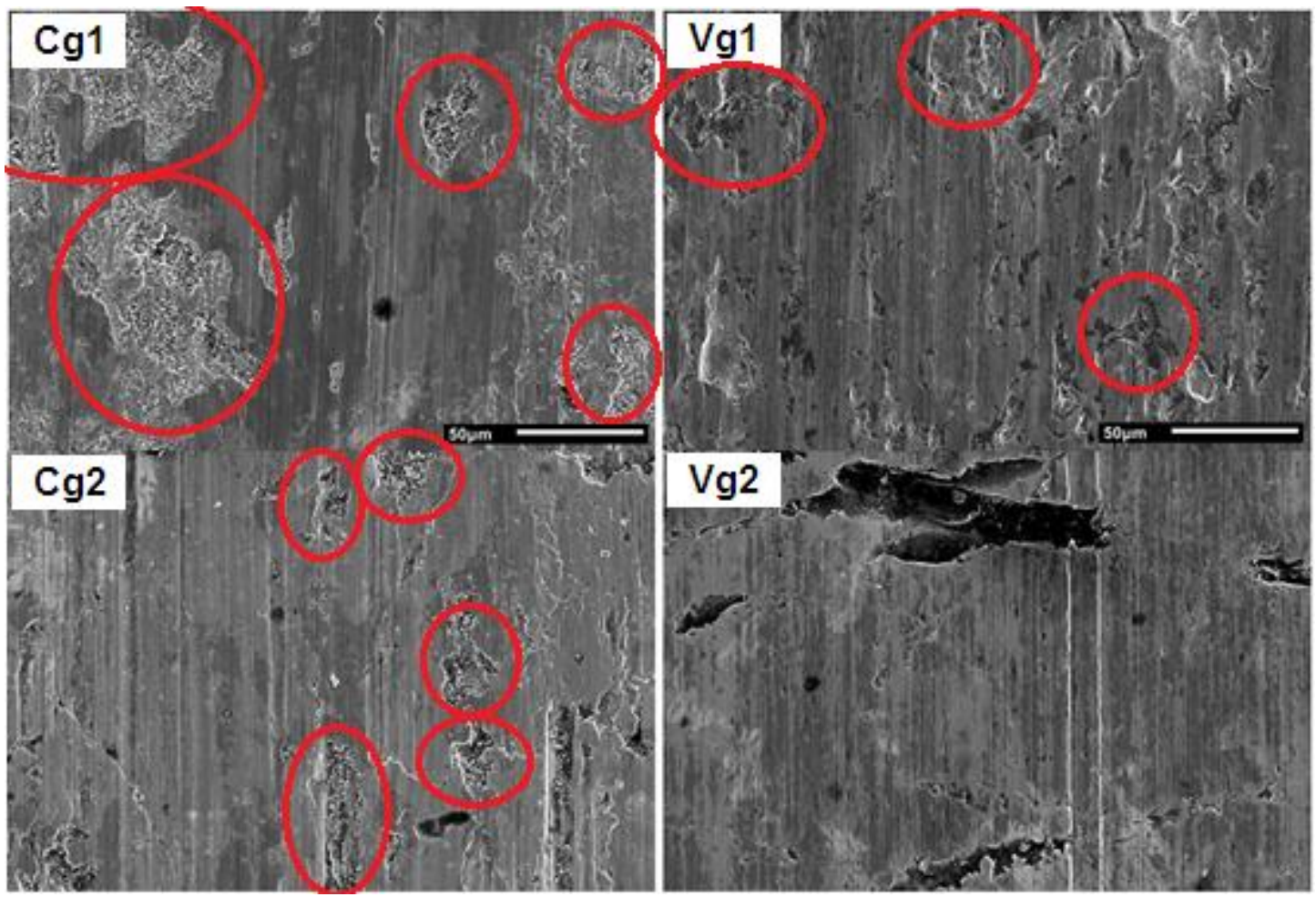

Figura 69 - Superfícies das amostras de FC (à esquerda) e FV (à direita) dentro da trilha de desgaste após o triboteste com as crateras identificadas em vermelho.

As análises de MEV/EDS da superfície das amostras testadas com apenas uma gota de óleo durante uma hora (tabela 25) mostram que os elementos formadores de tribofilme $\mathrm{P}, \mathrm{S}$ e $\mathrm{Zn}$ estão presentes apenas em quantidades residuais $(\leq 0,1 \mathrm{em}$ percentual atômico). A exceção é a amostra $\mathrm{Vg} 2$ que ainda possuía 0,6 de $\mathrm{P}, 0,6$ de $\mathrm{S}$ e $0,5 \mathrm{de} \mathrm{Zn}$ em percentual atômico. Isto explica a ausência de crateras e a preservação dos riscos de brunimento na superfície desta amostra e significa que o desgaste adesivo severo só ocorre após a remoção do tribofilme. A quantidade de $\mathrm{O}$ e C da amostra Vg2 não se difere das demais porque estes elementos não são fornecidos pelo óleo e, por isto, não são afetados pela falta de óleo ou pela remoção do tribofilme. 
Tabela 25 - Quantidades dos elementos formadores de tribofilme e a sua distribuição em, uma região da trilha de desgaste, obtidas através de mapas de EDS.

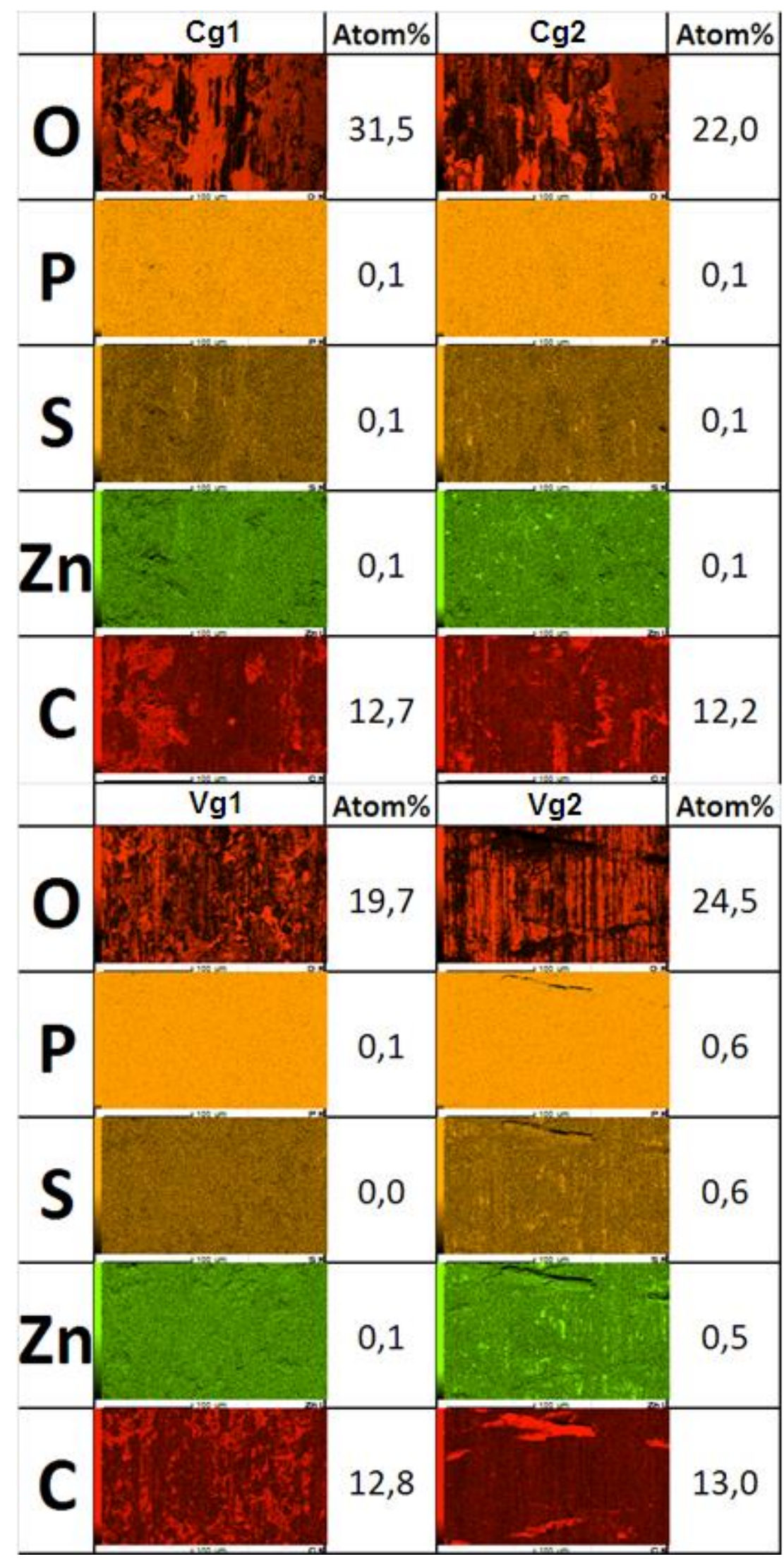


As análises de espectroscopia Raman não detectaram $\mathrm{MoS}_{2}$ na superfície das amostras testadas com apenas uma gota de óleo pelo período de uma hora. Isto significa que ao final do ensaio este composto não estava presente na superfície, nem mesmo na amostra $\mathrm{Vg}$ 2, que ainda preservava um tribofilme composto por $\mathrm{P}, \mathrm{S}$ e Zn. Provavelmente, este tribofilme era formado predominantemente, de cadeias de polifosfato formadas a partir do ZDDP.

\subsubsection{Perfilometria ótica}

As imagens das superfícies geradas após os tribotestes e dentro da trilha de desgaste (figura 70) mostram que há diferenças consideráveis entre as amostras de FC e FV. As primeiras possuem características de uma superfície bastante deformada e que sofreu desgaste adesivo severo. Nestas, não restaram riscos gerados pelo processo de brunimento, pois foram removidos pelo processo de desgaste. Já as amostras de FV passaram por um processo de desgaste moderado, preservando uma quantidade considerável de riscos de brunimento. É importante salientar que as imagens evidenciam diferenças também entre as duas amostras de FV. A amostra Vg1 preservou bem menos riscos de brunimento do que a amostras $\mathrm{Vg}$ 2. Além disto, a amostra $\mathrm{Vg} 1$ apresenta algumas crateras que indicam início de desgaste adesivo severo. 


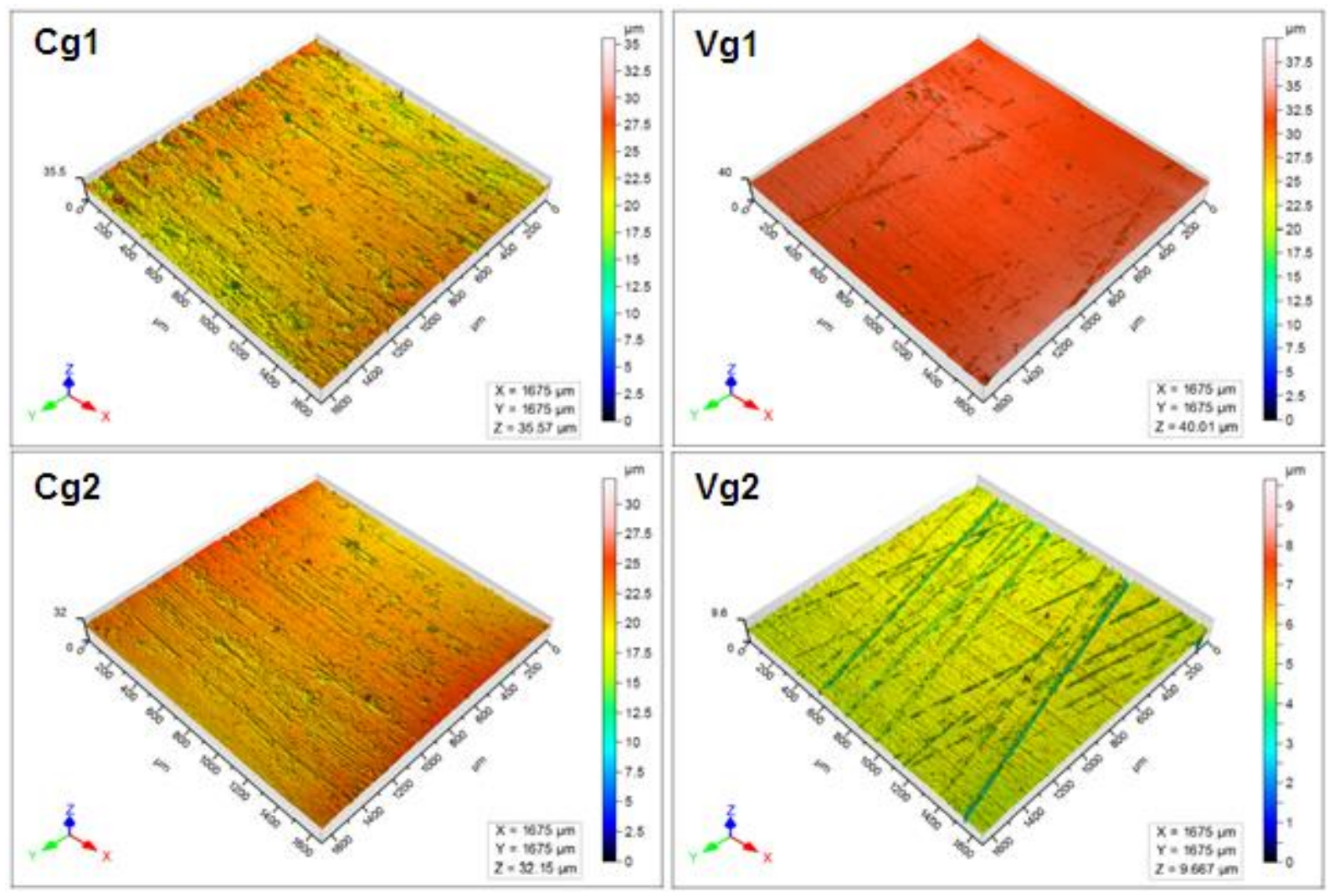

Figura 70 - Imagens do centro da trilha de desgaste das amostras de FC (à esquerda) e FV (à direita) geradas por interferometria ótica.

Nos testes realizados com apenas uma gota de óleo os valores de Greenwood e Willianson não serão apresentados. Há uma razão principal para esta análise se tornar dispensável: O parâmetro usado para analisar a resistência do desgaste da superfície nestes ensaios é a resistência ao scuffing e não a medição de desgaste propriamente dito e a morfologia da superfície após o ensaio.

\subsubsection{Triboteste}

O gráfico da figura 71 mostra as curvas de coeficiente de atrito para o ensaio com 1 hora de duração e apenas uma gota de óleo para a lubrificação do tribossistema. Nestas condições de ensaio ficou estabelecido que caso fosse atingido o valor de 0,5 para o coeficiente de atrito $o$ teste deveria ser interrompido para proteger $o$ equipamento. 


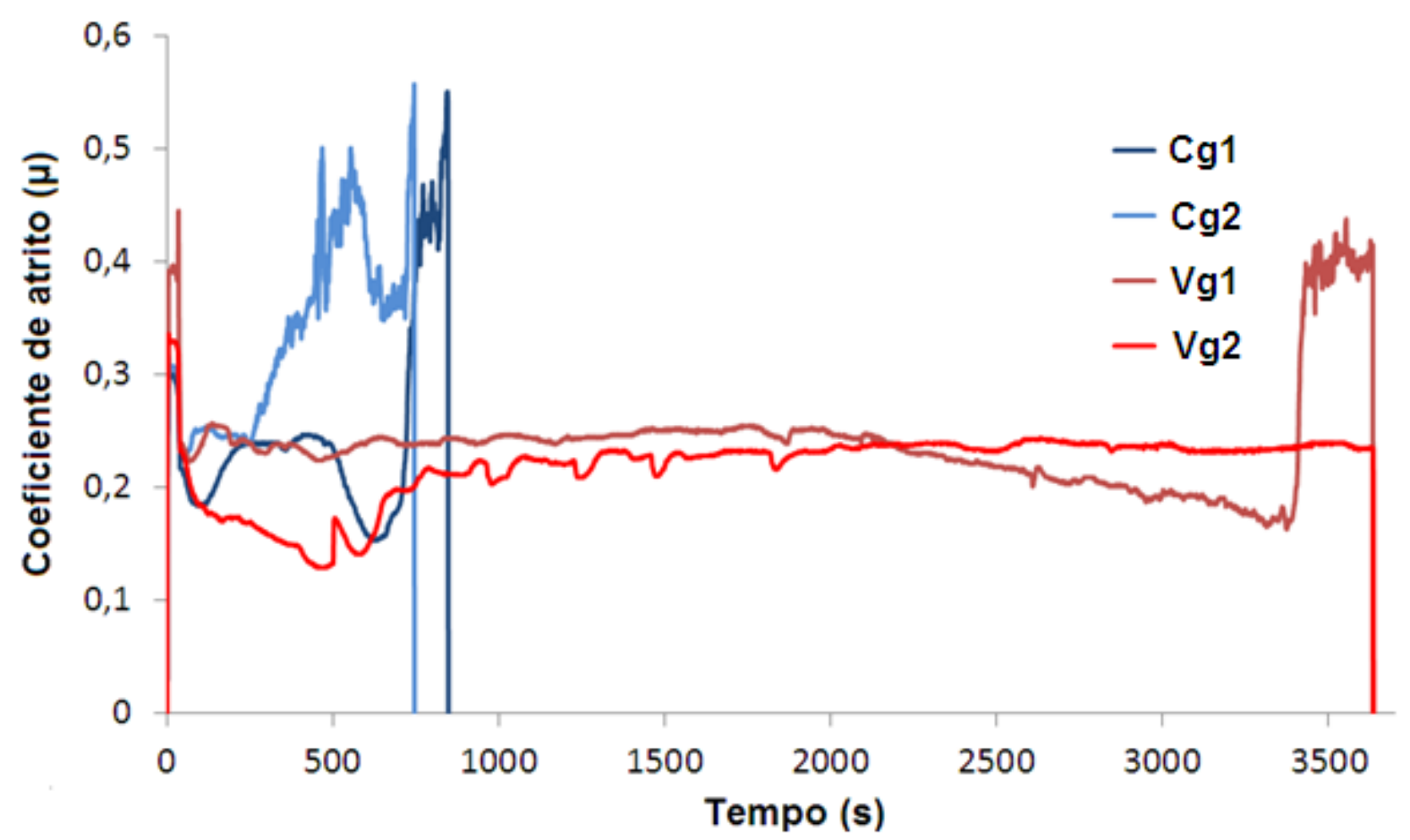

Figura 71 - Coeficiente de atrito registrado pela SRV para as amostras de ferro fundido cinzento (curvas azuis) $\mathrm{Cg} 1 \mathrm{e} \mathrm{Cg} 2 \mathrm{e}$ para as amostras de ferro fundido vermicular (curvas vermelhas) $\mathrm{Vg} 1 \mathrm{e}$ Vg2.

O desempenho do tribossistema com apenas uma gota de óleo é completamente diferente de quando as amostras são testadas completamente submersas em óleo. Enquanto todas as amostras testadas submersas em óleo se estabilizaram em um coeficiente de atrito por volta de 0,07 após cerca de 10 minutos de ensaio, as amostras de ferro fundido vermicular se estabilizaram acima de 0,2 quando testadas com apenas uma gota $e$ as de ferro fundido cinzento nem chegaram a atingir a estabilidade no coeficiente de atrito. As amostras de FC atingiram o coeficiente de atrito limite de 0,5 também por volta de 10 minutos de ensaio. Além disto, a ativação do MoDTC também não ocorreu. Isto mostra que a capacidade do MoDTC promover a queda no coeficiente de atrito está fortemente ligada a quantidade deste aditivo disponível no tribossistema.

\subsubsection{Conclusões parciais}

- Diferentemente dos ensaios realizados com as amostras submersas em óleo, não foi detectado, utilizando a espectroscopia Raman, um filme contínuo e 
bem estabelecido de $\mathrm{MoS}_{2}$. As análises detectaram picos bem definidos relativos a hematita, magnetita e grafita.

- A diferença encontrada nos espectros Raman entre as amostras de FC e FV estava na relação $I_{D} / I_{G}$. As amostras de $F C$ apresentaram o valor de $I_{D} / I_{G}$ de 1,1 enquanto as amostras de FV registraram 1,8 (Vg1) e 1,6 (Vg2). Esta diferença indica que as grafitas dos tribofilmes formados sobre as amostras de FV possuíam maior grau de desordem o que pode acarretar em maior durabilidade.

- As imagens de MEV mostram que houve desgaste adesivo severo nas amostras Cg1, Cg2 e Vg1. Nestas amostras, com 500 vezes de aumento, não foram detectados riscos de brunimento. Já amostra FV-4 apresenta características de uma superfície que passou por um processo de desgaste predominantemente adesivo e moderado. Há também a presença de riscos de brunimento que não foram removidos pelo processo de desgaste. É importante salientar que as crateras encontradas nas superfícies das amostras testadas com apenas uma gota de óleo foram formadas pela ocorrência de desgaste adesivo severo enquanto as que foram encontradas nas superfícies testadas submersas em óleo foram provocadas pelo mecanismo de fadiga de contato.

- As análises de MEV/EDS mostram que as amostras Cg1, Cg2 e Vg1 possuem apenas traços de elementos formadores de tribofilme (P, S, Zn). Isto evidencia que ao final dos ensaios não havia um tribofilme bem constituído nas superfícies destas amostras. A amostra $\mathrm{Vg} 2$ se difere das outras três, pois apresentou as quantidades de 0,6 de $\mathrm{P}, 0,6$ de $\mathrm{S}$ e 0,5 de $\mathrm{Zn}$ em percentual atômico, evidenciando que ainda havia, ao final do ensaio, um tribofilme formado por cadeias de polifosfato de zinco formado a partir do ZDDP. Estas quantidades de P, S e Zn são muito inferiores às registradas nas superfícies das amostras testadas completamente submersas em óleo.

- Os resultados dos tribotestes realizados com apenas uma gota de óleo durante 1 hora mostram mais uma vez a importância do tribofilme formado a partir dos aditivos do óleo. As amostras $\mathrm{Cg} 1, \mathrm{Cg} 2$ e $\mathrm{Vg} 1$ que tiveram uma elevação repentina do coeficiente de atrito antes do final do ensaio apresentavam apenas quantidades residuais de ( $P, S$ e $Z n)$ ao final do 
ensaio. Além disto, não foi detecta a presença de $\mathrm{MoS}_{2}$. A única amostra desta bateria de testes que chegou ao final do ensaio com o coeficiente de atrito estável foi a Vg2 que ainda preservava, ao que tudo indica, um filme de polifosfato de zinco ao final do ensaio.

- As curvas de atrito também justificam a configuração das superfícies obtidas através das análises de MEV e perfilometria ótica. As amostras que apresentaram maior dano, causado por um regime de desgaste adesivo severo, foram as $\mathrm{Cg} 1$ e $\mathrm{Cg} 2$ que atingiram o coeficiente de atrito limite de 0,5 antes dos 10 minutos de ensaios, indicando a ocorrência de scuffing. A amostra Vg1 que apresentou indícios de início de desgaste adesivo severo com uma elevação considerável do seu coeficiente de atrito antes do final do ensaio. Porém, não chegou a atingir o valor de 0,5 estabelecido como limite.

\subsection{Ensaios com apenas uma gota de óleo e interrompidos}

Esta configuração de ensaio foi criada para explicar as diferenças de desempenho entre o FC e o FV nos ensaios realizados com apenas uma gota e 1 hora de duração. Para tanto foram executados ensaios com duração de 5 e 6 minutos. A interrupção do ensaio após 6 min foi determinada porque até este tempo e nestas condições de ensaio o FC e o FV possuem comportamento de coeficiente de atrito similar no triboteste. Portanto, as diferenças identificadas no tribofilme e na morfologia da superfície após este ensaio de 6 minutos podem explicar os eventos que acontecem após este tempo de ensaio decorrido. A adição dos ensaios de 5 minutos teve como objetivo enriquecer as informações acerca da cinética de formação do tribofilme na condição de ensaio de lubrificação com apenas uma gota e avaliar a evolução da morfologia da superfície ao longo do ensaio. As amostras $\mathrm{Ci} 5$ e Vi5 foram submetidas aos ensaios de 5 minutos, enquanto as amostras $\mathrm{Ci} 6 \mathrm{e}$ Vi6 foram usadas nos ensaios de 6 minutos. 


\subsubsection{Microdureza Vickers}

A tabela 26 traz os valores das medições de dureza da superfície das amostras fora da trilha de e desgaste e dentro dela. Como na identificação das amostras dos ensaios anteriores as medições identificadas como superfície são de fora da trilha de desgaste enquanto as identificadas como trilha são de dentro da trilha de desgaste.

Tabela 26 - Microdureza da superfície e da trilha de desgaste das amostras válidas de FV e FC.

\begin{tabular}{|c|c|c|c|c|}
\hline \multirow{4}{*}{ Ci6 } & \multirow[b]{3}{*}{ superficie } & \multicolumn{3}{|c|}{ Dureza Vickers HV 0,1 } \\
\hline & & Média & Desvio & Aumento da dureza (\%) \\
\hline & & 485 & 37 & \\
\hline & trilha & 592 & 39 & 21 \\
\hline \multirow{2}{*}{ Ci5 } & superficie & 493 & 33 & \multirow{2}{*}{4} \\
\hline & trilha & 476 & 20 & \\
\hline \multirow{2}{*}{ Vi6 } & superficie & 553 & 59 & \multirow{2}{*}{-3} \\
\hline & trilha & 538 & 75 & \\
\hline \multirow{2}{*}{ Vi5 } & superficie & 513 & 17 & \multirow{2}{*}{0} \\
\hline & trilha & 513 & 26 & \\
\hline
\end{tabular}

A única amostra que apresentou variação considerável de dureza após o triboteste foi a Ci6 com uma elevação de $21 \%$.

O gráfico da figura 72 traz as medições de dureza dentro da trilha de desgaste. A amostra Ci6 apresenta um valor de dureza estatisticamente maior que as amostras Ci5 e Vi5. Porém, não pode ser considerada diferente da amostra Vi6 porque seus desvios se sobrepõem. 


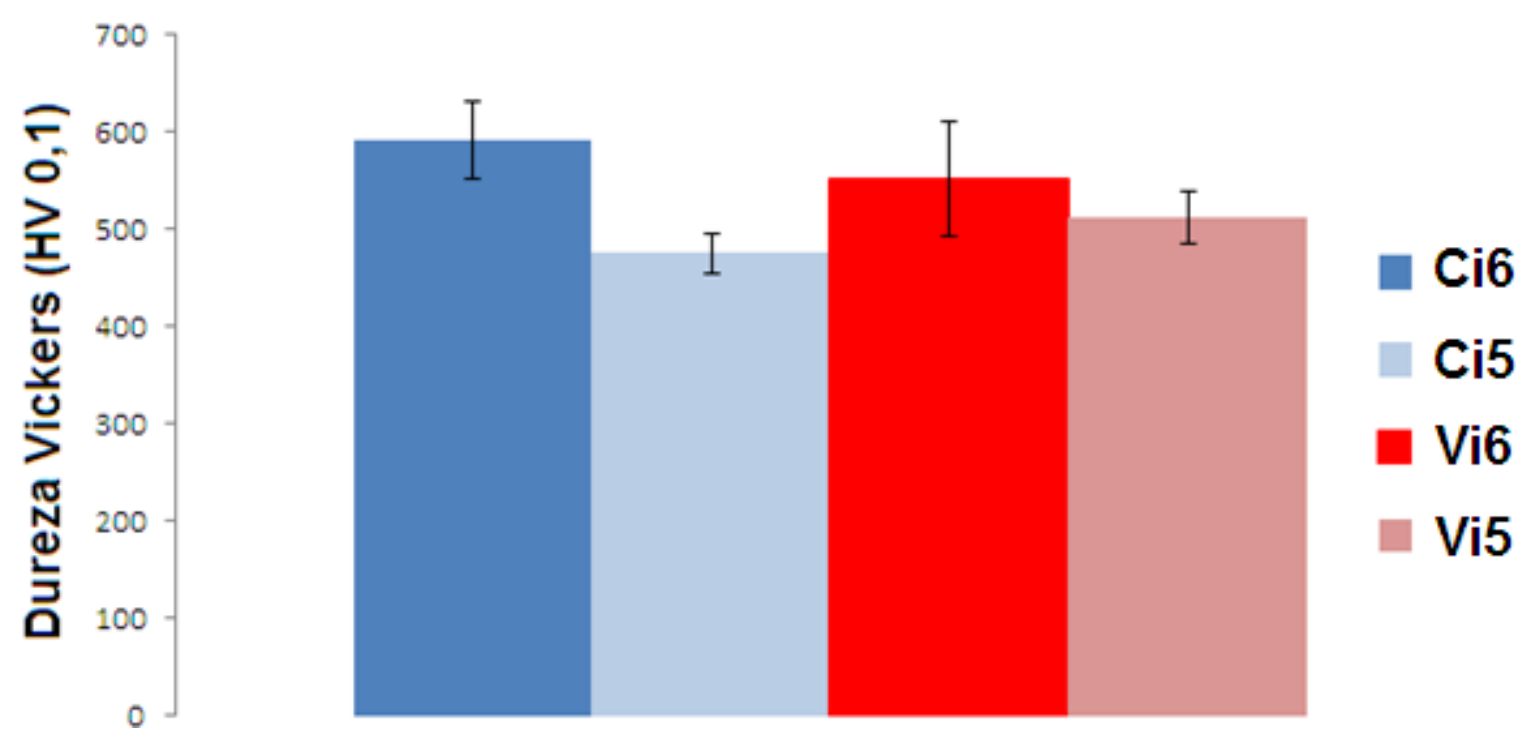

Figura 72 - Dureza da superfície das amostras FC e FV fora da trilha de desgaste.

O gráfico da figura 73 , relativo às medições de dureza antes do triboteste (superfície), mostra que as amostras podem ser consideradas estatisticamente iguais em relação a sua dureza.
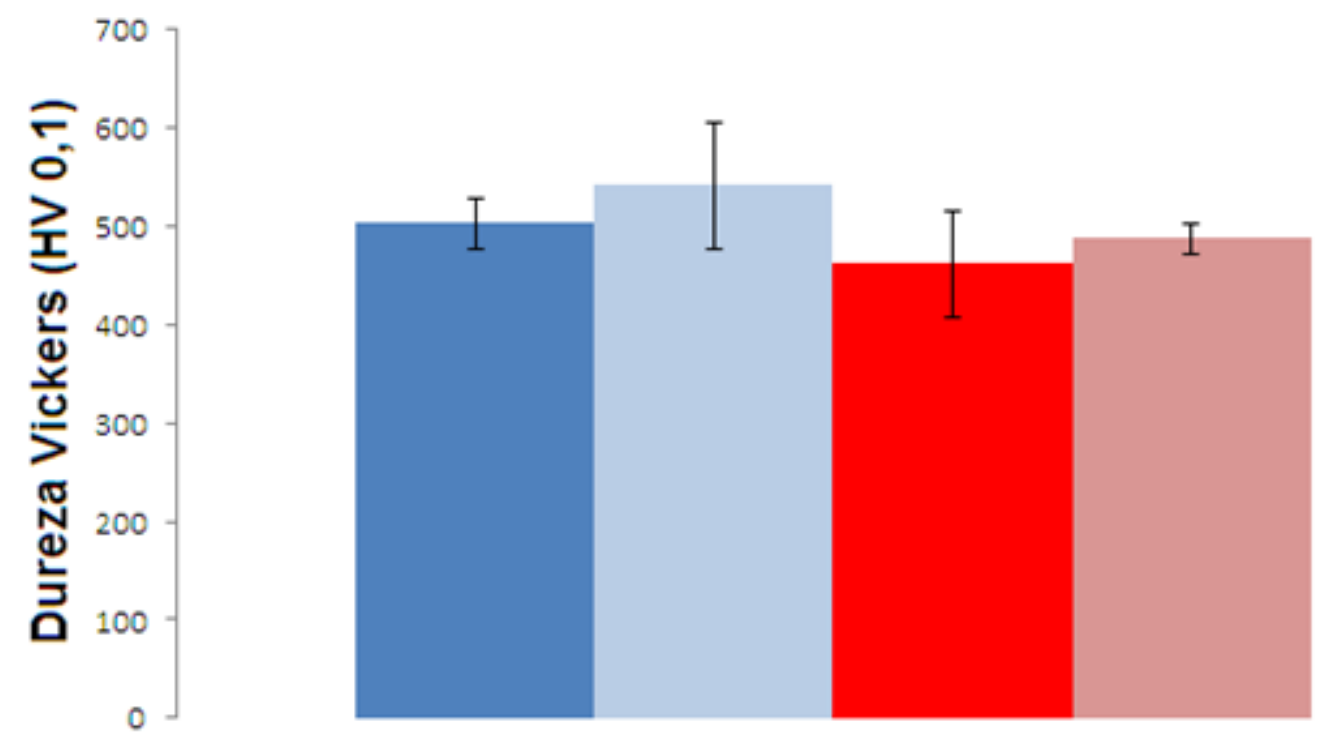

Ci6

Ci5

- Vi6

Vi5

Figura 73 - Dureza da superfície das amostras FC e FV dentro da trilha de desgaste.

\subsubsection{Espectroscopia Raman}

Todas as amostras analisadas antes dos tribotestes com apenas uma gota de óleo e interrompidos apresentaram as mesmas características: Um espectro característico 
da grafita nas regiões de fenda e um espectro sem picos definidos nas regiões de platô, o que indica uma superfície metálica com pouca ou nenhuma oxidação. Os espectros de todas as amostras analisadas se encontram na figura 74 (fenda) e 75 (platô).

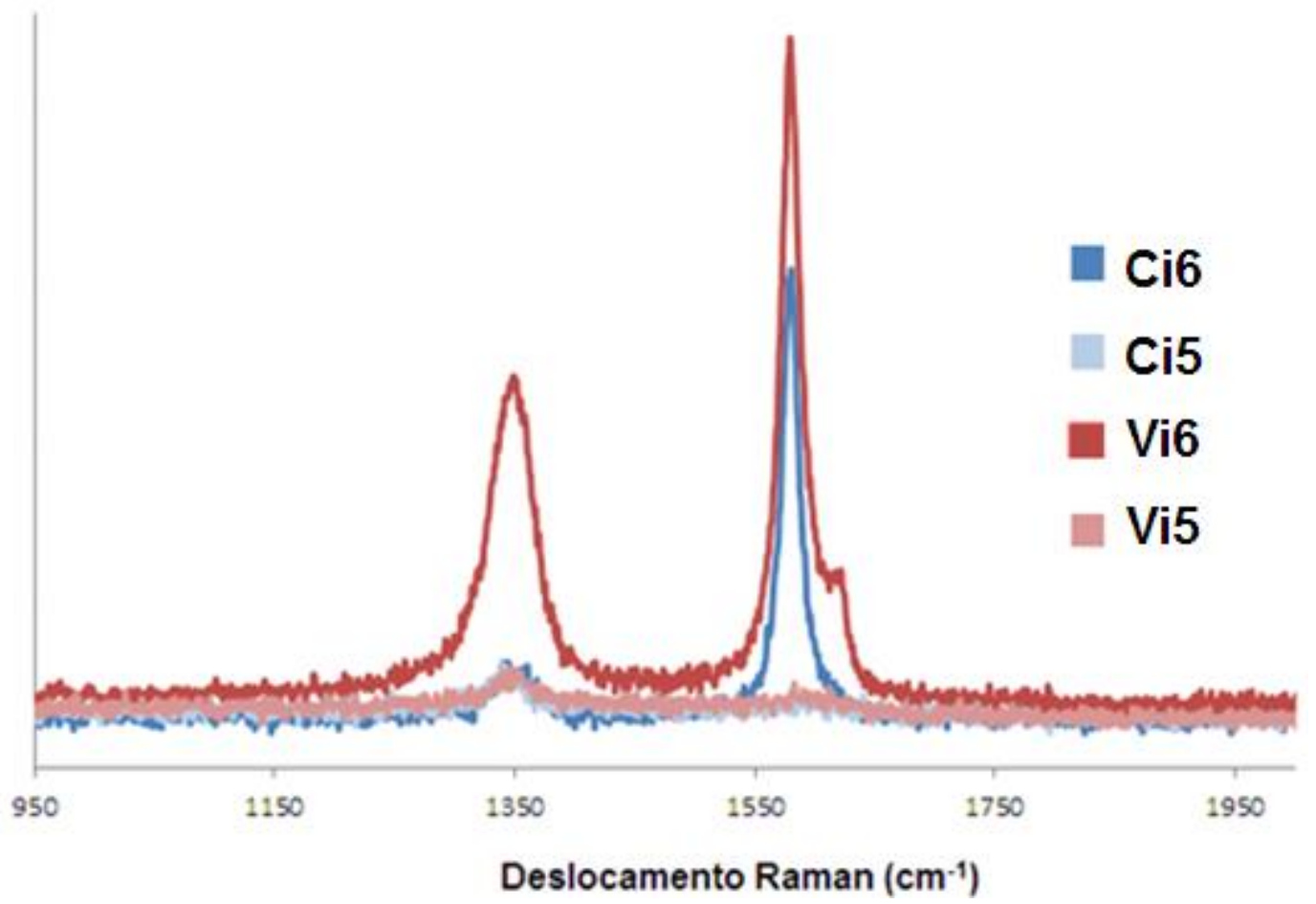

Figura 74 - Espectros Raman registrados nas fendas das amostras de FC (tons de azul) e FV (tons de vermelho). 


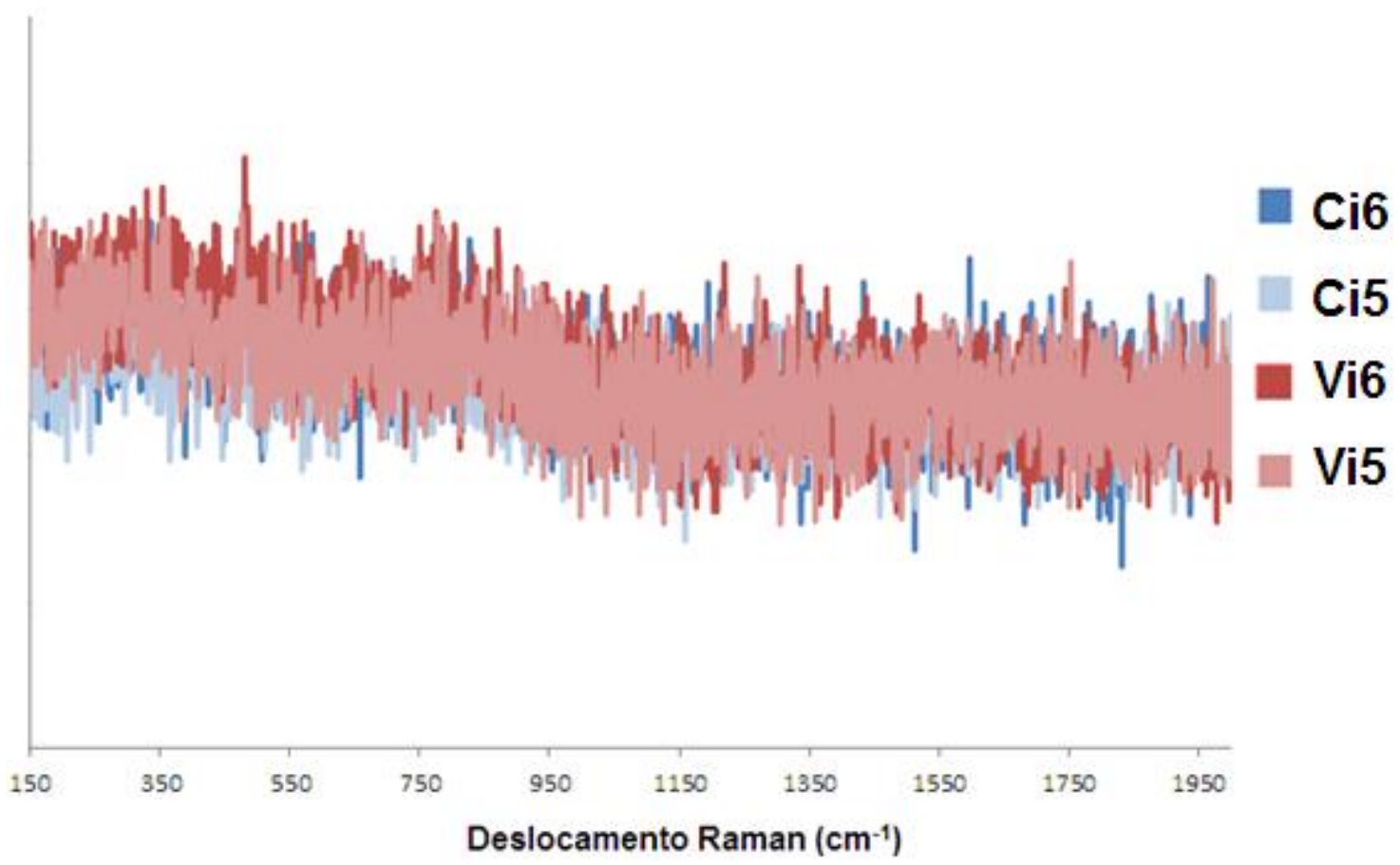

Figura 75 - Espectros Raman registrados nos platôs das amostras de FC (tons de azul) e FV (tons de vermelho).

Para as amostras testadas até 5 min de duração de ensaio os espectros colhidos dentro das trilhas de desgaste (figura 76) também não mostraram diferenças significativas entre as amostras de FV e FC. Todas as amostras apresentaram espectros semelhantes que combinam picos relativos a presença de hematita (219, 286 e 407), magnetita (654) e grafita (1339 e 1605). Estes espectros são muito semelhantes aos colhidos dentro da trilha de desgaste das amostras testadas com apenas uma gota óleo com 1 hora de duração. A diferença importante está no valor de $I_{D} / l_{G}$ para cada amostra. Enquanto nas amostras testadas por 1 hora a diferença da relação $I_{D} / I_{G}$ entre as amostras de cinzento e vermicular era clara, nas amostras testadas por 5 minutos esta diferença se torna sutil. $O$ valor de $I_{D} / l_{G}$ para a amostra Vi5 é de 1,65 e para a amostra Ci5 é de 1,42. 


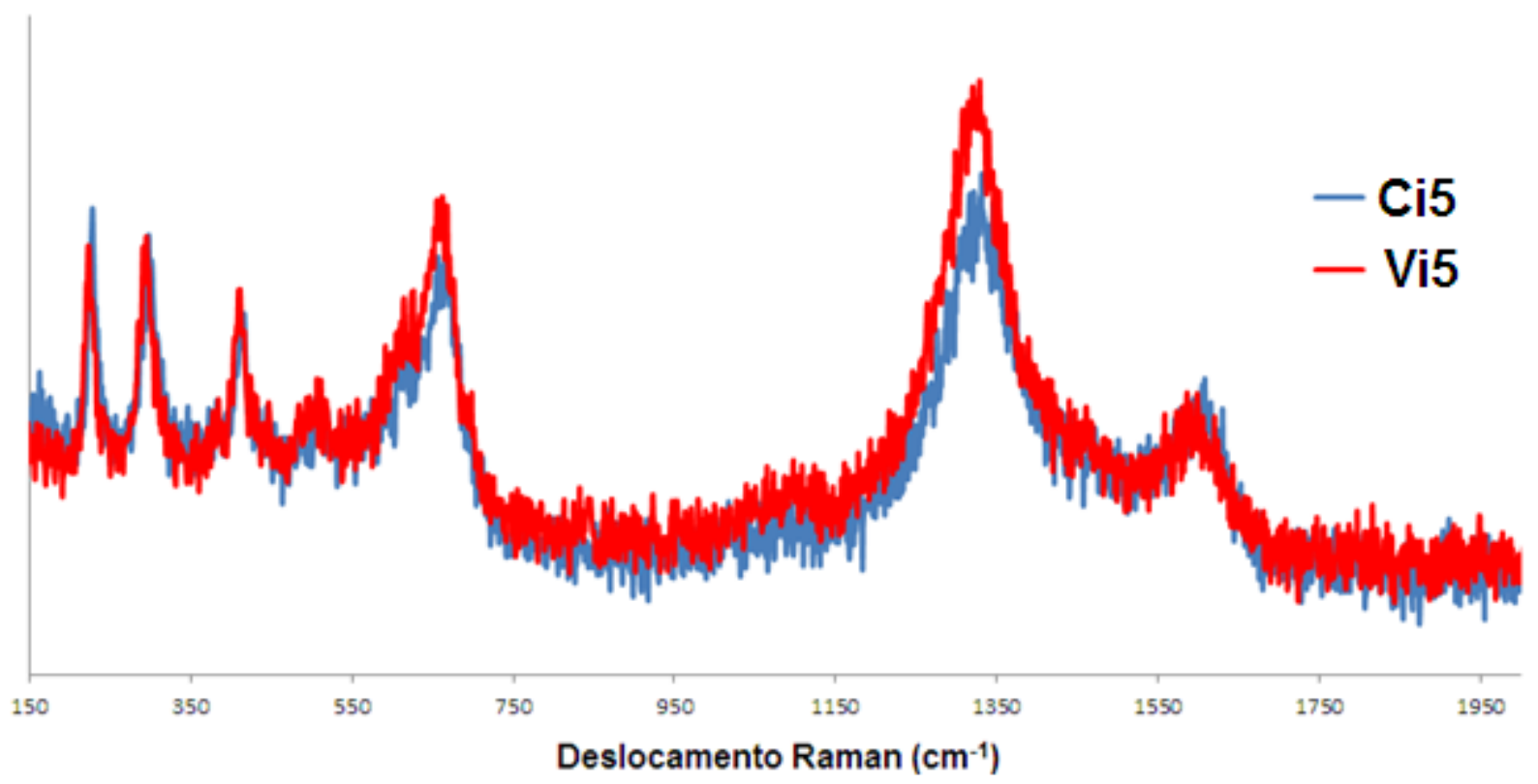

Figura 76 - Espectros registrados dentro da trilha de desgaste das amostras de FC (azul) e FV (vermelho) dos ensaios interrompidos com 5 minutos.

Nas amostras testadas por 6 minutos foram detectadas diferenças em relação aos compostos encontrados nas amostras testadas por 5 minutos, o que demonstra uma evolução na formação do tribofilme. Além disto, também foram encontradas diferenças entre as amostras de FC e FV. A primeira diferença relativa ao tempo de ensaio foi que nas amostras testadas por 5 minutos os compostos detectados tanto nas amostras de FC como de FV foram hematita e magnetita por toda a trilha de desgaste. Já nas amostras testadas por 6 minutos o composto predominante encontrado via espectroscopia Raman na superfície da trilha de desgaste de ambos os tipos de amostras (FC e FV) foi o $\mathrm{MoS}_{2}$. Além dele, foram encontradas pequenas áreas de metal exposto. A diferença detectada entre as amostras de FC e FV foi que na primeira foram encontradas pequenas áreas avermelhadas com um espectro compatível com a hematita. Na segunda ao invés das áreas avermelhadas foram encontradas áreas com uma coloração cinza azulada onde foram registrados espectros de uma combinação de $\mathrm{MoS}_{2}$ com grafita. Os espectros das amostras testadas por 6 minutos estão representados na figura 77. As imagens das superfícies com as indicações de onde foram registrados os espectros estão na figura 78 . 

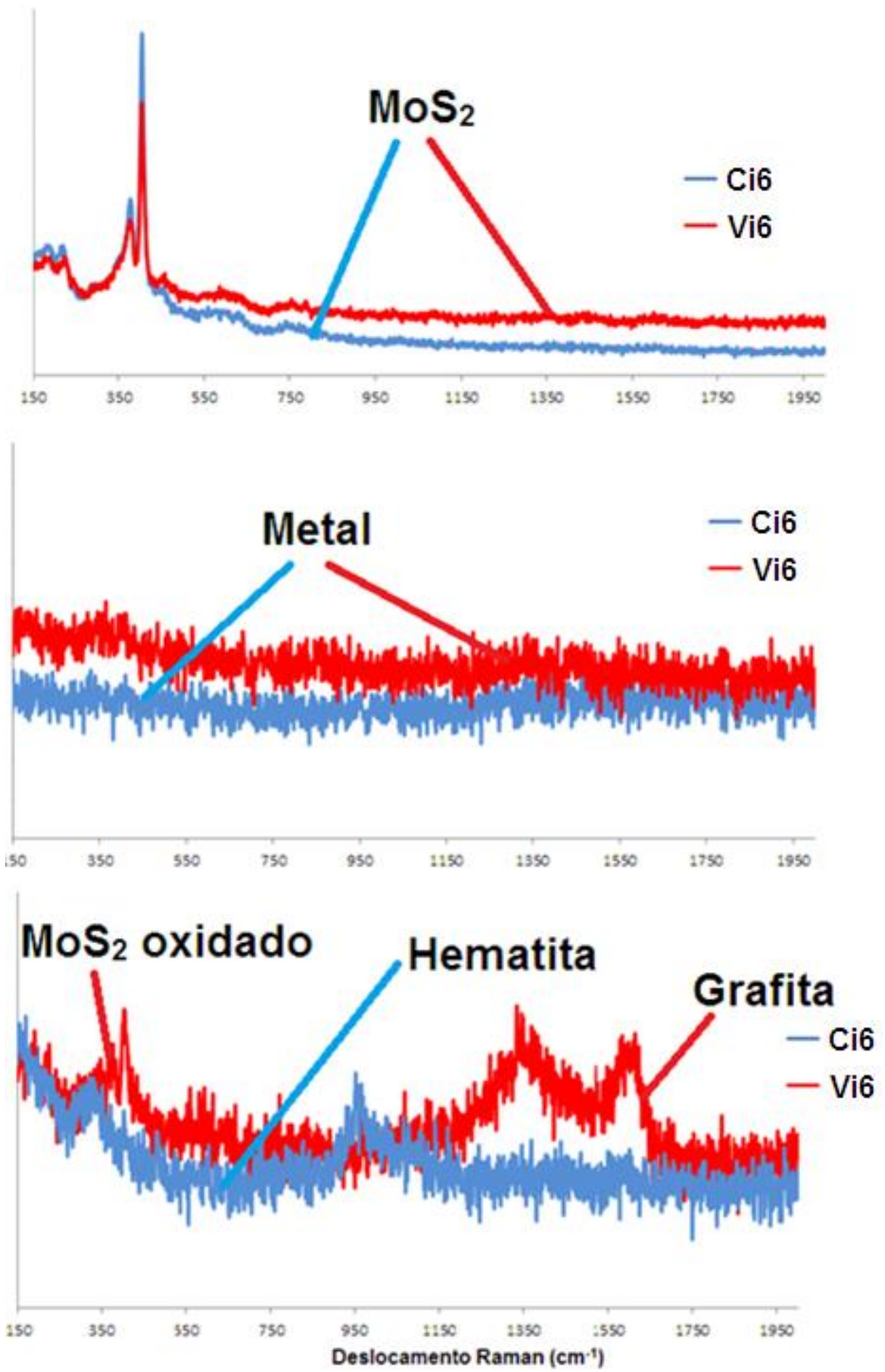

Figura 77 - Espectros registrados nas trilhas de desgaste das amostras de FC e FV testadas por 6 minutos com apenas uma gota de óleo. 

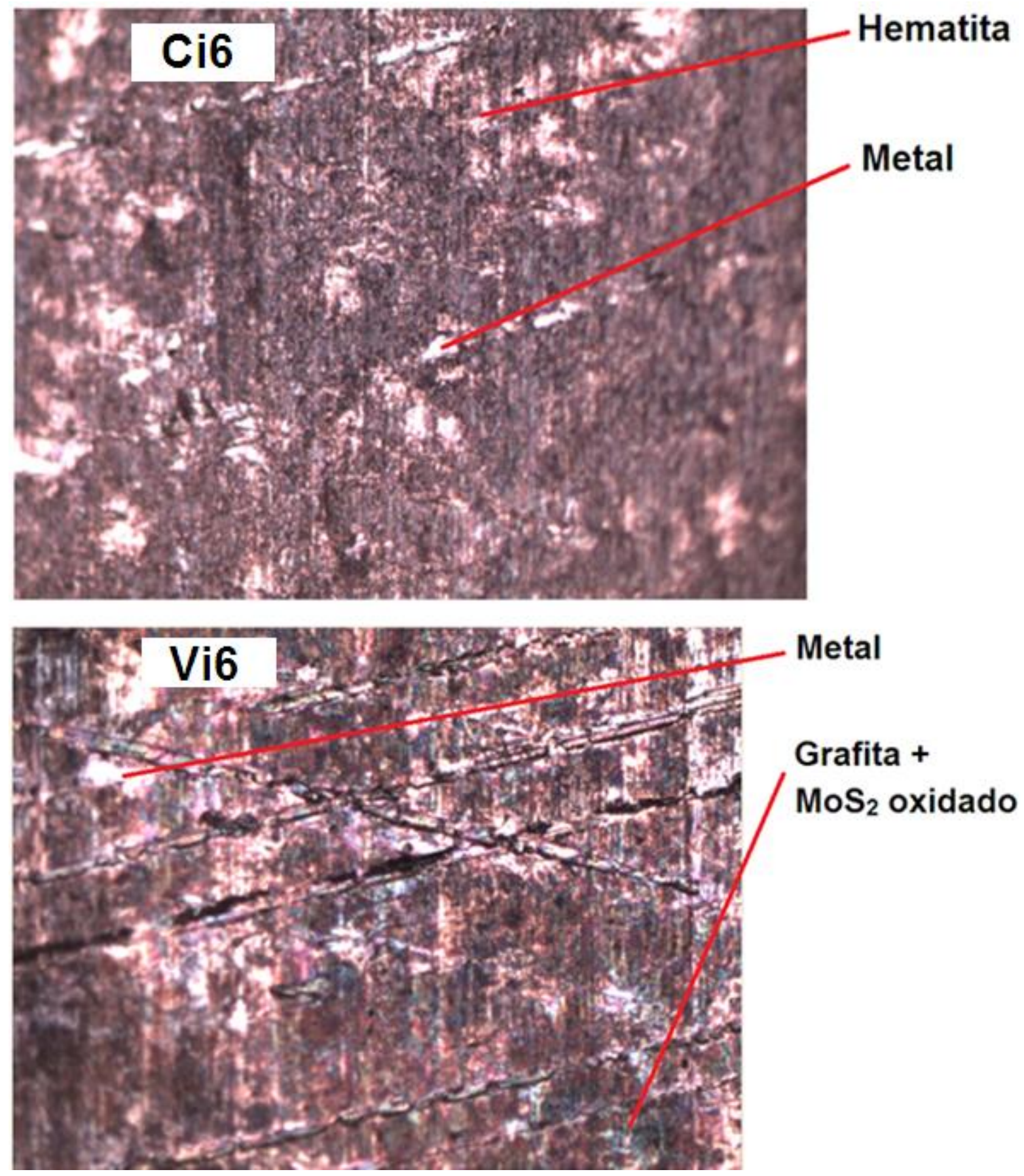

Figura 78 - Regiões onde foram registrados os espectros das amostras de FC e FV testadas com apenas uma gota de óleo por 6 minutos.

\subsubsection{Microscopia eletrônica de varredura}

A Figura 79 traz as imagens de MEV com 500X de aumento das superfícies das amostras antes dos tribotestes. Não há diferença morfológica aparente entre as amostras de FC e FV. Elas também são semelhantes às superfícies das amostras 
usadas nos testes com as amostras imersas em óleo e com as amostras testadas com apenas uma gota de óleo durante por 1 hora.
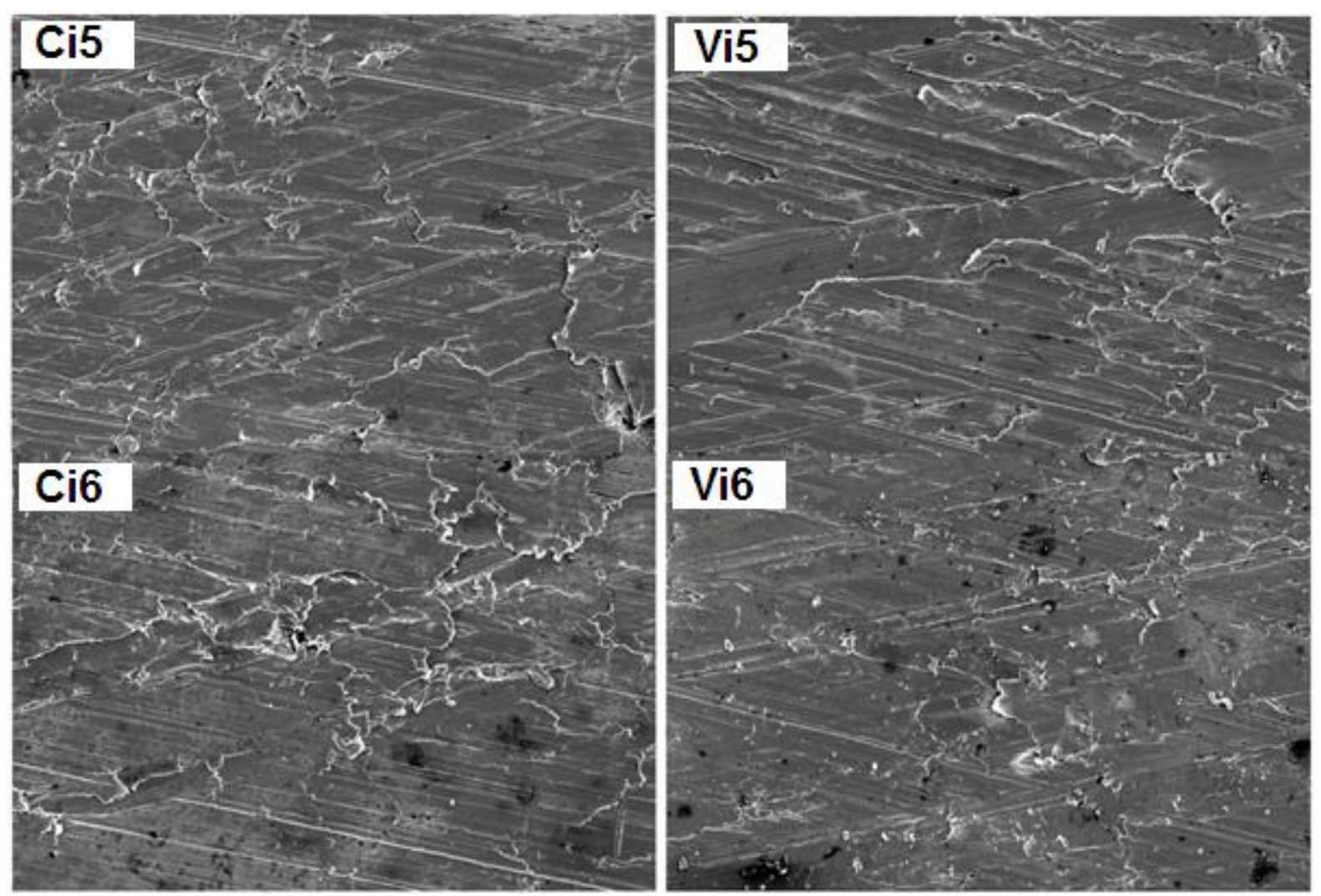

Figura 79 - Superfícies das amostras FC (à esquerda) e FV (à direita) antes dos tribotestes.

A tabela 27 traz os percentuais atômicos do carbono e do oxigênio obtidos através da análise de EDS das superfícies das amostras antes dos tribotestes. Os outros elementos formadores de tribofilme como zinco, fósforo e enxofre foram detectados em quantidades residuais (entre 0 e 0,1 ). 
Tabela 27 - Quantidades de carbono e oxigênio nas superfícies das amostras antes dos tribotestes.

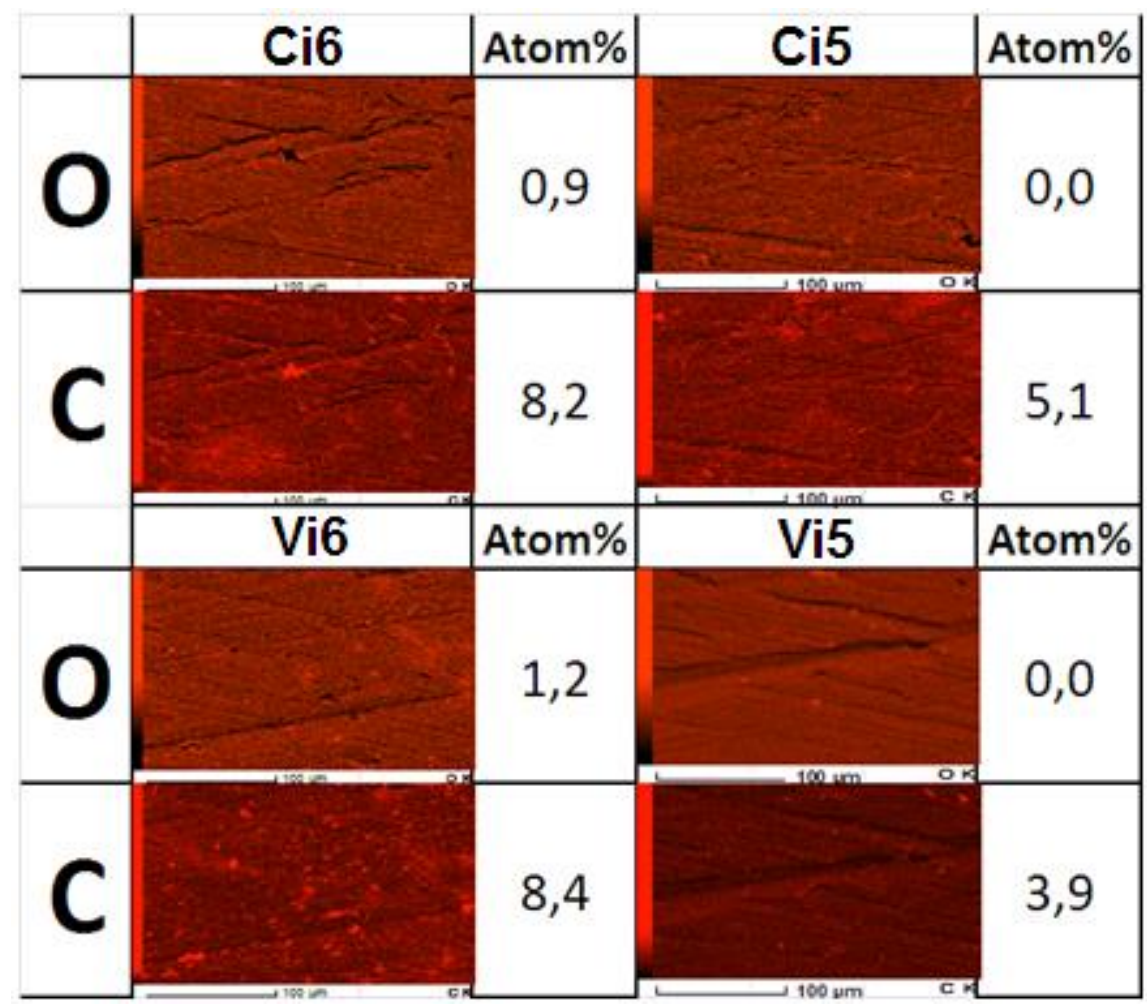

As imagens de MEV registradas após os ensaios dentro da trilha de desgaste, figura 80, mostram superfícies bastante deformadas plasticamente. Na amostra de FC (Ci5) (acima) os riscos de brunimento dos platôs foram eliminados e os riscos mais profundos que delimitam os platôs foram preenchidos com algo que parece ser resíduo de desgaste. Há também manchas escuras na superfície e não foram detectados veios de grafita abertos à superfície.

A amostra de FV (Vi5), (abaixo na figura 80), também não apresenta mais riscos de brunimento sobre os platôs. Os riscos mais profundos que delimitam os platôs não estão tão recobertos por resíduos de desgaste quanto a amostra de FC. As manchas escuras também estão em menor quantidade e possuem uma textura superficial diferente. Existem veios de grafita aflorando a superfície em uma quantidade significativa. 


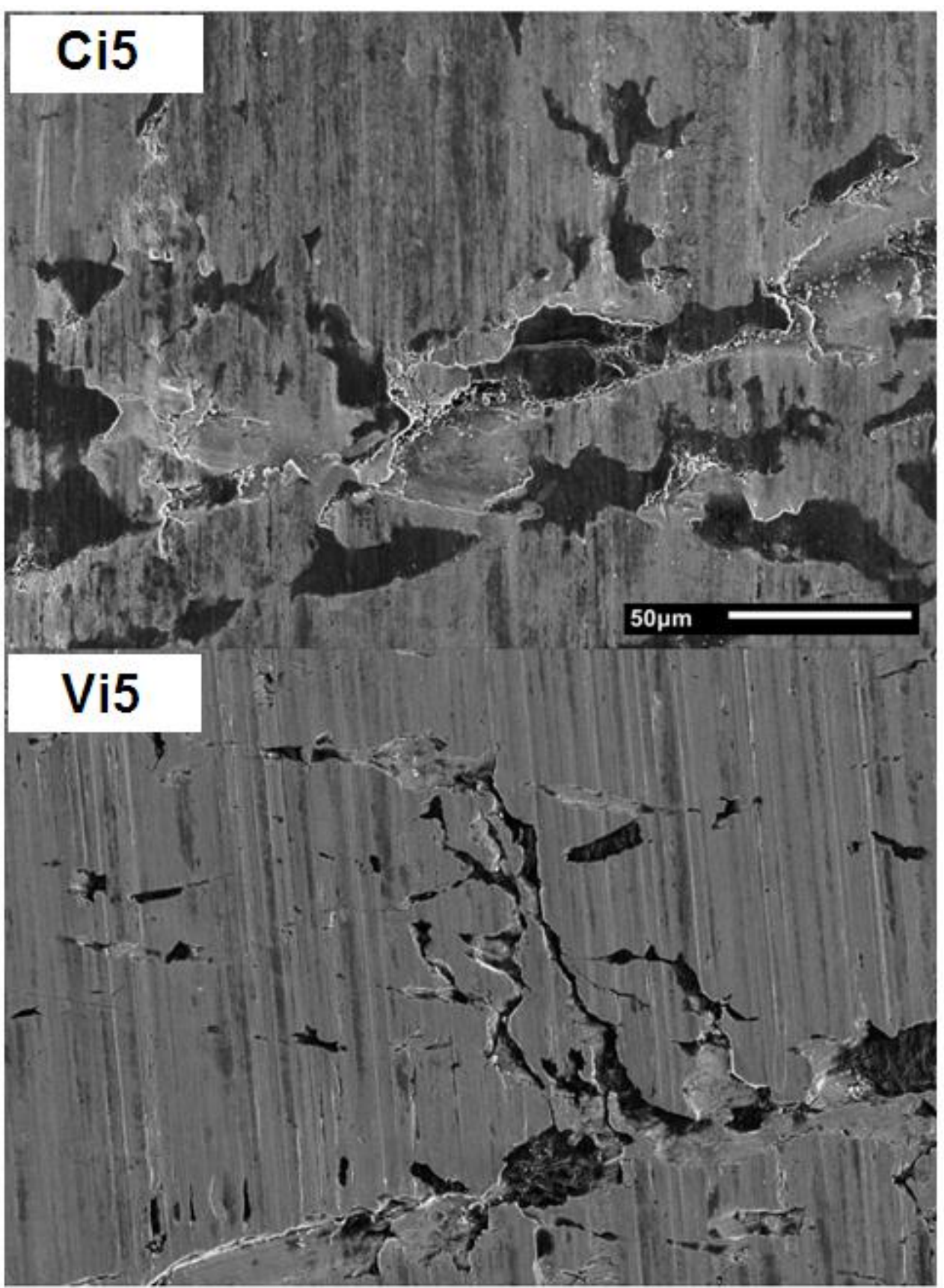

Figura 80 - Superfícies das trilhas de desgaste das amostras de FC (acima) e da amostra de FV (abaixo) que foram submetidas ao ensaio com duração de 5 minutos.

A tabela 28 traz os mapas de EDS das trilhas de desgaste das amostras de FC e FV testadas por 5 minutos no triboteste. As diferenças de composição química e de distribuição dos elementos nas superfícies são as que seguem:

$>\mathrm{A}$ amostra de FC possui uma quantidade de $\mathrm{O}$ consideravelmente maior na sua superfície que a amostra de FV. Grande parte deste oxigênio está concentrada nas regiões das manchas escuras identificadas nas fotos de MEV da figura 80 . 
> A amostra de FC também possui maior quantidade de $\mathrm{P}, \mathrm{S}$ e $\mathrm{Zn}$. Isto indica que o tribofilme formado a partir do ZDDP está mais bem constituído na amostra de FC do que na de FV aos 5 minutos de ensaio.

> O C na amostra de FC também está em maior quantidade e mais espalhado pela superfície. Uma boa parte está acumulada nos riscos de brunimento mais profundos, onde aparecem as regiões com manchas escuras identificadas na figura 80. No FV o C está mais concentrado nas fendas que dão acesso às grafitas para a superfície. Esta diferença de distribuição do $C$ na superfície das amostras indica que para o FC com 5 minutos de ensaio as grafitas já haviam sido, na sua maioria, estrudadas para a superfície e que as fendas de acesso a superfície já haviam sido fechadas. Na amostra de FV o $\mathrm{C}$ ainda se concentrava nas fendas que preservavam acesso à superfície, indicando que o material ainda possuía capacidade de fornecer grafita para a superfície. 
Tabela 28 - Quantidades dos elementos formadores de tribofilme e a sua distribuição em uma região da trilha de desgaste, obtidas através de mapas de EDS para as amostras de FC e FV após o triboteste de 5 minutos de duração.

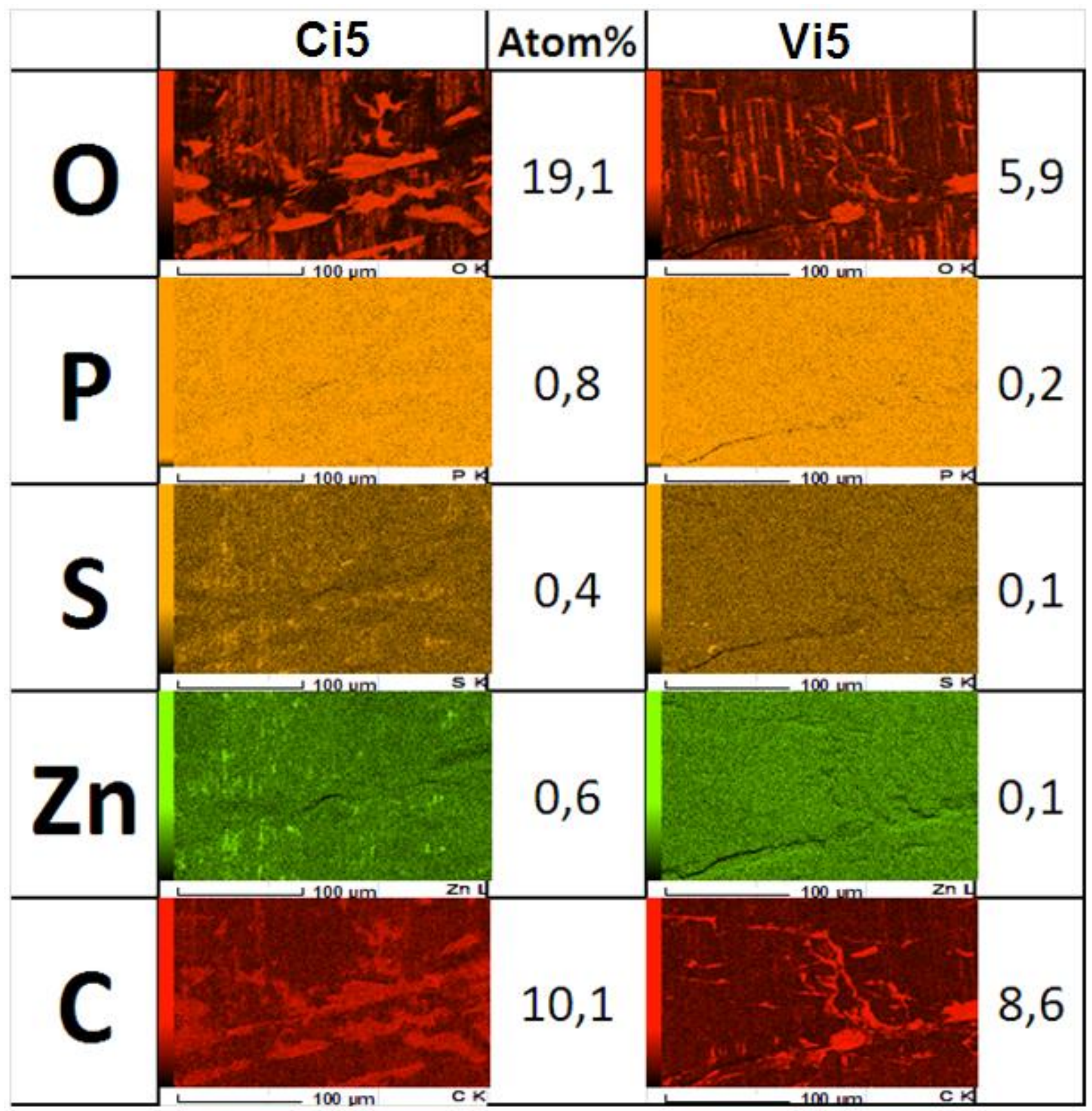

A figura 81 traz as imagens de MEV registradas nas superfícies das amostras de FC e FV que foram testadas por 6 minutos de triboteste. A amostra Ci6 (acima na imagem) apresentou uma superfície bastante deformada plasticamente onde não é possível identificar riscos de brunimento remanescentes nem fendas de grafita abertas a superfície. Na amostra de Vi6 (foto abaixo da figura 81) alguns riscos de brunimento mais profundos que delimitam os platôs ainda podem ser observados. A superfície desta amostra também apresenta elevado grau de deformação plástica da sua superfície. 


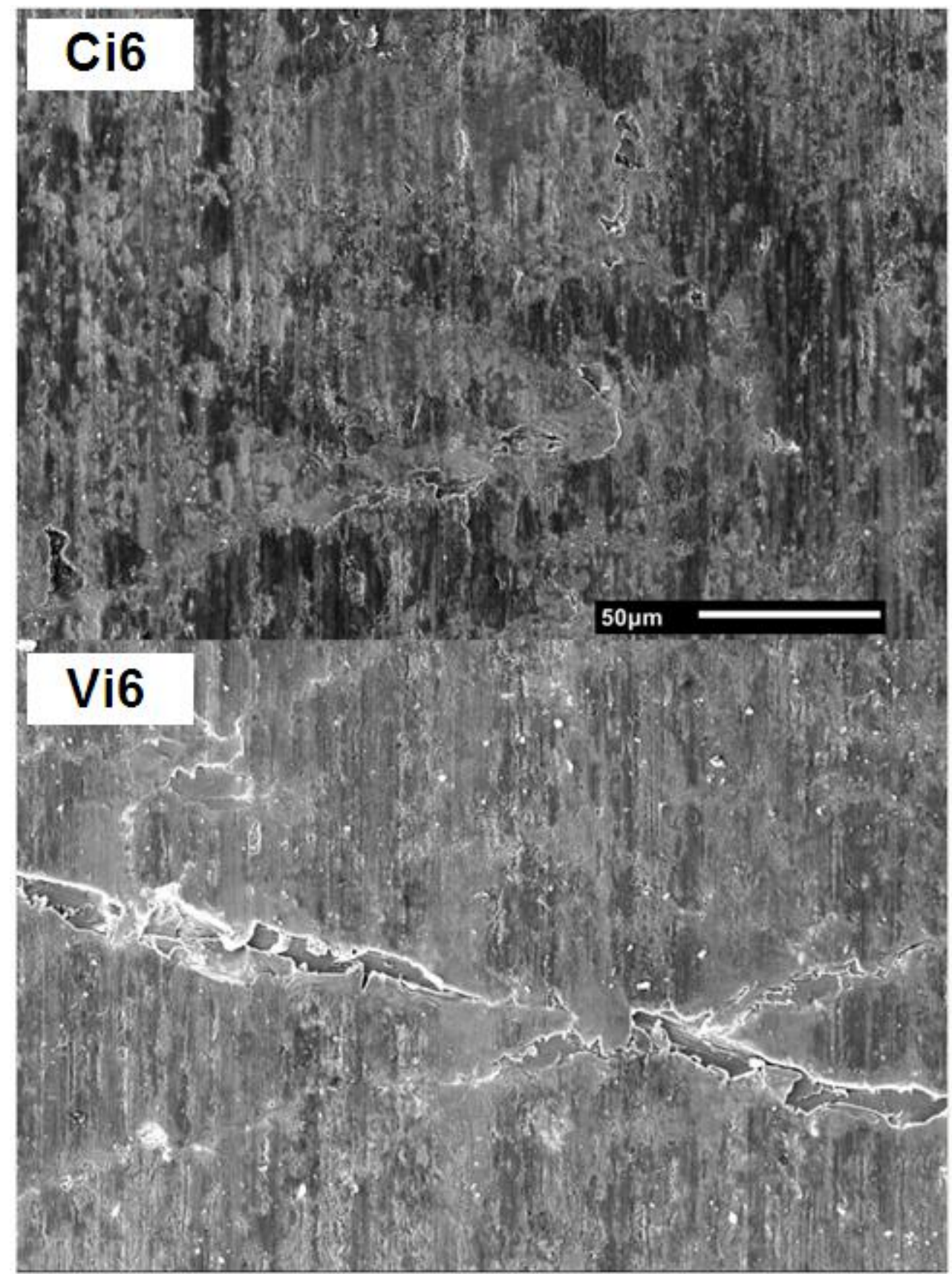

Figura 81 - Superfícies das amostras de FC (à esquerda) e FV (à direita) dentro da trilha de desgaste após o triboteste.

Os mapas de EDS das superfícies de desgaste das amostras após o triboteste de 6 minutos são apresentados na tabela 29. Nesta tabela também são apresentados os percentuais atômicos dos elementos formadores de tribofilme (O, P, S, Zn e C). Os mapas mostram que após 6 minutos o tribofilme já está bem estabelecido e distribuído pela superfície para ambos os tipos de ferros fundidos avaliados. A diferença que pode ser observadas através dos mapas é que para a amostra de FC há algumas regiões de "sombra" que indicam que parte do tribofilme foi removido. A 
análise dos percentuais atômicos mostra que não há diferenças significativas para os elementos $\mathrm{O}, \mathrm{P}, \mathrm{S}$ e $\mathrm{Zn}$. Já para o $\mathrm{C}$ a quantidade registrada na superfície da amostra de FC é bastante inferior à registrada na amostra de FV. Esta diferença de quantidade de $\mathrm{C}$ e as regiões de "sombra" nos mapas de EDS indicam que o tribofilme, tanto o formado a partir da grafita quanto o que se forma a partir do ZDDP, já entrou em um estágio de remoção, deixando a superfície mais exposta ao desgaste do que a amostra de FV para o mesmo tempo de ensaio.

Tabela 29 - Quantidades dos elementos formadores de tribofilme e a sua distribuição em uma região da trilha de desgaste, obtidas através de mapas de EDS para as amostras de FC e FV após o triboteste de 6 minutos de duração.

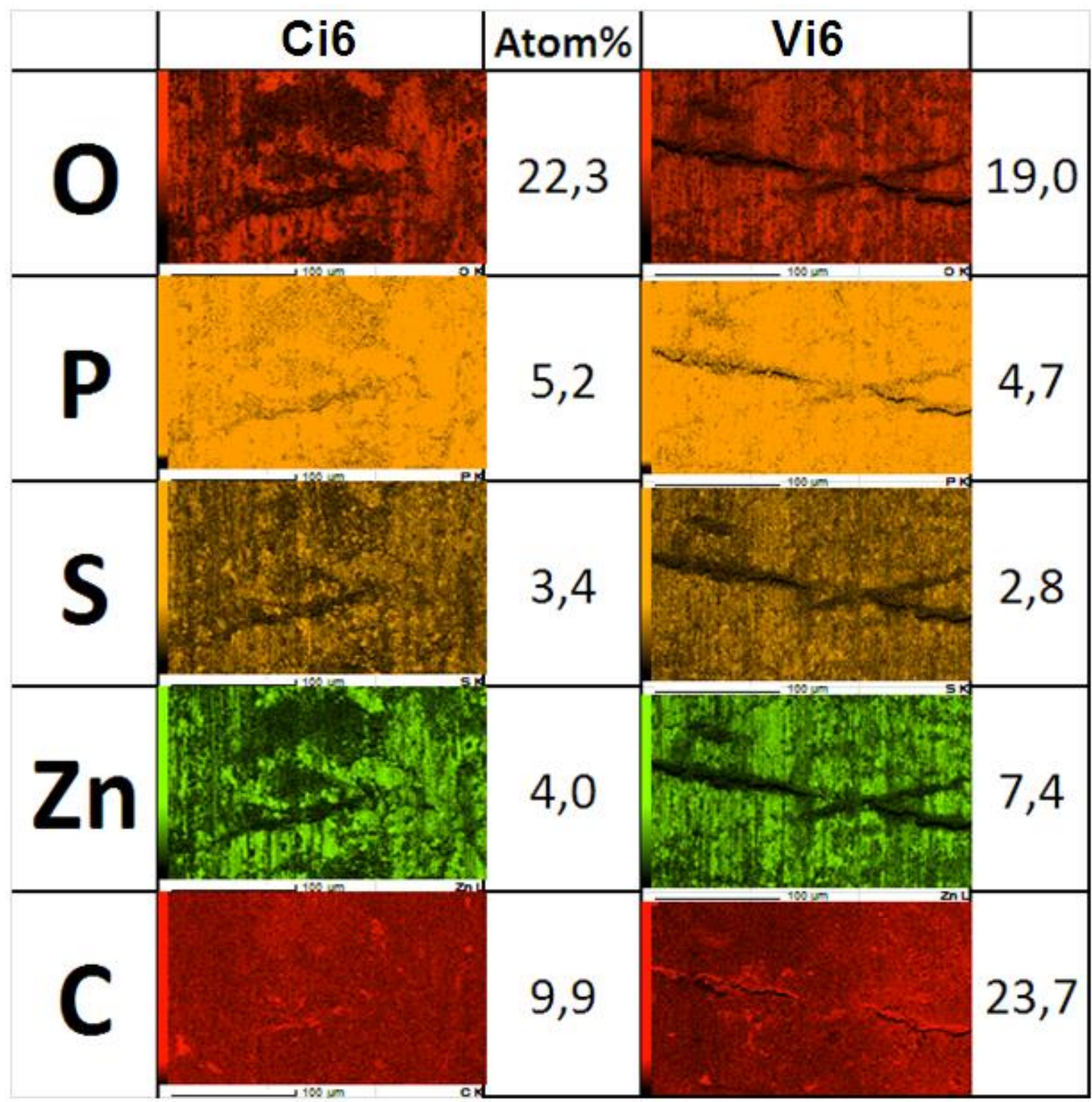




\subsubsection{Perfilometria ótica}

As imagens de perfilometria ótica (figura 82) das amostras do triboteste de 5 minutos reforçam o que já havia sido constatado através das imagens de MEV da trilha de desgaste (figura 80). A amostra de FC não apresenta mais riscos de brunimento na trilha de desgaste após o ensaio. Já a amostra de FV ainda conserva alguns dos seus riscos de brunimento mais profundos.
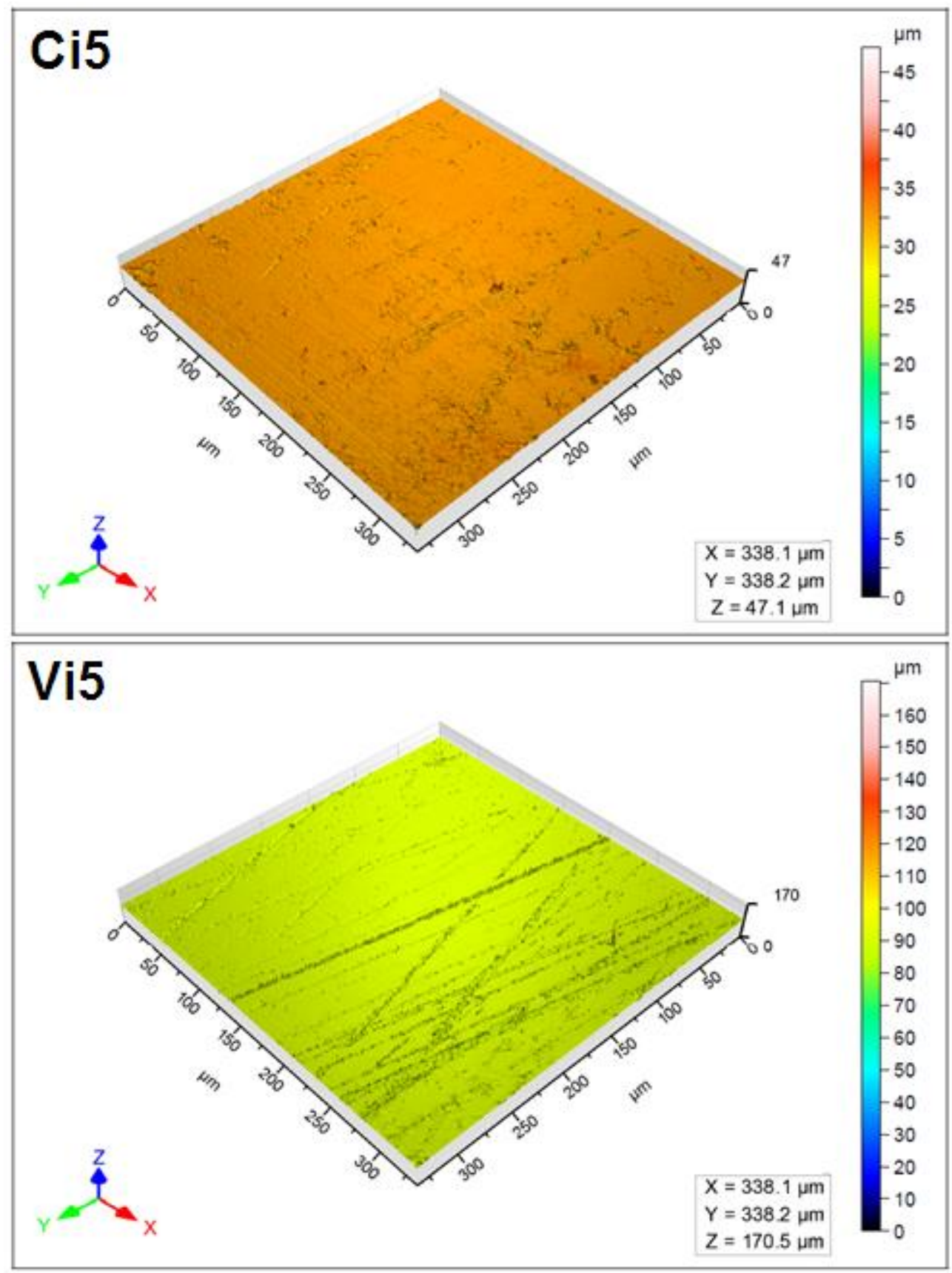

Figura 82 - Imagens do centro da trilha de desgaste da amostra de FC (acima) e FV (abaixo) geradas por interferometria ótica. 
A figura 83 traz as imagens de interferometria ótica das amostras de FC (acima na imagem) e FV (abaixo), após o triboteste de 6 minutos de duração. A amostra de FC apresenta alguns riscos de brunimento remanescentes e crateras que indicam início de desgaste adesivo severo. A amostra de FV tem uma maior quantidade de riscos de brunimento remanescentes. Além disto, é possível observar alguns picos de rugosidade que não foram removidos pelo processo de desgaste.

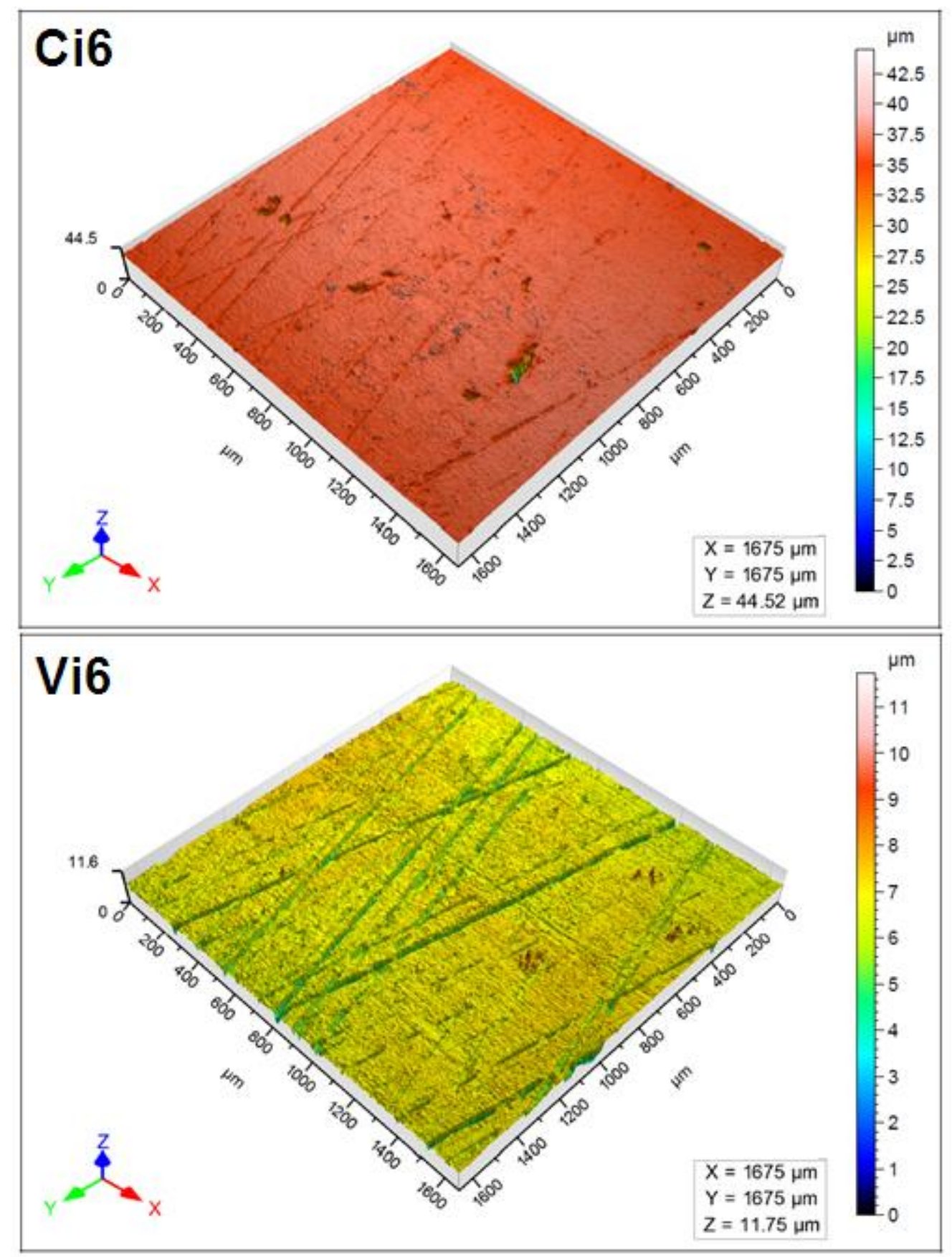

Figura 83 - Imagens do centro da trilha de desgaste das amostras de FC (acima) e FV (abaixo) geradas por interferometria ótica. 


\subsubsection{Triboteste}

O gráfico da figura 84 mostra a curva de coeficiente de atrito dos ensaios de 5 minutos. A grande diferença entre as curvas da amostra de FC (azul) e FV (vermelho) está no comportamento do coeficiente de atrito próximo ao final do ensaio. Para a amostra de FC há uma elevação abrupta do coeficiente de atrito que indica o início do processo de desgaste adesivo severo. Para amostra de FV o coeficiente de atrito permanece praticamente estável até o final do ensaio.

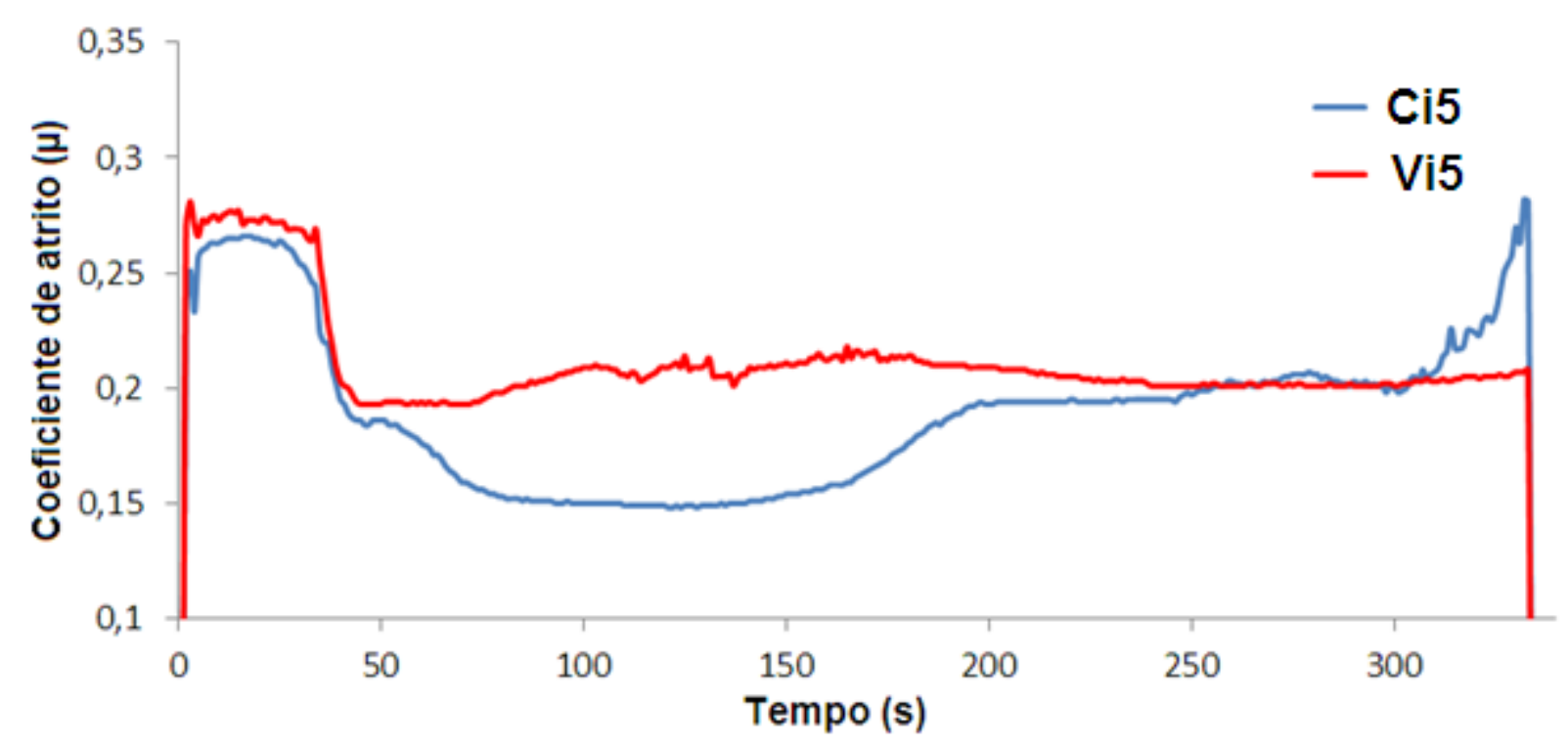

Figura 84 - Coeficiente de atrito registrado pela SRV para a amostra de ferro fundido cinzento (curva azul) Ci5 e para a amostra de ferro fundido vermicular (curva vermelha) Vi5.

As curvas de atrito dos ensaios de 6 minutos são apresentadas no gráfico da figura 85. Neste ensaio não foram detectadas diferenças importantes entre 0 comportamento do coeficiente de atrito da amostra de FC (azul) e do coeficiente de atrito da amostra de FV (vermelho). 


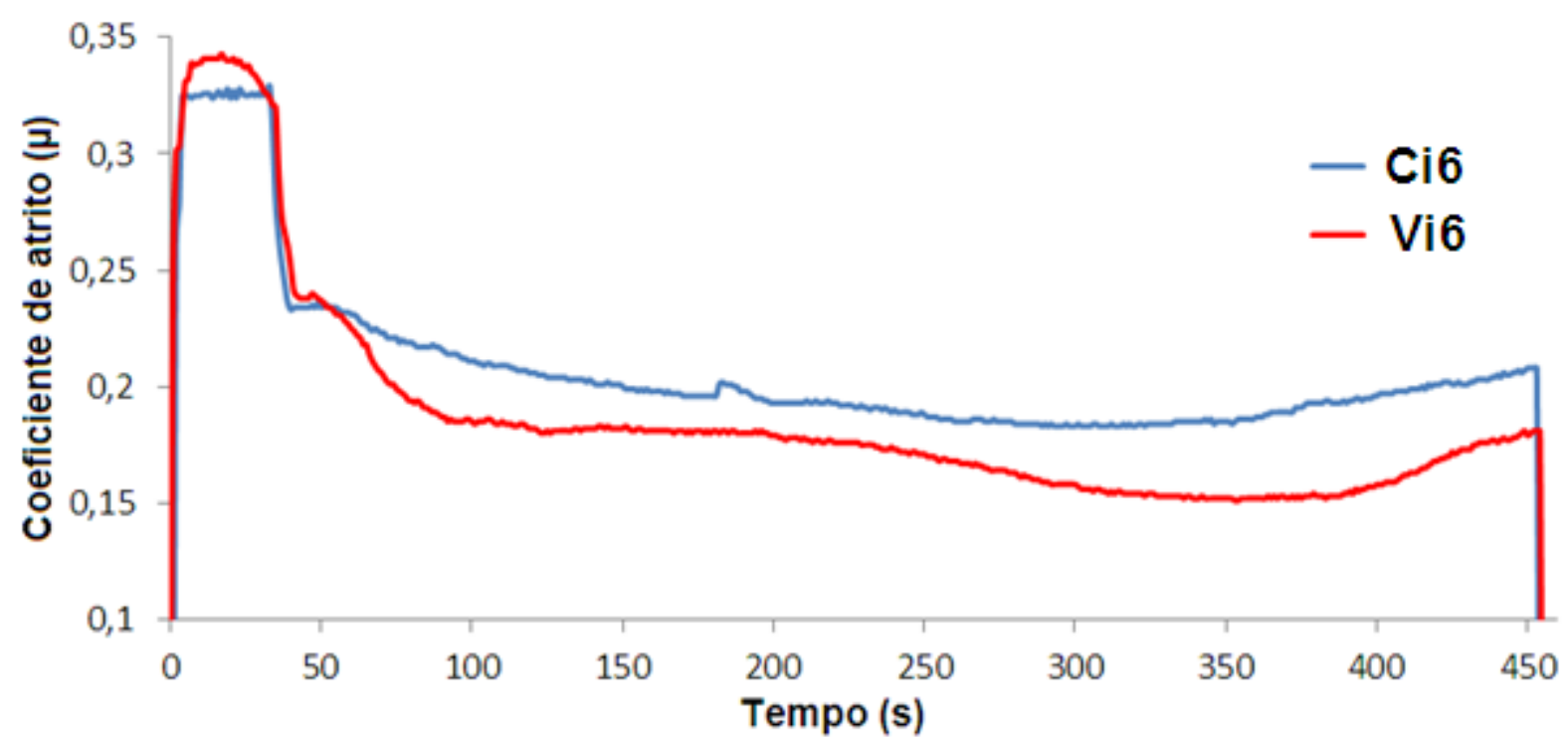

Figura 85 - Coeficiente de atrito registrado pela SRV para a amostra de ferro fundido cinzento (curva azul) Ci6 e para as amostras de ferro fundido vermicular (curva vermelha) Vi6.

Os ensaios interrompidos foram bem sucedidos em esclarecer como o tribossistema evolui quando a lubrificação acontece com apenas uma gota de óleo. Nesta condição de lubrificação o formato da grafita (lamelar ou vermicular) tem grande importância na maneira como o degaste evolui e consequentemente na durabilidade da amostra no triboteste.

\subsubsection{Conclusões parciais}

- O tribofilme de $\mathrm{MoS}_{2}$, formado a partir do MoDTC foi detectado nas superfícies das amostras de ambos os tipos de ferro fundido (cinzento e vermicular) após os tribotestes de 6 minutos. Nas superfícies das amostras testadas por 5 minutos o $\mathrm{MoS}_{2}$ não foi detectado. Isto indica que a menor oferta de óleo influencia no tempo de ativação do MoDTC já que nos testes efetuados com a amostra completamente submersa em óleo todas as amostras já haviam passado pela ativação do MoDTC após 5 minutos de ensaio.

- O filme de $\mathrm{MoS}_{2}$ encontrado nas amostras testadas por 6 minutos no triboteste, diferentemente do que ocorreu nas amostras testadas submersas em óleo, não cobria toda a trilha de desgaste. Isto mostra que para que ocorra a queda brusca no coeficiente de atrito, característica da atuação do 
MoDTC, é necessária uma área de cobertura mínima da área que está sendo submetida ao desgaste.

- Nas superfícies das amostras testadas por 5 minutos a espectroscopia Raman detectou os mesmos compostos em ambas os tipos de amostra (cinzento e vermicular): grafita, magnetita e hematita. Estes espectros são muito semelhantes aos colhidos dentro da trilha de desgaste das amostras testadas com apenas uma gota óleo com 1 hora de duração. A diferença importante está no valor de $I_{D} / I_{G}$ para cada amostra. Enquanto nas amostras testadas por 1 hora a diferença da relação $I_{D} / l_{G}$ entre as amostras de cinzento e vermicular era clara, nas amostras testadas por 5 minutos esta diferença se torna sutil. Os valores de $I_{D} / l_{G}$ encontrados nos espectros gerados após os ensaios de uma hora são menores do que os calculados após os ensaios de 5 minutos para o cinzento e maiores para o vermicular. Isto significa que o tribofilme formado a partir da grafita de vermicular aumenta seu grau de desordem com o decorrer do triboteste enquanto o grau de grafitização do tribofilme formado a partir da grafita de cinzento aumenta.

- Além do $\mathrm{MoS}_{2}$ as amostras testadas por 6 minutos também apresentaram na superfície da trilha de desgaste áreas de metal nascente. O restante da superfície da amostra de FC estava coberta por hematita. Já para a amostra de FV esta área restante estava recoberta por um filme constituído de grafita e $\mathrm{MoS}_{2}$.

- As fotos de MEV das trilhas de desgaste mostram que após o ensaio de 5 minutos a amostra FC apresenta menor quantidade de riscos de brunimento remanescentes e estes estão preenchidos com resíduos de desgaste (grafita mais óxidos). Além disto, na trilha de desgaste da amostra de FC não é possível detectar veios de grafita aflorando a superfície. Estas duas diferenças indicam que o a amostra de FC possui maior nível de desgaste após 5 minutos de ensaio e que preserva pouca ou nenhuma capacidade de fornecer mais grafita para a superfície de contato.

- Os mapas de EDS registrados após os ensaios de 5 minutos mostram que a amostra de FC possui quantidades consideravelmente maiores de O, P, S e Zn e uma quantidade semelhante de $\mathrm{C}$ em relação a amostra de FV. Também é possível perceber que o carbono está mais espalhado pela superfície da 
trilha da amostra de FC enquanto o FV preserva grande quantidade de grafita nos veios que ainda possuem acesso a superfície. O maior nível de desgaste da amostra de FC associado a maior quantidade de elementos formadores de tribofilme (O, P, S e Zn) indicam que a taxa de formação do tribofilme pode estar associada a taxa de desgaste ou taxa de exposição de metal nascente.

- As fotos de MEV da trilha de desgaste após o ensaio de 6 minutos mostram que a amostra de FC já não possui mais riscos de brunimento na superfície e as grafitas continuam sem acesso a superfície. A amostra de FV ainda preserva parte dos riscos mais profundos de brunimento, mas também já não possui mais grafitas aflorando a superfície.

- Os percentuais atômicos de cada elemento mostram que as quantidades de $\mathrm{O}, \mathrm{P}, \mathrm{S}$ e Zn são muito semelhantes entre a amostra de FC e FV após 6 minutos de ensaio. Porém, os mapas mostram que na amostra de FC há regiões de baixa concentração dos elementos citados na forma de sombra. Isto significa que aos 6 minutos de ensaio o tribofilme da amostra de FC já estava sendo removido enquanto na amostra de FV ele ainda permanecia íntegro. Outra diferença importante detectada está na quantidade de carbono das amostras. A quantidade de $\mathrm{C}$ na trilha de desgaste da amostra de FV é $\mathrm{O}$ dobro da registrada na amostra de FC. É importante registrar que 0 percentual de carbono da amostra de FC permanece constante entre 5 e 6 minutos de ensaio. Já para a amostra de FV a quantidade de carbono aos 6 minutos de ensaio é o dobro da registrada após 5 minutos.

- A imagem gerada pelo interferômetro ótico na superfície da trilha de desgaste da amostra de FC após o ensaio de 6 minutos mostra que já há a geração de crateras características de desgaste adesivo severo. 


\section{DISCUSSÕES}

Esta seção do trabalho será dedicada discutir e descrever os fenômenos tribológicos envolvidos no desgaste e no comportamento do coeficiente de atrito do sistema anel cilindro quando testado em tribômetro simulando o ponto morto superior de um motor de combustão interna.

$\mathrm{Na}$ seção 2.3 deste trabalho foram expostas duas classificações para os mecanismos de lubrificação limítrofe: a de Taylor [14] e a de Stachowiak [16]. Taylor [14] classifica os mecanismos de lubrificação limítrofe em:

- Camadas fisicamente adsorvidas de lubrificantes sólidos, líquidos ou gasosos.

- Camadas adsorvidas quimicamente ou quimissorvidas.

- Filmes formados por reações químicas.

A classificação de Stachowiak [16] segue abaixo com mais mecanismos que a de Taylor [13]

- Aumento da viscosidade próximo a superfície.

- Lubrificação por filmes adsorvidos.

- Lubrificação por "soap layers".

- Lubrificação por filmes amorfos.

- Lubrificação por filmes de sacrifício.

Para a descrição dos fenômenos triboquímico e a maneira como estes promoveram a lubrificação limítrofe nos testes que foram realizados neste trabalho será usada a classificação de Stachowiak [16]. Usando esta classificação como referência é possível descrever o tribossistema e as reações triboquímicas envolvidas nos testes com mais detalhe.

Além de usar a classificação de Stachowiak [16] como referência a descrição dos fenômenos triboquímico dos ensaios será feita relatando cada etapa do ensaio e como cada uma dela influenciou no comportamento do tribossistema. Os detalhes de cada etapa já foram descritos no capítulo 3 deste trabalho. Por isto, neste capítulo as etapas não serão detalhadas. As informações serão expostas de acordo com a sua necessidade para a compreensão do fenômeno triboquímico que estará sendo descrito. 
Antes dos tribotestes as amostras foram limpas por ultrassom com álcool etílico $(99,9 \%)$ durante 10 minutos. Este processo de limpeza fez com que a superfície das amostras ficasse com pouca oxidação e sem contaminação. Isto é confirmado pelas análises de MEV/EDS e Raman que foram feitas nas amostras antes dos ensaios. Nestas condições a reatividade da superfície é moderada e os aditivos que possuem maior afinidade pela superfície são os modificadores de atrito orgânicos, que se ligam com a superfície por adsorção. Portanto, quando a amostra foi colocada na SRV, presa ao porta-amostra e com o suprimento de óleo já adicionado (portaamostra cheio de óleo ou apenas uma gota), provavelmente já possuía uma camada de modificadores de atrito orgânicos adsorvidos a sua superfície.

Depois de fixado o porta-amostra à SRV o ensaio se inicia com a aplicação da précarga. Para todos os ensaios executados neste trabalho a pré-carga foi a mesma e igual a carga usada no ensaio, ou seja, $160 \mathrm{~N}$. A temperatura de ensaio usada em todos os testes foi de $120 \stackrel{\circ}{ } \mathrm{C}$ que é uma temperatura adequada para que ocorra a adsorção das moléculas dos modificadores de atrito orgânicos na superfície.

Depois que a pré-carga é aplicada é iniciado o processo de aquecimento e estabilização da temperatura da amostra. $O$ equipamento leva cerca de 5 minutos para atingir os $120{ }^{\circ} \mathrm{C}$ determinados para o ensaio. Os 5 minutos adicionais são necessários para que a amostra e o óleo também atinjam esta temperatura. Com a pré-carga aplicada e com a temperatura de ensaio estabilizada é dado início ao movimento de vai e vem do anel sobre a camisa com frequência de $50 \mathrm{~Hz}$ e um curso de $2 \mathrm{~mm}$.

Os primeiro 30 segundos de ensaio podem ser considerados como "acomodação" entre as superfícies. Este período de acomodação gera no gráfico de atrito de SRV um patamar com valores mais elevados. Isto está ilustrado no gráfico da figura 86 . 


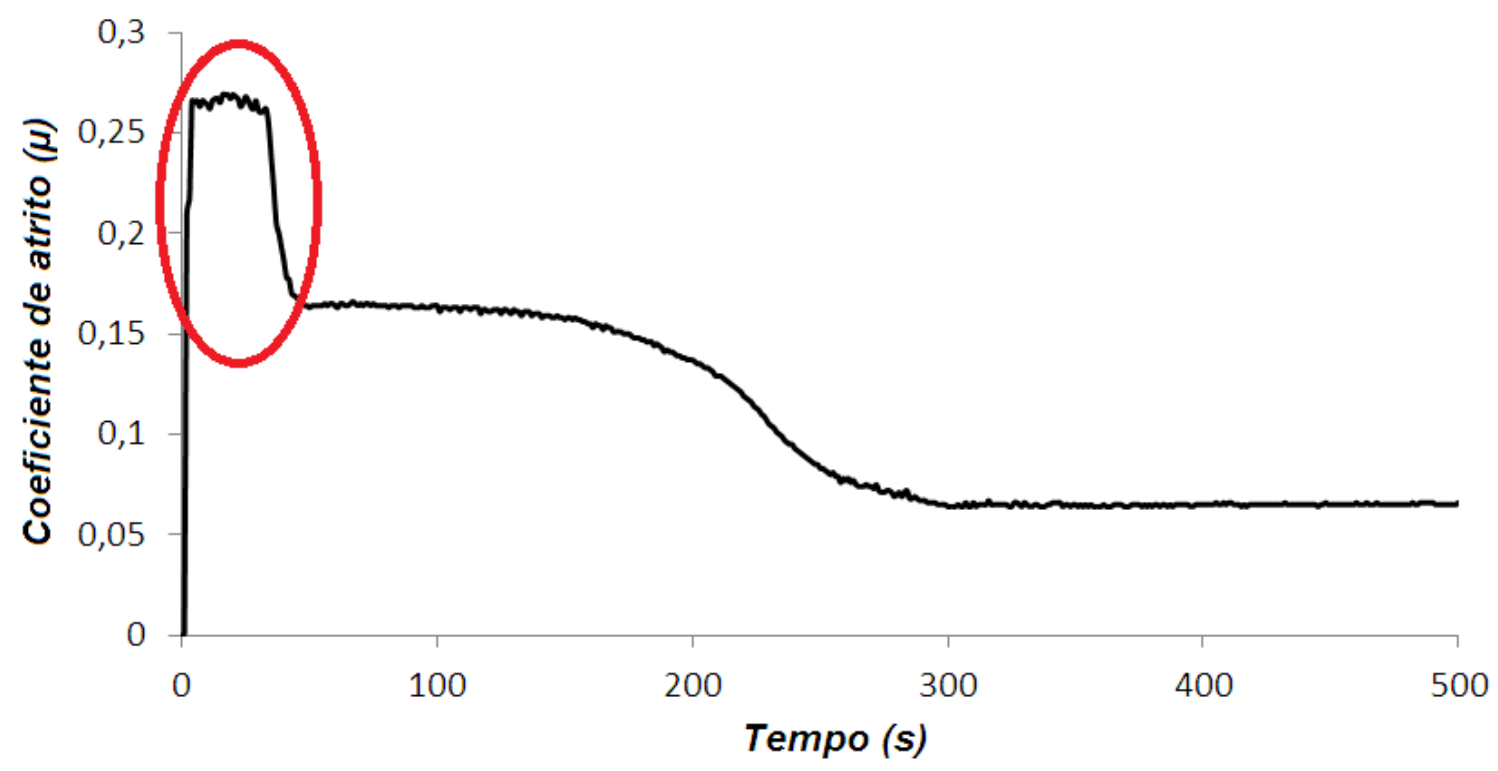

Figura 86 - Gráfico de coeficiente de atrito registrado pela SRV com destaque para o período de "acomodação" das superfícies.

Passado o período de acomodação e considerando a temperatura de ensaio (120 $\left.{ }^{\circ} \mathrm{C}\right)$ é esperado que a os modificadores de atrito orgânicos adsorvam na superfície e sejam removidos da superfície a cada passada do anel e que despois disto o óleo forneça novas moléculas para serem adsorvidas à superfície. Este mecanismo já foi proposto por Stachowiak [16] que inferiu que deve haver uma concentração mínima de modificadores de atrito orgânico disponível no tribossistema para que a reposição das moléculas adsorvidas na superfície seja reposta. Esta reposição deve acontecer com mais rapidez quanto maior for a quantidade de moléculas de modificadores de atrito orgânico disponíveis no tribossistema. Isto significa que este mecanismo de lubrificação deve ser mais efetivo nos ensaios executados com a amostra submersa em óleo. As curvas de atrito do gráfico da figura 87 reforçam esta hipótese. Neste gráfico estão colocadas todas as curvas de atrito já apresentadas neste trabalho no intervalo do ensaio entre 50 e $200 \mathrm{~s}$. Isto compreende o período entre a "acomodação" e a ativação do MoDTC (nos ensaios em que houve ativação). As curvas vermelhas são dos ensaios executados com a amostra submersa em óleo, as curvas verdes dos ensaios com apenas uma gota e óleo e as curvas azuis são dos ensaios com apenas uma gota de óleo e interrompidos. Neste gráfico é possível notar que os ensaios executados com apenas uma gota de óleo apresentam o coeficiente de atrito maior e menos estável que os ensaios feitos com a amostra submersa em óleo. 


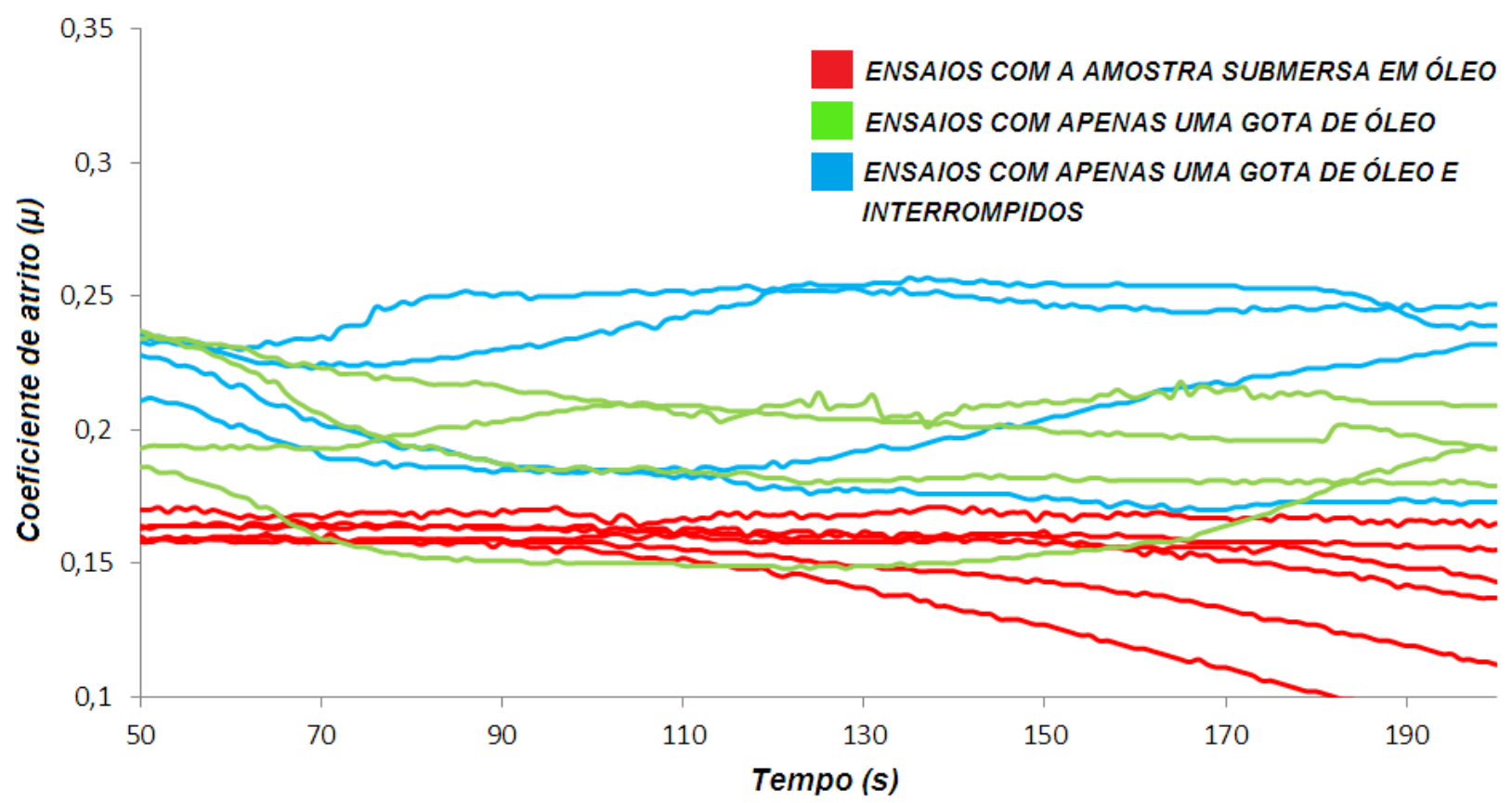

Figura 87 - Curvas de atrito de todos os ensaios executados neste trabalho no intervalo entre $50 \mathrm{e}$ 200 segundos.

Os resultados das análises após os tribotestes mostram que simultaneamente com a ação dos modificadores de atrito orgânico no início do ensaio há também a contribuição da grafita. A grafita age formando um filme de lubrificante sólido lamelar que reduz tensão de cisalhamento da interface e previne o contato entre as superfícies metálicas. Este filme lamelar se forma a partir das grafitas que se encontram na microestrutura das amostras e que tem acesso à superfície. Confirmando assim as hipóteses apresentadas por Guesser [77] e Zum Gahr [72] à respeito do papel das grafitas no comportamento tribológico dos ferros fundidos. Quando uma região próxima a este veio de grafita que possui acesso à superfície se deforma devidos às pressões de contato locais a grafita é extrudada para a superfície e passa a agir como lubrificante [96]. A grafita, porém, tem capacidade de atuação limitada nas condições testadas por duas razões. A primeira é que, como se trata de um composto lamelar, o anel carrega consigo parte do tribofilme e deposita nos pontos de reversão, fazendo com que o filme de grafita seja removido da região de contato, perdendo efetividade. A segunda razão é que a amostra possui uma capacidade limitada de fornecimento de grafita para o tribossistema uma vez que a deformação plástica da superfície promove o fechamento dos acessos que as 
grafitas possuem acesso à superfície. A atuação das grafitas nas condições testadas pode ser descrita de acordo com as etapas que seguem abaixo:

1. Extrusão da grafita para a superfície promovida pela deformação plástica localizada próxima aos veios que possuem acesso à superfície.

2. Distribuição da grafita pela superfície da trilha de desgaste e alinhamento das lamelas perpendicularmente a superfície.

3. Acúmulo de grafita nos riscos de brunimento.

4. Fechamento dos acessos das grafitas à superfície devido a deformação plástica.

5. Remoção do filme de grafita e deposição nas bordas dos pontos de reversão devido a passagem do anel.

6. Consumo da grafita acumulada nos riscos de brunimento.

7. Falha do filme.

As etapas descritas não acontecem de forma isolada, ou seja, uma etapa não se inicia apenas após o final da anterior. As etapas possuem sobreposição umas com as outras. Porém, as etapas descritas estão na ordem do seu término. Isto significa que a etapa 2 terminará depois da um, a 3 depois da 2 e assim sucessivamente até a falha do filme.

Nas amostras testadas submersas em óleo a atuação da grafita atingiu o estágio 6 sem completá-lo. Isto pode ser concluído analisando os mapas de EDS das trilhas de desgaste após os tribotestes. Nestes mapas não são detectados veios de grafita abertos à superfície e as regiões de maior concentração de grafite são os riscos de brunimento. Isto significa que na condição de amostra submersa em óleo após 6 horas de ensaio a "reserva" de grafita do tribossistema ainda não havia sido completamente consumida. Isto pode ser observado na tabela 30 . 
Tabela 30 - Mapas de EDS para o C das amostras testadas submersas em óleo.

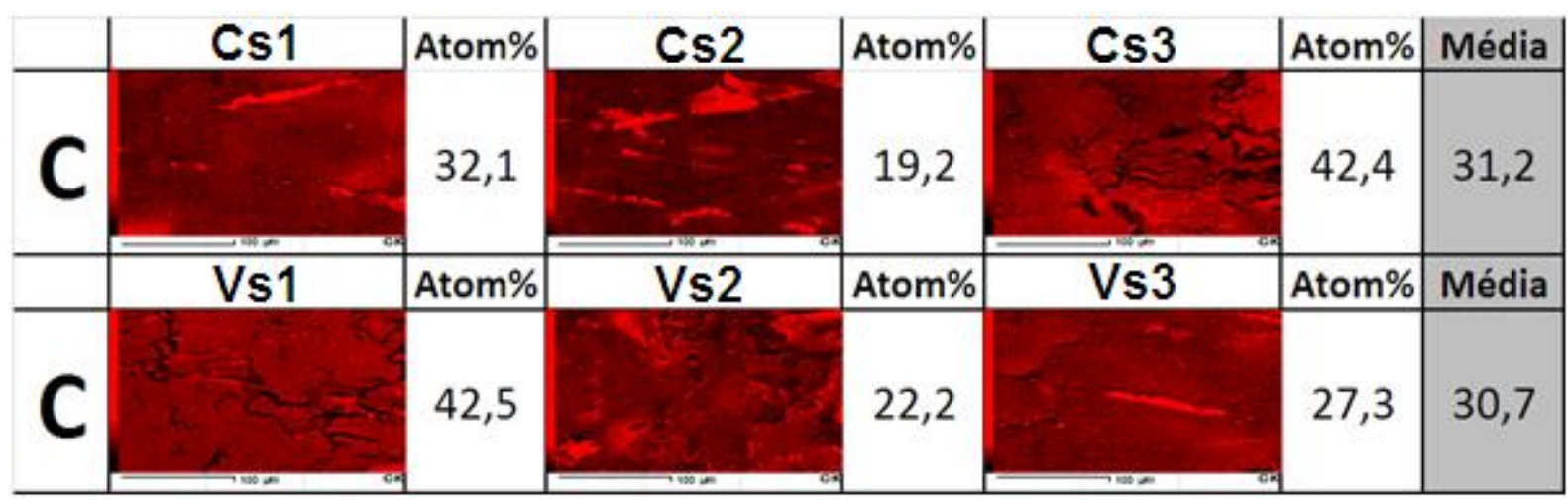

A quantidade elevada de carbono na superfície, superior a todos os ensaios realizados com apenas uma gota de óleo, indica que parte deste carbono pode estar na forma de tribofilme formado a partir dos modificadores de atrito orgânicos que Stachowiak [16] denomina "soap layers".

Uma vez determinados os mecanismos de atuação da grafita será retomada descrição dos fenômenos triboquímicos na ordem que eles acontecem ao longo do ensaio.

Como nos ensaios realizados com apenas uma gota de óleo a efetividade dos modificadores de atrito na lubrificação é menor também é formado um filme de óxidos na superfície que é composto por hematita e magnetita. Com isto, para as amostras testadas com apenas uma gota de óleo a descrição dos fenômenos triboquímicos até os 200 segundos de ensaios está completa com o que já foi apresentado, com exceção da atuação da grafita que será detalhada posteriormente. Porém, para as amostras testadas submersas em óleo a formação do filme de ZDDP também acontece neste intervalo de tempo. Os resultados de espectroscopia Raman e de EDS mostram que o filme de $\mathrm{MoS}_{2}$ se forma sobre o filme de ZDDP.

Esta análise vai ao encontro dos resultados encontrados na literatura em que foram usadas técnicas microscopia de força atômica e ensaios de nanoriscamento para determinar que há a formação de uma fina camada de $\mathrm{MoS}_{2}$ sobre o tribofilme de ZDDP quando o MoDTC e o ZDDP são usados juntos no óleo [31, 115 -117].

Portanto é razoável inferir que a formação das cadeias de polifosfato provenientes da reação do ZDDP com a superfície ocorre antes da formação do filme de $\mathrm{MoS}_{2}$. A queda brusca do coeficiente de atrito, característica da ativação do MoDTC, tem 
início entre 100 e 200 segundos para as amostras testadas submersas em óleo, como pode ser observado na figura 58.

Depois que o MoDTC é ativado e a trilha de degaste é recoberta com um filme de $\mathrm{MoS}_{2}$, este passa controlar o coeficiente de atrito do tribossistema enquanto o ZDDP promove a proteção da superfície contra o desgaste adesivo. Ao final do ensaio das amostras testadas submersas em óleo foram notadas crateras provocadas por desgaste por fadiga de contato. Portanto, o mecanismo de desgaste predominante quando há um tribofilme bem constituído protegendo a superfície do contato direto entre o anel e a amostra é o de fadiga de contato, resultado dos esforços cíclicos promovidos por cada passagem do anel. Este mecanismo também foi descrito por Obara [7] e Santos Filho [12] quando avaliaram o desgaste próximo ao ponto morto superior de motores reais.

Nos tribotestes realizados com apenas uma gota de óleo o tempo de 200 segundos não representa nenhuma transição importante no comportamento do tribossistema. As análises de EDS dos ensaios com apenas uma gota e interrompidos mostram que o tribofilme a partir do ZDDP começa a se formar por volta dos 240 segundos. $O$ que mantem o desgaste em um nível moderado antes da formação do tribofilme de ZDDP é a atuação da camada de óxidos, formada por magnetita e hematita, e do filme de grafita.

Nos ensaios realizados com apenas uma gota de óleo a amostra Cg2 começou apresentar elevação do coeficiente de atrito, indicando o início do processo de "scuffing", após, aproximadamente, 250 segundos do início do ensaio e a amostra Cg1 teve o mesmo comportamento a partir de 650 segundos de ensaio, como pode ser visto nos gráficos da figura 71 .

Os ensaios interrompidos após 5 minutos mostraram que neste tempo de ensaio, ou seja, após aproximadamente 300 segundos, a amostras de ferro fundido cinzento já não possui mais grafitas com acesso a superfície. Isto significa que neste ponto do ensaio a amostra já não preservava mais a capacidade de fornecer grafita para o tribossistema. Obara [7] também identificou o recobrimento dos acessos das grafitas à superfície como resultado de deformações plásticas na superfície.

A amostra de ferro fundido vermicular ainda possuía uma quantidade considerável de grafitas com acesso à superfície. Neste ponto do ensaio o tribofilme sobre a amostra de FC apresenta $0,8 \%$ de $P, 0,4 \%$ de $S$ e $0,6 \%$ de Zn. A amostra de FV 
possuía $0,2 \%$ de $\mathrm{P}, 0,1 \%$ de $\mathrm{S}$ e $0,1 \%$ de $\mathrm{Zn}$. Isto significa que o tribofilme formado a partir do ZDDP estava mais bem desenvolvido na amostra de FC. Esta informação associada ao fato de que a superfície já não possuía riscos de brunimento remascentes e que os veios de grafita da superfície já estavam fechados indica que o processo de desgaste acelera a formação do tribofilme de ZDDP. A amostra de FV, após 5 minutos de ensaio, ainda preservava uma boa quantidade de riscos de brunimento na trilha de desgaste o que mostra que esta apresentava um menor nível desgaste que a amostra de FC.

Nas amostras ensaiadas por 6 minutos é possível notar que o tribofilme de ZDDP já está constituído tanto para a amostra FC quando para a de FV. Nas duas amostras também foram encontradas pequenas quantidades de $\mathrm{MoS}_{2}$ na trilha de desgaste. $\mathrm{Na}$ amostra de FC, usando espectroscopia Raman, foi detectada a presença de hematita e não foram encontrados picos relativos à grafita. Na trilha de desgaste da amostra de FV não foi detectada a presença de hematita, mas um filme de grafita foi encontrado junto com $\mathrm{MoS}_{2}$. Isto indica que a amostra de FC já havia atingido a etapa 7 de atuação do tribofilme formado a partir da grafita. A quantidade de $\mathrm{MoS}_{2}$ formada nos ensaios com apenas uma gota não é suficiente para promover a queda no coeficiente de atrito.

Os ensaios com apenas uma gota e interrompidos mostraram que as amostras de FC não suportaram o ensaio de 1 hora porque não há aditivo suficiente para formar um tribofilme tão eficiente quanto o formado nos ensaios com a amostra submersa em óleo. Além disto, o tribofilme formado a partir das grafitas lamelares dos FC tem menor durabilidade que o filme formado a partir das grafitas vermiculares do FV. Esta diferença durabilidade é confirmada pelo ensaio de espectroscopia Raman realizado após os ensaios com apenas uma gota. Estes mostram que o tribofilme formado a partir da grafita do $\mathrm{FC}$ possuía uma relação $\mathrm{I}_{\mathrm{D}} / \mathrm{I}_{\mathrm{G}}$ significativamente inferior à registrada nas amostras de FV. Isto pode ser observado nos espectros da figura 66.

Esta diferença de durabilidade dos tribofilmes formados a partir dos dois diferentes tipos de grafita (lamelar e vermicular) não era esperada antes dos ensaios porque as análises de espectroscopia Raman das grafitas na microestrutura do material não mostraram diferenças na relação $I_{D} / l_{G}$ entre as grafitas lamelar, vermicular e nodular. Por isto, a hipótese proposta neste trabalho é que o processo de extrusão da grafita 
promovido pelas pressões de contato impostas próximas aos veios que possuem acesso a superfície ocorre de maneira diferente quando comparamos o FC e o FV. A figura 88 mostra a organização espacial da grafita dentro de uma célula eutética. Neste tipo de grafita o crescimento se dá principalmente na direção do plano basal e do centro da célula eutética para fora.

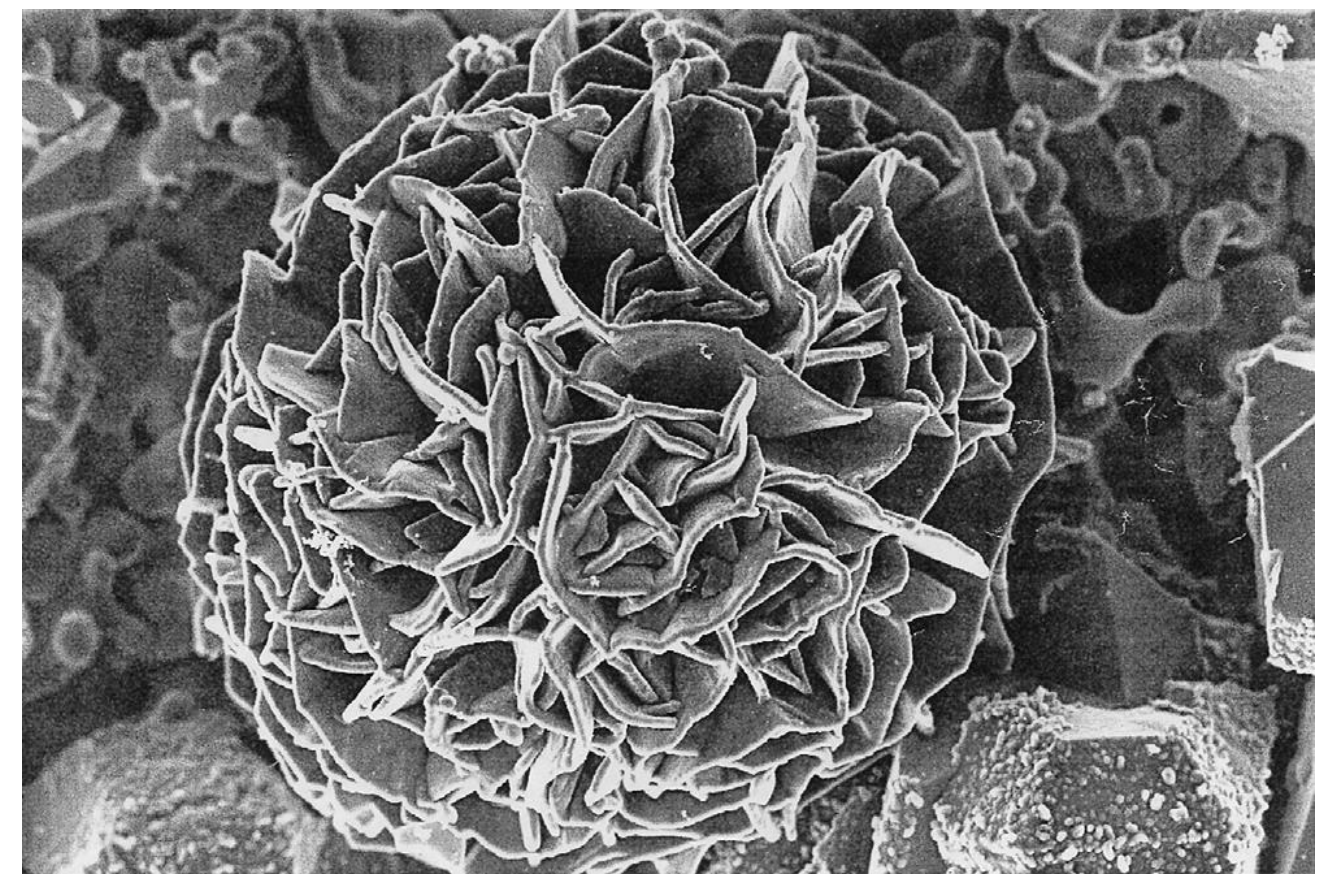

Figura 88 - Grafita de ferro fundido cinzento [90]

Isto significa que não importa como o plano da superfície corta a grafita ela estará sempre com o seu plano basal "apontado" para o acesso à superfície. Esta característica facilita sobremaneira a extrusão das grafitas lamelares para a superfície. O processo de extrusão das grafitas lamelares, portanto, promove a formação de um tribofilme de grafita com seu plano basal bastante alinhado com a superfície, o que confere ao filme baixa tensão de cisalhamento e baixa durabilidade porque o filme é facilmente carregado pelo anel e depositado nos pontos de reversão. A figura 26 traz uma representação da estrutura cristalográfica da grafita. Nela é possível identificar o plano basal do cristal e a direção preferencial de crescimento da grafita lamelar que é a direção $\boldsymbol{a}$.

Diferentemente da grafita lamelar, a grafita vermicular alterna seu crescimento entre a direção a e a direção $\boldsymbol{c}$, como está ilustrado na representação da figura 89. Isto significa que das grafitas que possuem acesso à superfície apenas parte delas 
estará com o plano basal "apontado" para a saída para a superfície da amostra. Isto dificulta a extrusão da grafita e torna organização dos cristais de grafita aleatória em relação a superfície, ou seja, parte dos cristais terá o plano basal alinhado com a superfície, promovendo baixa tensão de cisalhamento e outra parte terá o plano basal desalinhado, oferecendo a face prismática, que possui alta tensão de cisalhamento e dificulta que a grafita seja arrastada para fora de trilha de degaste pelo anel, conferindo assim maior durabilidade ao tribofilme.

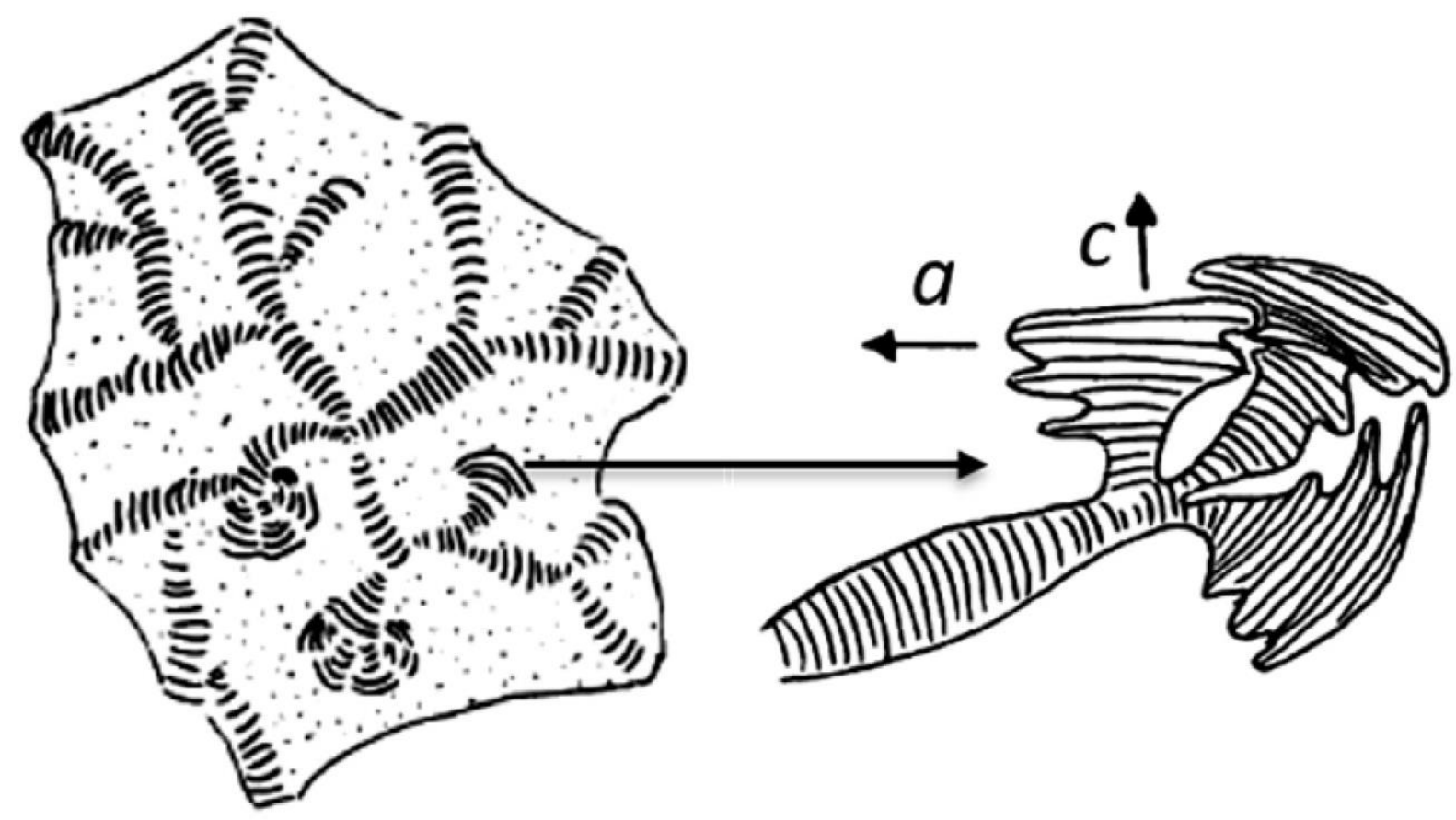

Figura 89 - Representação do crescimento da grafita vermicular preferencialmente na direção $c$ [78].

Além da forma como ocorre o crescimento da grafita, outro fator que tem influência no processo de extrusão da grafita para a superfície de contato é a interface entre a grafita e microestrutura. Guesser [95] estudando a fratura por fadiga de ferros fundidos cinzentos e vermiculares mostrou que a interface entre e o veio de grafita e a matriz no ferro fundido cinzento é bastante lisa e regular. Esta interface no ferro fundido vermicular é bastante rugosa. Isto significa que a grafita vermicular está mais ancorada na matriz e isto dificulta o deslizamento dos cristais de grafita para a superfície. 


\section{CONCLUSÕES}

Quando submetidos a condições que simulam o ponto morto superior de motores de combustão interna com óleos que possuem MoDTC na sua formulação e com as análises realizadas neste trabalho é possível concluir que:

- Não existe diferença significativa entre os tribofilmes formados nas superfícies das amostras a partir dos aditivos do óleo quando as amostras são testadas submersas em óleo. Nesta configuração de ensaio formou-se um tribofilme de ZDDP recoberto por MoS2 proveniente da ativação do MoDTC.

- A quantidade de óleo é determinante para o desempenho do tribossistema. Quando existe oferta abundante de aditivos há a formação de um tribofilme bem constituído que reduz significativamente o desgaste e o coeficiente de atrito. Na situação de escassez de óleo, o tribofilme formado a partir dos aditivos é rapidamente removido, com cerca de uma 1 hora para as amostras de FV e em poucos minutos para as amostras de FC, e o tribossistema fica sujeito a ocorrência de scuffing.

- Nos ensaios realizados com apenas uma gota a ativação do MoDTC ocorre, mas não gera quantidade suficiente de MoS2 para promover a queda significativa no coeficiente de atrito. Nesta configuração o tribofilme formado a partir da grafita passa ter grande importância na resistência ao scuffing do tribossistema.

- A grafita tem um papel fundamental para o desempenho do tribossistema quando opera com pequena quantidade de óleo. Ele já atua como lubrificante sólido antes da formação do tribofilme a partir dos aditivos do óleo. Depois que o tribofilme se forma ela continua suportando parte da carga, contribuindo assim para uma maior durabilidade do tribofilme. Depois que o tribofilme dos aditivos é completamente removido o tribofilme de grafita continua atuando prevenindo o scuffing. O scuffing só ocorre quando o tribofilme de grafita é removido e há contato direto entre as superfícies do anel e do cilindro. 
- A grafita vermicular apresentou um desempenho melhor do que a grafita lamelar, com maior capacidade de prevenir o scuffing. A forma como elas são extrudadas e as suas morfologias são diferentes e promovem a formação de tribofilmes com características diferentes. Estas diferenças fazem com que o tribofilme de grafita vermicular possua um maior valor da relação $I_{D} / l_{G}$ e tenha, consequentemente, maior durabilidade e maior capacidade de prevenir os scuffing. 


\section{SUGESTÕES PARA TRABALHOS FUTUROS}

Foram levantadas hipóteses neste trabalho que podem ser confirmadas através da realização de tribotestes de configuração simples como pino sobre disco, por exemplo. Além disto, há questões que podem ser aprofundadas para contribuir para a melhor compreensão dos fenômenos triblógicos específicos dos ferros fundidos devido à presença da grafita na sua microestrutura. Portanto, os seguintes trabalhos podem ser sugeridos.

> Realizar ensaios comparando o comportamento da grafita e do tribossistema utilizando apenas óleo base com óleos totalmente formulados.

> Verificar a hipótese de que a grafita lamelar é carregada com mais facilidade pelo contra corpo do que a grafita vermicular comparando o comportamento dos ferros fundidos cinzentos e vermiculares em ensaios de pino sobre disco com movimento de vai e vem e movimento circular.

> Fazer ataque profundo em amostras de ferro fundido cinzento e vermicular para expor as grafitas e submeter a ensaios de pino sobre disco para avaliar se a diferença de comportamento tribológico das grafitas é decorrente da sua morfologia ou da maneira como é estrudada para a superfície.

> Medir o módulo de elasticidade da matriz do ferro fundido cinzento e do vermicular usando um nanoindentação para avaliar se esta propriedade pode ter influenciado nas características do contato e consequentemente no comportamento tribológico de cada tipo de ferro fundido.

> Estudar a influência do tempo de ensaio no grau de alinhamento das lamelas da grafita com a superfície. 


\section{APÊNDICE - Alinhamento do anel e da camisa para execução do triboteste}

O processo de alinhamento do anel com a amostra cilindro é crítico para a realização dos tribotestes porque é preciso garantir um contato conforme entre eles. Este contato conforme garante que todas as amostras serão ensaiadas com a mesma pressão de contato.

O processo de alinhamento foi realizado em um dispositivo desenvolvido para este fim. Este dispositivo está ilustrado na figura 90.

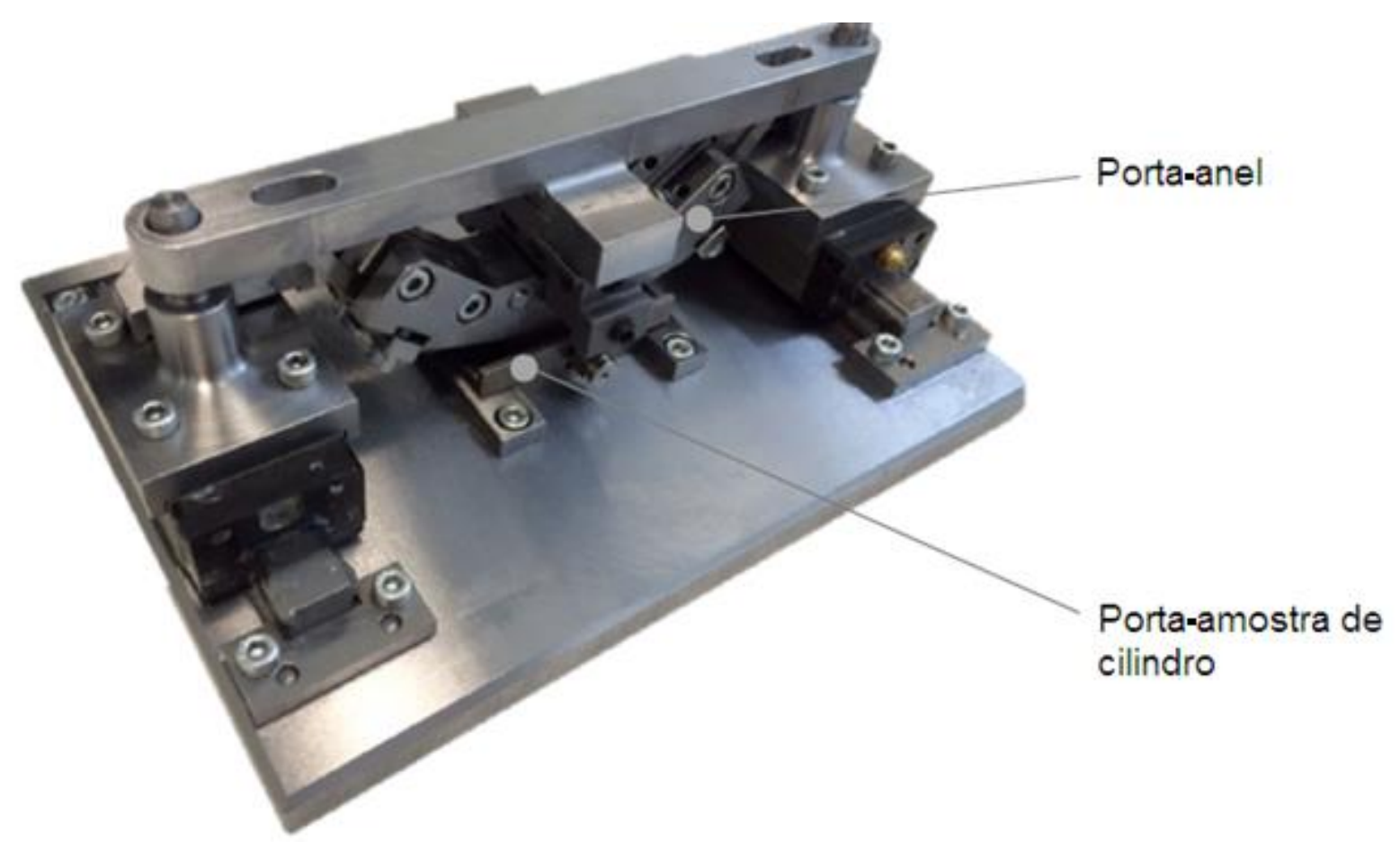

Figura 90 - Dispositivo para alinhamento do anel com a amostra de cilindro.

O primeiro passo do processo de alinhamento é fixar a amostra de cilindro no seu respectivo porta-amostra. A amostra de cilindro deve entrar justa no alojamento do porta-amostra para garantir o seu alinhamento com o movimento de vai e vem do anel. Depois, é feito o aperto do parafuso de fixação para garantir que a amostra não se movimente ou se desprenda do porta-amostra. 


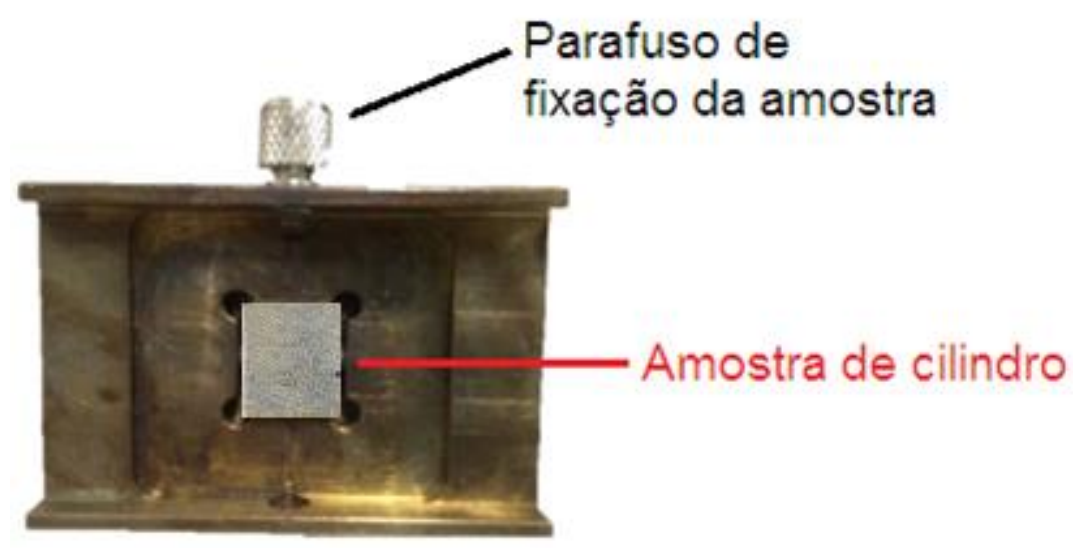

Figura 91 - Amostra de cilindro fixada no porta-amostra.

Em seguida o anel é fixado no porta-anel. Para a fixação, o anel é passado por baixo das duas chapas de ajuste do raio do anel e pré-fixado pelos parafusos de fixação. O aperto destes parafusos não pode ser muito grande porque limitará o ajuste do raio. Depois de pré-fixar é necessário ajustar o raio através dos parafusos de ajuste do raio. $O$ porta-anel e os seus elementos estão ilustrados na figura 92.

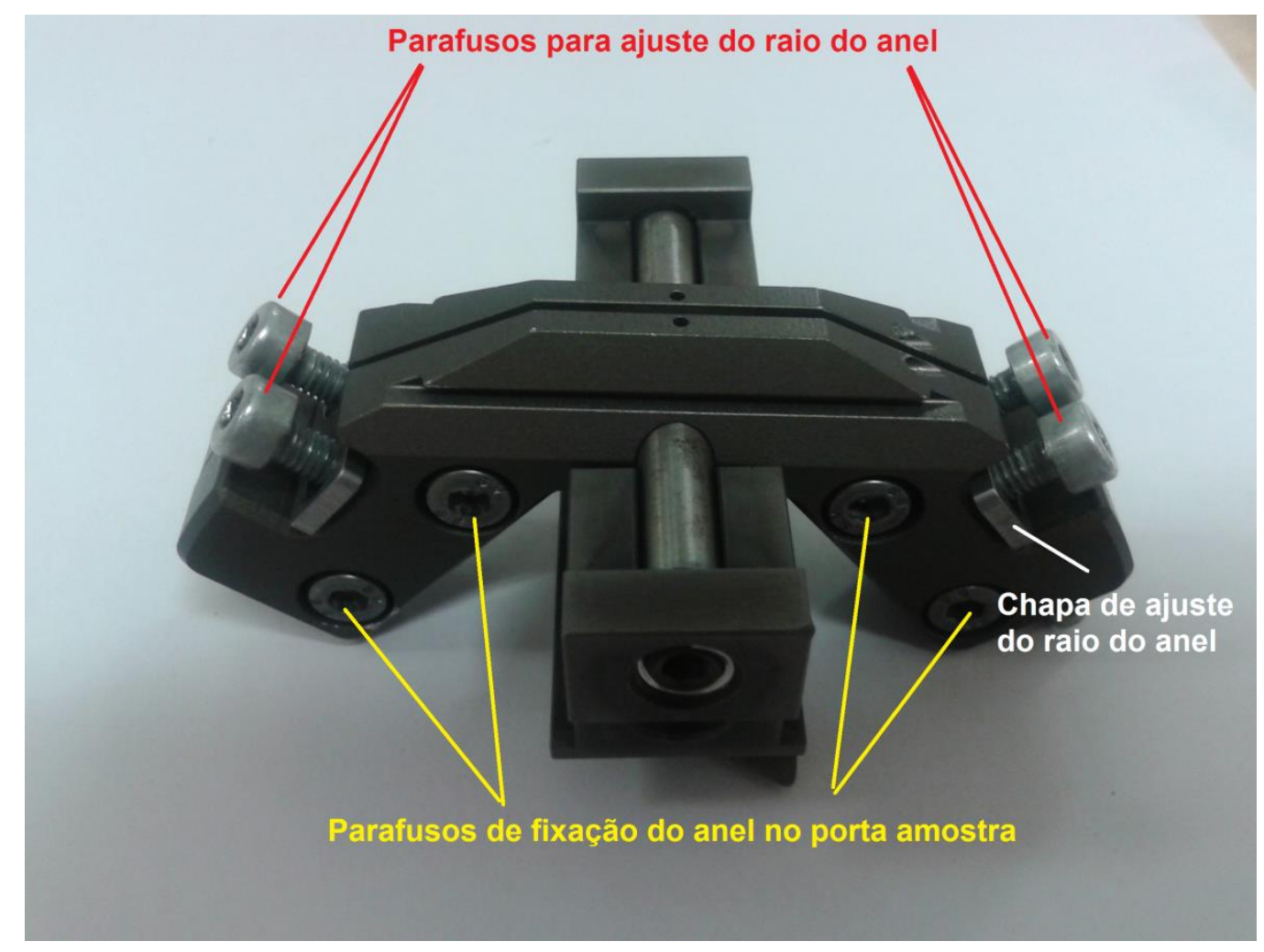

Figura 92 - Porta-anel e seus elementos. 
Depois de fixar o anel a amostra de cilindro que está no porta-amostra deve ser pintada com pincel atômico para que verificar se o contato entre anel e amostra do cilindro acontecerá de maneira conforme. O porta-amostra e o porta-anel são, então, fixados no dispositivo de verificação de alinhamento. O alinhamento é verificado pressionando manualmente $\mathrm{o}$ anel contra a amostra de cilindro e promovendo um movimento de vai e vem. Para que o contato seja considerado conforme o aspecto da amostra após este procedimento deve apresentar uma remoção uniforme da tinta ao longo do contato conforme ilustrado na figura 93.

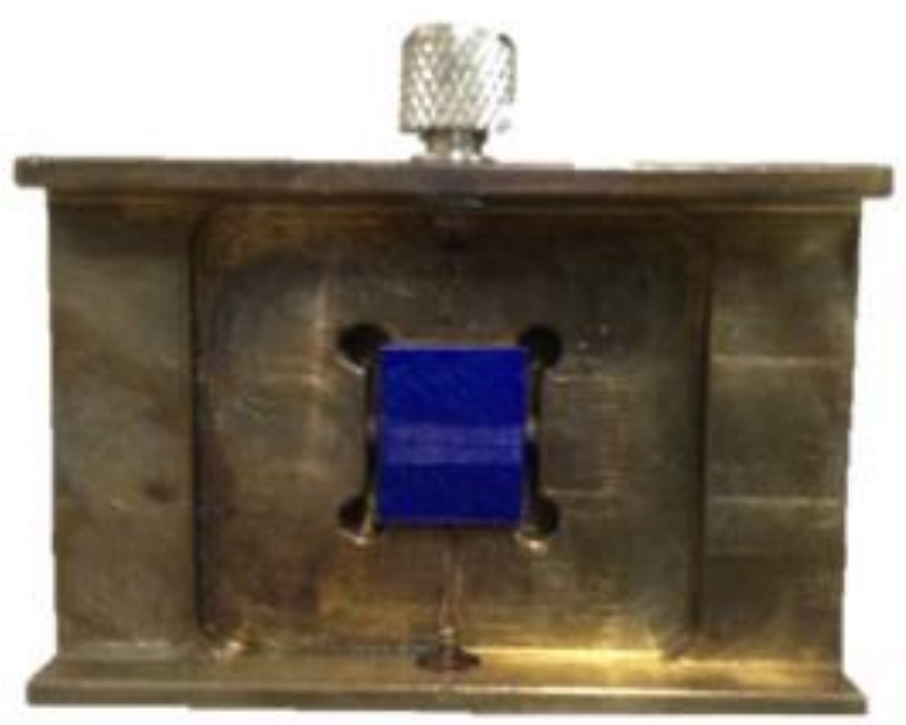

Figura 93 - Contato conforme, indicando que o alinhamento entre o anel e a amostra é adequado para a execução do ensaio.

A figura 94 apresenta remoções da tinta do pincel atômico que indicam desalinhamento, com o anel excessivamente aberto ou excessivamente fechado. 

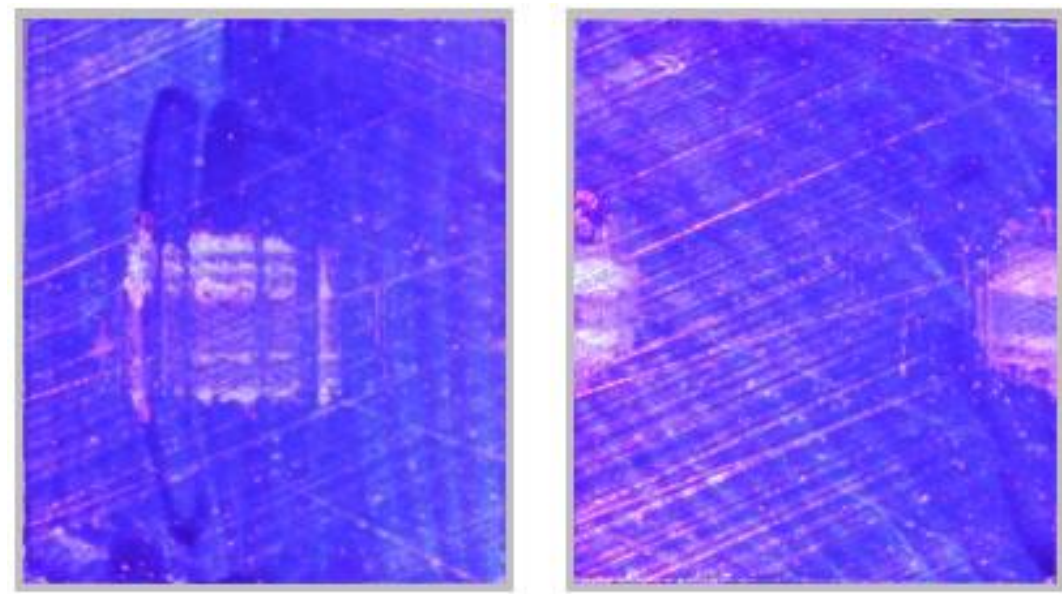

Figura 94 - À esquerda um alinhamento incorreto com o anel excessivamente fechado e à direita um exemplo de anel excessivamente aberto.

Para garantir que 0 alinhamento foi efetivo e se manteve durante 0 ensaio $o$ aspecto da amostra após o triboteste deve ser semelhante ao da amostra da figura 95. Caso a amostra não apresente este aspecto o ensaio deve ser descartado.

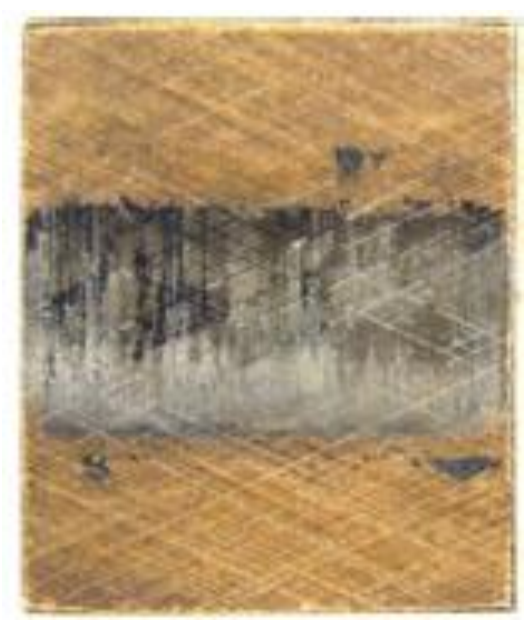

Figura 95 - Amostra submetida ao triboteste com o alinhamento entre anel e amostra de cilindro adequado. 


\section{REFERÊNCIAS BIBLIOGRÁFICAS}

[1] Blau P, Friction science and technology - from concepts to applications. Second Edition. New York: STLE: CRC Press, Taylor \& Francis Group; 2009

[2] Rosenberg RC, General Friction Considerations for Engine Design, Society of Automotive Engineers, Spec. Pub. 532, Paper No. 821576, p. 59. 1982.

[3] Homberg K, Anderson P, e Erdemir A, Global energy consumption due to friction in passenger cars, Tribology International 47, 2012, p. 221-234.

[4] Franco LA, Abrasão de ferro fundido cinzento: Aplicação a motores automotivos. Tese (Doutorado), Escola Politécnica, Universidade de São Paulo, São Paulo, 2015.

[5] Söderfjäll M, Friction in Piston Ring - Cylinder Liner Contacts, Doctoral Thesis, Luleå University of Technology - Department of Engineering Science and Mathematics - Division of Machine Elements, 2017.

[6] Priest M, Factors influencing boundary friction and wear of piston rings. Tribology series 38:409-416, 2000.

[7] Obara RB, Avaliação do desgaste em cilindros de motores de combustão interna - Mapeamento de mecanismos e quantificação do desgaste. Tese (Doutorado em Engenharia Mecânica) - USP, 2018.

[8] Chen H, Li Y, and Tian T, A Novel Approach to Model the Lubrication and Friction between the Twin-Land Oil Control Ring and Liner with Consideration of Micro Structure of the Liner Surface Finish in Internal Combustion Engines. SAE Technical Paper, 2008-01-1613, 2008.

[9] Johansson S, A Surface Engineering Approach to Reduction of Frictional Losses of Heavy Duty Diesel Engines. PhD thesis, Chalmers University of Technology, 2012. [10] Richardson DE, Review of power cylinder friction for diesel engines, Journal of Engineering for Gas Turbines and Power, vol. 122, no. 4, pp. 506-519, 2000.

[11] Taylor CM, Automobile engine tribology - Design considerations for efficiency and durability. Wear. v.221, p. 1-8, 1998.

[12] Santos Filho D, Alterações metalúrgicas e topográficas do cilindro de motor de combustão interna flex-fuel. São Paulo: Universidade de São Paulo; 2013

[13] Trindade ED, Efeito do tipo de óleo básico no desempenho tribológico de dialquilditiocárbámáto de molibdênio como aditivo para lubrificantes automotivos. Dissertação de Mestrado, 2014. 
[14] Taylor CM, Engine Tribology, (Elsevier Science Publ.), 1993.

[15] Rizvi SQA, A comprehensive review of lubricant chemistry, technology, selection and design. (West Conshohocken, PA: ASTM International, 2009), 0-FM10.

[16] Stachowiak GW, Batchelor AW, Engineering Tribology. Fourth Edition, 2013.

[17] Zhang J, Spikes H, On the Mechanism of ZDDP Antiwear Film Formation. Tribol. Lett. 63, 24 (2016).

[18] Dawczyk J, Morgan N, Russo J, Spikes H, Film Thickness and Friction of ZDDP Tribofilms. Tribol. Lett. 67, 34 (2019)

[19] Ueda M, Kadiric A, Spikes H, On the Crystallinity and Durability of ZDDP Tribofilm. Tribol. Lett. 67, 123 (2019).

[20] Spikes H, "The history and mechanisms of ZDDP”, Tribology Letters, Vol. 17, No. 3, October 2004.

[21] Martin JM, Lubricant additives and the chemistry of rubbing surfaces: metal dithiophosphates triboreaction films revisited. Jpn. J. Tribol. 1997;42(9).

[22] Martin JM, Grossiord C, Mogne TL, Bec S, Tonck A, The two-layer structure of Zndtp tribofilms Part I. AES, XPS and XANES analyses. Tribology International $2001 ; 34: 523-30$.

[23] Bailey MW, and Cameron A, The Effects of Temperature and Metal Pairs on Scuffing, ASLE Transactions, Vol. 16, 1973, pp. 121-131.

[24] Tang Z, Li S, A review of recent developments of friction modifiers for liquid lubricants (2007-present). Curr. Opin. Solid State Mater. Sci. 18, 119-139 (2014).

[25] Fujitsu T, Griffiths J, Lubricating oil composition. US 2006/0189489 A1; 2006.

[26] Acero JSR, Influência do acabamento superficial no desempenho de lubrificantes de motor novos e usados em automóveis abastecidos com E22 e E100. Dissertação de Mestrado em Engenharia Mecânica, Universidade de São Paulo, 2015.

[27] Wells HM, Southcombe JE, The theory and practice of lubrication: the "germ" process. J. Soc. Chem. Ind 1920;39:51T.

[28] Rudnick L, Lubricant additives: chemistry and applications. New York: Marcel Dekker; 2008.

[29] Crawford J, Psaila A, Miscellaneous Additives. London, 1992, pp. 160-165. 
[30] Buckley HL, Touchberry CH, McKinley JP, Mathe ZS, Muradyan H, Renewable Additives that Improve Water Resistance of Cellulose Composite Materials. Journal of Renewable Materials, 5(1), 1-13. 2017.

[31] Spikes H, 2015, Friction Modifier Additives, Tribology Letters, Vol: 60, ISSN: 1023-888

[32] Langmuir I, The mechanism of the surface phenomena of flotation. Trans Faraday Soc 1920;15:62.

[33] Levine O, Zisman W, Physical properties of monolayers adsorbed at the solidair interface. I. Friction and wettability of aliphatic polar compounds and effect of halogenation. J. Phys. Chem. 1957;61:1068.

[34] Beltzer M, Jahanmir S, Effect of additive molecular structure on friction. Lubr. Sci. 1988;1:3.

[35] Jahanmir S, Chain length effects in boundary lubrication. Wear 1985;102:331.

[36] Jahanmir S, Beltzer M, Effect of additive molecular structure on friction coefficient and adsorption. J. Tribol. 1986;108:109.

[37] Deryaguin B, Karassev V, Zakhavaeva N, Lazarev V, The mechanism of boundary lubrication and the properties of the lubricating film: short- and long-range action in the theory of boundary lubrication. Wear 1958;1:277.

[38] Allen C, Drauglis E, Boundary layer lubrication: monolayer or multilayer. Wear 1969;14:363.

[39] Smith A, Cameron A, Rigid surface films. Proc R Soc Lond A, Math Phys Sci 1972;328:541.

[40] Anghel V, Bovington $\mathrm{C}$, Spikes $\mathrm{H}$, Thick-boundary-film formation by friction modifier additives. Lubr. Sci. 1999;11:313.

[41] Ratoi M, Anghel V, Bovington C, Spikes H, A Mechanisms of oiliness additives. Tribol Int 2000;33:241.

[42] Campen, SM, Fundamentals of organic friction modifier behaviour. PhD Thesis, Imperial College London (2012).

[43] Spikes HA, Cameron A, A comparison of adsorption and boundary lubricant failure. Proc. R. Soc. Lond. A336, 407-419 (1974).

[44] Jahanmir $S$, Beltzer $M$, Effect of additive molecular structure on friction coefficient and adsorption. Trans. ASME J. Tribol. 108, 109-116 (1986). 
[45] Mitchell D, "Oil-Soluble Mo-S Compounds as Lubricant Additives" Wear, 100, pp 281-300, 1984.

[46] Vanderbilt RT, Molybdenum-containing dithiophosphoric ester compounds, UK Patent 1144145. 1966.

[47] Sakurai T, Okabe $H$, Isoyama $H$, The synthesis of di-m-thio-dithiobis(dialkyldithiocarbamates) dimolybdenum (V) and their effects on boundary Lubrication, Bull. Japan Petr. Inst. ,13,308-314). 1971.

[48] Braithwaite ER, Greene AB, A critical analysis of the performance of molybdenum compounds in motor vehicles, Wear, 46 p. 405, 1978.

[49] Passut CA, Kollman RE, Laboratory techniques for evaluation of engine oil effects on fuel economy, SAE Tech. Paper 780601. 1978

[50] De Feo M, Minfray C, De Barros Bouchet MI, Thiebaut B, Martin JM, MoDTC friction modifier additive degradation: Correlation between tribological performance and chemical changes, RSC Adv., 2015, 5, 93786.

[51] Graham, J, Korcek S, Spikes HA, The friction-reducing properties of molybdenum dialkyldithiocarbamate additives. Part 1. Factors influencing friction reduction. Tribol. Trans. 44, 626-636 (2001).

[52] Grossiord C, Varlot K, Martin JM, Mogne TL, Esnouf C, Inoue K, MoS2 single sheet lubrication by molybdenum dithiocarbamate. Tribology International 1998; 31(12):737-43.

[53] Khaemba DN, Neville A, Morina A, "New insights on the decomposition mechanism of Molybdenum Dialkyldithiocarbamate (MoDTC): a Raman spectroscopic study", RSC Adv., 2016, 6, 38637.

[54] Buckley DH, Surface Effects in Adhesion, Friction, Wear and Lubrication. Elsevier, Amsterdam, 1981.

[55] Mori S, Boundary Lubrication form de Viewpoint of Surface Chemistry - Role of nascent surface on tribochemical reaction of lubricant additives. JTEKT Engineering journal, English Edition No. 1008E, 2011.

[56] Morecroft DW, Reactions of Octadecane and Decoic Acid with Clean Iron Surfaces, Wear, Vol. 18, 1971, pp. 333-339.

[57] Minami I, Furesawa T, Kubo T, Nanao H, Mori S, Investigation of tribochemistry by means of stable isotopic tracers: mechanism for durability of monomolecular boundary film. Tribology International, 2008; 41:1056. 
[58] Topolovec-Miklozic K, Forbus TR, Spikes H, Performance of friction modifiers on ZDDP-generated surfaces. Tribology Transactions 50, 328-335 (2007).

[59] Yajun M, Wancheng Z, Shenghua L, Yuansheng J, Yucong W, Simon T, Tribological performance of three advanced piston rings in the presence of MoDTCmodified GF-3 oils. Tribology Letters. 18, 75-83 (2005).

[60] Nicholls MA, Review of the Lubrication of Metallic Dialkyl-Dithiophosphates, Tribol. Intl, 38, pp. 15-39. 2005

[61] Thomas BC, Wear Modeling with Sensitivity to Lubricant Chemistry. Master of Science Thesis, Department of Mechanical Engineering, Massachusetts Institute of Technology, 2007.

[62] Keller J, Fridrici V, Kapsa P, Vidaller S, Huard JF, Influence of chemical composition and microstructure of gray cast iron on wear of heavy duty diesel engines cylinder liners. Wear 263; 2007: 1158-1164.

[63] Cousseau T, Serbino E, Rejowski E, Sinatora A, Influence of steadite on the tribological behavior of cylinder liners, Industrial Lubrication and Tribology, 2018

[64] Rounds FG, The Influence of Steel Composition on Additive Performance, ASLE Transactions, Vol. 15, 1972, pp. 54-66.

[65] Matveevsky RM, Sinaisky VM, Buyanovsky IA, Contribution to the Influence of Retained Austenite Content in Steels on the Temperature Stability of Boundary Lubricant Layers in Friction, Transactions ASME, Journal of Tribology, Vol. 97, 1975, pp. 512-515.

[66] Diergarten H, Stocker J, Werner H, Erfahrungen mit dem Vierkugelapparat zur Beurteilung von Schmierstoffen, Erdol und Kohle, Vol. 8, 1955, pp. 312-318.

[67] Kloos KH, Werkstoffpaarung und Gleitreibungsverhalten in Fertigung und Konstruktion, Fortschrittberichte der VDI Zeitschriften, Reihe 2, 1972, pp. 1-91.

[68] Begelinger A, De Gee AWJ, Salomon G, Failure of Thin Film Lubrication Function-Orientated Characterization of Additives and Steels, ASLE Transactions, Vol. 23, 1980, pp. 23-24.

[69] Gardos MN, The synergistic effect of graphite on the friction and wear of MoS2 films in air. Tribology Transactions, 31:2, 214-227: 2008.

[70] Yamamoto Y, Gondo S, Tanaka N, Effect of graphite on friction and wear characteristics of molybdenum dithiocarbamate. Tribology Letters, Vol. 17, No. 1, July 2004: 55-69. 
[71] Kubiak KJ, Mathia TG, Bigerelle M, Influence of roughness on ZDDP tribofilm formation in boundary lubricated fretting. Tribol. Mater. Surf. Interfaces 2012, 6, 182188.

[72] Zum Gahr K-H, Microstructure and Wear of Materials, Elsevier, Amsterdam, 1987.

[73] Lee PM, Chittenden R. Consideration of test parameters in reciprocating tribometers used to replicate ring-on-liner contact. Tribol Lett 2010; 39: 81-89.

[74] Czichos H, Habig K-H, Tribologie Handbuch, 2. Auflage, Friedr. Vieweg \& Sohn Verlag, Wiesbaden, 2003, ISBN 3-528-16354-2.

[75] Blau PJ, A Retrospective Survey of the Use of Laboratory Tests to Simulate Internal Combustion Engine Materials Tribology Problems, Tribology: Wear Test Selection for Design and Application, ASTM STP 1199, A. W. Ruff and R. G. Bayer, Ed., American Society for Testing and Materials, 1993.

[76] Blau PJ, A review of sub-scale test methods to evaluate the friction and wear of ring and liner materials for spark- and compression ignition engines, RNL/TM2001/184, 2001.

[77] Guesser WL, Propriedades mecânicas dos ferros fundidos. São Paulo: Blucher; 2009.

[78] Fredriksson H, Åkerlind U, Materials processing during casting, John Wiley \& Sons Inc, 2006.

[79] ASM Handbook Volume 15: Casting. ASM International, 2008.

[80] Rowe J, Advanced materials in automotive engineering. Cambridge: Woodhead Publishing Limited; 2012.

[81] Do Vale JL, Influência da Microestrutura de Ferros Fundidos na Ocorrência de Metal Dobrado e no Comportamento Tribológico de Superfícies Brunidas. Tese de Doutorado. Universidade Federal Tecnológica do Paraná, 2016.

[82] Callister WD, Materials Science and Engineering: An Introduction. 7. ed. New York: John Wiley \& Suns, 2007.

[83] Boff, CR, Metodologia de análise de blocos de motores: Aplicação a Blocos de Motores Diesel em Ferro Fundido Vermicular. Dissertação de mestrado Universidade Federal de Santa Catarina, 2003.

[84] Marquard R, Helfried S, McDonald M, Crack it up: New materials create new possibilities. Engine Technology International, 1998. 
[85] ASTM A48 / A48M. Standard Specification for Gray Iron Castings, 03(2016).

[86] Yamagata $\mathrm{H}$, The Science and Technology of Materials in Automotive Engines. Woodhead Publishing, Cambridge, pp. 18. 2005.

[87] Berns H, Theisen W, Ferrous Materials: Steels and Cast Iron, 1st ed., Springer, Berlin, Germany, 2008.

[88] Stefanescu DM, Alonso G, Larrañaga $P$, De la Fuente E, Suarez R, Reexamination of crystal growth theory of graphite in iron-carbon alloys. Acta Materialia. 139, 109-121 (2017).

[89] Stefanescu DM, Alonso G, Larranaga P, De la Fuente E, Suarez R, On the crystallization of graphite from liquid iron-carbon-silicon melts, Acta Mater. 107 (2016)

[90] Campbell J, Complete casting handbook, $2^{\mathrm{a}}$ edição. Elsevier, Oxford, 2015

[91] ASM. Speciality handbook: cast irons. Estados Unidos: ASM International, 1996.

[92] Wyckoff RWG, Crystal Structures, Interscience, New York 1, 1963.

[93] Double DD, Hellawell A, The nucleation and growth of graphite - the modification of cast iron, Acta Metall. Mater 43 (1995) 2435 - 2442.

[94] Roviglione AN, Hermida JD, From flake to nodular: a new theory of morphological modification in gray cast iron, Metall. Mater. Trans. 35B (2004) 313 330.

[95] Guesser WL, Cabezas CS, Guedes LC, Zanatta AM, High temperature strength of cast irons for cylinder heads, in Science and Processing of Cast Iron, Jönköping, Sweden, 2017.

[96] Riahi AR, Alpas AT, Wear map for grey cast iron. Wear 255, (2003), 401-409.

[97] Hase A, Visualization of the tribological behavior of graphite in cast iron by in situ observations of sliding interfaces. Tribology International 138, (2019), 40-46.

[98] Bevan JE, "Effect of Molybdenum on Dimensional Stability and Tensile Properties of Pearlitic Gray Irons at 600 to $850{ }^{\circ} \mathrm{F}\left(315\right.$ to $\left.455^{\circ} \mathrm{C}\right)$," internal report, Climax Molybdenum Company.

[99] Hrusovsky JP, Formation, Production and Properties of Compacted Graphite Iron, Ph.D. thesis, Case Western Reserve University, Cleveland, OH, 1982. 
[100] Ghasemi R, Elmquist L, A study on graphite extrusion phenomenon under the sliding wear response of cast iron using microindentation and microscratch techniques. Wear 320:120-126. 2014.

[101] Riahi AR, Alpas AT. Wear map for grey cast iron. Wear 255, (2003), 401-409.

[102] Rac, A, Influence of load and speed on wear characteristics of grey cast iron in dry sliding-selection for minimum wear. Tribol.Int.,IB (1985) 29-33.

[103] Cueva G, Tischiptschin AP, Sinatora A, Guesser WL, Desgaste de ferros fundidos usados em discos de freios de veículos automotores. $8^{\circ}$ Internacional Brake Colloquium. 2007:6.

[104] Standard Test Method for Evaluating the Microstructure of Graphite in Iron Castings, A 247, ASTM International.

[105] ASTM. ASTM E384-11e1 Standard Test Method for Knoop and Vickers Hardness of Materials. ed. ASTM International; 2012

[106] Tertuliano IS, Textura superficial: efeito sobre o desempenho de óleos aditivados e não aditivados em ensaios alternados. Dissertação. Universidade de São Paulo. 2017.

[107] Greenwood JA, Williamson JBP, Contact of Nominally Flat Surfaces. Proceedings of the Royal Society A: Mathematical, Physical and Engineering Sciences, v. 295, n. 1442, p. 300-319, 1966.

[108] Martin JM, Belin M, Mansot JL, Dexpert H, Lagarde P, Friction-Induced Amorphization with ZDDP - an EXAFS Study, ASLE Transactions, Vol. 29,1986, pp. 523-531.

[109] Profito, FJ, Modelagem Unidimensional Do Regime Misto De Lubrificação Aplicada a Superfícies Texturizadas. [s.I.] Dissertação de Mestrado em Engenharia Mecânica, Universidade de São Paulo, 2010.

[110] Dawson S, Hang F. Compacted graphite iron - a material solution for modern diesel engine cylinder blocks and heads. China Foundry. 2009;6(3):241-6.

[111] Sudarshan TS, Bhaduri SB. Wear in cylinder liners. Wear. 1983; 91(3): 269-79.

[112] Reich S, Thomsen C, and Maultzsch J. Carbon Nanotubes: Basic Concepts and Physical Properties, 2004.

[113] Tuinstra F, Koenig J. Raman spectrum of graphite. Journal of Chemical Physics, vol. 53, 1970. 
[114] Morina A, Neville A, Priest M, Green JH, ZDDP and MoDTC interactions and their effect on tribological performance - tribofilm characteristics and its evolution, Tribology Letters, Vol. 24, No. 3, Dezembro 2006.

[115] Topolovec-Miklozic K, Cann PM, Spikes HA, The use of AFM to study lubricant films. In: Franek, F., et al. (ed.) Plenary and Session Key Papers. 2nd WTC Conference, Vienna, 2001.

[116] Ye J, Kano M, Yasuda Y, Determination of nanostructures and mechanical properties on the surface of molybdenum dithiocarbamate and zinc dialkyldithiophosphate tribochemical reacted films using atomic force microscope phase imaging technique. J. Appl. Phys. 93, 5113-5117, 2003

[117] Ye J, Kano M, Yasuda Y, Evaluation of nanoscale friction depth distribution in ZDDP and MoDTC tribochemical reacted films using a nanoscratch method. Tribol. Lett. 16, 107-112, 2004 